TERTULLIAN AND THE BIBLE LANGUAGE - IMAGERY - EXEGESIS 

TERTULLIAN AND THE BIBLE 


\section{Promotor:}

Prof. Dr. Chr. A. E. M. Mohrmann 


\title{
TERTULLIAN AND THE BIBLE
}

\author{
Language, Imagery, Exegesis
}

\section{ACADEMTSCH PROEFSCHRIFT}

TER VERKRIJGING VAN DE GRAAD VAN DOCTOR IN DE LETTEREN AAN DE KATHOLIEKE UNIVERSITEIT TE NJMEGEN, OP GEZAG VAN DE RECTOR MAGNIFICUS DR. A. TH. L. M. MERTENS, HOOGLERAAR IN DE FACULTEIT DER GENEESKUNDE, VOLGENS BESLUIT VAN DE SENAAT IN HET OPENBAAR TE VERDEDIGEN OP VRIJDAG 6 OCTOBER 1967 DES NAMIDDAGS TE 2 UUR

DOOR

\section{T. P. O'MALLEY}

geboren te Milton, Massachusetts, U.S.A. 
AUGUSTINO ET ANNAE PARENTIBUS 


\section{CONTENTS}

Abbreviations . . . . . . . . . . . . . . . . . VII

Texts, Editions. Note . . . . . . . . . . . . . . . . vIII

Concordances. Dictionaries . . . . . . . . . . . . . IX

Bibliography . . . . . . . . . . . . . . . . . . . . XI

Chapter One

The Problem of Biblical Language

Introduction . . . . . . . . . . . . . . . . . 1

The context of Tertullian . . . . . . . . . . . . 2

A brief review of opinions . . . . . . . . . . . . . . . 7

Texts unaffected by the adu. Marcionem polemic . . . . . . 8

Non-glossing texts. . . . . . . . . . . . . . . 8

Glossing texts . . . . . . . . . . . . . . . . 14

Some glosses of terms in Tertullian . . . . . . . . . 26

Texts from the adu. Marcionem . . . . . . . . . . . . . 37

Conclusion. . . . . . . . . . . . . . . . . . . 62

Chapter Two

IMAGERY

Introduction . . . . . . . . . . . . . . . . 64

Vegetation . . . . . . . . . . . . . . . . 68

The sea. Water and the Spirit . . . . . . . . . . 74

Bestiary themes . . . . . . . . . . . . . . 82

Clothing . . . . . . . . . . . . . . . . . . 89

Medicine . . . . . . . . . . . . . . . . 98

Arms and Athletics . . . . . . . . . . . . . . 107

Controversy as combat . . . . . . . . . . . . 108

Arms and military life . . . . . . . . . . . . . 109

Athletics and the martyr . . . . . . . . . . . . 112

The plastic view of creation . . . . . . . . . . . 113

Conclusion. . . . . . . . . . . . . . . . . 115

Chapter Three

EXEGESIS AND ITS VOcabulary

Introduction . . . . . . . . . . . . . . . . . 117

aenigma .. . . . . . . . . . . . . . . 141

allegoria . . . . . . . . . . . . . . . . . 145

figura . . . . . . . . . . . . . . . . . . 158

portendere. . . . . . . . . . . . . . . . . . . 164 
simplicitas ................ 166

Conclusion. . . . . . . . . . . . . . . . 172

Conclusion . . . . . . . . . . . . . . . . . 173

Index of important biblical texts . . . . . . . . . . 180

Index of important texts in Tertullian . . . . . . . . . 181

Index of Latin words . . . . . . . . . . . . 183 


\section{ABBREVIATIONS USED}

ACW Ancient Christian Writers, Westminster, London, $1946 \mathrm{ff}$.

CC Corpus Christianorum, series latina, Turnholti, $1953 \mathrm{ff}$.

CSEL Corpus Scriptorum Ecclesiasticorum Latinorum, Vindobonae, $1866 \mathrm{ff}$.

ELC Christine Mohrmann, Etudes sur le latin des chrétiens, $\mathbf{I}^{2}$ Rome, 1961; II, Rome, 1961; III, Rome, 1965.

GCP Graecitas Christianorum Primaeda, Nijmegen, $1962 \mathrm{ff}$.

GCS Die griechischen christlichen Schriftsteller, Berlin, $1897 \mathrm{ff}$.

JTS The Journal of Theological Studies, London, $1899 \mathrm{ff}$.

LCP Latinitas Christianorum Primaeva, Nijmegen, 1932 ff.

PG Patrologiae cursus completus, series graeca, accurante J.-P. MigNE, Lutetiae Parisiorum, $1857 \mathrm{ff}$.

PL Patrologiae cursus completus, series latina, accurante J.-P. MigNE, Lutetiae Parisiorum, 1844 ff.

SbDAWB Sitzungsberichte der königlichen preussischen Akademie zu Berlin, histor.-philosoph. Klasse.

ThLL Thesaurus Linguae Latinae, Lipsiae, $1900 \mathrm{ff}$.

TU Texte und Untersuchungen, Berlin, Leipzig, $1882 \mathrm{ff}$.

TWzNT Theologisches Wörterbuch zum Neuen Testament, Stuttgart, $1933 \mathrm{ff}$.

VC Vigiliae Christianae, Amsterdam, $1947 \mathrm{ff}$.

VL Vetus Latina. Die Reste der altlateinischen Bibel, nach Petrus Sabatier neu gesammelt und herausgegeben von der Erzabtei Beuron, Freiburg, $1949 \mathrm{ff}$.

ZNTW Zeitschrift fuir die neutestamentliche Wissenschaft und die Kunde der älteren Kirche, Giessen, Berlin, $1900 \mathrm{ff}$. 


\section{TEXTS, EDITIONS}

Bonifatius Fischer, Vetus Latina. Die Reste der altlateinischen Bibel, nach

Petrus Sabatier neu gesammelt und herausgegeben von der Erzablei Beuron, Freiburg, $1949 \mathrm{ff}$.

Adolf Jülicher, Walter Matzkow, Kurt Aland, Das Neue Testament in altlateinischer Uberlieferung, Berlin, 1938-1963.

Egerhard Nestle, Erwin Nestle and Kurt Aland, Novum Testamentum Graece et Latine, Stuttgart, $1963^{22}$.

KURT ALAND: Synopsis Quattuor Evangeliorum, locis parallelis apocryphorum et patrum adhibitis edidit, Stuttgart, 1964.

Alfred Rahlfs, Septuaginta, II Vols., Stuttgart, 1962?.

Tertullian: all citations from Tertullian are made according to the editions collected in: Corpus Christianorum, series latina, Vols. I and II, Turnholti, 1954.

For citations made from later Fathers, the name of the editor, and the volume, page and line reference in series of respective editions is given.

Note: I express my indebtedness to Dom Bonifatius Fischer, of the Vetus Latine Institute, and to Dr. Ehlers, director of the Thesaurus Linguae Latinae, and to their respective collaborators at Beuron and Munich, for the use of their facilities and for their invaluable assistance. 


\section{CONCORDANCES, etc.}

Hatch, E., Redpath, H., A Concordance to the Septuagint and the other

Greek Versions of the Old Testament, II Vols., Oxford, 1897.

Moulton, W. F., Geden, A. S., A Concordance to the Greek Testament, Edinburgh, 19634.

Dutripon, F. P., Vulgatae Editionis Biblionum Sacrorum Concordantiae, Lutetiae Parisiorum, no date.

Goodspeed, Edgar J., Index Patristicus, Leipzig, 1907.

- Index Apologeticus, Leipzig, 1912.

REYNDERs, B., Lexique comparé du texte grec, et des versions latine, arménienne, et syriaque de l'Adv. Haereses de Saint Irénée, II Vols., Louvain, 1954.

Henen, P., Index verborum quae Tertulliani Apologetico continentur, Leuven, 1910.

Michiels, A., Index verborum omnium quae sunt in $Q$. Septimii Florentis Tertulliani tractatu De praescriptione haereticorum, addita lucubratione de praepositionibus in tractatu De praescriptione haereticorum occurrentibus, (Instrumenta Patristica 1), Steenbrugge, 1959.

Borleffs, J. W. Ph., in his edition: Tertulliani Ad Nationes libri duo, Leiden, 1929, 92-155.

- Index verborum quae Tertulliani De Baptismo libello continentur, Mnemosyne II 59 (1931), 50-102.

- Index Verborum quae Tertulliani De Paenitentia libello continentur, Mnemosyne, II 60 (1932), 274-316.

Waszink, J. H., Index verborum et locutionum quae Tertulliani De Anima libro continentur. Accedunt addenda et corrigenda ad editionem libri eiusdem, Bonn, 1935.

Thierry, J. J., in his edition: Tertullianus, De Fuga in Persecutione, met inleiding, vertaling, toelichting en index, Hilversum, 1941, 233-262.

\section{DICTIONARIES}

Charlton T. Lewts and Gharles Short, A Latin Dictionary. founded on Freund's Latin Dictionary, Oxford, 1879; 1962.

W. F. Arndt and F. W. Gingrich, A Greek-English Lexicon of the Nerw Testament and other early Christian Literature, translated and edited from W. BAUER, Griechisch-deutsches Wörterbuch zu den Schriften des 
Neuen Testaments und der ïbrigen urchristlichen Literatur, 1949-524, Chicago, Cambridge, 1957.

Albert Blaise, Dictionnaire latin-français des auteurs chrétiens, revu spécialement pour le vocabulaire théologique par HeNRI GHIRAT, Strasbourg 1954; with addenda and corrigenda, Turnhout, 1962.

G. W. H. Lampe, A Patristic Greek Lexicon, Oxford, $1961 \mathrm{ff}$. 


\section{BIBLIOGRAPHY}

Aalders, G. J. D., Tertullianus' citaten uit de Evangelien en de oud-Latijnse Bijbelvertalingen, Amsterdam, 1932.

—_, Tertullion's Quotations from St. Luke, Mnemosyne III, 5 (1937), 241-282.

D'Alès, Adhémar, La théologie de Tertullien (Bibliothèque de théologie historique), Paris, 1905.

- Tertullianea. Le rhinocéros et le symbolisme de la croix, Recherches de science religieuse 20 (1936), 99-100.

- Tertullien, symbolum, Recherches de science religieuse 20 (1936), 468.

Altaner, Berthold, Paganus. Eine bedeutungsgeschichtliche Untersuchung, Zeitschrift für Kirchengeschichte 58 (1939), 130-141.

Antin, Paur, 'Simple' et 'simplicite' chez saint Jérôme, Revue Bénédictine 71 (1961), 371-381.

Arbesmann, Rudolph, The Concept of 'Christus medicus' in St. Augustine, Traditio 10 (1954), 1-2B.

—, Christus medicus humilis in St. Augustine, Augustinus Magister (Congrès international Augustinien), Paris, 1954, Vol. II, 623-629.

Armstrong, Gregory T., Die Genesis in der alten Kitche. Die drei Kirchenväter (Beiträge zur Geschichte der biblischen Hermeneutik, no. 4), Túbingen, 1962.

Audet, Jean-Paul, L'hypothèse des testimonia. Remarques aulour d'un livre récent, Revue biblique 70 (1963), $381-405$.

Aurrbach, Eruch, Figura, Archivum Romanicum 22 (1938), 436-489.

DE BAGKer, E., Sacramentum, le mot et l'idée dans Tertullien, Louvain, 1911.

Bardy, Gustave, La latinisation de l'église d'Occident, Irenikon 14 (1937), 3-20; 113-130.

_. La question des langues dans l'eglise ancienne, Paris, 1948, Vol. I.

_. Exégèse patristique, Dictionnaire de la Bible, Supplément 4 (1949), $569 \mathrm{ff}$.

BarLow, R. M., Biblical Inspiration in Tertullian, The Theologian, (Woodstock) 13.2 (1957), 40-44.

Baugr, Johannes B., Drei cruces, Biblische Zeitschrift, neue Folge 9 (1965), 84-91.

Beck, A., Der Einfluss der römischen Rechlslehre auf die Formulierung des Katholischen Dogmas bei Tertullian, Heidelberg, 1923.

-, Römisches Recht bei Tertullian und Cyprian. Eine Studie zur frühen Kirchenrechtsgeschichte (Schriften der Königsberger gelehrten Gesellschaft 7.2), Halle, I930.

Becker, Card, Tettullians Apologeticum, Werden und Leistung, München, 1954.

Bender, Wolfgang, Die Lehre über den heiligen Geist bei Tertullian (Münchener theologische Studien 1.18), München, 1961.

Blackman, E., Marcion and his Influence, London, 1948.

Blatt, Franz, Remarques sur l'hisloire des traductions latines, Classica et Mediaevalia 1 (1938), 217-242.

Boman, Thorleif, Das hebräische Denken im Vergleich mit dem Griechischen, 2. durchgesehene Auflage, Göttingen, 1954.

Boschi, P., Un vecchio simbolo della nostra resurrezione, La Civiltà Cattolica 99, II (1948), 19-28.

Botte, Bernard, Itala, Dictionnaire de la Bible, Supplément 4 (1949), cols. 777-782.

$\longrightarrow$, (Versions) latines antérieures à $S$. Jtốme, Dictionnaire de la Bible, Supplément 5 (1957), cols. 334-347.

Braun, Rent, Deus Christianonum. Recherches sur le oocabulaire doctrinal de Tertulliem, Paris, 1962. 
Bulhart, Vincenz, Tettullian-Studien, Österreichische Akademie der Wissenschaften, Philosophisch-historische Klasse, Sitzungsberichte, 231, Band 5, Wien, 1957.

Burgos, Tomas, Concepto de 'sacramentum' en Tertuliano, Helmantica 10 (1959), 227-256 Burkitt, F. C., The Old Latin and the Itala (Texts and Studies 4.3), Cambridge, 1896. Burton, ERnest De WitT, The Epistle to the Galatians (International Critical Commentary), Edinburgh, 1921.

Cadbury, Henry J., The Making of Luke-Acts, New York, 1928; London, 1958.

von Campenhausen, H., Tradition und Geist im Urchristentum, Studium Generale 4 (1951), 351-357.

Cantalamessa, Raniero, La Cristologia di Tettulliano (Paradosis 18), Friburgo, 1962.

Capelle, Paul, Le texte du Psautier latin en Afrique (Collectanea biblica latina 4), Rome, 1913.

Cochrane, Charles N., Christianity and Classical Cultute, Oxford, 1940; New York, 1957.

Colson, F. H., Two Examples of Literary and Rhetorical Criticism in the Fathers, The Journal of Theological Studies 25 (1924), 364-377.

Gurtius, Ernst Robert, European Literature and the Latin Middle Ages, (English translation of Europäische Literatur und lateinisches Mittelalter, Bern, 1948), New York, $1953 ; 1963$.

Dantélou, Jean, Les divers sens de l'Écriture dans la tradition chretienne primitive, Ephemerides theologicae Lovanienses 24 (1948), 119-126.

—-, Sacramentum Futuri. Etudes sur les origines de la typologie biblique, Paris, 1950.

- Les symboles chretiens primitifs, Paris, 1961.

- Die Kirche: Pflanzung des Vaters. Zur Kirchenfrömmigkeit der frühen Christenheit, in: Sentire Ecclesiam (Festschrift Hugo Rahner), herausgegeben von JEan Danit́lou, Herbert Vorgrimler, Freiburg, Basel, Wien, 1961; 92-100.

—, Eludes d'exégèse judéo-chrétienne (Les testimonia), Paris, 1966.

Daube, David, Two Haggadic Principles and the Gospels, The Journal of Theological Studies 44 (1943), 149-155.

Derkers, E., Tertullianus en de geschiedenis der liturgie, (Catholica VI. 2), Brussel, Amsterdam, 1947.

DEN BOER, W., De allegorese in het werk van Clemens Alexandrinus, Leiden, 1940.

-, Hermeneutic Problems in Early Christianity, Vigiliae Christianae 1 (1947), 150-167.

Demougeot, E., 'Paganus', Mithre et Tertullien, Studia Patristica, Vol. III (Oxford Patristic Congress, 1959) Texte und Untersuchungen 78; 354-365.

DE VRTEs, G. J., Bijdrage tot de psychologie van Tertullianus, Utrecht, 1929.

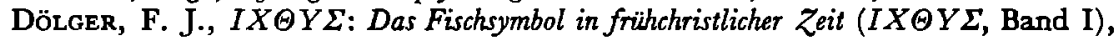
Rome, 1910.

- Der heilige Fisch in den antiken Religionen und im Christentum ( $I X \Theta Y \Sigma$, Band II), Münster, 1922.

- Sol Salutis ${ }^{2}$, Münster, 1925.

Eijkenвoom, P. C. J., Het Christus-medicusmotief in de preken van sint Augustinzs, Assen, 1960.

Evans, E., Tertullian's Commentary on the Marcionite Gospel, Studia Evangelica (Oxford Congress, The Four Gospels in 1957), Texte und Untersuchungen 73, Berlin, $1959 ; 699-705$.

- Q. Septimii Florentis Tertulliani de resurrectione camis liber, London, 1960.

da Fabriano, Germano, La chiusuta della rivelazione in Tertulliano, Studia Patavina 5 (1958), 171-193.

Fanon, G., Tertulliano interprete delle profezie messianiche, Rome, 1957.

Fischer, Balthasar, 'Conculcabis leonem et draconem'. Eine deutungsgeschichtliche Studie zur Verwendung von Psalm 90 in der Quadragesima, Zeitschrift für Katholische Theologie 80 (1958), 421-429.

Flessman-van Leer, E., Tradition and Scripture in the Early Church, Assen, 1953. 
Ford, J. Massingeerd, The Meaning of 'Virgin', New Testament Studies, 12 (1965-66), 293-299.

Freedman, J. H., Midrash Rabba, translated under the editorship of Rabbi Dr. J. H. Freedman and Maurice Somon, X Vols., London, 1951.

De Ghellinck, J., et al., Pour l'histoire du mot sacramentum, (Spicilegium sacrum Lovaniense 3), Vols. I: les anténicéens, Louvain, i9-24.

Glaue, P., Die Vorlesung heiliger Schriften bei Tertullian, Zeitschrift für die neutestamentliche Wissenschaft 22-23 (1923-24), 141-152.

Goldammer, K., Das Schiff der Kirche, ein antiker Symbolbegriff aus der politischen Metaphorik in eschatologischer und ekklesiologischer Umdeutung, Theologische Zeitschrift 6 (1950), 232-237.

Grant, Robert M., Tatian and the Bible, Studia Patristica, Vol. I (Oxford Patristic Congress, 1955) Texte und Untersuchungen 63, 297-306. , The Letter and the Spirit, London, 1957.

Greenslade, S. L., Scripture and Other Doctrinal Norms in early Theories of the Ministry, The Journal of Theological Studies, 44 (1943), 162-176.

Haegglund, B., Die Bedeutung der 'regula fidei' als Grundlage theologischer Aussagen, Studia Theologica 12 (1958), 1-44.

Hanson, R. P. C., Allegory and Event, London, 1959.

- Notes on Tertullien's Interpretation of Scripture, The Journal of Theological Studies, n.s. 12 (1961), 273-279.

(von) Harnack, Adolp, Medicinisches aus der ältesten Kirche (Texte und Untersuchungen VIII. 4), Leipzig, 1892.

-, Militia Christi, Tubingen, 1905.

- Tertullians Bibliothek christlicher Schriften, Sitzungsberichte der königlichen preussischen Akademie der Wissenschaften zu Berlin, histor.-philosoph. Klasse, $1914,303-314$.

- Marcion : das Evangelium vom fremden Gott. (Texte und Untersuchungen, 3 Reihe, 15 Band, no. 45), Leipzig, 19242.

- Geschichte der altchristlichen Literatur bis Eusebius (rv Vols.), Leipzig, 1958².

Heinisch, Paul, Der Einfluss Philos auf die älteste christliche Exegese, (Alttestamentliche Abhandlungen, Heft 1/2), Munster i. W., 1908.

Herescu, Nicola I., Un theme traditionnel de la poésie latine : le naufrage, Rivista Clasica 4 (1932-33), 119-137.

Hrgarss, A. J. B., The Latin Text of Luke in Marcion and Tertullian, Vigiliae Christianae 5 (1951), 1-42.

Hodnetr, Mona P., The Sea in Roman Poetry, The Classical Journal, 15 (1919-1920), $67-82$.

Hold, KarL, Tertullian als Schriftsteller, Gesammelte Aufsätze zur Kirchengeschichte (III Vols.), Tübingen, 1923; Vol. III, 1-12.

Hoppe, Heinruch, Syntax und Stil des Tertullian, Leipzig, 1903.

Hoppensrourwers, H. A. M., Recherches sur la terminologie du martyre de Tertullien à Lactance (Latinitas Christianorum Primaeva 15), Nijmegen, 1961.

Hubaux, Jean, and Leroy, Maxime, Le mythe du phénix dans les littératures grecque et latine (Bibliothèque de la Faculté de Philosophie et Lettres de l'Université de Liège, fasc. LXXXII), Paris, Liège, 1939.

Huxley, H. H., The Perils and Penalties of Seafaring: a Stock Theme in Latin Poetry, Proceedings of the Leeds Philosophical and Literary Society, lit. and hist. sect., 6, 8 (1951), 576-582.

Janssen, Harry, Kultur und Sprache. Zur Geschichte der alten Kirche im Spiegel der Sprachentwicklung (Latinitas Christianorum Primaeva 8), Nijmegen, 1938.

Karpp, Heinruch, Probleme altchristlicher Anthropologie (Beiträge zur Förderung christlicher Theologie 44. 3), Gütersloh, 1950.

_, Schrift und Geist bei Tertullian, Gütersloh, 1955. 
Keller, OTto, Die antike Tretwelt, II Vols., Leipzig, 1909.

Kellner, A. H., and Esser, Gerraro, Tertullians Aurgewahlte Schriften (Bibliothek der Kirchenvater), Kempten, Munchen, 1915.

Kulpatruck, G. D., I Tim. V. 22 and Tertullian De Baptismo XVIII.I, The Journal of Theological Studies, n.s. 16 (1965), 127-128.

Klauser, TheOdor, Der Uebetgang der römuschen Kutche von der grzechischen zur lateinischen Liturgiesprache, Miscellanea Mercatı (Studi e testi, 121-127), Rome, Città del Vaticano, 1946; Vol. I, 467-482.

Knaake, J. A., Die Predigten des Tertullian und Cyprian, Theologische Studien und Kritiken 76 (1903), 606-639.

Knox, John, Marcion and the New Testament, Chicago, 1942.

Косн, Hugo, Tertullianusches IV. 8. Due Fergenblatter der Stammeltern bet Irenaus und bet Terlulluan und die Nachwrrkung threr Erklarungen, Theologische Studien und Kritiken 104 (1932), 39-50.

Kolping, Adolf, Sacramentum Tertullaneum, Munster, 1948.

Kuss, Oтto, Zur Hermeneutzk Tertullians, Neutestamentlzche Aufsatze (Festschrift fur Prof. Jasef Schmid zum 70. Geburtstag), ed. J. Blinzer et al., Regensburg, 1963; p. 138-160.

LabhardT, ANDRE, Tertullien et la phllosophie ou la recherche d'une postition pure, Museum Helveticum 7 (1950), 159-180.

de Labriolle, Pierre, Tettullien: de paenilentia, de puduitia, Paris, 1906.

- Tertullzen a-t-il connu une verszon latıne de la Bible?, Bulletin d'ancienne littérature et d'archéologie chrétiennes 4 (1914), 210-213.

- Hislore de la litterature latine chretzenne, 3rd edition, revised, and added to by Gustave Bardy, II Vols., Paris, 1947.

_- La physzologie dans l'oevore de Tertullıen, Archives générales de médecine 83 (1906), 1317-1328.

Le Saint, William P., Tertullian: Treatises on Penance. On Penance and on Purty (Ancient Christian Writers 28), Westminster, London, 1959.

LOEWE, R., The Jewnsh Mudrashim and Patristzc and Scholastic Exegesis of the Bible, Studia Patrustica, Vol. I (Texte und Untersuchungen 63), Berlin, 1957, p. 492-514.

LoRTz, J., Vernunft und Offenbarung ber Tertullian, Der Katholik 93 (1913), 124-140.

DE Lubac, Henri, Histoure et Esprit, L'intelligence de l'Ecriture d'après Origène (Théologie 16), Paris, 1950.

, A propos de l'allégorze chrétienne, Recherches de science religieuse 47 (1959), 5-43.

_- Exégese médrévale: les quatre sens de l'Ecrnture, (Théologie, 41, 42, 59), Paris, $1959-1963$.

Luiselli, Bruno, Il Codex Trecensis 523 e alcune citaziont sctitturali nel de baptismo Tertullzaneo, Rivista di Cultura Classica e Medioevale 2 (1960), 209-213.

Malone, Edward E., The Monk and the Martyr (Studies in Christian Antiquity 12), Washington, 1950.

Matzkow, Walter, De uocabulis quibusdam Italae et Vulgatae Christranis, Berlin, 1933.

van der Meer, F., and Mohrmann, Christine, Atlas of the Ancient Chtistzan World (English translation of Atlas van de oudchrustelijke wereld, Amsterdam, 1958), London and Edinburgh, 1958.

Mrershoex, G. Q. A., Le latin biblzque d'apres saint fétóme (Latinitas Christianorum Primaeva 20), Nijmegen, 1966.

MeYboom, H. U., Marcion en de Marcionieten, Leiden, 1888.

Mohrmann, Christine, Die altchristliche Sondersprache in den Sermones des hl. Augustin (Latinitas Christianorum Primaeva 3), Nijmegen, 1932; reimpression with Nachtrag, Amsterdam, 1965.

Tertulluanus: Apologeticum en andere geschriften uit Tertullianus' Voor-Montanistischen tijd (Monumenta Christiana 1. 3), Utrecht en Brussel, 1951. , Études sur le latzn des chretiens $I^{2}$, Rome, 1961. 
Etudes sur le latin des chrétıens II, Latın chrétren et médréval, Rome, 1961.

_- Etudes sur le latin des chretzens III. Latzn chrétzen et liturgique, Rome, 1965.

Moingt, Joseph, Théologue trinitaire de Tertullzen (Théologie 68, 69, 70, 00), Parns, 1966.

Monceaux, Paul, Hustoire litléraite de l'Afrique chrétzeñze, Pans, 1901; Impression anastatique, Bruxelles, 1963, Vol. I.

Morel, V., Deductor omnis ueritatis. Het vers $70.16,19$ by Tertullzanus, Studia Catholica $16(1940), 194-206$.

_-, Dusciplina: le mot et l'zdée représentée par lur dans les oeuvres de Tertullien, Revue d'Histoire Ecclésiastique 40 (1944-45), 5-46

-, De ontwikkeling van de chrssteligke overlevering volgens Tertullianus (Catholica I. 2), Brugge, 1946.

Musurillo, Herbert, Symbolusm and the Christran Imagination, Baltimore, 1962.

Neander, August, Antzgnostikus: Geist des Tertullzans, Berlın, $1849^{2}$.

OтT, J., Due Bezerchnung Chrzsti als lazoós in der urchrzstlichen Literatur, Der Katholik 90 (1910), 454-458.

De Pauw, Frans, La justification des traditions non écntes chez Tertullien, Ephemendes Theologicae Lovanienses 19 (1942), 5-46.

Pépin, JeAn, A propos de l'hastonte de l'exégèse allegonque: l'absurduté, stgne de l'allegarre, Studia Patrustica I (Oxford Patristic Congress, 1955), Texte und Untersuchungen 63, 395-413.

—_, Mythe et allegorie. Les ongines grecques et les contestations judé-chrétzennes, Paris, 1958.

Peterson, Erik, Das Schaff als Symbol der Kirche $\cdot$ dre Tat des Messzas im eschatologischen Meeressturm in der judischen und altchristlichen Ueberlizeferung, Theologische Zeitschruft 6 (1950), 77-79.

Pétré, Hét.̀̀ne, L'exemplum chez Tertullen, Neuilly-sur-Seine, undated.

Piesik, Helnz, Bildersprache der apostolzschen Vater, Bonn, 1961.

Poschl, Viktor, Gartner, Helga, and Heyke, W altraut, Biblrographre zut antzken Bildersprache (Bibliothek der klassischen Altertumswissenschaft, neue Folge, 1 Reihe), Herdelberg, 1964.

Poschmann, Bernhard, Paententia secunda, Bonn, 1940; reimpression, 1964.

Prestige, G. L., God in Patrustic Thought, London, 1936, 1959.

Quasten, Johannes, Patrology, Utrecht, Antwerpen I33, 1962; II'2, 1962; III, 1960. QuisPel, Gilles, De bronnen van Tertullzanus' Adversus Marconem, Leiden, 1943.

-, Anima naturaliter christiana, Eranos Jahrbuch 18 (1950), 173-182.

- Het geturgenzs der zzel bij Tertullianus, Le1den, 1952.

Restrepo-Jaramillo, J., Tertuliano y la doble formula en al simbolo apostolzco, Gregorianum 15 (1934), 3-58.

Refoulf, F., Tertullien et la phalosophre, Revue des sciences religieuses 30 (1956), 42-45.

Rerjners, G. Q., The Terminology of the Holy Cross in Early Christian Literature (Graecitas Christıanorum Primaeva 2), Nijmegen, 1965.

Rheinfelder, Hans, Confiten, confessio, confessor im Kirchenlatein und in den romanischen Sprachen, Die Sprache 1 (1949), 56-57.

Rivet, Dense, Tertullzen et l'Écriture (diplôme soutenu en 1958 à la Faculté des Lettres de Lyon).

Rahner, Hugo, Gruechische Mythen in christlicher Deutung, Zurich, 1966³.

- Symbole der Kirche: due Ekklesiologie der Vater, Salzburg, 1964.

Roberts, Alexander, The Ante-Nicene Fathers, XV Vols., Edinburgh, New York, $1902-1905$.

Robertson, Robert G., The Theology of Tetullian, London, 1924

Ronsch, Hermann, Das newe Testament Tertullian's, Leipzig, 1871.

- Itala und Vulgata. Das Sprachzdiom der urchrustluchen Itala und der katholeschen Vulgata, unter Berücksuchtıgung der rōmuschen Volkssprache, Marburg, 1875². 
Rossi, Santo, La catazione dez testi sacn nell' Adversus Praxean di Tertulliano, Giomale Italiano di Filologia 13 (1960), 249-260.

Saflund, Gosta, De Pallio und dre stilistzsche Entwicklung Tertullians (Skrifta Utgivna av Svenska Institutet i Rom $8^{\circ}$, viii) Lund, 1955.

DE SAInt-Denis, E., Le róle de la met dans la poésze latine, Lyon, 1935.

Sanday, W., Turner, C. H., and Souter, A., Noutm Testamentum S. Irenaer Eprscopt Lugdunensis, Oxford, 1923.

Schlier, Heinrich, Der Brief an die Galater (Meyers Kommentar VII), Gottingen, 1962.

Schulte, F. W. C. L., Het hezdendom by Tertullzanus, Nykerk, 1923.

Shotweld, Willis, The Biblical Exegeses of Justin Martyr, London, 1965.

von Soden, H., Das lateinusche Neue Testament in Afrika zur Zeit Cyprzans, Leipzig, 1909.

- A. von Harnacks Marcion, Zeitschnft fur Kirchengeschichte 40 (1922), 191-206.

-, Der latennsche Paulustext ber Marczon und Tertullzan, Festgabe A. Julucher, Tubingen, 1927, 229-281. Also separately published, Tubingen, 1927.

Spurgeon, Caroline, Shakespeare's Imagery and What it Tells $U s$, London, New York, $1935 ; 1965$.

Stenzel, Meinrad, Zur Fruhgeschichte der latemuschen Bibel, Theologische Revue 49 (1953), 97-103.

Straub, Werner, Die Bildersprache des Apostels Paulus, Tubingen, 1937.

Stummer, Friedrich, Einfuhrung in die lateinische Bibel, Paderborn, 1928.

Theuwen, S. W. J., Sprachlicher Bedeutungswandel bet Tertullaan (Studien zur Geschichte und Kultur des Altertums 14. 1), Paderborn, 1926.

Tibilettr, C., Il crestrano e la Scrittura in un passo de Tertullano, Giornale Italiano Filologico 15 (1962), 254-256.

Trankle, Hermann, Q.S. F. Tertulluan advetsus Iudaeos, Wiesbaden, 1964.

VAcCari, Alberto, Sintti di Enudizione e di Filologia, Rome, 1958.

Velisico, A., La Rzvelazione e le sue fonti nel De praescriptione haeretzcorum di Tertulliano (Lateranum, nova serie 1.4), Rome, 1935.

Verhoeven, Th. L., Studiēn over Tertullanus' Adversus Praxean, Amsterdam, 1948.

Vogels, H., Untersuchungen zur Geschichte der laternuschen Apocalypse-Übersetzung, Dusseldorf, 1920.

-, Lateinusche Bibelubersetzungen, Lexicon fur Theologie und Kirche' ${ }^{1}$, I, cols. 303-307.

Waltzing, J. P., Tettullien: Apologétzque, Paris, 1931.

Waszink, J. H., Q.S. Fl. Tertulluan De Anzma, Amsterdam, 1947.

-, Tertulluan: The Treatzse Against Hermogenes (Ancient Christian Writers 24), Westmunster, 1956.

Werss, Meĩr, Methodologisches über die Behandlung der Metapher, Theologische Zeitschrift 23 (1967), 1-25.

Wellek, René and Warren, Austin, Theory of Ltterature, New York, 1948.

Wheelwright, Philip, The Burning Fountain, Bloomington, 1954.

WhITE, T. H., The Bestrary, New York, 1954, 1960.

ZahN, Theodor, Geschichte des neutestamentlzchen Kanons, Vol. I, Erlangen, 1888.

Ziegler, Joseph, Ezechiel (Vetus Testamentum Graecum, auctoritate Societatis Litterarum Gottingensis XVI, pars 1), Gottingen, 1952.

Zimmermans, Gottpred, Die hermeneutischen Prinzipuen Tertullians, Wurzburg, 1937. 


\section{THE PROBLEM OF BIBLICAL LANGUAGE}

\section{INTRODUCTION}

The message of salvation, first set in a given language and culture, 、 requires constant re-interpretation, new heralding in word and gesture, as it passes from its original milieu to new lands and new languages. As with the imperium, and studium, there is a translatio euangelii, a passage, ideally, to every culture. The effort to clothe the scriptures in Latin was enormously to affect the culture of the West.

We have come to appreciate the role of St. Jerome in this process. He appears more and more as the revisor, the correcting editor, rather than the translator who would have made a complete new version. ${ }^{1}$ We have come, too, to appreciate the complexity of that body of translations which existed before him, which the Thesaurus Linguae Latinae, dependent on an older terminology, calls the Itala, and which now we rather group under the heading of Vetus Latina. There have been efforts to compartmentalise the hesitancies and preferences in vocabulary into 'African' and 'European' traditions. Classic examples of these regional differences are: sermo/uerbum, tinguere/baptizare, claritas/ gloria, felix/beatus, saeculum/mundus, etc. There are also differences of basic text. The LXX version, over against Theodotion's translation, for example, of the Old Testament ${ }^{2}$; in the New, differences which result from varying traditions and readings of the Greek New Testament, and from conflation of synoptic texts. This tradition of Latin biblical translations which predate Jerome is richer for some books of the Bible than for others. The Psalms, for example, with their pride of place in Christian worship, and the Gospels, of course, are far better represented than other books. A glance at the material gathered at the Archabbey of Beuron shows how rich and intricate is this tradition.

At 250 A.D., we are already well into the tradition of Latin biblical

1 See: G. Q.A. Meershoek, Le latin biblique d'après saint Jérôme (LCP 20), Nijmegen, 1966, passim.

See: F. C. Burkrtr, The Old Latin and the Itala (Texts and Studies 4.3), Cambridge, 1896, p. 18-31. 
translations. Gyprian in Africa, Novatian in Rome are both citing well-established Latin translations of parts of the Scripture, and in a consistent way. We may be sure that translations existed and had authority in the local churches. Tertullian, however, is a very different case. His very numerous citations of, and allusions to the scriptures show a great freedom and variety. The canon of the scriptures is still not sharply defined.

The freedom with which one may or may not cite the scriptures is closely related to the attitude toward Scripture itself. ${ }^{1}$

\section{The Context of Tertullian}

Tertullian is profoundly familiar with the Bible. Not alone citations, but allusions saturate his text. To take but one book of the Bible: Matthew citations and allusions appear in every one of his works, de pallio alone excepted. The references vary, naturally, according to the nature of the work and its audience; ad nationes, apologeticum, ad Scapulam offer but sparse allusions, while the other works are richer. With all the freedom with which Tertullian makes his citations, the very bulk of them leads one to suspect that he is not always the active translator. It is of considerable interest to know what Tertullian owed to the work of translation in the church of his time and area, and what is due to his innovation, in order to place him more accurately in the development of Christian Latin. It is vain to suppose that this can ever be done with any great accuracy; the evidence is simply insufficient.

Various efforts have been made to pinpoint the beginnings of Latin translation activities in Africa. The Acta of the martyrs of Scilli, at 180 A.D., written in Latin, seem to suggest that the martyrs had in their possession the Epistles of Paul, and, in all probability, the Gospels. Arguments have been made that the social condition of the martyrs make it highly improbable that these texts were still in Greek. This is a not unreasonable conclusion; but it takes its full value only when placed in the full context of what we know of the church in North Africa. Tertullian did not suddenly spring to life there as the first Latin writer among the Christians, and as the creator of the Latin of the Christians. ${ }^{2}$ The church in Africa was, from the very beginning, at

1 Paul Capelie, Le texte du Psautier latin en Afrique (Collectanea biblica latina 4) Rome, 1913, p. 19.

2 See: Christine Mohrmann, Tettullianus: Apologeticum en andere geschriften (Monumenta Christiana 1.3) Utrecht en Brussel, 1951, p. Koxovi-looxvii; Observations sur la langue et le style de Tertullien, Nuovo Didaskaleion IV (1950), p. 41-54 (= ELC. II, p. 235-246). 
least bilingual, and a Latin liturgy probably developed earlier in Africa than in Rome. ${ }^{1}$ The full context of the situation of the church in Africa is thus necessary to evaluate what those libri and epistolae of Speratus mean, with reference to a possible early Latin translation of some parts of the Bible.

This chapter intends to examine once more those texts which have been thought to indicate that Tertullian did in fact know some Latin translation(s) of some parts of the Bible. To some degree, new light can be thrown upon some of these texts. But their examination also will tell us something of Tertullian's own consciousness that the language of these translation(s), if such they were, was different, other; and, to a lesser degree, of his consciousness that biblical and Christian language itself was other. Tertullian feels the need to explain certain words and expressions. He is not wholly free in his selection of words; some were so much in usu that he feels constrained to use them, even though he knows the Greek which lies behind them, and often translates it for himself. This chapter, then, would do two things; examine the classic texts which have been thought to show Tertullian's awareness of Latin renderings which were not of his own making, and to show his reflex awareness that the language and style of the Bible, and the language of the Christian community was different, other than the Latin of nonChristian contemporaries.

Before beginning with an examination of these classic texts where Tertullian seems to testify to the existence of some Latin biblical translations, some attention should be given to the context of Tertullian's writings, and the situation of bis church.

Tertullian is an occasional writer. Karl Holl exaggerates slightly when he claims that only one of Tertullian's works was not provoked by some actual controversy or occasion: the de paenitentia. ${ }^{2}$ His works are strongly influenced by the pastoral or controversial concerns of the moment. Tertullian is always aware of his audience and his opponents. He tries to reach them by using their language, by appealing to their tastes. So he tried to reach the gilded classes among the Christians by writing a version of the de spectaculis in Greek, '...propter suauiludios nostros

1 Gustave Bardy, La latinisation de l'église d'Occident, Irenikon 14 (1937), p. 3-20; 113-130; La question des langues dans l'église ancienne, Paris, 1948, I, p. 58-60; 61-63; THEODOR KLAUSER, Der Uebergang der römischen Kirche von der griechischen zur lateinischen Liturgiesprache, Miscellanea Mercati, (Studi e testi, 121-127), Roma, Città del Vaticano, 1946, I, p. 467-482; Chrustine Mohrmann, Les origines de la latinité chrétienne à Rome, VC 3 (1949), p. 67-106; 163-183 (= ELC III, p. 67-126).

2 KarL Hold, Tertullian als Schriftsteller, Gesammelte Aufsätze zur Kirchengeschichte, Tübingen, 1923, I, p. 1-12; p. 3. 
Graeco quoque stilo...'. Tertullian is bilingual ${ }^{2}$, and while we do not have his Greek works, it is striking how he carries on the argument of his Latin works almost as if the original text of the Scripture was in that language. He does, of course, appeal to the Greek. But arguments from Latin words are very frequent. ${ }^{3}$ It is true that Tertullian is perfectly at home in Latin and in Greek; but it does not appear that he can depend on the same knowledge in all his readers.

There are liturgical indications, too, which point to Latin predominance." The Christians take inspiration for their songs from Scripture and elsewhere ${ }^{5}$; they read it forth in their gatherings ${ }^{5}$; there are those psalms, to which responses are made: '...quorum clausulis respondeant qui simul sunt...' ${ }^{7}$ Now it is highly probable that this was done in Latin. Latin names predominate in the records of the African church (a very weak index, it is true) ${ }^{8}$; the earliest texts appear in Latin, as well as in Greek. All this proves little; but it is well to set it forth as a prolegomenon.

\section{A BrIef Review of SOME Opinions}

The texts which we are to see have repeatedly been examined and interpreted by scholars. They have read their evidence in different ways, however. And so there have been varying opinions on the question: did Tertullian know any Latin version of the scriptures? A brief glance at some of these opinions will be useful.

Pierre Sabatier, one of the first workers in the area of ancient Latin biblical translations, thought that these translations did exist, and went back to apostolic times. ${ }^{\theta}$ In his classic book, Antignostikus, August Neander assumed the existence of a Latin version which Tertullian knew and used ${ }^{10}$. The first real effort to document the New Testament of Tertullian was the book of Hermann Rönsch, Das neue Testament Tertullian's. Acknowledging that Tertullian gives varying renderings

1 de coron. 6.3. $\quad$ a adu. Prax. 3.2.

s See, for example: de praescr. 25. 8-9; de spect. 3.4-6; de orat. $21 \mathrm{ff}$. Tertullian avoids appealing to the Hebrew, however: adu. Prax. 5.1.

4 For evidence of the predominance of Latin in the liturgy in Africa, see: Paut Monceaux, Histoire littéraire de l'A frique chrétienne, Paris, 1901; reimpression, Bruxelles 1963, I, p. 106. For the use of Scripture in the African church: P. GlauE, Die Vorlesung heiliger Schriften bei Tertullian, ZNTW 22/23 (1923-24), p. 141-152; E. DekKers Tertullianus en de geschiedenis der liturgie, Brussel, Amsterdam, 1947, p. 36-39.

5 apol. 39.18. ${ }^{8}$ apol. 39.3; de anim. 9.4. ' de orat. 27.

- Gustave Bardy, La latinisation de l'église d'Occident, Irenikon 14 (1937), p. 12 and ff.

- Pierre Sabatter, Bibliotum sactorum latinae versiones, Rheims, 1739-1743; Paris, 1751. Sabatier's opinion quoted by G. Aalders, De citaten, p. 2.

10 A. Neander, Antignostikus: Geist des Tertullians ${ }^{2}$, Berlin, 1849; passim, and note 2 , p. 228. 
of the same passage, Roinsch still thought it beyond question that Tertullian did know a Latin translation, and that his citations represent a Carthaginian translation of the New Testament which would be one of the earliest Latin translations. ${ }^{1}$

From assumptions, however, developed discussions. Theodor Zahn firmly denied that Tertullian knew such a Latin translation. Beginning with the controversy against Marcion, Zahn held that Tertullian was there translating from the Greek New Testament of his opponent. He then widened his argument, going on to refute the idea that Tertullian and the church of his time knew any Latin translation of Scripture. The freedom with which Tertullian cites, and the variety of the citations indicated for Zahn that Tertullian was translating from the Greek; and what consistency does exist in the citations was to be explained by the influence of an oral tradition of translation. ${ }^{2}$

One of the best considerations of the problem is that of Paul Monceaux. Writing at the beginning of this century, he insisted on the idea that some books of the Bible were translated before others. Outlining the opinions up to his time, he catalogues them into those which held that Tertullian knew the entire Bible in Latin translation, and those which held that Tertullian knew no Latin translation at all. Between the two extremes, Monceaux took a nuanced stand: for some books of the Bible, Tertullian did know a Latin translation, a version which is closely related to the citations made by Cyprian. ${ }^{3}$ This distinction remains important. It is impossible to speak of the Bible en bloc; the fortunes of the individual books have to be examined. Monceaux's discussion of the entire problem retains its value. He marshalls his texts from Tertullian and weighs them against the general context of the African church better than most writers.

Examining the Psalter in North Africa, Paul Capelle (later Dom Bernard Capelle, Abbot of Mont-César) regarded some of these classic texts which we have to examine as certain proofs that Tertullian did know a written, Latin translation of the Psalms, and also of other parts of the Bible. 4 In a brief article, Pierre de Labriolle studied the Tertullian

1 Hermann Ronsch, Das neue Testament Tettullan's, Leipzig, 1871, p. 43. See also, H. Ronsch, Itala und Vulgata 2 , Marburg, 1875, p. 2.

2 TheODor ZahN, Geschichte des neutestamentluchen Kanons, Erlangen, 1888; Ketne laternische Bibel um 200, p. 50 and $\mathrm{ff}$. See the comment of Hans von Soden on the position of ZAHN in: Der laternusche Paulustext bet Marcion und Tettullian, Festgabe Julicher, Tubingen, 1927, p. 229-281; note 1, p. 240-241.

3 Paul Monceaux, Hislozte littéraire de l'Afrique chrétrenne, Paris, 1901, Bruxelles, 1963; I, P. 106-118.

- Paul Capelie, Le texte du Psautter latn en Afrzque (Collectanea biblica latina, 4) Rome, 1913; p. 5; 19. 
texts which seem to point to his knowledge of a body of Latin scriptural translation. He came to the conclusion: 1) Tertullian usually translated from the Greek; 2) Tertullian did know some Latin translations, which he consulted, not as being authoritative or indispensable, but '... pour la satisfaction de sa curiosité toujours en éveil'. ${ }^{1}$

Chronologically, the work of Adolf von Harnack ought here be considered. It is convenient, however, to treat his reasoning, and the counter arguments of Gilles Quispel, later, in the special problematic which surrounds the adu. Marcionem..$^{2}$ Friedrich Stummer, in his inspection of these Tertullian texts, found that a Latin translation did exist, which had rather a greater effect on Tertullian than de Labriolle, for example, would be ready to admit. ${ }^{3}$

G. J. D. Aalders approached the problem for the Gospel texts in Tertullian by comparing his citations with the evidence which some mss. of Matthew and $70 h n$ in Latin translation offer. From this comparison, and after a brief treatment of the texts where Tertullian seems to speak of Latin translations, Aalders came to the conclusion that Tertullian was his own translator of the Bible, from the Greek; though he may have known one or several Latin versions, which might have exercised an influence upon him. ${ }^{4}$ In the first edition of the Lexicon fuir Theologie und Kirche, Heinrich Vogels authored the relatively short section of the article, Bibelübersetzungen which deals with Latin translations. ${ }^{5}$ Vogels had occupied himself in this area for years, and his opinion counts for much. He suggested that the first translation of the Gospels into Latin was made at Rome, and that this was of the Diatesseron of Tatian. In an earlier book, Vogels had cautiously suggested that Tertullian knew a Latin version of the Apocalypse, but that the freedom with which Tertullian makes his citations recommends great prudence in evaluating it. Meinrad Stenzel, another investigator into the fortunes of parts of the Bible in translation, summed up the general tendencies in the field in an article in 1953 . Here Stenze ${ }^{8}$ notes that

1 Pigrre de Labrolle, Tettullien a-t-il connu une version latine de la Bible?, Bulletin d'ancienne littérature et d'archéologie chrétiennes 4 (1914), p. 210-213. DE LABRIoLLE repeats his view in his Histoire de la littérature latine chrétienne (first published, 1924; third edition revised and augmented by Gustave BarDY, Paris, 1947) ; I, p. $71 \mathrm{ff}$.

2 See infra, p. $37 \mathrm{fr}$.

- Frmenich Stummer, Einführung in die lateinische Bibel, Paderborn, 1928, p. 11-14.

- Tertullianus' citaten uit de Evangeliên, p. 196.

- Lexicon für Theologie und Kirche', Freiburg im Br., 1930-1938, I, cols. 303-307. See also H. Vogess, Untersuchungen zur Geschichte der lateinischen Apocalypse-Übersetzung, Düsseldorf, 1920.

- M. Stenzel, Zur Frühgeschichte der lateinischen Bibel, Theologische Revue 49 (1953), cols. 98-103. 
most handbooks now agree that Tertullian knew and used some Latin translations; he however is of the opinion that the references which Tertullian seems to make to translations refer rather to the partial work of catechists, or to usage among Latin speaking Christians, rather than to any biblical translations, formally existent as such. Thus he, too, calls attention to the partial nature of such translations. It must not be supposed that we have to do with an entire Latin Bible at this early point; Monceaux had already pointed this out, but it is not always remembered.

In a review of the recent work done on the history of early Latin Bible translations, Dom Bernard Botte ${ }^{1}$ suggests an early date for the first of them: about 150 A.D. Dom Botte also makes the point that the study of old Latin biblical texts must follow the single books and groups of books of the Bible, and not globally assume entire translations of the Bible. When, therefore, we read that '... Tertullian testifies to the existence of a version of the whole Bible... This had no official character, and he criticises it on several occasions.' ${ }^{2}$, there is room for doubt on the score of that whole Bible.

Almost of all of the authors here cited depart from, or at least consider a certain number of places in Tertullian's works where he seems to speak of a Latin translation of some biblical texts; a translation for which he is not responsible, from which he sometimes distances himself, and which may have affected his own scriptural renderings. To work with the citations themselves is difficult. Tertullian is notoriously free in his citations. At times he is clearly translating for himself; and comparison with other texts, notably those of Gyprian, close in time and tradition to Tertullian, is sometimes not possible, and not always conclusive. The whole question is complicated further by the intrusion of a special question: in what language did Tertullian read the edited version of Marcion's New Testament, as he had it before him? This is a question quite separate from the larger problem of scriptural translations in the church of Tertullian. In the Marcion question, the names of von Harnack and Quispel are the most important. It seems best to treat with the texts from the adu. Marcionem separately - those, at least, which have direct bearing on the probable language of the Marcionite New Testament. As will appear, there are other texts from Tertullian which may cast new light upon the Marcion passages. The plan therefore, is to begin with a group of texts which are unaffected by the

1 Bernard Botte, (Vetsions) latines antérieures à S. Jéróme, Dictionnaire de la Bible, Supplément V (1957), cols. 334-347.

J. Quasten, Patrology, Utrecht-Brussel, 1958-1960; II, p. 244. 
polemic with Marcion; to pass on then to a second group of texts, where Tertullian glosses scriptural language with explanations. Then, and in the light of this glossing technique of Tertullian, we will come to the third and final group of texts: those from the adu. Marcionem. In the process, not only the question of the existence of a Latin translation of the scriptures will be discussed, but also Tertullian's awareness that scriptural language is other, and sometimes in need of explanation.

Texts unaffected gy the adu. Marcionem Polemic

NoN-GLOSSING TEXTS

1. de bapt. 18.1

(1 Tim. 5.22)

Ceterum baptismum non temere credendum esse sciunt quorum officium est. Omni petenti te dato suum habet titulum proprie ad elemosinam pertinentem. Immo illud potius respiciendum: nolite dare sanctum canibus et porcis proicere margaritam uestram et: manus ne facile inposueritis nec amartiis alienis communicaueritis.

We have here to do with a text which is not usually adduced as an index that Tertullian knew a Latin translation of the scriptures. It has recently been cited, however, by G. D. Kilpatrick ${ }^{1}$ to suggest that Tertullian may here be quoting from a Latin translation. While the editio princeps of Mesnart (1545), depending on a ms. now lost, read: aliena delicta, the modern editors reason that this reading was accomodated to the Greek, and they therefore read, with Trecensis, amartiis alienis. 'The presence of amartiis in the text of Trecensis suggests that Tertullian is here quoting a translation. If he had been making his own rendering we would have expected him to use delictum or another Latin word as he does elsewhere'. ${ }^{2}$ - so argues Kilpatrick, then, from the Trecensis reading.

The word amartiis here is, in fact, singular. It occurs nowhere else in Tertullian; according to the Thesaurus, $(h)$ amartia occurs only once elsewhere, in an inscription in a Roman catacomb: '...ut possit amartias meas indulgere'. Looking at the material in Beuron, under 1 Tim. 5.22, shows that amartia never again occurs as a translation of this passage. Tertullian cites 1 Tim. 5.22 once again, and in different language: 'Item ad Timotheum: manus nemini cito imponas neque communices

1 G. D. KILPaTruck, I Tim. V. 22 and Tertullian De Baptismo XVIII. 1, JTS n.s. 16 (1965), p. 127-128.

Ibid., p. 128.

a ThLL, VI, 3 fasc. 13, s.v. hamartia. The text of the inscription is to be found in E. DieHL, Inscriptiones Latinae Christianae Veteres, Berlin, 1961, I, no. 1558. Diehl's indices offer no further occurrences of the word. 
delictis alienis...'1 Delictum, $-a$, is frequently used by Tertullian, usually in biblical contexts. Delinquentia is also used ${ }^{2}$; it is interesting to note, however, that this word, almost always in the singular, occurs only in the fourth book adu. Marc. $(1 \times)$, and frequently, in the de resurr. and the de pudic. Peccatum, $-a$ is also used, somewhat less than the other two words.

What, then, is one to make of amartia here in this text from the de baptismo? While the value of Trecensis has recently been called into question, with respect to its scriptural citations ${ }^{3}$, the author of this article, Bruno Luiselli, does not consider the text here at issue. He sees some Trecensis readings (1 Cor. 1.27, de bapt. 2.3; Gen. 1.1, de bapt. 3,2; Marc. 1.4, de bapt. 10.6; Matth. 28.19, de bapt. 13.3) as corrections or normalisations of the original text. This does not seem to affect our text here, for the editors read it over the editio princeps, precisely because they feel that the latter has accomodated the text to the Greek.

There was a Greek version of the de baptismo, at least a partial one. ${ }^{4}$ This may affect the question here. Tertullian's full attention is not on the text; he does not have to concern himself here with opposing translations. Both of these considerations are important. It is possible that an early, catechetical work, ${ }^{5}$ as the de bapt. is, would reflect a partial, early, literal translation of the relevant passage of $1 \mathrm{Tim}$. It would then be a very old translation indeed, and one which never seems to have entered the mainstream of Latin biblical translation tradition. The case is really too isolated for any conclusion to be drawn.

\section{2. ad uxor. 1. 8.4 (1 Cor. 15.33)}

Conuictus atque colloquia deo digna sectare, memor illius uersiculi sanctificati per apostolum: Bonos corrumpunt mores congressus mali.

Here again we have a text which is not usually cited in the dossier of evidence for a Latin biblical translation known to Tertullian. Prof. Gilles Quispel notes the text as an example of Tertullian the active translator. Tertullian knows that Paul is citing a metrical passage from a poet, Menander. He then renders the verse into an elegant, metrical

1 de pudic. 18.9

2 It is too much to claim, however, as Hans von SoDEn does, that Tertullian prefers delinquentia as translation for the singular ápaería. See his Der lateinische Paulustext bei Marcion und Tertullian, Festgabe Fullicher, p. 229-281, p. 244; 266; 267.

a Bruno Lutselli, Il Codex Trecensis 523 e alcune Citazioni scritturali nel de baptismo Tertullianeo, Rivista di Cultura Classica e Medioevale, (1960), p. 209-216.

1 de bapt. 15.2.

5 On some works of Tertullian (and Cyprian) as presumable sermons, see: J. A. KNAake, Die Predigten des Tertullian und Cyprian, Theologische Studien und Kritiken 76 (1903), p. 606-639. 
echo of the only iambic senarius in the Bible; and he therefore is certainly not citing from the African translation which does not at all bring the meter out: 'conrumpunt ingenia bona confabulationes pessimae.'1 This text, then, would be a clear case where Tertullian has the Greek in the forefront of his attention, and where he is the active, independent translator.

As Quispel notes, Tertullian cites the text again in the second book ad uxor.: 'Bonos corrumpunt mores confabulationes malae.' (2.3.3). There are several things to be said here. Confabulatio, says the Thesaurus', does not occur before the 'Itala'; and the word occurs nowhere else in Tertullian. Congressus, on the other hand, is a favorite word of Tertullian. In the Vetus Latina material, we find that conloquia, colloquia dominate in the mss. of Latin translations of the passage. Cyprian has confabulationes pessimas, the testimonia conloquia mala. ${ }^{4}$ Nowhere in the Vetus Latina do we find congressus as a translation of this passage.

Augustine always has colloquia mala, colloquia praua; possibly sermones, in an allusion to 1 Cor. 15.33, but colloquia mala occurs shortly before this. ${ }^{5}$ Jerome is more interesting. We find confabulationes pessimae, malae $^{7}$, colloquia mala, (praua). ${ }^{8}$ Jerome knows that Paul cites pagan poets, and that their meter is not always respected in the Latin translations which he knows: 'Qui si metrorum ordinem atque mensuram in translatione non seruant, sciendum est in Graeco eos pedibus currere.' ; '...cuius iambici metrum, dum uerbum seruat ex uerbo, nequaquam expressit Latina translatio.' 10 As we will have occasion again to note, Tertullian is already a predecessor of Jerome and Augustine in their reflections on the existing Latin translations, and their shortcomings. This remark is premature here, as we have scarcely begun to see the evidence; but it will bear remembering.

1 Cor. 15.33 offers us a text where Tertullian clearly appears as the

1 Gilles Quispel, De Bronnen van Tertullianus' Adversus Marcionem, Leiden, 1943, p. 140-141. The text of the 'African' translation is cited from Hans von Soden, Das lateinische Neue Testament in Afrika zur Zeit Cyprians, Leipzig, 1909.

ThLL IV, col. 169, s.v. confabulatio.

s Cyprian, ep. 59.20 (G. Hartel, CSEL 3.2, p. 689, 1. 21-23); de cath. eccl. unit. 17 (Hartel, CSEL 3,1, p. 225, 1. 21); but we also find allusions before these references, using conloquia.

4test. 3.95 (Hartel, CSEL, 3, 1, p. 177, 1. 5).

- Enarr. in Psalmos, Ps. 128.8 (E. Dekkers and I. Fraipont, CC XL, p. 1886, 1. 20-21;

Ps. 128.4 has colloquia mala (Dekkers and Fraipont, CC XL, p. 1883, 1. 13-14).

- Comment. in Nahum, PL 25, col. 1257, and passim.

- Comment. in Esaiam, XIV, 1, 4/7 (M. Adriaen, CC LXXIIIA, p. 554, 1. 50).

- Comment. in ep. ad Tit., PL 26, col. 572, colloquia mala; col. 573, colloquia praua.

- Comment. in Esaiam, XIV, 1, 4/7 (Adriaen, CC LXXIIIA, p. 554, 1. 52-54).

10 ep. 130. 18.1 (I. Hilberg, CSEL 56, p. 198, 1. 27-p. 199, 1.1). 
active translator. But in its second occurrence, it shows that Tertullian is also in the tradition of old Latin biblical translations. Congressus, a favorite word of Tertullian, never appears again in the Latin translations of this text; confabulatio, a word that comes into usage only with the first Latin translations, and which remains witnessed in their tradition, does occur in Tertullian, although but once. Finally, it is well to note that nothing can be said even of the rest of 1 Corinthians here. For 1 Cor. 15.33 is a typical, quotable line, which appears in the testimonia, and no extrapolation is justified; we cannot say that the whole Epistle existed in translation at the time of Tertullian, on the simple evidence of this single citation. We have to do with partial translations, and fragmentary evidence. This text is moderately instructive, then, for the way in which Tertullian works.

\section{3. adu. Marc. 2. 9.1-2 (Gen. 2.7)}

Inprimis tenendum quod Graeca scriptura significauit, adflatum nominans, non spiritum. 2. Quidam enim de Graeco interpretantes non recogitata differentia nec curata proprietate uerborum pro adflatu spiritum ponunt et dant haereticis occasionem spiritum dei delicto infuscandi, id est ipsum deum. Et usurpata iam quaestio est. Intellege itaque adflatium minorem spiritu esse, ut aurulam eius...

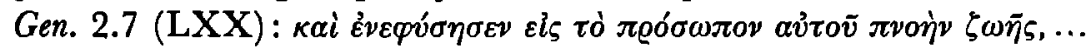
In this text, we have a classic example. Tertullian seems, on first reading, to be commenting upon a Latin translation of Gen. 2.7. He is not satisfied with the translation, because it is open to misunderstanding; Tertullian is nothing if not careful with words and their meanings. While this text is taken from the second book of the adu. Marc., it is not affected by the problem of the fourth and fifth books, scl., in what language did Tertullian read his Marcionite New Testament. It is, therefore, quite in place here in this first group of texts. It is a classic text, which almost all authors cite.

Quispel devaluates this text, however, pointing to a parallel in the de anima (11. 1-2):

Ita et animam, quam flatum ex proprietate defendimus, spiritum nunc ex necessitate pronuntiamus, ceterum aduersus Hermogenem, quia eam ex materia, non ex materia, non ex dei flatu contendit, flatum proprie tuemur.

2. Ille enim aduersus ipsius scripturae fidem flatum in spiritum uertit, ut, dum incredibile est spiritum dei in delictum et mox in iudicium deuenire, ex materia potius anima creditur quam ex dei spiritu. Idcirco nos et illic flatum eam defendimus, non spiritum, secundum scripturam et secundum spiritus distinctionem, et hic spiritum ingratis pronuntiamus secundum spirandi et flandi communionem. 
Using this text as a parallel, Quispel ${ }^{1}$ suggests that the adu. Marc. text means a good deal less than it has been made to say. The translation would be the work of the heretic Hermogenes, and he would have no need of a complete translation of the Bible. Genesis, and the opening chapters of Genesis were his only interest. In his commentary on the de anima, ${ }^{2}$ however, Waszink explains the passage 11.1-2 as meaning a change in the Greek text of Genesis by Hermogenes, where he read $\pi \nu \varepsilon \tilde{v} \mu a$ in place of $\pi \nu \circ \eta$. This need not be the case. Tertullian may here be speaking, just as in the adu. Marc. text, of a translation; but here it is a tendentious translation with heretical intent; in the $a d u$. Marc. text, simply an inexact translation which leaves itself open to false interpretation. In all events, the adu. Marc. text, so often cited as a proof that Tertullian knows a Latin translation which is independent of him, brings us no further than the opening chapters of Genesis.

Some light is thrown on this passage by the hesitancies which are evident in the Vetus Latina tradition. The published material for Gen. 2.7 reveals spiritum, spiraculum, flatum, animam, inspirationem, inspiramentum, as renderings of $\pi v 0 \dot{\eta}^{3}{ }^{3}$ We find Cyprian, in an allusion, still using flatum. ${ }^{4}$ The theological difficulties which Tertullian saw are also reflected upon by Augustine, in a highly interesting text: ${ }^{5}$

Notandum, quod scriptum est : in quo est spiritus uitae, non solum de hominibus sed etiam de pecoribus dictum propter illud, quod quidam de spiritu sancto volunt intellegere, ubi scriptum est: et insufflauit deus in faciem eius spiritum uitae, quod melius quidam codices habent: flatum uitae.

In the time of Augustine, then, flatus was still to be read as a translation of $\pi \nu \eta^{\prime}$, and, like Tertullian, he prefers it over the ambiguous spiritus.

In all events, Tertullian seems to reflect on the theological implications of a partial Latin translation. This text, a key text in certain controversies, was imperfectly rendered, if we follow the adu. Marc. view of it, or tendentiously rendered, if we follow the de anim. view. Tertullian, while he is sure that Gen. 1.2, $\pi \nu \varepsilon \tilde{v} \mu \alpha$, is the Spiritus $d e i^{\natural}$, is equally sure that $\approx v 0 \eta$ ought not be translated as spiritus. He consistently uses flare, adflare, and flatus when speaking of the text Gen. 2.7. He is 1 De bronnen.., p. 139.

2 J. H. WAszink, De Anima, Amsterdam, 1947, p. 11*-13*; see also, The Treatise against Hermogenes (ACW 24), Westminster, 1956, p. 7-8.

s See Genesis (Vetus Latina, 2), herausgegeben von Bonifatrus FischrR, Freiburg, 1951-54, ad loc. Gen. 2.7.

4 ep. 74.7 (G. Hartel, CSEL 3,2, p. 804, 1. 18).

- Quaest. in Hept., quaest. Gen. VIII (I. Fraipont, CG XXXIII, p. 4, $1116-121$ ); see also enarr. in Psalmos, Ps. 137. 4 (Dekkers and Fraipont, CC XL, p. 1980, 1. 16 ff.). - de bapt. $3.2 \mathrm{ff}$. 
clearly conscious of the Greek which lies behind the text, and disagrees with contemporary renderings. Whether these were oral or written, and how much of Genesis they embraced, is uncertain.

\section{4. de monog. 11. 10-11 (1 Cor. 7.39)}

Mulier uincta est quamdiu uiuit uir eius, si autem dormierit, libera est, cui uolet nubat, tantum in Domino.........

11. Sciamus plane non sic esse in Graeco authentico, quomodo in usum exiit per duarum syllabarum aut callidam aut simplicem euersionem: Si autem dormierit uir eius. Quasi de futuro sonet, ac per hoc uideatur ad eam pertinere quae iam in fide uirum amiserit. Hoc quidem si ita esset, in infinitum emissa licentia totiens uirum dedisset, quotiens amissus esset, sine ullo pudore nubendi etiam ethnicis congruente. Sed etsi ita esset, quasi de futuro, si cuius maritus mortuus fuerit, tantumdem et futurum ad eam pertineret cuius ante fidem morietur maritus.

A text which is often cited, and about which no real certainty seems possible. For de Labriolle ${ }^{\mathbf{1}}$, the text is inconclusive; Stummer admits that it is a '...viel umstrittene Stelle...', but feels that it does have some weight as a proof text that Tertullian is speaking of a Latin rendering. ${ }^{2}$

We are well into the rigorist period of Tertullian, and he would now forbid second marriages, reversing his stand in the first book ad uxor. The problem in the interpretation of the text lies in the dormierit, and the euersio duarum syllabarum. The text is cited in the testimonia (3.62), and it agrees in all important aspects exactly with the text as cited by Tertullian. The text, dormierit, has come in usum, says Tertullian. One would expect that he here refers to Latin usage of the Christians, and not another reading in the Greek, which some have tried to supply. ${ }^{3}$ Tertullian seems to object to the vagueness of si autem dormierit..., which is open to a future reading. ${ }^{4}$ But what he means by the euersio syllabarum - Tertullian hesitates, and does not know whether to attribute this to cleverness, or to the lack of it on the part of the translator - is not clear.

Both Jerome and Augustine give two forms: dormierit, and mortuus

1 Bulletin d'ancienne littérature et d'archéologie chrétiennes 4 (1914), p. 213.

2 Einführung in die lateinische Bibel, note 1, p. 13.

3 On the euetsio duarum syllabarum, see: William P. Le Saint, Tetullian: Trealises on. Marriage and Remarriage (ACW 13), Westminster, London, 1951, note 155, p. 164-165.

- Despite various efforts to find other possible readings in the Greek (see preceding note), no foundation for them is discerned in the apparatus at 1 Cor. 7. 39. A. Harnack would see the euersio in a change from dormit to dormierit, in his lecture: Tertullians Bibliothek christlicher Schriften, SbDAWB 1914, p. 307.

Even though one has the impression that Tertullian is referring to the ambiguity of dormierit itself, the euersio remains unexplained. 
fuerit. ${ }^{1}$ But since many of these are allusive, rather than directly cited, the difference in form may be for the sake of the argument. The codices of Paul agree on dormierit except for two, which give: '... quodsi dormitionem uir eius acceperit...'; and '... quodsi dormitionem...accipiet'. ${ }^{2}$ The impression is strong that Tertullian, in all events, is here disagreeing with a current, partial rendering, which is ambiguous, and therefore unacceptable. But it is not fully clear to us what he does mean. Therefore the text remains inconclusive. The reading with which he seems to disagree is very much in the mainstream of the tradition of the Vetus Latina.

This text brings us to the end of the first group of texts. There are others, still outside of the problematic of the fourth and fifth books against Marcion, which must be seen. They, too, represent classic texts; texts which have been cited frequently in the controversy about the existence of a Latin translation of the Bible and Tertullian. But they have a unifying characteristic. We have seen Tertullian reflecting on the theological and moral implications of what seemed to be Latin scriptural language - spiritus and dormierit being weighed and found wanting. We go no now to this second group of texts, where Tertullian reflects on linguistic usage among the Christians. To this second group, we will add examples of glosses by Tertullian; where he explains a word or a phrase which, he is afraid, may not be perfectly clear. We may then find that this glossing technique sheds a better light upon the third group of texts, the loci classici from the adu. Marc.

Glossing Texts outside adu. Marc.

1. scorp. $7.1 \quad$ (Prov. 9.2)

... qua ratione etiam ipse plus quam homicidam pronuntiauit ex sophiae suae persona, uoce Solomonis. Sophia, inquit, iugulauit filios suos. Sophia sapientia est. Sapienter utique iugulauit, dum in uitam, et rationaliter, dum in gloriam.

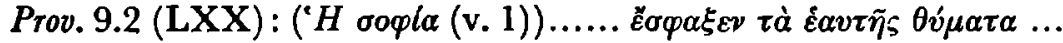
The aspect of this text which interests us here is the gloss: 'Sophia sapientia est.'. Before coming to this, however, the text itself, a curious citation of Prov. 9.2, needs a few words of comment. Since the LXX offers no variants for $\theta \dot{v} \mu a \tau a$, and since no other Latin author ever 1 Jerome, adu. Iovian., PL 23, col. 227, mortuzs fuerit; col. 234, dormierit. Augustine, de bono uiduit. (J. Zycha, CSEL 41, p. 309, 1.11; mortuus fuerit; speculum 31 (F. Weihrich, CSEL 12, p. 214: 1.11); dormierit. The Scripture citations of the speculum have, however, undergone influence of the Vulgate. Augustine prefers mortuus fuerit.

a Codex 75 (d., Claromontanus); Codex 76 (G., Boemerianus). 
cites the text as Tertullian does, how does Tertullian arrive at filios?

Alberto Vaccari suggested a confusion in Tertullian between the Proverbs text, and Eccli. (Sirach) 4.11-13. As he quotes this latter text: 'Sapientia filios suos exaltauit et suscipit inquirentes se; qui diligit illam diligit uitam...qui tenuerit eam haereditabit gloriam...'1, gloria and uita leap to the eye, and the expression of Tertullian, after citing the Prov. 9.2 text: 'Sapienter utique iugulauit, dum in uitam, et rationaliter, dum in gloriam' suggests in fact a confusion between the two texts. With equal acuteness, however, Prof. Bauer has recently challenged the Vaccari explanation. He rightly points out that uita and gloria are not echoes of a supposed allusion to Sirach, but are integral to the argument of Tertullian. He is explaining the actions of God the medicus, of God, who sets the struggle before the Christian (scorp. 5, 6). uita and gloria respond to the argument of Tertullian, and seen in this light, they are not echoes of the Sirach text; and with this, much of the attractiveness of the explanation which Vaccari offers disappears. ${ }^{2}$

Bauer's own explanation suggests that Prov. 9.3 read $\dot{\alpha} \pi \dot{\varepsilon} \sigma \tau \varepsilon \iota \lambda \varepsilon v \tau \dot{\alpha}$

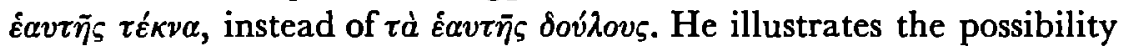
of this by parallels and examples from Origen. Bauer himself suggests the possibility that Tertullian himself has simply changed the text. But he hesitates: are we to suppose that Tertullian is 'eigenmächtig mit dem Schriftwort?'3 I would be ready to admit this possibility here, at least. ${ }^{4}$ Not simply as the only satisfying solution to a problem which has long been a vexing one, but because Tertullian seems to indicate that, in his citation, he is already giving an interpretation of the text. In scorp. 7.4 Tertullian interprets the Proverbs text Christologically; as the testimonia do, much less explicitly, and in different language: 'mactauit suam hostiam'. ${ }^{5}$ Now Tertullian makes a comment, which bears examination: in answer to the question, how can God require the death of man, when Christ has died once, and for all? (scorp. 1.8) How can it be said that God desire the death of man? (6.11) Tertullian

1 Alberto Vaccari, Scritti di Erudizione e di Filologia, Roma, 1958. Vol. II, p. 3-16; p. 6.

a Johannes B. Bauer, Drei cruces, Biblische Zeitschrift, neue Folge, 9 (1965), p. 84-91. On the text scorp. 7.1 (Prov. 9.2), p. 85-89.

s Ibid., p. 88.

4 In other places, Tertullian is ready to take liberties with biblical texts. Cf. SANTo Rossi, La citazione dei testi sacri nell" "Adversus Praxean", Giornale Italiano di Filologia (Napoli) 13 (1960), p. 249-260.

s test. 2.2 (Hartel, CSEL 3,1, p. 64, 1. 9); cf. also Cyprian, ep. 63.5 (Hartel, CSEL 3,2, p. 704, 1. 14-15) : mactauit suas hostias. See also the interpretation of Augustine, de ciu. Dei 17.20 (B. Dombart and A. Kalb, CC XLVIII, p. 588, 1. 59-72). 
gives a strong answer: 'ipse se plus quam homicidam pronuntiauit... 2. $O$ parricidii ingenium!' (7. 1.2) Knowing that he has treated the Proverbs text cavalierly, he goes on to tell his readers: '... uerba non sono solo sapiunt, sed et sensu, nec auribus tantummodo audienda sunt, sed et mentibus.' (7.5) Following on this, he goes on to speak of the uictima of the nationes. Taking all this together, it seems the best and the simplest explanation of the text citation to suppose that Tertullian is, in his citation of Prov. 9.2, already interpreting; that it is a hermeneutical citation, where uictimas is replaced with filios, with bearing upon Christ and the Christians.

These comments in passing, on a long standing difficulty in the scriptural citations of Tertullian. The aspect of the text which here interests us is the gloss: 'sophia sapientia est'. This text has been cited by many authors as an indication that Tertullian is citing a Latin translation, where oopia appears as sophia, and which Tertullian then explains, just as he explained Critas earlier in the scorp. (3.6) with Censores. ${ }^{1}$ This is possible. But from what we have already seen, this text is far too hermeneutical: that is, Tertullian, more didactic even than is ordinary with him, explains everything, and indeed even gives an exegesis of a text in the guise of a citation. For this reason, the text will not bear much weight in the controversy over a possible Latin translation known to Tertullian.

But this characteristic of Tertullian, his glossing, is highly interesting. Sophia is an ordinary word in Tertullian, with important theological meaning. ${ }^{2}$ It occurs frequently, adu. Hermog., adu. Val., and adu. Prax. being specially rich in the use of the word. Already in the de orat. $(1.4,5,6)$ the word is used to mean Christ, as the personified wisdom, while against the Valentinians, the word is usually a technical term of the Gnostics themselves. Tertullian goes on to use the word some nine times in the scorp.; addressing himself to the simplices, he is imaginative and didactic in a more than usual degree, and he feels that the words needs a glossing explanation. While sophia is an ordinary word in Tertullian, and in the testimonia also, it seems better not to take this text as an indication that Tertullian is glossing a scriptural translation, but rather that he is glossing a theological word, to make

1 See infra, p. 33.

2 On sophia, see: René Braun, Deus Christianorum: recherches sur le vocabulaire doctrinal de Tertullien, Paris, 1962, p. 275-280. On the text scorp. 7.1, Braun's note against Capelle, for whom this text was a strong indication that Tertullian knew a Latin biblical translation, note 5, p. 279-280. See also, on sophia as theological term: J. Morngt, Théologie trinitaire de Tertullien (Théologie nos. 68, 69, 70 and ?) Paris, 1966, III, p. 1033 and ff. 
perfectly sure that its meaning is clear. It is precisely this glossing technique of Tertullian which we will see in increasing measure.

\section{2. adu. Prax. 5. 2-3 (Foh. 1.1)}

Ante omnia enim Deus erat solus, ipse sibi et mundus et locus et omnia. Solus autem quia nihil aliud extrinsecus praeter illum. Ceterum ne tunc quidem solus; habebat enim secum quam habebat in semetipso, rationem suam scilicet. Rationalis enim Deus et $\dagger$ ratio in ipsum prius et ita ab ipso omnia. Quae ratio sensus ipsius est. 3. Haec Graeci hóyov dicunt, quo uocabulo etiam sermonem appellamus ideoque iam in usu est nostrorum per simplicitatem interpretationis sermonem dicere in primordio apud Deum fuisse, cum magis rationem competat antiquiorem haberi, quia non sermonalis a principio, sed rationalis Deus etiam ante principium, et quia ipse quoque sermo ratione consistens priorem eam ut substantiam suam ostendat.

This text is famous, not only for the evidence which it seems to give of a Latin translation of the beginning of $\mathcal{F}^{\circ} h n^{1}$, but also in the trinitarian theology of Tertullian. ${ }^{2}$ Tertullian comments upon a word, sermo, which is one of the hallmarks of the 'African' tradition in old Latin biblical translations; where Novatian in Rome, and afterwards our Vulgate would read uerbum as a translation of dóyos, Tertullian and Cyprian use sermo, used as a predicate of Christ (Joh. 1.1, 1.14).

Tertullian reflects on language which is not of his own making, and he distances himself slightly from that language; slightly, for he goes on to say: 'Tamen et sic nihil interest.' (5.4), for sermo implies ratio, and ratio sermo. ${ }^{3}$ From language which is not of his own making, but which

1 This text is discussed by all authors who deal with the problem of Latin biblical translation(s) and Tertullian. It is generally found to be one of the more convincing texts, though AALDERs thinks that it may refer to nothing more than an oral tradition. (De Citaten, p. 172). Rene Braun also depreciates the text, noting that Tertullian is not citing here with precision, and that in primordio is proper to Tertullian. (Deus Christianorum, p. 256-272; note 3, p. 264). in primordio is normal language for Tertullian; de bapt. 3.2, where BORLEFFs reads in principio and brackets in primordio, is a problem, following H. Koch (See apparatus, CC I, p. 278.) B. LuISELII would read in primordio here: the constant use of in principio in the adu. Hermog. $[3.5 ; 19.2,4$; $20.1,2(3 \times), 4(2 \times) ; 22.5 ; 25.1 ; 26.1(2 \times) ; 26.3 ; 31.1]$ is due to the exigencies of the argument there. See Il Codex Trecensis 523 e il De Baptismo Tertullianeo, p. 211-213. The uses in adu. Prax. are colored by the Johannine prologue: we find in principio: $5.1 ; 5.3 ; 13.3 ; 19.6(2 \times) ; 21.1(2 \times) ; 21.2$. In principio is open to false interpretation, and Tertullian explains the Greek which is behind it (adu. Hermog. 19.2), and glosses it: in principio, id est initio (adu. Hermog. 20.1). It is interesting to note that in initio nevers occurs, though Tertullian is fond of $a b$ initio. For Gen. 1.1 we find witnesses to in principio, in primordio, in initio: see Genesis (Vetus Latina 2) herausgegeb. von Bonifattus Fischer, Freiburg, 1951-54, ad loc., p. 3-5.

2 See: J. Morngt, La théologie trinitaire de Tertullian, p. $1019 \mathrm{ff}$.

a See the comment, in passing, of Chrustine Mohrmann on this: VC 3 (1949), 


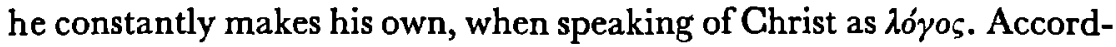
ing to Aalders, ${ }^{1}$ Tertullian always uses sermo as a translation of $\mathcal{J} o h .1 .1$, with but one exception, which is allusive language, rather than a direct citation: ${ }^{2}$

ostendens se esse Filium illum, et olim a Deo praedicatum et ad omnium salutem natum, Verbum Dei illum primordiale, primogenitum, uirtute et ratione comitatum et spiritu fultum.

As Aalders notes, this passage is preceded by one which illuminates it : 3 Iam diximus Deum uniuersitatem hanc mundi uerbo et ratione et uirtute molitum. Apud uestros quoque sapientes hóov, id est sermonem atque rationem, constat artificem uideri uniuersitatis....

11. Et nos autem et sermonem atque rationem, itemque uirtutem, per quae omnia molitum Deum ediximus, propriam substantiam spiritum adscribimus, cui et sermo insit pronuntianti, et ratio adsit disponenti, et uirtus praesit perficienti. Hunc ex Deo prolatum dicimus, et prolatione generatum, id idcirco filium Dei et Deum dictum ex unitate substantiae: nam et Deus spiritus.

These texts are interesting, because they show Tertullian balancing between two terminologies. He would use uerbum as equivalent with

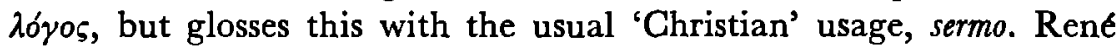
Braun draws up a table of the uses of sermo and uerbum as predicate of Christ ${ }^{4}$, taking Joh. 1.1 and 1.14 together. uerbum occurs only in apologeticum, de praescr., and de carn., with one reference in adu. Iud. We have seen the passages from apologeticum; the relevant occurrences in de praescr. come in the formulation of the regula fidei: 'Unum....Deum... esse...qui uniuersa de nihilo produxerit per uerbum suum primo omnium emissum...' 'Id uerbum filium eius appellatum...' (13.2 and 3). Here we are at some distance from a direct citation of $\mathcal{F} o h$. 1.1. Braun suggests that this use of uerbum is due to Roman influence, precisely in the regula fidei as Tertullian is citing it. There remain fifteen appearances in de carne of uerbum, which are striking and sudden. Usually in the formula: 'et uerbum caro factum est', repeated in several forms $(18.3,4(2 \times), 5 ; 19.2$; $20.3,6 ; 21.1,2)$. Braun would place the de cam. rather earlier in the chronology of Tertullian's work, alleging that it shows no traces of Montanist elements, and tends to explain the appearance of uerbum in Tertullian as belonging to the earlier works, and showing the development of Tertullian. Thus, when he comes to write the adu.

p. 166-167 (= ELC III, p. 109-111); J. MoINGT, La theologie trinitaire de Tertullien, p. 1044.

1 De Citaten, p. 171-172. The reading of $P$ in the adu. Prax. 21.1 is rejected by Kroymann and Evans; 21.2, using sermo again, and not uerbum makes the rejection of uetbum in 21.1 highly probable. See Aalders, De Citaten, p. 172.

apol. 21.17. s apol. 21.10. "Deus Christianonum, p. 267-268. 
Prax., he opts for sermo. ${ }^{1}$ The other hypothesis, mentioned by Braun as a possible explanation of the use of uerbum as predicate of Christ, seems more attractive. Tertullian is sensitive to language, and to the language of his opponents. $\mathrm{He}$ adapts himself to that language, as far as he can do so. It would seem that this is the best explanation of the apologeticum texts, where Tertullian uses uerbum, glossing it with sermo for the benefit of his Christian readers; and the sudden appearance of uerbum in the de carn. is very probably due to Tertullian's adoption of the language of his opponent; but this is not certain. Even while depreciating the value of the text $a d u$. Prax. 5. 2-3 as an indication that Tertullian knew a Latin translation of the scriptures, Braun admits that knowledge and influence in Tertullian, ${ }^{2}$ while claiming that Tertullian influenced the African tradition of translation definitively in favor of sermo.

The tradition of the Vetus Latina is not so rich in testimonies of sermo in the Johannine prologue as one might expect. Only one ms. has any indication of sermo, $\delta$, a Latin interlinear version of a Greek ms. (9th C. St. Gall), which gives both sermo and uerbum for $70 h$. 1.l. The situation is exactly the same for Joh. 1.14. Hartel, in his edition of Cyprian, has left but one text where sermo occurs; foh. 1.14 in ep. 73.5. ${ }^{3}$ While Hartel read uerbum elsewhere, as for $\mathcal{F}$ oh. 1.1 in test. $2.3 ; 2.6,{ }^{4}$ the reading of $L$, sermo, is doubtless to be restored here.

Finally, a text may be quoted from Augustine, which shows that he still knows sermo as a translation of the Johannine prologue גóros, although he himself regularly uses uerbum as a translation.

Augustine is commenting upon foh. 17.17:5

...sermo, inquit, tuus ueritas est. Quid aliud dixit, quam: Ego ueritas sum?

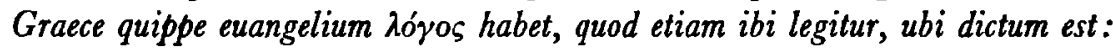
In principio erat Verbum, et Verbum erat apud Deum, et Deus erat Verbum.....Unde et hic poni potuit, et in quibusdam codicibus positum est: Verbum tuum ueritas est; sicut in quibusdam codicibus etiam ibi scriptum est: In principio erat sermo. In graeco autem sine ulla uarietate, et ibi et

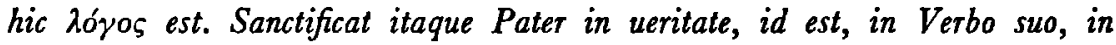
Vnigenito suo, suos heredes eiusque coheredes.

This reflection of uerbum and sermo contrasts with that of Tertullian. The linguistic demands of Tertullian are greater than those of Augustine. In all events, sermo was still known to Augustine as a translation of Joh. 1.1, 1.14, but as a translation which is no longer in use in his church.

1 Ibid., p. 269-271. \& Ibid., p. $269 . \quad 3$ (Hartel, CSEL 3, 2, p. 782, 1. 7).

4 (Hartel, CSEL 3, 1, p. 65, 1. 3-4; p. 70, 1. 7-8).

- In Iohannis Evangelium Tractatus 108. 3 (R. Willems, CC XXXVI, p. 617, 1. 1-13). 
Returning to our text, then, and concluding: sermo offers us an example of a word which Tertullian found as translation of the $\lambda \dot{o} \gamma o \xi$ of Joh. 1.1, 1.14. By his use of the word, he deepened its theological meaning, in the adu. Prax. The text which we have seen, taken together with the overwhelming preference which Tertullian has for sermo as translation of $\lambda o^{\prime}$ os, predicate of Christ, and in the context of the Johannine prologue, suggests that a translation did exist of this part of John's gospel. But caution is needed here, as always. For the prologue, and precisely $70 h .1 .1$ and 1.14 , were very frequently quoted, and they have a far more complex history than other, more neutral expressions of fohn. The evidence brings us no further than a partial translation of a section of the gospel which had peculiar theological interest. Tertullian's reflection on the word shows that it is not of his making; that it falls somewhat short of the universal accuracy that it might have, but is nonetheless acceptable. Much later Augustine will reflect on it, though not with the acuteness of Tertullian; by the time of Augustine, however, sermo was no longer of theological import, nor was it in usu. The discussion here has been limited to sermo and uerbum in the prologue of Fohn. For the uses of uerbum and sermo as translations of $e \tilde{\eta} \mu \alpha, \lambda \sigma^{\prime} \sigma o s$, the situation is much too complex and fluid to yield much clear evidence of a Latin translation used by Tertullian. ${ }^{1}$

3. de pudic. 4. 1-2

Possumus igitur demandata paenitentiae distinctionem ad ipsorum iam delictorum regredi censum, an ea sint, quae ueniam ab hominibus consequi possint. Inprimis quod moechiam et fornicationem nominamus, usus expostulat.

2. Habet et fides quorundam nominum familiaritatem. Ita in omni opusculo usum custodimus. Ceterum si adulterium et si stuprum dixero, unum erit contaminatae carnis elogium.

This text, cited by several authors, has never been central in the discussion of Tertullian and a possible Latin translation of the scriptures. For de Labriolle ${ }^{2}$, the text indicates a Latin interpretation of

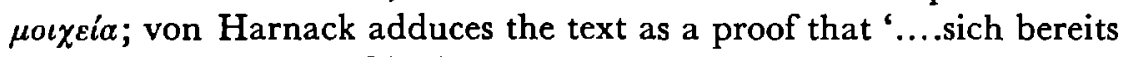
eine terminologische Glaubenssprache ausgebildet hatte'. ${ }^{3}$ But there is more to be made of this text, perhaps.

1 René Braun, Deus Christianorum, p. 269, disagrees with H. von Soden's statement that Tertullian used uerbum and sermo in equal measure. But von SODEN, Das lateinische Neue Testament in Afrika, p. 72, is referring to $\varrho \tilde{\eta} \mu \alpha$ and $\lambda \delta \gamma o \varsigma$ in a wider sense, and not as "Prädikat Christi"; see p. 71 also. On the latter words, Braun, op. cit., note 1, p. 270 says that, generally, Tertullian uses uerbum for $\varrho \bar{\eta} \mu \alpha$, sermo for $\lambda \delta$ 'ó in his Scripture citations.

2 Bull. d'ancienn. litt. et d'archéol. chrét. 4 (1914), p. 213.

3 Adolf von Harnack, Geschichte der altchristlichen Literatur bis Eusebius, Leipzig, 1958, Teil II, Bd. II, p. 299-300. 
The de pudic. deals with the edictum of a bishop (now generally thought to be Agrippinus in Carthage, and not Callistus in Rome ${ }^{1}$ ), which Tertullian cites, perhaps to the letter : ${ }^{2}$

Audio etiam edictum esse propositum, et quidem peremptorium. Pontifex scilicet maximus, quod (est) $\dagger$ episcopus episcoporum, edicit: "Ego et moechiae et fornicationis delicta paenitentia functis dimitto".

Tertullian goes on in the de pudic. to adjust his language to that of the edictum. Where Tertullian himself would use stuprum and adulterium, stuprare and adulterare, he adapts himself in the de pudic. to other language. As will be seen, the translation of the passage cited above, 4.2, is not as evident as it might seem to be. But the first thing that interests us is the evident change and adaptation of language in the scriptural citations in the de pudic.

If we do find Ex. 20.14 cited once, outside of the de pudic. as '...non moechaberis...'3, it is alluded to in terms of '...non adulterium...' in the

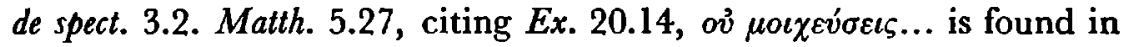
adu. Marc. 5. 17.15 as '...non adulterabis...', but in de pudic. 6.6 as '...non moechaberis...'

Matth. 5.28, $\dot{\varepsilon} \mu o^{\prime} \chi \varepsilon v \sigma \varepsilon v$, is alluded to indirectly in terms of adulterum (de paenit. 3.13), a facto stupri (de cult. fem. 2. 2.4 (2x)); is cited more directly as '...adulterauit in corde...' (de anim. $15.4 ; 40.4 ; 58.6$; de resurr. 15.4), as '...stuprauit eam in corde...' (castit. 9.2), alluded to as stupro (castit. 9.3).

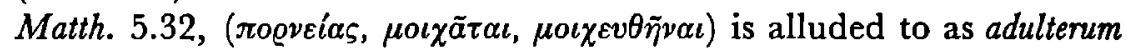
(de patient. 12.5), cited directly '...praeter causam adulterii, facit eam adulterari...' (adu. Marc. 4. 34.6); similarly, '...facit eam adulterari...adulteratur...' (de monog. 9.3); but in the de pudic. 16.17, we find: '...facit eam moechari.....moechatur'.

Taking the New Testament word rogveia, we find that Tertullian refers to this in terms of stuprum (ad uxor. 2.2.8), as adulterium (adu. Marc. 4. 34.6), where both passages refer to Matth. 5.32; but in the de pudic., we find moechia, as in 16.17 , or fornicatio. Thus, while 1 Cor. 6.18 is referred to in terms of adulterari in de monog. 9.6, we find fornicari

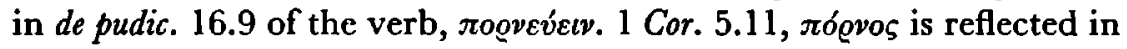
de idol. 14.5 as adulteri, in general terms of stuprum (ad uxor. 2. 3.1), but, in the de pudic. 18.7, fornicatores is the term used. Apoc. 2.20-22 is alluded to in quite general terms, stuprum, in de paenit. 8.1 ; in de pudic.

1 On this question see: Bernhard Poschmann, Paenitentia secunda, Bonn, 1940; reimpression, 1954, p. 348-367; on the specific question of the identity of the bishop, B. Altaner, in Theologische Revue (1939), p. 129-138; William P. Le Saint, Tertullian: Treatises on Penance (ACW 28) Westminster and London, 1959.

a de pudic. 1.6. adu. Iud. 2.3. 
19. 1-2, however, the passage is presented in terminology, fornicatio, moechia.

One last example. Once content to describe the sin of David generaly as delictum, (adu. Marc. 2. 17.2; 4. 10.3; 5. 11.2), Tertullian is more detailed in the de pudic.: '...caedem et cum ea moechia...' (21.5). It is quite clear, therefore, that he goes out of his way in the de pudic. to use the terminology moechia et fornicatio. Evidently, this is language adaptation on the part of Tertullian. He adapts the language of his scripture citations, and the general language of the discussion, to the terminology which seems to be that of his opponents, and of the edictum. This is all the clearer when we approach the problem from a study of the key words, moechia and fornicatio, and their related words, in the works of Tertullian.

moechus, $-a$ : occurs 23 times in the de pudic., once only elsewhere (apol. 15.1: '...moechum Anubin...').

moechari: always used of a scriptural citation, or in a scriptural context, this work is used 10 times in the de pudic., but only once elsewhere ( $a d u$. Iud. 2.3, citing Ex. 20.14).

moechia: used 40 times in the de pudic., twice elsewhere (de monog. 4.5; scorp. 3.5, where Tertullian refers, in biblical terms, to moechia as the soror idololatriae).

fornicarius, $-a$ : occurs 3 times in the de pudic., once in de anim. 35. 1.

formicator: 33 times in the de pudic.

formicari: $\quad 6$ times in de pudic., once elsewhere (scorp. 3.4).

fornicatio: 46 times in de pudic., four times elsewhere (adu. Marc. 5. $7.4(2 \times)$; 7.5; de monog. 11.6).

This gives clear evidence that Tertullian, in his scriptural citations, and in his terminology, goes out of his way to use moechia and fornicatio massively in the de pudic. Now this concern with language seems to be motivated by the language of his opponent, the edictum of the unnamed bishop: 'Ego et moechiae et fornicationis delicta paenitentia functis dimitto.' (de pudic. 1.6). Tertullian calls attention to his use of language with the words which we have seen: 'Habet et fides quorundam nominum familiaritatem. Ita in omni opusculo usum custodimus...' (4.2); he then goes on to note that this terminology is not essential to the argument, as he did in adu. Prax. 5.3,5. But he does, nonetheless, conform himself to usus.

After this short lexical study of the language used in scriptural citations, and the terminology used in the central argument of the de pudic., the translation of the passage 4.1-2 is worth re-examining. Three standard translations agree, essentially, in their wording of it, 
but one may well ask if the rendering is correct. This is not crucial to the point which already has been made: that Tertullian adapts himself in the de pudicitia to the language which usus demands. With this care for language, it is not evident that Tertullian is the sophist that the usual translation would depict him to be. We find the following three translations of the passage, de pudic. 4. 1-2, beginning with Inprimis:

In the first place, (as for the fact) that we call adultery likwise fornication, usage requires (us to do so). "Faith", withal, has a familiar acquaintance with sundry appellations. So, in every one of our little works , we carefully guard usage. Besides, if I should say "adulterium", and if "stuprum", the indictment of the flesh will be one and the same. ${ }^{1}$

Tout d'abord, si nous appelons aussi fornication l'adultère, c'est que l'usage le veut. La foi a, elle aussi, l'habitude de certains termes: ainsi dans tout cet opuscule nous restons fidèles à l'usage. Au surplus, que je dise adultère ou que je dise stupre, c'est la même étiquette attachée à la chair souillé. ${ }^{2}$

In the first place, usage requires that we speak of 'fornication' also as 'adultery'. There is a certain familar terminology which faith, withal, employs, and, accordingly, throughout our little treatise, we shall follow accepted usage. However, whether I say adulterium or stuprum the indictment of sinful flesh is one and the same. ${ }^{3}$

To the translations cited may be added the German version by Kellner, which, while not clear on the identification, explains in a footnote that Tertullian is here 'sophistically' setting fornicatio on the same footing as 'Ehebruch'.4 In a note, La Saint admits as a possible, but less probable translation of in omni opusculo, 'In each of our little works's. The translation for which he opts, however, is certainly correct. Tertullian is calling attention to the special effort which he is making to adapt himself to language, language which he himself does not ordinarily use. This effort is peculiar therefore to the de pudic., and revolves about the terms moechia and fornicatio. These are part of the specialised lan-

1 Thelwall's translation in: The Ante-Nicene Fathers, edited by Alexander Roberts and James Donaldson, (American edition) New York, 1902 1905, Vol. IV, ad loc., p. 77.

2 P. DE LABRIolle's translation in: Tertullien; de paenitentia, de pudicitia (texte latin, traduction française, introduction et index), Paris, 1906, ad loc., p. 71.

3 William P. Le Saint's translation in: Tettullian: Treatises on Penance (ACW 28), Westminster and London, 1959, ad loc., p. 61.

4 A. H. Kellner and Gerhard Esser, Tertullians Ausgewählte Schriften (Bibliothek der Kirchenväter), Kempten and München, 1915, Vol. II, ad loc., p. 387; noteone, ibid.

- William P. Le SaINT, op. cit., note 86, p. 207. 
guage of 'fides', which, while the German translation already mentioned gives 'Theologie' as a rendering, is certainly broader in scope.

Now the view of all three translations cited above is that Tertullian identifies moechia and fornicatio, and that this identification represents some Christian usage, or scriptural translation, ${ }^{4}$ of which we are unaware. But Tertullian does nothing of the sort. If anything, it is he who would like to identify the two, and make no distinction in judging them, as the following context shows (4.4). His own language in this area is usually stuprum and adulterium. There are two problems here, therefore; the problem of nomenclature, and the problem of making a moral distinction between the two sins. But to think that Tertullian is identifying moechia and fornicatio goes against the lexical evidence of the de pudic. Tertullian has gone to some lengths to adapt the language, moechia and fornicatio. He now cites scripture texts in this terminology, and now uses these words massively.

Now, as is well known, Tertullian is a very careful constructor. Thus, in the organisation of the de pudic., he handles moechia first, which is a subdivision of fornicatio (5.1); but in chapter 13, where he begins to handle the difficult case of Paul and the incestuous Corinthian (1 Cor. 5.1 and ff.; 2 Cor. 2.5 and ff.), he begins to deal with fornicatio. Tertullian is careful to keep both terms in the forefront of his attention, throughout the treatise; after quoting the edictum (1.6), he goes to link the two constantly $(1.14 ; 1.15 ; 1.20 ; 1.21$ etc.). He gives a preview of the order which he intends to follow in chapter 2, and it is the order which he does in fact pursue, and which is represented by the attention first to moechia, then to fornicatio. When therefore we come to the critical chapter 4, it is strange indeed to think that Tertullian is going to identify the two, and refute his opponents by melding the two sins together. He has something else in mind. First, he would rather speak of stuprum and adulterium, and, now in his Montanism, he would prefer not to distinguish between them. But usage requires him to speak of two sins, and to speak of them in terms of moechia and fornicatio; and this he does, as the lexical study has shown. One is tempted to see in the nominare the legal meaning of charge, indict ${ }^{2}$, the more so in view of the word elogium. But this is not necessary. The following translation of the passage, then, is suggested:

In the first place, that we should speak of moechia and fornicatio, is due to usage. 2. For Christianity, too, has it own special sort of words. And therefore we have kept to usage throughout this book. Besides, if I

1 Ibid., notes 95 and ff., p. 207.

2 See: Lewis and ShORT, $A$ Latin Dictionary Oxford, 1879, s. vv. elogium, nomino. 
were to speak of adulterium, or stuprum, it would still be the same indictment of sinful flesh.

This excursus on the passage de pudic. 4.1-2 may seem disproportionately long; but the singular care with which Tertullian uses terminology here is well worth bringing out, the more, since the usual translation obscures that precision of language, and that adjustment to other terminology which is the interesting aspect of the passage, and of the de pudic. as a whole. The question: to whose language does he adapt himself, is more difficult. Hermas, once so authoritative for the audience to which Tertullian spoke, and for which he himself showed respect (de orat. 16.1), is now called the '...scriptura "Pastoris", quae sola moechos amat...' (de pudic. 10.12), and is judged to be non-canonical. The view of penitence which Hermas expresses - very probably in mand. 4.1 - is unacceptable to Tertullian. Perhaps we have a hint here that Tertullian read Hermas in Latin, and that his abuse of it is consistent with the scriptural language used there, as well as with the language used in the edictum. ${ }^{1}$

This brings us back to the scriptural language problem. Tertullian, in his scriptural citations in the de pudic. which have bearing upon the moral problem there discussed, is using language which is not ordinary for him, and which colors those citations as they appear in his other works. Now, as we look at the material in the Vetus Latina tradition, the words moechia and moechari are very common for Matth. 5.27, 28, 32, as well as for Ex. 20.14; and, while we do find adulterare, this tradition never uses stuprare, stuprum, which, as was noted, is a word which Tertullian does use to reflect the scriptural loci in question. It is therefore probable that Tertullian is in contact with a tradition of scriptural translation here which he does not ordinarily follow. This tradition is evident only through the moral theology language of the edictum, but it is suggestive that Tertullian changes the usual language of his biblical citations to harmonise with that language, and with another tradition. ${ }^{2}$

1 On Tertullian's possible knowledge of Hermas in Latin, see: A. HARNACK, SbDAWB 1914, p. 313 and the references there.

2 It is interesting to compare Tertullian's treatment of moechia and fomicatio, here in the de pudicitia, with Augustine's discussion of a similar problem of terminology (Quaest. in Hept., quaest. Ex. LXXI.4 (I. Fraipont, CC XXXIII, p. 104, 1. $1195-$ p. 105, 1. 1235):

Item quaeri solet utrum moechiae nomine etiam fornicatio teneatur. Hoc enim graecum uerbum est, quod iam scriptura utitur pro latino; moechos tamen graece nonnisi adulteros dicit. Sed utique ista lex non solis uiris in populo uerum etiam feminis data est.....Sed utrum, si faciat, qui uxorem non habeat uel femina quae uirum non habet, praecepti huius transgressione teneantur, merito quaeritur. Si enim non tenenlur, non est prohibila in decalogo fornicatio, sed sola moechia, id est 
One last feature of the de pudic. may be mentioned. Tertullian the Montanist is highly conscious of being other. That feeling which he had earlier, as an orthodox Christian and apologist, is very strong in the ad nat. and apol., with the opposition, uos - nos. Here, in the de pudic., he now feels himself to be on the few lovers of the truth, over against the plures, among whom he once numbered himself $(1.10)$; the practice of his own sect was to make no distinction, apparently between moechia and fornicatio (4.4), and this, as we have seen, is yet another reason for correcting the translation of 4. 1-2. Other references to this consciousness of a new otherness occur in the de pudic. (9.1, on the interpretation of parables, perhaps to be seen in this light; 19.5, on the reception of heretics into the Montanist church). It is a very curious fact that Tertullian now, when he feels himself and his sect to be set off against the great Church, chooses to use the language of that church; when, in his orthodoxy, he apparently differed with that language in his own scriptural citations.

In this second group of texts just studied, - Prov. 9.2, scorp. 7.1; foh. 1.1, adu. Prax. 5.2-3; and the text de pudic. 4.1-2 - we have seen places where Tertullian comes in contact with scriptural, or Christian language which is not of his own making. Sophia, sermo, moechia and fornicatio all require comment on his part. He glosses the words with a comment, or he explains them; but he remains, as he says, faithful to usus, in his use of them. Tertullian's sensitivity to language, and to its theological implications, leads him to gloss many terms with explanations; and it seems that this characteristic of Tertullian is important, and worth comment. At least one facet of the bewildering variety of scriptural citations in Tertullian is explained by his comment and consistent practice in the de pudic. Some light may be thrown on the difficult texts from the adu. Marc. if we preface the discussion of them, the third group of texts, with an exposition of the glossing characteristic of Tertullian. This will also give a certain insight into Tertullian's awareness of language, and specifically, his awareness that biblical, and Christian language was other, and in need of a glossing explanation.

\section{Glosses of Tertullian}

Tertullian is sensitive to language. It is typical of his desire for clarity

adulterium, quamuis omnis moechia etiam formicatio esse intellegitur......moechia etiam formicatio in scripturis dicitur. Sed utrum etiam omnis fornicatio moechia dici possit, in eisdem scripturis non mihi interim occurrit locutionis exemplum..........Sed si furti nomine bene inlellegitur omnis inlicita usurpatio rei alienae...profecto et nomine moechiae omnis inlicitus concubitus atgue illorum membrorum non legitimus usus prohibitus debet intellegi. 
(so important for his exegesis) that he usually proceeds to a definition of terms as one of the first steps in a discussion. Ambiguity is offensive to him. He sets out the meanings of evil against the Marcionite view ${ }^{\mathbf{1}}$; complains that heretics seize on certain words and twist their meanings ${ }^{2}$ the clarity that he would have (as, for example, in de carn. 13.1-4), is often expressed in an either-or option that leaves no middle ground. ${ }^{3}$ He tends to apologise for his reflections on scriptural language, saying that he is forced to them: 'The heretics thus force us to be rhetors, as the philosophers force us to be philosophers..."4

His concern with words is not merely stylistic. He sees the theological import of words like sermo and adflatus. He is not independent in his choice of words. Usus directs him to use some; his adversaries use certain words, and he attempts to adapt himself to their usages, as far as he can do so. He is dependent on Greek for some words, and he seems to apologise for the many Greek technical terms which he is compelled to use in the $a d u$. Val., words for which no equivalent existed in Latin. ${ }^{5}$ Similarly, in the de anim. he has to appeal to Greek ${ }^{\mathbf{\theta}}$; in the apol. 21.10 he sets out the Greek dóros with the Latin ratio and sermo. Exomologesis, the act of second penitence, '...magis Graeco uocabulo et exprimitur et frequentatur... ${ }^{7}$ There is something defensive in his use of these words; though earlier, in the ad mart., for example, he sprinkles his text with Greek technical terms from sport with hardly an explanation.

More interesting is the attitude of Tertullian toward biblical expressions. He is conscious that the biblical 'style' is different. That Paul begins a letter with '...gratia uobis et pax...', and not with salutem, in the classical manner, calls for comment; Tertullian explains this by scriptural usage, and by contemporary Jewish custom. ${ }^{8}$ An excellent example is found in the adu. Marc. 4. 10.1: 'Videbit enim, inquit Esaias, populus sublimitatem domini et gloriam dei. Quam sublimitatem et quam gloriam? Conualescite, manus dimissae et genua dissoluta - hoc erat paralysis -; conualescite, ne timete, non otiose iterans "conualescite" nec uane subiungens "ne timete"...' The repetition of conualescite, and the expression genua dissoluta draw explaining comments from Tertullian. The scriptural manner of speaking is different. Tertullian explains two chief peculiarities of Scripture, a good understanding of which is basic to the adu. Marc. polemic. These peculiarities are prophecy, by which the future is announced as if present, and allegory, by which another

1 adu. Marc. 2. 14.3. \& adu. Hermog. 19.1.

s As, for example, adu. Prax. 9.4. \$ de resurr. 5.1. B adu. Val. 6. 1-2; 14.1.

- de anim. 14.2, etc. ' de paenit. 9.2.

adu. Marc. 5.5.1. 
meaning is intended than the literal (but impossible) one. ${ }^{1}$ Scripture has expressions and words which are not immediately clear to the unalerted reader. Thus Scripture speaks allegorically of the resurrection, in images of clothing, and Tertullian calls attention to this ${ }^{2}$; idolatry is expressed in the figure of stuprum in the scriptures ${ }^{3}$; by a kind of modesty, the scriptures say ludere, where lusum impudicum is meant ${ }^{4}$; they are compressed and pregnant in their expression. ${ }^{5}$

For all that, Tertullian would have it that Scripture is simple, direct. Simplicitas, an important word in his exegesis, is said in praise. Those serpents which are the signs of '....spiritalia malitiae...' are accounted for also, should real serpents be intended; Tertullian is reluctant to concede that the Scripture means anything more or less than it says. ${ }^{6}$ So far is Tertullian from criticising the 'rhetoric' of Scripture, that he praises it, and its manner of speaking. Eleganter is used frequently of scriptural expressions which require comment. Thus, of the arrangement of the petitions in the Prayer ${ }^{7}$, of an answer of Christ ${ }^{8}$; if we find '.fliiis hominum..', instead of 'hominibus', this is also eleganter said, and indeed, for perfect clarity. ${ }^{9}$ The expression of Paul, domus, in 2 Cor. 5.1 is eleganter put (even though it causes Tertullian some difficulty in his argument) ${ }^{10}$; this whole passage is instructive for the passion Tertullian has for perfect clarity.

Dependent on Scripture for much of his language, and conscious of the otherness of that language, Tertullian does not apologise for this, but he does make every effort to make the language and the imagery of Scripture perfectly clear. It is of interest to note some of the glossing comments which Tertullian makes upon typically scriptural language, quite apart from the question of whether he read his Bible in Latin or in Greek, or both.

Words like amen, alleluia are not really explained by Tertullian, but he does show awareness that they are different ${ }^{11}$; drachma (dragma), '..id est homo..'12, mna, '..id est unum uerbum eius...13, quadrantem, '..id est

1 adu. Marc. 3. 5.1; cf. 4. 25.1. Elsewhere, as in scorp. 11.4-7 the allegorical possibilities are much more limited by Tertullian.

de resurr. $27.1 \mathrm{ff}$.

3e idol. 1.2; de pudic. 5.4, in other language: moechiae nomine et formicationis.

- 'Intellege sanctae scripturae uerecundiam..', de ieiun. 6.2.

- '.. adoro scripturae plenitudinem..', adu. Hermog. 22.5.

- '..salua simplicilate scripturae..', adu. Marc. 4. 24.10.

7 de orat. 6.1. 8 adu. Marc. 4. 18.7.

- adu. Marc. 5. 8.5.

10 de resurr. 41.2. 11 amen: de spect. 25.5; alleluia: de orat. 27.

12 adu. Marc. 4. 32.2; cf. de pudic. 7. 20-21.

1s de praescr. 26.3. 
modicum usque delictum..' ${ }^{\prime}$, and the comments on $\operatorname{mam}(m){ }^{\prime} a^{2}$ are not so much explanations of words, as they are exegetical glosses of what is meant. They do, however, illustrate Tertullian's interest in clarity, and his consciousness that he is dealing with strange expressions. ${ }^{3}$ uae is always scriptural in Tertullian; it is uae illud ${ }^{4}$ and he and Marcion disagree on what the term means. ${ }^{5}$

caro et sanguis. Frequently used, this expression causes Tertullian some difficulty in explaining the resurrection of the body, and in passages which are parallel with one another in time, and in intention, he explains it ${ }^{6}$; Aegyptus, Babylon, Samaria are symbolically meant in the Bible, Samaria for idolatry?, Aegyptus for '..superstitionis et maledictionis elogio..' ', Babylon, as used by the Apocalypse (18. 10), for example, is the '..Romanae urbis figura..'.$^{9}$ Looking at other words which are rooted in the Bible, and which, Tertullian feels, stand in need of comment, we may note:

angelus. An important word in the de carn., where, as usual, Tertullian reflects the arguments and the language of his opponent, Tertullian glosses the word: 'ipsum flium angelum, id est nuntium Patris...'10. The gloss is at once an explanation of the word, and of its use in the doctrine of his adversary. Apol. 22.1 is also instructive on the meaning of the word, and Tertullian explains Satanas here, too; as again in de test. an. 3.2, '..quem nos dicimus malitiae angelum..'

apostolus. Tertullian explains the word: '..quos haec appellatio missos interpretatur...'11. As is well known, the word apostolus, absolutely used, means Paul' ${ }^{12}$; when another is styled apostolus, Tertullian adds the name: '..Petro apostolo...'13, 'Apostolus Iohannes..'14.

Christus, Christianus. Tertullian frequently returns to these words, to

1 de orat. 7.2 .

2 adu. Marc. 4. 33.1-2; de fug. 13.2.

- Adonai is an interesting case. Tertullian uses the word three times, in the citation of Ezech. 37.1, ff., de resurr. 29. 2-15, and nowhere else. Whatever the source of Tertullian's translation here, it is not dependent on the LXX as we have it. (See E. Evans, de resurrectione carnis liber, p. 261-262). Adonai is not elsewhere witnessed to in citations of Ezech. 37. 1-14 in the Vetus Latina. Our text of the LXX reads rvelos

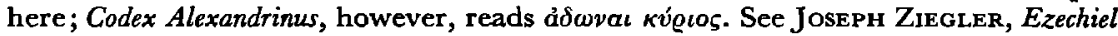
(Vetus Testamentum Graecum, auctoritate Societatis Litterarum Gottingensis, XVI, pars 1) Göttingen, 1952, ad loc. It is precisely in Ezechiel that this translator uses adonai very frequently. Rent BRAUn, Deus Christianorum note l, p. 102 comments that Tertullian does not list adonai among the names of the Father in adu. Prax. 17.2.

4 adu. Hermog. 22.5; de castit. 9.5; de monog. 16.5.

5 adu. Marc. 4. 15.3; 41.1 ff. adu. Marc. 5. 10.11-15; de resurt. 49.1.

7 adu. Marc. 3. 13.8-9. s adu. Marc. 3. 13.10.

- adu. Marc. 3. 10.10. 10 de carn. 14.4; cf. 14.3. 11 de praescr. 20.4.

12 de bapt. 14.1 ; ad uxor. 1. 3.2; 3.6; adu. Marc. 5, passim, etc.

13 de praescr. 33.12. 14 adu. Marc. 3. 24.4. 
explain them by etymology. '..unde Christi dicti a chrismate quod est unctio..' 1 , and here we have a gloss upon a gloss.

cor. In the de anim. Tertullian deals with the classic question of where the hegemonikon is to be localised. He gives his explanation from the Bible, and gives it as an opinion which is peculiar to Christians ${ }^{2}$; the Bible is his book of proofs, illustrations and commonplaces. Later, he explains what is meant by the biblical cor terrae, and there are other interesting texts where Tertullian reflects upon the biblical cor. ${ }^{3}$ debitum. Commenting on the Prayer, Tertullian gives an exegetical gloss of the scriptural debitum: '..debitum autem in scripturis delicti figura est...'4

elementa. In his exegesis of Gal. 4.9, Tertullian opts for what was to become a classic explanation of the elementa mentioned by Paul: 'Elementa autem apud Romanos quoque etiam primae litterae solent dici.." ${ }^{5}$; he returns to this explanation again at the end of the same passage, and again, later in the adu. Marc. ${ }^{\theta}$ It seems preferable to see this as a glossing comment, not on Greek usage, but on a biblical expression.

lux. The biblical imagery of light, of some importance in Tertullian, is explained: '..lucis, id est ueritatis, et tenebrarum, id est fallaciae..."7 While Tertullian usually simply makes use of this imagery, without attending to it, he does give comments upon it ${ }^{\mathrm{B}}$, or upon the East, as figura Christi. ${ }^{9}$ mulier. In this word, and attendant ones such as femina, uxor, uirgo, etc., we have a good example of the trouble that Tertullian takes to explain words, and to assure them of a clear and defined content. The whole intricate argument of the fifth chapter de uirg. uel. need not occupy us; but Tertullian tells us that the fact that '..mulieres nostras dicamus uxores, quamquam et impropie quaedam loquamur..' is due ultimately to the way in which Scripture expresses itself ${ }^{10}$; this is the more remarkable, in that Tertullian knows that this practice is general, and is not something specifically Christian: 'Hinc ergo tacita conscientia naturae ipsa diuinitas animae in usum sermonis eduxit nescientibus hominibus, sicut et alia multa, quae ex scriptura fieri et dici solere alibi poterimus ostendere...'11 He prefers to

1 de bapt. 7.1; cf. ad nat. 1. 3.9, // apol. 3.5, etc.; adu. Marc. 3. 15.1-2; adu. Prax. 28.1, $3,4,8$, etc.

${ }^{2}$ de anim. 15. 1-6. Cf. J. H. Waszinx, De Anima, p. 219-229.

$\mathrm{s}$ "in corde terrae...id est in recessu intimo et interno et in ipsa terra operto et intra ipsam clauso et inferioribus adhuc abyssis superstructo.', de anim. 55.1. Other passages where Tertullian reflects on cor: adu. Marc. 5. 11.5-8; de resurr. 15. 3-5, imitating de anim. 15.4; de resurt. 40.5 ; de monog. 10.8 .

1 de orat. 7.2. $\quad$ s adu. Marc. 5. 4.5.

- adu. Marc. 5. 4.5; 5. 19.7. T adu. Marc. 3. 8.3.

- de cult. fem. 2. 13.1 .

- adu. Val. 3.1. 10 de uirg. uel. 5.3. 11 Ibid. 
root the usage in Scripture, rather than in the example of Greek idiom. ${ }^{1}$ The explanation of mulier will cause Tertullian some difficulty later ${ }^{2}$, and it is terminology which often occupies him. ${ }^{3}$

Paracletus. A biblical word, paracletus is also a word which is specially important for Tertullian the Montanist. The deductor omnis ueritatis and his revelation were central in Montanism. Another word, which we will see shortly, ecstasis, is also prominent in the context of Montanism. We have here to do with a word which is not simply biblical, but which has a special content for a special group. In any case, Tertullian glosses Paracletus, which he treats as a proper name, in this way: '..paracletus, id est aduocatus..'4 It is also interesting to see how Tertullian translates those New Testament passages where paracletus occurs ( $\pi \alpha \varrho a ́ \kappa \lambda \eta \tau o \varsigma)$. In 1 Foh. 2.1, Tertullian uses aduocatus ${ }^{5}$, just as the Vulgate does; and if he translates Foh. 14.16: '..et alium aduocatum mittet..'6, Paracletus occurs just before and after this passage; indirectly referring to $\mathcal{J} 0 h .14 .16$, Tertullian uses Paracletus ${ }^{7}$; and Joh. 16.7 is translated with an implicit gloss which he had, of course, from John: 'Paracletum, deductorem omnis ueritatis...'8 The word has a special connotation for Tertullian in his later period.

proselytus. An implicit explanation of the term is given in a discussion of an Old Testament passage. ${ }^{\circ}$

serpens. Wd have already seen a passage where Tertullian reflects on the deeper meaning of serpents in Scripture. ${ }^{10} \mathrm{He}$ elsewhere explains this imagery and symbolism ${ }^{11}$; typical is the gloss: '..a serpentibus id est ab angelis diaboli.'12

uas. A comment on Paul's use of this word and the biblical image ${ }^{13}$, language with which he is not wholly in agreement.

uia. Tertullian is aware of the special character and value of the word

1 'Sed malo hunc usum ad scripturae testimonium deputare.'; de uirg. uel., ibid.

2 de monog. 8. 5-8.

3 de orat. 21. 2-4; 22. 1-4. See: Christine Mohrmann, Muliet: à propos de II Reg. 1, 26, VC 2(1948), p. 117-119 (= ELC III, p. 269-271): The problematic of Augustine, for whom mulier meant a woman who was no longer a virgin, is different.

In this connection, see the article of J. MassingBero FORD, The Meaning of 'Virgin', New Testament Studies 12 (1965-66), p. 293-299. Ford suggests the curious use of virgo in de uirg. uel. 11.2, 9.2, (castit. 1.4), as being due to Jewish usage; see p. 297. We will have occasion to return to the question of possible Jewish influences on Tertullian in the second and third chapters.

4 de ieiun. 13.5. s de pudic. 19.16. $\quad$ adu. Prax. 9.3.

7 adu. Prax. 25.1. B adu. Prax. 2.1.

- adu. Marc. 3. 21.2-3, departing from Is. 42.4.

10 See supra, p. 29; adu. Marc. 4. 24.10.

11 adu. Marc. 3. 18.7; de tesurr. 28.2. 12 de idol. 5.4.

13 de resurt. 16.10-12. 
uia, which already appears in Acts $(9.2 ; 19.23 ; 24.14,22)$. He comments '..alias enim uia cognominatur disciplina nostratum..."1; '..cum "uiam" fidem demonstret..'2; '..adeo uiam sectam et disciplinam intellegere debemus...'3

Tertullian also comments upon words which are used by Christians, with relation to biblical words, yet not always taken immediately from the Bible. They, too, are in usu. A good example is the terminology moechia et formicatio in the de pudic. Tertullian departs from his own ordinary usage (stuprum and adulterium) to adapt himself to this language which is in usu. The titles of biblical books, which tend to remain, even when the books are translated, are sometimes simply given: as '..in Basiliis..', '..in Arithmis..'5. Citing Proverbs, however, Tertullian glosses, and suggests a different usage: '..in prouerbiis Salomon, quae

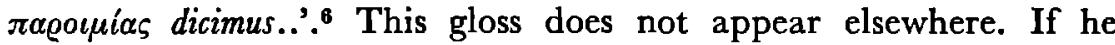
glosses the name of a biblical institution: '..constituit super illos deus critas, quos censores intellegimus..'4, and perhaps the names of the books, 7udges and Kings: '..annales critarum et deinceps regum.. ${ }^{7}$ These glosses in the scorp. are perhaps to be explained by the fact that Tertullian is addressing himself to the rudes and simplices; the de pudic. gloss by different usage. But this is not clear. Tertullian refers to Proverbs, in the ad nat. as Salomon, Solomon: 'enuntiatio Solomonis...88; '..uoce Solomonis..'9, again in scorp. Two comments in the apol. are interesting. That the Christians call one another brother is worthy of comment and defence ${ }^{10}$; the agape, without being named, is explained: 'Cena nostra de nomine rationem sui ostendit: id uocatur quod dilectio penes Graecos.'11 The first group of words were directly biblical; in this second group, we have to do with language which is other than non-Christian usage, or which shows a certain specialisation within the Christians. In both groups, it is the glosses of Tertullian to which attention is primarily drawn here. Tertullian goes on to comment on the following words:

aenigma. A word from the technical vocabulary of exegesis which he uses, Tertullian feels the need to set this word out by way of synonyms like parabola, figura, allegoria; or he glosses it, as: '...in ueritate, - et non in aenigmate, id est non in imagine..'12

allegorica. We here anticipate a difficult text from the adu. Marc. Here we may note only that Tertullian glosses the word, which is central in

1 de orat. 11.2.

${ }^{2}$ adu. Marc. 4. 24.11 ; cf. 3. 21.3; 4. 31.6, also.

a de idol. 9.5. ${ }^{\circ}$ adu. Marc. 4. 14.6.

1 adu. Marc. 4. 23.10; 28.8; scorp. 3.4. 5 de pudic. 18.3.

- scorp. 3.6. 7 scorp. 3.7. ${ }^{8}$ ad nat. 2.2.3.

- scorp. 7.1. 10 apol. 39.8-9. 11 apol. 39.16.

12 adu. Prax. 14.6. 
his polemic with the Marcionites, with an explanation: '..id est aliud portendentia..'1

carnalia. Speaking of different types of sins, Tertullian says: '..quaedam esse carnalia, id est corporalia.."2

ecstasis. This is an interesting example of a word which is biblical in origin (Gen. 2.21 and ff.), but which assumes added significance for Tertullian the Montanist. It is used to express that state, '..amentiae instar..'3 which characterises true prophecy. Tertullian glosses this word several times: '..ratione qua defendimus in causa nouae prophetiae gratiae ecstasin, id est amentiam..'4; '..in ecstasi, id est in amentia.. ${ }^{5}$ The passage Gen. 2. 21-24 (with its interpretation in Eph. 5.31-32) is basic to the development of the theory of prophecy, as Tertullian outlines it in the de anim. Thus we find an implicit explanation: '.. ecstasis super illum, sancti spiritus uis operatrix prophetiae...', and setting forth what Tertullian identifies as a sententia Christiana on the forms and natures of sleep, he explains the term, which is so important for him as Montanist: 'Hanc uim ecstasin dicimus, excessum sensus et amentiae instar..?

Amentia, used to gloss the word, is far more general, of course. ${ }^{8}$ This word therefore is far more than a simple transliteration from the Greek of Gen. 2.21; it is based on that passage, but has become a specialised term within the Montanist group, and Tertullian is always careful to explain it. ${ }^{\theta}$

haeresis. '.. haereses dictae graeca uoce ex interpretatione electionis..'10; an etymological gloss.

instrumentum. Tertullian favors this word to refer to the scriptures. ${ }^{11} \mathrm{He}$ 1 adu. Marc. 5. 4.8. See infra, p. $54 \mathrm{ff}$.

2 de paenit. 3.3. See: Christine Mohrmann, Tetrullianus: Apologeticum en andere geschriften, note $b$, p. 280, ad loc.

s de anim. 45.3.

- adu. Marc. 4. 22.4, commenting on Luc. 9.33.

5 adu. Marc. 5. 8.12. ${ }^{8}$ de anim. 11.4.

7 de anim. 45.1. Cf. J. H. WAszink, De Anima, p. 481-483.

B cf. ad nat. 2. 14.14; de bapt. 5.4; de carn. 16.1.

- For Gen. 2.21, the Vetus Latina offers variant renderings: soporem, ecstasin, stuporem, somn (i)um, mentis alienationem, many of which are allusive and explicative of the locus, rather than true translations. On the pains which Augustine takes to explain ecslasis to his audience, see: Christine Mohrmann, Die altchristliche Sondersprache in den Sermones des hl. Augustin, (LCP 3), Nijmegen, 1932, p. 177-179.

${ }_{10}$ de praescr. 6.2. As in the case of Christus, Christianus (see supra, p. 30), Tertullian likes etymological glosses and explanations. See, for example de resurr. 18.8: '..a cadendo cadaver enuntietur...', etc.

11 On instrumentum in Tertullian, see ReNÉ Braun, Deus Christianorum, p. 463-473. According to Braun, the term is not the invention of Tertullian, and, from its correlation with the Old Testament in the uses of Tertullian, as from other evidence, Braun suggests that its roots are in Latin Jewish usage. Instrumentum seems to decline in use in the later works of Tertullian. 
glosses it, however, as he knows that in the context of the polemic with the Marcionites, testamentum is more usual: '..instrumenti uel, quod magis usui est dicere, testamenti..'.1 To this text, also, we shall have occasion to return in the discussion of the adu. Marc.

oikonomia. A famous theological word, ${ }^{2}$ which Tertullian explains: '..dispensatione, quam oikonomiam dicimus...'

paenitentia. It is well known that Tertullian felt the change of meaning in this word as used by Christians. For the non-Christian, paenitentia means '..passionem animae quandam...quae obueniat de offensa sententiae prioris.."4 Now Tertullian exaggerates the difference in meaning, when he mocks the pagans for regretting what was well done ${ }^{5}$, but he goes on to note that the specific note of the Christian paenitentia is regret for past evil, and resolution for future improvement ${ }^{8}$. We have seen how Tertullian sets out the Greek word, exomologesis, which was used by Latin speaking Christians.

paenitentia and paenitet cause Tertullian some difficulty later, in the discussion with Marcion. The latter, Tertullian feels, has badly understood the nature of the divine 'penitence', and of the expression as used in the Old Testament of God. That divine change of mind does not mean that God is fickle, or improvident of the future; and certainly not that God is guilty of sin. For Marcion understood by paenitentia, '..confessionem..mali operis alicuius uel erroris..' ${ }^{7}$ Tertullian then sets out the meaning of the paenitentia diuina:

Quid ergo erit mos paenitentiae diuinae? Iam relucet, si non ad humanas condiciones eam referas. Nihil enim aliud intellegetur quam simplex conuersio sententiae prioris, quae etiam sine reprehensione eius possit admitti, etiam in homine, nedum in deo, cuius omnis sententia caret culpa. Nam in Graeco sono paenitentiae nomen non ex delicti confessione, sed ex animi demutatione compositum est, quam apud deum pro rerum uariantium sese occursu fieri ostendimus. ${ }^{8}$

Tertullian here appels to the Greek $\mu \varepsilon \tau$ ávoı $\alpha$, which lies behind the idea of paenitentia. Interestingly enough, he uses the normal meaning of paenitet when addressing himself to non-Christians. ${ }^{9}$

1 adu. Marc. 4. 1.1. See infra, p. $44 \mathrm{ff}$.

an oikonomia, see: G. L. Prestige, God in Patristic Thought, London, 1936, reprinted, 1959, p. 57-67; 98-102; Th. VerhoEven, Studien over Tertullianus' Adversus Praxean, Amsterdam, 1948, p. 107-113; Rent BraUn, Deus Christianorum, p. 158-164 et passim; J. MoIngt, Theologie trinitaire de Tertullien, III, p. $891 \mathrm{ff}$.

s adu. Prax. 2.1. 4 de paenit. 1.1. 5 de paenit. 1.5.

- de paenit. 2.2. Tadu. Marc. 2.24.1.

adu. Marc. 2. 24.8.

- ad nat. 1. 1.10, // apol. 14.8, etc. On this, see: S. W. J. TeEuwen, Sprachlicher Bedeutungswandel bei Tertullian, Paderborn, 1926, p. 39-42.

On $\mu e \tau a ́ v o i a$, see: Walter Matzkow, De uocabulis quibusdam Italae et Vulgatae 
The value of confessio and confiteri need not occupy us here, as Tertullian never seems to attend to these words in a reflex way. ${ }^{1}$ pompa. Tertullian comments' on "the word ${ }^{2}$, to explain just what is involved in the familiar word from the baptismal renuntiation. ${ }^{3}$ statio. In his didactic way, Tertullian explains the word by a seeming military origin - to the confusion, we may add, of later philologists: 'Si statio de militari exemplo nomen accepit (nam et militia Dei sumus)..'4 uniuira. This word, a title of honor ${ }^{5}$, is glossed: '..uniuirae, id est nuptae'.

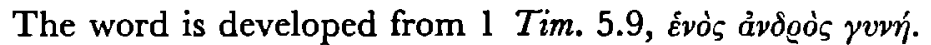

This selection of words which Tertullian glosses is enough to show that he is sensitive to language; that he is aware of the peculiarities of biblical, and of Christian language; that, with his passion for clarity, he sets out the meaning of these words. Sometimes this is in controversy, to clear the ground for further discussion; sometimes it is with the audience to which he is addressing himself in view; sometimes simply didactic, to make himself wholly clear. There is one final text which requires comment.

In the de test. an., Tertullian says: 'Tanto abest, ut nostris litteris annuant homines, ad quas nemo uenit nisi iam Christianus." What are we to make of this text? It is uncertain whether Tertullian means the Bible here,

Christianis, Berlin, 1933, p. 29-35; A. D. Nock, Conversion, first published, 1933; reprinted, Oxford, 1952.

1 On confessio and confiteri: S. W. J. TeEuWEN, Sprachlicher Bedeutungswandel bei Tertullian, p. 74-87; Harry Janssen, Kultur und Sprache, (LCP 8), Nijmegen, 1938, p. 150 ff.; HaNs Rheinfelder, Confileti, confessio, confessor im Kirchenlatein und in den romanischen Sprachen, Die Sprache, 1 (1949), p. 56-67; Chrustine Mohrmann, Quelques traits caractéristiques du latin des chrétiens, Miscellanea Mercati, I, p. 937-966 (= ELG I, p. 21-50; p. 30-33); on confessio nominis in Tertullien, see ELC III, p. 345-346. Since we are dealing with glosses, it is well to comment to the seeming gloss of confiteor in adu. Marc. 4. 25.1. Citing Luc. 10.21 (// Matth. 11.25), according to the Marcionite edition, Tertullian gives the text as: 'Gratias enim, inquit, ago et confiteor, domine caeli...' G. Q. A. MEERshoex hesitates, and wonders if the gratias ago is to be understood as explicative of confiteor. If it were so, we would have a good testimony that Tertullian felt the otherness of the biblical confiteor. But in the establishment of the text of Marcion, we have the independent witness of Epiphanius, who, as usual with him, gives the words or differences peculiar to Marcion; and in Luc. 10.21, Epiphanius gives the single word $\varepsilon \dot{\gamma} \chi \alpha \varrho i \tau \tilde{\omega}$. See Panarion haer. 42.11.6, schol. 22 (Karl Holl, GCS 31, p. 110, 1.9-11); also, A. von HaRnack, Marcion: das Evangelium vom fremden Gott ${ }^{2}$, Berlin, 1924, p. 205*-206*. G. MeErshoek, Le latin biblique d'apres saint Jerôme, p. 76. It is not, therefore, a gloss of Tertullian upon confiteor, but the reflection of the text of Marcion-Luke with which we have here to do.

2 de spect. 7.2; de coron. 13.7; de idol. 18. 7-8.

- On pompa, see: P. de Labriolle, Pompa diaboli, Archivum Latinitatis Medii Aevi

2 (1925-26), p. 170-281 ; J. H. WAszink, Pompa diaboli, VC 1 (1947), p. 15-43.

4 de orat. 19.5; of. de ieiun. 10.6.

s Cf. S. W. J. Teeuwen, Sprachlicher Bedeutungswandel, p. 125.

- de uirg. uel.9.3. 7 de test. an. 1.4. 
or the works of his apologist predecessors - and his own. Harnack takes the text to mean the Bible. ${ }^{1}$ This is in fact attractive, although the context is against it. Karl Holl puts the text into the whole context of the de test. an.: the concern of Tertullian to find a new locus of argumentation, more trenchant than the literary argument, the appeal of the apologists. It would therefore indicate once again that basic scepticism of Tertullian, so evident in his attitude to the Bible itself. ${ }^{2}$ Prof. Mohrmann takes the text to refer to the incomprehension with which Christian texts were greeted, owing to their specialised vocabulary; the distance between Christian Latin and ordinary Latin being already great enough that the spread of Christian works among the pagans was thereby inhibited. ${ }^{3}$ None of these views is sufficient to enable the use of this text to indicate Tertullian's consciousness of the otherness of biblical and Christian language.

Whatever the correct interpretation of the de test. an. text, it is clear from the examples of biblical and Christian language adduced above, that Tertullian is in fact aware of the singular character of that language. Many of these words clearly are not of his own choosing. They are in usu; he comments on them, uses them even without comment, is clearly under their influence. Depending on the audience to which he addresess himself, he glosses them with explanations.

All of this is said not alone for the intrinsic interest, for the view which it gives us of Tertullian's attitude toward this language, but also by way of prologue to the texts from the $a d u$. Marc., which have been thought to indicate that Tertullian did - or did not - read his New Testament of Marcion in Latin. The view we have just had of Tertullian the glosser will be functional in this discussion. The formulae with which he glosses are to be noted:

he comments on the elegance of certain biblical phrases, and comments on imagery and expressions which are characteristic of the Bible with the covering remark: eleganter, in scripturis.

When he is aware than an expression is peculiar to the Christians, or that it is used by a group within the Christian larger group - and whether this differentiation be regional or ideological in origin, is 1 A. Harnack, Tertullians Bibliothek christlicher Schriften, SbDAWB 1914, p. 306-307. On litteris see Rent Braun, Deus Christionorum, p. 459, and note 2 ibid.

2 Karl Holl, Tertullian als Schriftsteller, Gesammelte Aufsätze zur Kirchengeschichte, III, p. 4.

3 Christine Mohrmann, Le latin commun et le latin des chrétiens, VC 1 (1947), p. 1-12 (= ELC III, p. 13-24; p. 21). See, for a disagreeing comment on this opinion: Gart Becker, Tertullians Apologeticum, Werden und Leistung, Munchen, 1954, Exkurs I, p. 338-339. Becker seems to limit the special character of Christian language too much, however. 
difficult to say - his glosses tend to be expressed with the words: dicimus, intellegimus, in usu, in usu nostrorum.

Those of the words which do not seem perfectly clear to the audience, for whatever reason, are glossed with comments introduced by: id est, uel.

We have seen examples of all these expressions in the words which have been examined in the preceding pages. This classification is not meant to be rigid and exclusive. Tertullian's glosses and explanations of words and expressions give us an insight into his attitude toward biblical and Christian language. They are a sign that Tertullian feels that some words are in need of an explanation. This will be a valuable insight, and a fresh point of view from which to deal with the 'classic' texts from the $a d u$. Marc.

\section{TeXts FROM The adu. Marcionem}

After a review of opinions on the question: did Tertullian know a Latin translation of the scriptures? - we have seen two groups of texts from Tertullian, most of which are usually discussed in this relation. The second group of these texts was characterised by Tertullian's commenting upon language which was already in usu. This language is clearly not his own. It represented biblical renderings, sometimes of texts which, like $\mathcal{F}$ oh. 1.1, were very often cited. These indications of biblical versions do not bring us farther than partial renderings of important texts. The discussion of moechia and fornicatio in the de pudic. supplied us with a good indication why Tertullian, for some texts at least, varied his scriptural citation language.

We come now to the adu. Marc., where, as will be seen, Tertullian does a great deal of glossing. The discussion about the language in which Tertullian read his Marcionite New Testament requires a separate review of opinions, by way of introduction.

\section{Opinions: adu. Marcionem}

As we read the adu. Marc., the interpellations of Tertullian are so much in the manner of a living debate between two opposed, personal views, that we tend to forget that Marcion and his activity were already some time in the past, and that Tertullian is now dealing with Marcionites. Marcion himself, the Ponticus nauclerus, as Tertullian sneeringly refers to $\mathrm{him}^{1}$, came to Rome about 140 A.D., and there broke with the

1 As Hermogenes is always the painter, (adu. Hermog. 1.2 ; 36.2 ; 38.1 ; de monog. 16.1) Marcion is always the (Ponticus) nauclerus (de praescr. 30.1; adu. Marc. 1. 18.4; 3. 6.3; 4.9 .2 ; 5. 1.2). See: A. von Harnack, Marcion, p. 25 and note 2 ibid. 
Church. His teaching announced a radical separation between the Law and the Gospel, between the God of justice, and the unknown God of love whom Jesus revealed, as wholly new. Marcion's interpretation of the Old Testament was a strictly literal one and here he is in strange agreement with the Jewish view of exegesis; von Harnack suggests that Marcion had a good acquaintance with Judaism and its teaching. In all events, the total discontinuity between Old and New Testaments was common teaching of Jews and Marcionites, for very different reasons. Against both, Tertullian is careful to defend the principles of allegorical interpretation - more, perhaps, than his own rational, reflective exegesis normally admits. ${ }^{1}$ Tertullian's polemic against Marcion shows many points of agreement with his anti-Jewish arguments. In that great problematic of the early Christian centuries, the relation of the two testaments, Marcion took the radical course: complete separation. To effect this, Marcion first composed his Antitheses. This work, a propaideutic to his New Testament, consisted of a collection of anomalies and contradictions within the Old Testament itself, where the God of justice was seen to be fickle and improvident; and between the teaching of Jesus in the New Testament, revealing a God of love, and the Old, which speaks of the creating God of the world, a god of justice. Marcion's New Testament found its inspiration in Paul's teaching of freedom, over against the Law; and was made up of an edition of Paul's epistles, and a gospel based on what we call canonical Luke. The other gospels were evidently too Jewish for Marcion - Matthew certainly so, where the fulfillment of prophecy is so central. These two instrumenta were styled the Apostolikon and Euangelikon. Tertullian deals with them separately: Marcion-Luke in his fourth book against Marcion, Marcion-Paul in the fifth book; these two books form what is, in effect, the first scriptural commentary. ${ }^{2}$

The question which here occupies us is: in what language did Tertullian read his Marcionite New Testament? Theodor Zahn began with Marcion texts to defend his opinion that Tertullian knew no Latin translation of the scriptures; that Tertullian is always translating from the Greek, and that at most an oral tradition of Latin scriptural

1 See adu. Marc. 3. 5.3, defending allegory against Marcion; de resurr. $26 \mathrm{fr}$, against the Jews and others.

- See: E. Evans, Tertullian's Commentary on the Marcionite Gospel, Studia Evangelica (Oxford Congress, "The Four Gospels in 1957" (TU 73) Berlin, 1959, p. 699-705.

On Marcion's importance for the development of the canon of the scriptures, see: John Knox, Marcion and the New Testament, Chicago, 1942; E. G. Blackman, Marcion and his Influence, London, 1948.

s See supra, p. 4-5. 
translation existed. But Adolf von Harnack, in what is still the most important book on Marcion, set out to defend and rehabilitate Marcion, to give an exposition of his doctrine, and to reconstruct his New Testament. In the process, von Harnack had occasion to defend his opinion, already set forth in his Geschichte der altchristlichen Literatur ${ }^{1}$, that Tertullian knew a Latin translation of the scriptures, and that he knew Marcion's Apostolikon, at least, in Latin translation. His book, Marcion: das Evangelium vom fremden Gott $^{2}$, represented a return to an early interest. Fifty years before, von Harnack had written a prize essay on Marcion, the second century religious figure who so attracted his attention: the only independent religious figure of the postscriptural Church, prior to Augustine, and, for von Harnack, an early Luther, a second Paul.s

The primary text for von Harnack in the question of the language in which Tertullian read his Marcion was, naturally, the Apostolikon. Here we find citations of some length, while the Evangelikon is alluded to, and rarely cited directly. In the citations which Tertullian makes of the Apostolikon, von Harnack sees a Latin which is not of Tertullian's own making, but one which bears all the signs of a '..vulgären und gräzierenden, lateinischen Bibelversion'. ${ }^{4}$ This was a relatively new assessment of the language of the Marcionite New Testament in the form in which Tertullian knew it. The almost simultaneous discovery of the prologues of the Pauline epistles, and their apparent Marcionite tinge, commented upon by Corssen and de Bruyne, shook the common opinion that the Marcionite Paul was in Greek at the time of Tertullian; a second factor to call in question this assumption was the generally admitted influence exercised by the Marcionite text on the Catholic text of the West. These two elements were not sufficient, however, and von Harnack felt that he was breaking new ground with a demonstration that Tertullian must have known the Marcionite Apostolikon, at least, in Latin translation. ${ }^{5}$ His arguments were of two sorts. The first category involved stylistic, lexical and syntactical indications. When the opportunity exists to compare them, the renderings found in other works of Tertullian are very different in language and

1 Leipzig, 1893. See Vol. II, 2: Die lateinische Bibel zur Zeit Tertullians und vor ihm, p. $296 \mathrm{ff}$.

${ }^{2}$ Quoted from the second edition. Leipzig, 1924. An older, much less complete book on Marcion is the Dutch work of H. U. MEหвоom, Marcion en de Marcionieten, Leiden, 1888.

- See Hans von Soden, in a review of von Harnack's Marcion, ZKG 40 (1922), p. 195.

-Marcion", p. 53*. S Ibid., 47*. 
style to the citations which he makes of the Apostolikon. A second group of arguments makes use of proofs drawn from those citations which can be explained only be assuming a Latin text, and from the reflections which Tertullian makes upon the wording of some citations. These reflections would lead one to suppose that Tertullian is not the translator, but is in contact with language which requires explanation.

Hans von Soden, who found the arguments of von Harnack irrefutable, developed the first group of his arguments in a systematic way. A lexical comparison of the citations made from Marcion-Paul in the fifth book Against Marcion with those which Tertullian elsewhere makes from Paul would lead to the conclusion that Tertullian did in fact read his Marcion-Paul in Latin, a Latin which is quite different to that of the Pauline citations in the other works of Tertullian. ${ }^{1}$

The Utrecht dissertation of Gilles Quispel, however, called the conclusions of von Harnack into question. The main intent of this book ${ }^{2}$ is the tracing of the sources of the adu. Marc., and the formulation of a theory on how it came to assume the form which it now bas. In his sixth chapter, Quispel negatively criticises the findings of von Harnack. He there would show that the arguments of von Harnack are not at all as convincing as they had been thought to be. His main attention is on the adu. Marc., although he does consider some texts elsewhere in Tertullian. For the adu. Marc., Quispel proceeds as follows:

a. Some examples are cited which show that Tertullian is translating from the Greek.

b. Investigating the biblical citations from Paul in the fifth book, it appears that they are related to the 'African' translation which Tertullian must have known. Now, if Tertullian knew the Marcionite Bible in Latin, then it is difficult to see why it should show this affinity with the African version of the orthodox North African church. In all events (for Quispel's arguments here are essentially negative) it is for those who claim that the Marcionite New Testament was known to Tertullian in Latin to show why this supposed translation should display a relationship with the Latin translation of the local church. For Quispel, it is natural to assume that Tertullian, the active translator of the Marcion texts, was influenced by the current translation which he knew in his church.

c. Some citations in Marcion, and these same citations in the forms in which they appear elsewhere in Tertullian, depart from all known biblical Latin translations. Whence it appears that Tertullian is the translator in both instances.

d. The linguistic arguments of von Harnack are examined, and, where possible, refuted.

e. Other arguments of von Harnack - those texts where Tertullian seems to reflect on texts, and where he seems to improve, defend, or explain a translation - are examined and refuted.

1 Hans von Soden, Der lateinische Paulustext bei Marcion und Tertullian, Festgabe Jülicher, Tübingen, 1927, p. 229-281. (Also published as a separate monograph, under the same title, Tübingen, 1927).

2 Gilles Quispel, De Bronnen van Tertullianus' Adversus Marcionem, Leiden, 1943. 
f. The general conclusion of Quispel is this: Tertullian is the active translat or from the Greek of Marcion's New Testament. His translation reflects the influence of other Latin translations which he knew, in its choice of language. ${ }^{1}$

Quispel certainly damages the arguments of von Harnack. He catches him out in the misinterpretation of texts ${ }^{2}$; Braun ${ }^{3}$, however, comments that it is not possible to accept his arguments in full, and this is a judgment with which one can concur. Quispel was not able to take the von Soden study into account; he mentions this in a note at the end of his book, stating that he is in disagreement with the method and the conclusions of von Soden. While not the main purpose of the work, the remarks which Quispel makes on the texts and arguments of von Harnack remain an important corrective.

A. J. B. Higgins ${ }^{4}$ attacked the problem for Luke. This is vastly more difficult, given the allusive character of the Lucan references in the fourth book against Marcion. The conclusions of this study agree 'exactly's with the work of von Soden. Tertullian is using two translations, one of which shows clear European character. This cannot be explained by supposing Tertullian himself to have been the translator of Marcion-Luke; it is, in fact, a translation which shows greater affinity with the European tradition than that which Tertullian shows, in his other citations of Luke, with the African tradition. It also has distinctive and independent features.

\section{The Marcion Texts}

After this briefest of reviews of opinions on an extremely complicated question, we come to a number of texts from the adu. Marc. One must first of all observe that the critical edition of the adu. Marc. with which we must work is defective. A new one is being prepared ${ }^{6}$; but until its publication, citations have to be made from the Kroymann edition, with the awareness of the faults of this text.

1 Quispel, De Bronnen, p. 104-105.

9 Notably, adu. Marc. 4. 14.1; De Bronnen, p. 88-89. von HarNack interprets this of Marcion, but it refers to Christ. Also, the interpretation of Luc. 5.36, where von Harnack's etiam is an addition; see von Harnack, Marcion ${ }^{2}, 292^{*}$.

- Deus Christianorum, note 1, p. 21: "La these de G. Quispel.... qui pensait avoir montré contre Harnack que T. avait traduit directement des citations du grec de Marcion..ne peut plus être soutenue telle quelle."

- A. J. B. HrgGins, The Latin Text of Luke in Marcion and Tertullian, VC 5 (1951), p. 1-42. G. J. D. AALDERs studied the citations of Luke in Tertullian, outside the adu. Marc.: Tertullian's Quotations from St. Luke, Mnemosyne III 5 (1937), p. 24I-282.

- Higgins, The Latin Text of Luke in Marcion and Tertullian, p. 42.

- Claudio Moreschin, of the Istituto di Filologia Classica, Università degli Studi di Pisa is presently working on a new critical edition of the adu. Marc. 
The texts with which we are dealing here have been cited by authors generally, and by von Harnack specifically, in the effort to show Tertullian's knowledge of a Latin translation of the scriptures, or of Marcion-Paul, at least. We are on well-worn grounds, therefore. But these texts will be discussed in continuity with the argument up to now; Tertullian is sensitive to language, to biblical and Christian language in particular, and he glosses the strange and the unfamiliar with a more general word. From this vantage point - Tertullian as glosser - a new view may be had of the classic Marcion texts, and in them we may see more examples of Tertullian's awareness of language which is other.

1. adu. Marc. 3. 24.3.

(Phil. 3.20)

Nam et confitemur in terra nobis regnum promissum, sed ante caelum, sed alio statu, utpote post resurrectionem in mille annos in ciuitate diuini operis Hierusalem caelo delatum, quam et apostolus matrem nostram sursum designat. Et politeuma nostrum, id est municipatum, in caelis esse pronuntians, alicui utique caelestr ciuitati eum deputat.

This text is not part of the commentary which Tertullian makes on Marcion-Paul. It seems best, however, to take this passage in the context of the Marcion problematic. We find a gloss here: politeuma seems in need of explanation, which is given with municipatus. politeuma occurs nowhere else in Tertullian, although we do find an interesting text in ad mart. ${ }^{1}$ :

Bonum agonem subituri estis in quo agonothetes Deus uiuus est, xystarches Spiritus Sanctus, corona aeternitatis, brabium angelicae substantiae, politia in caelis, gloria in saecula saeculorum.

Tertullian seems here to have the Philippians text in mind. The reference brabium indicates Phil. 3.14, and politia Phil. 3.20. The Greek of Phil. 3.20 gives $\pi 0 \lambda i \tau \varepsilon v \mu \alpha$, with no variants. ${ }^{2}$ Elsewhere, after the two texts just cited, Tertullian refers to Phil. 3.20 with municipatus: '..noster, inquit, municipatus in caelis...'3; '..et quidem de terra in caelum, ubi nostrum municipatum Philippenses quoque ab apostolo discunt....'4; '..noster, inquit, municipatus in caelis..'5. Tertullian then, seems to show a hesitancy in translating, in his early period; allusively, politia, in ad mart.; then the virtula transliteration politeuma, glossed immediately with the rendering which then dominates: municipatus. What are we to make of this text?

1 ad mart. 3.3.

2 Tertullian uses the word politia in one other place, citing the Republic ( $\pi 0 \lambda_{\iota} \tau \varepsilon l \alpha$ ) of Plato: ‘..in Politia..'; de anim. 51.2.

s adu. Marc. 5.20.7. A de resurr. 47.15. 5 de coron. 13.4. 
Von Soden thought that Tertullian found municipatus in his Latin Marcion, and that the Latin translation of the orthodox local church which he knew gave politeuma. He would then explain the de coron. text just cited as '..Umschreibung Tertullians.' normal translation of his church. He does not consider the text from de resurr. This seems unsatisfactory.

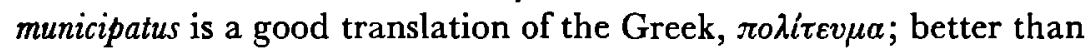
the more widely used conuersatio. Tertullian does use conuersatio as a translation of $\pi 0 \lambda \iota \tau \varepsilon i \alpha$ in Eph. 2.12 $2^{2}$, citing the Marcionite version - in whatever language - of Ephesians. Our vulgate uses conuersatio, however, to translate $\pi$ di $i \varepsilon \varepsilon v \mu \alpha$, as does Cyprian ${ }^{3}$, the testimonia ${ }^{4}$, and Augustine. Jerome however ${ }^{\mathbf{5}}$ gives both municipatus and conuersatio. That Jerome should have used municipatus is a problem for Bede, who comments ${ }^{8}$ :

..quod alibi Apostolus ait, nostra conuersatio in caelis est, quidam interpretati sunt, noster autem municipatus in caelis est. 3. Hieronymus ad Heliodorum scribens ita posuit quia non aliud municipatum quam ciuilem conuersationem,

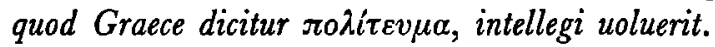

Bede himself, who is found of the passage, uses conuersatio elsewhere. Jerome's usages, and Bede's comment on Jerome shows us that conuersatio and municipatus co-existed in the early tradition of Latin translation. But nowhere in that tradition do we ever find politeuma. This is not to say that it could not have existed in some early, partial translation, just as amartiis in the de bapt. text with which we began this chapter. But the complete lack of other witnesses to politeuma suggests that Tertullian is still hesitating at this point; that he transliterates the Greek word, whose exact value is appreciated by him, and which is important for his argument in adu. Marc. 3. 24.3; and that he then gives municipatus as the glossing translation. This theory accounts for politeuma. It does not belong to the tradition of old Latin biblical translations, but simply shows that Tertullian knows, and appreciates the Greek original. The source of municipatus, however, is more difficult.

1 von Soden, Der lateinische Paulustext, p. 252.

2 adu. Marc. 5. 17.12. Tertullian uses contersatio here, and in the following section, 13, four times. He also uses the word frequently in the general sense of behavior, elsewhere.

3 de mortalitate 22 (G. Hartel, CSEL 3,1, p. 311, 1.3).

- test. 3.11 (Hartel, CSEL 3,1, p. 124, 1.4).

5 Jerome, comment. in Amos, PL 25, col. 1035; ep. 16. 2.3 (I. Hilberg, CSEL 54, p. 69, 1. 20) ; ep. 58. 2.3 (Hilberg, CSEL 54, p. 530, 1.3); ep. 60. 3.4 (CSEL 54, p. 552, 1.7); this last use being the one on which Bede comments; ep. 120. 8.8 (Hilberg, CSEL 55, p. 491, 1.20). In these references, Jerome uses municipatus. For conversatio, see: comment. in Ep. ad Eph., PL 26, col. 445; col. 468; adu. Iouian., PL 23, col. 265; 278; 297, etc.

- Bede, Expositio Actuum Apostolorum et Retractatio (M. L. W. Laistner, Cambridge, $1939,142,1)$. 
It would be natural to assume that he comes in contact with a translation - in all probability, a translation of Marcion-Paul - and that he thenceforth adopts it. But this depends on the answer that one gives to the question: did Tertullian read his Marcion-Paul in Latin? There is no doubt that Tertullian knows and controls the Greek of his biblical citations. How much he depends on a Latin translation here is problematic. The evidence brings us no farther than this.

\section{2. adu. Marc. 4. 1.1}

Omnem sententiam et omnem paraturam impii atque sacrilegi Marcionis ad ipsum iam euangelium eius prouocamus, quod interpolando suum fecit. Et ut fidem instrueret, dotem quamdam commentatus est illi, - opus ex contrarietatum oppositionibus 'Antithesîs' cognominatum et ad separationem legis et euangelii coactum - qua duos deos diuidens, proinde diuersos ut alterum alterius instrumenti uel, quod magis usui est dicere, testamenti, exinde euangelio quoque secundum antithesis credendo patrocinaretur.

On the threshold of his commentary on the Marcionite New Testament Tertullian names the paratura of Marcion: the interpolated Luke, and the propaideutic to it, the antithesis. We have already seen this text briefly, as an example of Tertullian's glossing technique, ${ }^{1}$ This text is frequently cited by authors as a key text in the problem of the Latin scripture translation and Tertullian, even apart from the special question of the adu. Marc.

As is usual, the interpretations of the text vary. ${ }^{2} \mathrm{We}$ may first of all note that antithesis is here implicitly glossed with the covering comment: '..ex contrarietatum oppositionibus.' This gloss is more explicitly given earlier: 'Nam hae sunt "Antithesis" Marcionis, id est contrariae oppositiones..'3 This latter text is parallel to the opening of chapter four. Tertullian goes on to say, earlier: '.. quae conantur discordiam euangelii cum lege committere, ut ex diuersitate sententiarum utriusque instrumenti diuersitatem quoque argumententur deorum. ${ }^{4}$

Now, if in this earlier text, Tertullian calls Marcion's book an instrumentum, as he calls his books here in book four paratura, there is no doubt but that these are words of Tertullian. ${ }^{5}$ Antithesis is just as clearly a word of Marcion, and it appears only in the adu. Marc. Tertullian, with his eye for clarity of terminology, remembers to explain antithesis, and he remembers also that 'his own' word, instrumentum is not the

1 p. 34, supra.

2 De Labriolle, art. cit., Rönsch, Itala und Vulgata, p. 4, Aalders, De Citaten, p. 12, QuisPel, De Bronnen, note 1, p. 137, all cite this passage in diverging interpretations. ${ }^{3}$ adu. Marc. 1. 19.4. I Ibid.

5 See René Braun, Deus Christianorum, p. 463-473, for instrumentum; ibid., paratuta. 
usual word for the two testamenta. As we will see, testamentum is not a word that Marcion would have favored. It would appear that this text tells us nothing about the language of Marcion's New Testament, as Tertullian knew it. There is in fact an adjustment of language, where language which is normal in Tertullian's church, and that which is normal to the Marcionite group are explained to one another. Usus certainly refers to traditional language within the orthodox church, but it does not at all prove that the testamenta were therefore translated into Latin. Tertullian had earlier described Marcion's aim, that of separating the New Testament from the Old, using the word testamen$t u m^{1}$, and Tertullian was there using traditional language. If instrumentum, $-a$ continues to be used throughout the works of Tertullian, we note that testamentum, apart from its frequent use in the adu. Iud., occurs much more frequently in his later works. It is massively used in the fourth book against Marcion, and fairly regularly thereafter.

This text can tell us nothing of Marcion's text, and the language in which Tertullian read it. It does give us another example of the care which Tertullian has for absolute clarity of language; and, in the adu. Marc., this concern is seen in a constant adjustment of language in two directions - to prejudge the case for a moment: explaining Marcion's usage to the orthodox church, and explaining language which was traditional within the church to the Marcionites.

\section{3. adu. Marc. 4. 8.4 (Matth. 8.17; cf. Is. 53.4)}

Ipse igitur est Christus Esaiae, remediator ualetudinum: hic, inquit, imbecillitates nostras aufert et langores portat. Portare autem Graeci etiam pro eo solent ponere, quod est tollere.

We have here to do with a text which has never been central to the discussion, but which, nonetheless, is revealing. It is first of all interesting that Tertullian, while he explicitly appeals to Isaias for this testimony (for such it is), seems to cite the text much as Matthew does, where Matthew seems to translate from the Hebrew, rather than cite the LXX of Is. 53.4. Tertullian, as we will see follows the species curationum (adu. Marc. 4. 8.4) through Marcion-Luke, to prove that the Christ there represented is the Christ promised by Isaias. For this argument, the portare of the citation seems inadequate, open to misinterpretation. Tertullian therefore explains the word by the Greek which lies behind it: $\dot{\varepsilon} \beta a a^{\prime} \tau \alpha \sigma \varepsilon v$. The use of portare in this context is traditional in the Vetus Latina. ${ }^{2}$ Tertullian, who returns to this text

1 de praescr. 30.9 .

2 See, for example: test. 2.13 (Hartel, CSEL 3,1, p. 77, 1.20); Cyprian, de lapsis 17 
several times', seems to be dissatisfied with the word, and, knowing that the text would be either unknown to, or unacceptable for his adversaries, he explains its language. As we will have occasion to remark on several other texts, this tells us nothing of the language of Marcion. Rather, this would seem to point to Tertullian's awareness that portare, used in this connection, was language peculiar to a biblical translation, and open to ambiguity. While not a passage to be insisted upon, this reflection of Tertullian does seem to be characteristic of his glossing technique in the adu. Marc., and, as such, instructive.

\section{4. adu. Marc. 4. 11.12 (Ps. 77.2; cf. Matth. 13.35)}

Nec forma sermonis in Christo noua. Cum similitudines obicit, cum quaestiones refutat, de septuagesimo (septimo) uenit psalmo: aperiam, inquit, in parabolam os meum, id est similitudinem; eloquar problemata, id est edisseram quaestiones.

A much quoted text. Capelle ${ }^{2}$ sees in it an indication that Tertullian knew a Latin translation of (a part of) the Bible. Friedrich Stummer's reasoning is characteristic of the view that Tertullian did know a translation of the scriptures into Latin: ${ }^{3}$

Hier liegt der Fall ganz deutlich. Hätte Tertullian unmittelbar aus dem Griechischen übersetzt, so wäre nicht zu verstehen, warum er nicht gleich den Ausdruck genommen hat, der ihm der treffendste zu sein schien.

Even while he feels that proving Marcion-Luke to have been in Latin to be a more difficult task than is the case for Marcion-Paul, von Harnack cites the passage as an evident proof that Tertullian found similitudo in his Marcion-Luke, ad loc. 5.36. Had Tertullian the Greek text of Luke before him, he would simply have translated $\pi \alpha \varrho \alpha \beta o \lambda \eta$ into parabola. But he is disagreeing with the Marcionite idea that Christ's manner of preaching was wholly new, and he is able to prove that this style of preaching is already predicted in the Old Testament, and he can cite Ps. 77.2 to prove this. ${ }^{4}$

Quispel disagrees with such reasoning, however. ${ }^{6} \mathrm{He}$ very properly points out that this is Tertullian's argument, and nothing can be directly proven as to the language of Marcion-Luke from this passage.

(Hartel, CSEL p. 249, 1.10); $e p .11 .5$ (Hartel, CSEL 3,2, p. 499, 1.10); $e p .63 .13$ (Hartel, CSEL 3,2, p. 711, 1.13). Jerome has portauit regularly, but also fert; and we find suscepit, tulit, etc. in other citations from the Fathers.

1 adu. Marc. 3. 17.5 (portauit); 4.9 .10 (suscepturus).

2 P. Capelle, Le texte du Psautier latin en Afrique, p. 5.

F. STUMmer, Einführung in die lateinische Bibel, p. 12.

- A. von Harnack, Marcion', p. 180*.

- De Bronnen, p. 88-89. 
But the glosses remain unexplained; and it is precisely the glosses of Tertullian which interest us. Tertullian begins, then, with words which would characterise the allegedly new manner of preaching which Christ used: quaestiones, similitudines. He then appeals to Ps.77.2, a text, therefore, which is outside the Marcionite Bible, and then glosses the peculiar words problemata and parabola, as well as others, with more general terms. Before beginning a discussion of these words, the hypothesis may again be suggested: we find ourselves before an adjustment of language, from a Latin translation of the Psalm verse in question, to the Latin version of Luke which Tertullian had before him. Rather than commenting on this text in isolation, it would seem advisable to link it with what appears to be a general phenomenon in the ad. Marc., adjustment of terminologies. With this prefacing observation, some interesting comments can be made upon the words which Tertullian uses here.

Beginning with problemata: closely reflecting the Greek of Ps. 77.2, the word occurs elsewhere in Tertullian only in the singular ${ }^{1}$, and not in biblical citations. What is more interesting, the word never occurs in the old Latin tradition of Latin Psalter translations. ${ }^{2}$ It would appear then, that this is a word much like politeuma, or, again, like amartiis as they occur in the texts which we have seen. This lack of evidence is not conclusive, of course. But we can say nothing about problemata as evidencing a Latin translation upon which Tertullian would have been drawing; and it is obvious that this tells us nothing of Marcion's New Testament. It is curious that Tertullian should use these graecisms, these transliterations; but we know of no places where they occur in Latin translations.

The second word glossed $^{\mathbf{3}}$ is more interesting. Parabola is explained

1 de resurr. 36.1 ; de fug. 12.1 ; de fato (CC, p. 1333).

2 In the various Psalters, the universal tradition is the pairing parabola/propositiones, with variation only in the singular and plural of both words. Augustine, who has aenigmata in speculum 6 (F. Weihrich, CSEL 12, p. 36, 1. 4-5), also has propositiones, and he reflects on this word, together with parabola, in an interesting parallel: '..propositiones autem quae graece appellontur $\pi \varrho \circ \beta \lambda \eta \mu a \tau a, ~ q u a e s t i o n e s ~ s u n t$, habentes aliquid quod disputatione soluendum sit.' (Enarr. in Ps., Ps. 77 (Dekkers and Fraipont, CC XXXIX, p. 1066). In the same passage (ibid., 1. 20-22), he comments on parabole: 'Parabola quippe alicuius rei similitudinem prae se gerit; quod licet sit uocabulum graecum, iam tamen pro latino usurpatur.' These explanations of Augustine are interesting when placed in contrast with the glosses of Tertullian in the passage adu. Marc. 4. 11.12. Jerome also uses aenigmata, and once comments upon propositiones: 'Pro propositionibus in hebraico habet "aenigmata"...' Tract. in Psalm., Ps. 77 (C. Morin, CC LXXVIII, p. 65, 1.38).

S Eloquar is also glossed, with edisseram; a typically biblical Latin word, with a favorite word of Tertullian. It would only complicate the argument, to introduce 
by similitudo. Tertullian had prepared for this discussion, when, in his third book, he explained he set out the two important characteristics of scripture: prophecy, the announcement of the future as present, and allegory. Tertullian gives various words in which this latter form is expressed: '..per aenigmata et allegorias et parabolas...' Again, he explains parabola: '..genus eloquii a creatore promissum..'.' In the fourth book against Marcion, Tertullian sometimes puts parabola in parallel with similitudo, as if he would be perfectly clear: 'Parabolarum status, similitudinum peraequatio...'3; '..parabolam..similitudinem....' ${ }^{4}$ We may see such an implicit equation again in the de resurr. ', 'De uacuo similitudo non conpetat de nullo parabola non conuenit..'. For all that, Tertullian uses the word parabola rather more frequently in the fourth book against Marcion than he does similitudo: parabola $16 \times$, similitudo (as translation of $\left.\pi \alpha \varrho \alpha \beta o \lambda \eta^{\prime}\right), 9 \times$.

Matthew uses the word $\pi \alpha \varrho \alpha \beta o \lambda \eta \eta^{\prime}$ frequently, as does Luke. Now the striking thing is that Tertullian always translates the Matthaean passages where $\pi \alpha \varrho \alpha \beta o \lambda \eta \dot{~ o c c u r s ~ w i t h ~ p a r a b o l a ; ~ a n d ~ t h e ~ w o r d ~ a s ~ h e ~ u s e s ~}$ it always has to do with a peculiarly biblical form of illustration, or a teaching example. ${ }^{6} \mathrm{~A}$ text where the two words meet is interesting enough to cite: ${ }^{7}$

..ex illius quoque parabolae patrocinio quae bonum semen frumenti a Domino seminatum in primore constituit, auenarum autem sterilis faeni adulterium ab inimico diabolo postea superducit. 2. Proprie enim doctrinarum distinctionem figurat quia et alibi uerbum Dei seminis similitudo est....

The juxtaposition of the words is, perhaps, not fortuitous. The scriptural apparatus of CC notes Marc. 4.3 as the source for the alibi. But this cannot be right; for Luke, and only Luke makes the exact identification: semen est uerbum Dei. Tertullian is perfectly aware that this detail is not in the Matthaean version of the parable, and he therefore crossrefers to another evangelist, Luke, for the explanation of it. This allusive reference to Luke is given with the introduction of the word similitudo. This is, apparently, not accidental. If similitudo in Tertullian has a far greater range of meanings than parabola, still, when it is used as a rendering of $\pi \alpha \propto \alpha \beta 0 \lambda \eta$, it always, with but one possible exception,

this into the text above; but it is another gloss in the complex. Eloquium is always used in Tertullian with relation to biblical, prophetic utterances.

1 adu. Marc. 3. 5.3. $\quad 2$ adu. Marc. 4. 19.2. $\quad{ }^{3}$ adu. Marc. 4. 29.6.

4 adu. Marc. 4. 29.9, of Luc. $12.41 \mathrm{ff}$. B de resurr. 30.5.

- The Matthaean uses of $\pi \alpha \varrho \alpha \beta 0 \lambda \eta \dot{~ a r e ~ c i t e d, ~ o r ~ a l l u d e d ~ t o ~ b y ~ T e r t u l l i a n: ~ 13.3, ~}$ scorp. $11.3 ; 13.10$, de resurt $33.2 ; 13.34,10,13,14$, de resurr. $33.1-2 ; 13.18$, de resurr. 33.5 ; 13.24, de proescr. 31.1; 21.33, adu. Prax. 26.9; he also uses the word in general of biblical examples, and also of Luke.

7 de praescr. 31.1 . 
refers to Luke. There are five categories into which the uses of similitudo can be classified, a general sense of likeness, similarity, comparison, generally without a biblical reference ${ }^{1}$; referring to $G e n .1 .26$, and usually with imago, reflecting an important idea of Tertullian ${ }^{2}$; of the prohibition by the Law of the making of images ${ }^{3}$; of Rom. 8.3. and Eph, $2.7^{4}$; and, finally, in the sense which here occupies us: as a translation of the Greek $\pi \alpha \varrho \alpha \beta o \lambda \dot{\eta}$.

It is natural that the uses of similitudo in the fourth book against Marcion should refer to Luke. Elsewhere, however, a pattern appears which is striking: de praescr. 26.3 speaks of a similitudo, and clearly refers to Luc. 19.20; de praescr. 31.2 to Luc. 8.11; de patient. 12.6; de paenit. 8.4 to the parables of mercy, Luc. 15.4 and ff., all using similitudo. The one exception occurs in de idol. 7.3, where we find similitudo referring to a Matthaean pericope: (Matth. 18.8//Marc. 9.43). This, it is true, is not a parable at all, but the teaching, '..if your hand scandalise you..'. Elsewhere, similitudo, translating $\pi \alpha \varrho \alpha \beta o \lambda \eta^{\prime}$, always refers to Luke. This seems to indicate that Luke has a special profile for Tertullian, even apart from, and prior to the adu. Marc. Lucan parables are also set off quite often with ille, distinguishing those stories which only Luke has.

The Vulgate uses only parabola in translating the passages of Matthew where $\pi \alpha \varrho \alpha \beta o \lambda \eta \dot{~ o c c u r s . ~ I n ~ L u k e, ~ t h e r e ~ i s ~ a ~ h e s i t a n c y ~ b e t w e e n ~ p a r a b o l a ~}$ and similitudo. In the Vetus Latina tradition, looking only at the mss. evidence, the so-called 'Itala' tradition gives us parabola regularly for Matthew ${ }^{5}$; while the 'Afra' tradition hesitates; $k$ gives similitudo usually, $e$ parabola'. In Luke, the 'Itala' hesitates between similitudo and parabola, while the 'Afra' represented by $e$, gives similitudo, in all loci but one: Luc. 8.4.7 The citations in the Latin fathers show the same variety, without a pattern being clear.

1 As in: ad nat. 2. 13.20; apol. 47.11; de bapt. 4.5; de patient. 10.3; de paenit. 4.4; adu. Hermog. 41.1; adu. Marc. 3. 10.1; 4. 18.6; 5. 9.5; de anim. 17.7; adu. Prax. 22.11, etc. 2 Translating the '...kat' $\delta \mu o l \omega \sigma \iota v$ of Gen. 1.26: de bapt. 5.7; adu. Marc. 2. 4.5; 5.1; 5.5; 6.3; de carn. 17.4; de resurr. 6.4; 9.1; adu. Prax. 5.7; 12.4, etc.

Translating $\delta \mu o i \omega \mu \alpha$ of Ex. 20.3, // Deut. 5.8: de spect. 23.5 (in general, of the Law forbidding images); adu. Marc. 2. 8.2 ; 22. 1.2; 3. 18.7; 4. 22.5; de idol. 4.1; 5.3; 5.4.

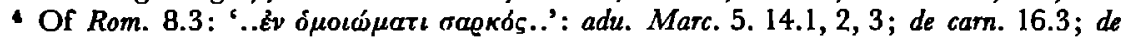

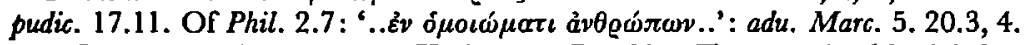

- A. Jülicher, W. Matzkow, K. Aland: Das Neue Teslament in altlateinischer Uberlieferung, Berlin, 1938-1963. Vol. I: Matthäus-Evangelium, A.Jüzıcher, editor, Berlin, 1938. - A. JüLrchrer, op. cit.; $k$ always has similitudo in Matthew, 13.31 excepted, for the loci to which it is a witness; $e$ has parabola regularly, but similitudo in $13.31 ; 13.53$; $15.15 ; 24.32$.

7 A. JüLicher, W. Matzkow, Das Neue Testament in altlateinischer Uberlieferung, Vol. III, Lukas-Evangelium, Berlin, ad loc. 
Returning to the text at issue, then; it is surprising that Hans von Soden identified parabola as European in character, and that he claimed that it had introduced itself into the African tradition. In a context where Matthew is being discussed, von Soden states that Tertullian read similitudo in his 'Latin Bible'; ; quite the opposite is the case. For what concerns Matthew, parabola is always the rule, with but one possible exception; and similitudo always, with that same exception, refers to Luke.

This tendency of Tertullian to use similitudo - as rendering $\pi \alpha \rho \alpha \beta o \lambda \eta^{\prime}$ - virtually exclusively in reference to Luke is slender evidence; but it is of some interest. This pattern is true even outside, and before the adu. Marc. What do the glosses of parabola with similitudo, of problemata with quaestiones, tell us of the language in which Tertullian knew his Marcion-Luke? While problemata lacks confirming evidence from the tradition of old Latin biblical translations, parabola and similitudo are both well represented in that tradition. It looks very much as if Tertullian is in contact with two terminologies. He cites a text which is by definition one foreign to the Marcionite canon. He then explains its language in terms of the Marcionite language, or in terms which were ordinarily used of Luke.

Both quaestiones and similitudines are important in the context of Luc. 5.36; both were presented by Marcion as typifying the wholly new character of his Christ, and Christ's manner of preaching. Tertullian's answer is to root them in the Old Testament. As already noted, Tertullian's polemic with Marcion has a curious similarity with antiJewish polemic of the first centuries; this is paradoxical, since Marcion was strongly anti-Law. And so, in citing the Old Testament, Tertullian is at some pains to make perfectly clear the meaning of the (strange) words of the citation.

This text does not, of itself, prove very much. Taken, however, with the cumulative evidence of the Marcion texts, it does suggest that Tertullian is in contact with two terminologies, which he explains to one another. These texts have been discussed too much in isolation, as single texts; but what unifies them is the glossing technique of Tertullian, and the reason for the glosses.

5. adu. Marc. 4. 14.1 (Luc. 6.20)

Venio nunc ad ordinarias sententias eius, per quas proprietatem doctrinae suae inducit, ad edictum, ut ita dixerim, Christi: beati mendici, - sic enim exigit

1 H. von Soden, Das lateinische Neue Testament in Afrika zur Zeit Cyprians (TU 33) Leipzig, 1909, p. 190. 
interpretatio uocabuli, quod in Graeco est - quoniam illorum est dei regnum. Coming to the Beatitudes, Tertullian has to show that these, the charter of Christ's teaching, are also announced in the Old Testament, and are therefore not nearly so new as Marcion imagines. ${ }^{1}$ He turns to the Old Testament, wondering with which text of the many there to begin. The citations which follow: Ps. 81.3-4 (mendico $\left.=\pi \tau \omega \chi \chi^{\prime} v\right)$; Ps. 71.4 (mendicos $=\pi \tau \omega \chi$ ov́s, pauperum $=\pi \varepsilon v \eta \dot{\tau} \tau v) ;$ Ps. 9. 18-19; Ps. 112. 5-8; 1 Kings 2.8; Is. 3. 14-15; 10. 1-2; 1. 17-18: all find the words mendicus, pauper, and also, egenus, introducing citations from $I s .3 .14-15,10.1-2$; 1. 17-18. Why does Tertullian use mendicus here, and justify it as a good translation of the Greek $\pi \tau \omega \chi o^{\prime} \varsigma$ ?

The text has been cited to found the most opposed interpretations. Zahn used it to show that Tertullian is translating from the Greek ${ }^{2}$ Von Harnack found it a difficult text, and solved the problem in this way: Tertullian found pauper in his Marcion-Luke, but changed this to mendicus in order to have verbal harmony between the teaching of Marcion's Christ, and the literal citations of the Old Testament, where mendicus was found. ${ }^{3}$ This involved explanation founders on the fact that pauper also occurs in these texts, as Tertullian cites them. Von Soden is dissatisfied with this explanation, and thinks rather that Tertullian did in fact read mendicus in his Marcion text, which von Soden supposes to have been in Latin. He then goes out of his way to accept and justify this translation. Theorising that $\pi \tau \omega \chi \delta \delta$ was regularly translated in the Latin translations of the Old Testament to which Tertullian would be appealing as mendicus, von Soden is then able to explain Tertullian's acceptance of mendicus as a translation; it is all the better for his argument. ${ }^{4}$ It would seem natural to assume that Tertullian did in fact find mendicus in the text which he had before him; he has to explain the term, for pauper would have been traditional (or, possibly, egenus: but pauper is better represented in Tertullian). Tertullian is not writing only for Marcionites, obviously. That Tertullian knows, and consults the Greek which is behind Marcion-Luke, and the Greek of the Bible in general, is certain, and agreed upon by all. Just as with parabola, we would find an adjustment of terminology

1 See G. Qutsper, De Bronnen, p. 90.

- See comment of H. von Soden, Der lateinische Paulustext, note 1, p. 238-239.

3. von Harnack, Marcion ${ }^{2}$, p. 180*-181*.

4. von Soden, Der lateinische Paulustext, p. 238-239. A. J. B. Higains, The Latin Text of Luke in Marcion and Tertullian, VC 5 (1951), p. I-42, p. 20, agrees with von Soden that Tertullian is defending mendicus, which he read in his Marcion-Luke, and comments: 'These seem quite clearly to be taken from a Latin Bible.', referring to the Old Testament citations, also. 
here, though without an explicit gloss. What is more, it is only in the $a d u$. Marc. that mendicus appears. This is enough to make one suspect that it is a term strange to Tertullian, and that he found it in the text of Marcion-Luke.

However: mendicus never appears in the tradition of the Vetus Latina, as a translation of the locus, Luc. 6.20, or, indeed, of the beatitudes as given by Matthew or Luke. For Luc. 6.20 in the mss, we find pauper, with only $e$ differing, giving egenus as a translation. Von Harnack claimed that all Latin mss. give pauper; Higgins pointed out that mendicus is not unknown,occurring in Luc. 14.131. But, for what concerns the beatitudes in Luke, mendicus does not appear; and it seems useful to make this distinction. The New Testament $\pi \tau \omega \chi o_{s}$ is not univocal, and Tertullian seems to make a distinction, using egenus of what one might call the economically poor. ${ }^{2}$

Looking at the citations from the fathers, we find a comment from the opus imperfectum in Matth. (of Arian tendency; ca. 550, in Italy), which corrects the usual translation: '.. in Graeco non dicit, Beati pauperes; sed, Beati egeni, uel, Beati mendici...?

The same problem confronts us, therefore: the rendering which Tertullian gives, here mendicus, is not witnessed to elsewhere, and is limited in Tertullian's work to the $a d u$. Marc. ${ }^{4}$ Nonetheless, the impression is very strong that Tertullian accepts Latin terminology which he feels must be justified for his non-Marcionite readers. It is not clear why he would otherwise have introduced mendicus into his text here, and only here. We cannot be certain of this. Again, taking all the Marcion texts together, it may appear that the only hypothesis which will explain the constant glosses and comments upon the language in them by Tertullian is that which supposes a Latin text to have been known to him, which differs from the biblical language which was traditional in the orthodox North African church.

1 Ibid., p. 20, citing Irenaeus latinus, Cyprian and $e$ for Luc. 14.13; $e$ for Luc. 14.21; b, $m$, vulg. for Luc. 16.22 .

2 For Matth., all mss. witnesses have pauperes (5.3); Luke. as noted in the text above, finds pauperes also for 6.20 , with the exception of $e$, with egenus. While Tertullian is notoriously variable, he seems to use egenus largely of the "economically poor": thus,

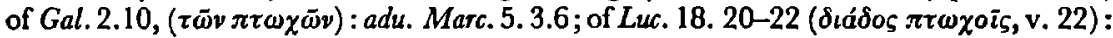
adu. Marc. 4. 36.7, introduced by egenzus in 4. 36.5; de idol. 12.2 seems to cite Matth. 5.3 as '..felices egenos...', but is, perhaps, influenced by Luc. 18.22, which follows: '.. omnia diuidenda..et egentibus diuidenda..'; finally, Luc. 18.22 in de monog. 14.7: egenos. In ad uxor. 2. 8.4, Tertullian appears to be playing on two meanings of pauper.

s PG 56, col. 680 .

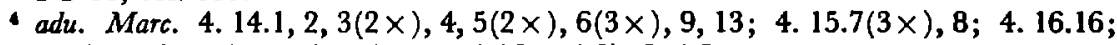

4. 31.1; and see '..mendica elementa..' (Gal. 4.9), 5. 4.5. 


\section{6. adu. Marc. 4. 40.2 (Matth. 27.9 (Zach. 11. 12-13))}

Scriptum est enim: pro eo quod uenumdederunt iustum. Nam et quantitatem et exitum pretii postea Iuda paenitente reuocati et in emptione dati agri figuli, sicut in euangelio Mathei continentur, Hieremias praecait: et acceperunt triginta argentea pretium adpretiati - uel honorati - et dederunt ea in agrum figuli.

The argument of Tertullian is, again, the same. He is able to show that the Christ of Marcion is not without prediction in the Old Testament. But here, Tertullian appeals to Matthew, and through him, to the Old Testament. The text is used in Matthew also to show that everything in the life of Christ is foreshadowed in the Old Testament; and here again, Tertullian's polemic with Marcion resembles an antiJewish polemic.

Tertullian cites the text, and glosses adpretiati with honorati. Now this tells us nothing directly of the language of Marcion's text, for the text is not in Luke. The text is a classic one in the discussion of Latin biblical translations and Tertullian, even apart from the special problematic of the adu. Marc. ${ }^{1}$ Quispel, obliquely accepting adpretiatus as traditional, and therefore from an existing translation (oral or written), explains it as a double translation by Tertullian; but it is not simply a variatio by Tertullian. ${ }^{2}$ It is the why of the gloss that interests us, and which remains, in this explanation, unclear.

adpretiatus, adpretiare occurs only in Christian authors. ${ }^{3}$ The mss. of the Vetus Latina offer adpretiatus for Matth. 27.9, $a$ alone excepted, which gives aestimati, aestimauerunt. ${ }^{4}$ Tertullian cites Matth. 27.9 again, in the same language: '..triginta argenteis adpretiatus a proditore..'5, and seems to play upon the word earlier in the de resurr.: '..cuius passiones sibi adpretiat'. Why does Tertullian gloss the word here in the adu. Marc. with honorati? Taken in the light of his other glosses, Tertullian seems to feel the strangeness of the word, and he glosses it with a close translation of the Greek verb $\tau \iota \mu \tilde{\alpha} \nu .^{7}$ It is, therefore the same process which we have seen, both in the adu. Marc. and elsewhere; a word whose

1 Capelle, Stummer, Aalders, et al. accept the text as probative; others - Zahn, DE LABRIOLLE, - do not.

2 G. Quispel, De Bronnen, p. 134. Quispez does not explain the glossing honorati as a variatio by Tertullian; but does appeal to variatio to explain differences in Tertullian's word choices elsewhere: p. 107, 120.

ThLL II, 308, s.v.

- A. Jülicher, Matthäus-Evangelium, p. 202, ad loc.

- de resurr. 20.5. B de resurr. 9.1.

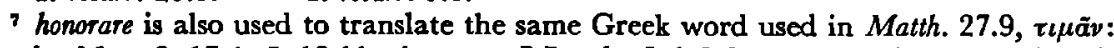
adu. Marc. 2. 17.4; 5. 18.11; de monog. 7.7; adu. Iud. 2.3, etc.; but the comparison is not helpful. 
strangeness, whose otherness, or whose special meaning is not immediately clear is explained with a glossing comment.

The text tells us nothing of the language of Marcion's text; but, taken with its allusive pendant in the de resurr. (as it often is not), it shows us that Tertullian is in contact with a word which is a constant in the Vetus Latina tradition, and which still survives in the Vulgate. To the degree that Marcion stands outside this language and tradition, the word needs explanation. It is also worth noting that this text does not establish the existence of an entire translation of Matthew. It is an isolated text, much quoted in polemic, perhaps ${ }^{\mathbf{1}}$; extrapolating from such texts to the existence of Latin translations of the entire Bible, of even of books of the Bible, goes beyond the evidence.

\section{7. adu. Marc. 5. 4.8 (Gal. 4. 23-24)}

Si enim Abraham duos filios habuit, unum ex ancilla et alium ex libera, sed qui ex ancilla carnaliter natus est, qui uero ex libera per repromissionem, - quae sunt allegorica (id est aliud portendentia); haec sunt enim duo testamenta (siue "duae ostensiones", sicut inuenimus interpretatum). Tertullian is now commenting upon the Apostolikon of Marcion, an edited version of the Epistles of Paul. Here Tertullian quotes the text of the Marcion New Testament much more than was the case for Marcion-Luke; but whether he is quoting from an existing Latin translation, or of the edited Greek, is disputed.

It is curious that Marcion should have left this text in his edition of Paul. It is the great point of departure for the allegorical method of interpretation in the church. That there should be any foreshadowing of the totally new God in the earlier testament; that the very word testament be used, or even ostensio, is odd. But we are sure that Marcion did have the text. Earlier, Tertullian was able to point out that even Marcion admitted some texts to be open only to an allegorical interpretation:2

..cum etiam haereticorum apostolus ipsam legem indulgentem bobus terentibus os liberum non de bobus, sed de nobis interpretetur, et petram, potui subministrando comitem, Christum adleget fuisse, docens proinde et Galatas duo argumenta fliorum Abrahae allegorice cucurrisse....

This independent and explicit confirmation that Gal. 4. 23-24 was in the text of Marcion-Paul is valuable. This text just cited is allusive, 1 The use of the text in Matthew is typical of his attention to the fulfillment of Old Testament prophecy. It does not occur in the Testimonies as we have them, however. See Rendel Harris (with assistance of Vacher Burch), Testimonies, Cambridge, 1916, 1920.

1 adu. Marc. 3. 5.4. 
and it is the only other text where a comparison with our citation from the fifth book is possible. Here we find allegorice; in the fifth book, allegorica, glossed with id est aliud portendentia. The second gloss is quite different: duae ostensiones is not a gloss of testamenta, as it is an indication that Marcion either read a different word in the Greek, or had a different translation in the Latin.

The text from the fifth book is one of the most difficult texts in the entire discussion of Tertullian and a Latin translation in general, and of the language in which Tertullian read his Marcion.

Zahn would change the reading, substituting sponsiones for ostensiones. ${ }^{1}$ But this does not change the problem. Von Harnack's reasoning is quite different: ${ }^{2}$

Tertullian fand (eine andere Auffassung ist nocht moglich) in dem Marcionitischen Codex, dem er folgte, "ostensiones", erinnerte sich aber, dass der ihm selbst gelaufige Text "testamenta" ( haft durch das Wort zu ersetzen, welches im Codex stand. Dass er "ostensiones" fur

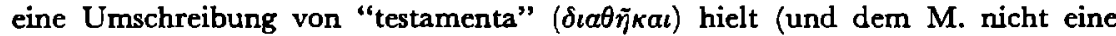
Textfalschung vorwarf) war freilich eine grossmutige und unhaltbare Annahme....... Wie aber auch das Wort griechisch gelautet haben mag - dem Tert. lag in dem Marcionitischen Apostolikon hier "ostensio" vor; es war also lateinisch.

Stummer sees the text as an indication that Tertullian knew a written Latin translation, without, however, attending to the special problematic of the adu. Marc. ${ }^{3}$ Quispel finds it a difficult text; his explanation is overly subtle. ${ }^{4}$ The Vetus Latina tradition is not helpful here. Some mss. have per allegoriam; $d$ has quae sunt significantia; $e$, based on $d$, has per significantia. Augustine commenting, explains: '..quae sunt aliud ex alio significantia...'5; Hilary has the very Greek allegorumena: '..parabolicam, ...siue, ut apostolus ait, allegorumena..' We do not find allegorica; nor, unsurprisingly, do we find ostensiones.

The gloss upon allegorica is clear enough. Tertullian wishes to be certain that the term is adequately understood. He insisted on this aspect of the scriptures earlier, in the third book $^{7}$; he continues to use portendentia and portendo from the de bapt. (8.2) to the de pud. (7.13), and in most of these usages, the word is related to the scriptures and the explanation of them. It occurs in the adu. Marc. far more frequently than elsewhere.

1 Theodor Zahn, Geschichte des neutestamentlichen Kanons, I, P; 52.

a. von Harnack, Matcion ${ }^{2}$, p. $52 *-53 *$.

- F. StUmmer, Einführung in die lateinische Bibel, p. 13.

- G. Quispel, De Bronnen, p. $136 . \quad$ s de trin. 15.15 (PL 42 col. 1068).

- Tract. super psalmos, Ps. 146, 9 (A. Zingerle, CSEL 22, p. 850, 1. 25); cf. also Ps. 118,3 (ibid. p. $507,1.24$ ); 134, 1 (p. 694, 1.3); 147, 5 (p. 857, 1.6).

7 adu. Marc. 3. 5.4 ff. 
testamenta - a word which we have already $\operatorname{seen}^{1}$ - is used to gloss ostensiones. Testamentum is in usu, and was almost certainly not a Marcionite term. The full value of this gloss depends on what one makes of the words: '..sicut inuenimus interpretatum....'. If interpretari does not always mean 'translate' in Tertullian, but depends upon the context, as Quispel rightly says, ${ }^{2}$ the most natural reading here would in fact seem to favor 'translate' as the meaning. Had Tertullian been referring to a change in the Greek text which Marcion certainly made, he might have used other language, as he does elsewhere. ${ }^{3}$

This text, like others we have seen, is often discussed in isolation. Put in the context of the glossing technique of Tertullian, however, we may see Tertullian explaining two terminologies to each other. allegorica - perhaps a word from Marcion latinus, perhaps Tertullian's rendering from the Greek - is explained to make certain that its full meaning is appreciated; ostensiones is explained, on the other hand, as a peculiar word, representing another reading by the Marcionites. Here again, therefore, the double movement of this clarification of language appears: orthodox language is explained for the opponent (for, although they used it, the Marcionites clearly would not see the fullness of meaning which is so important for Tertullian in the adu. Marc.), and Marcionite language is explained for the orthodox reader. It would seem that Tertullian, in contact with another terminology, is therefore in contact with a Latin version of the Marcionite New Testament. But we are dealing in probabilities. What is certain is that Tertullian takes extraordinary pains to assure clarity of language.

\section{8. adu. Marc. 5. 8.5 (Ps. 67.19; cf. Eph. 4.8)}

Accipe nunc, quomodo et a Christo in caelum recepto charismata obuentura pronuntiarit: ascendit in sublimitatem, id est in caelum; captiuam duxit captiuitatem, id est mortem uel humanam seruitutem; data dedit filiis hominum, id est donatiua, quae charismata dicimus. Eleganter "filiis hominum" ait, non passim "hominibus", nos ostendens flios hominum, id est uere hominum, apostolorum.

This very interesting text gives us a perfect cluster of glosses, most of which are exegetical: Tertullian will explain precisely what this text implies. But one of them, at least, is a gloss upon the word data, which Tertullian brings into harmony with usage, charismata.

1 See supra, p. $44 \mathrm{ff}$.

2 G. QUISPEL, De Bronnen, p. 137. For some evident examples where interpretari has hermeneutical force: ad uxor. 2.2.2; adu. Marc. 5. 7.1; de anim. 29.4; de castit. 5.3; and many others.

S., for example, de monog. 11.11; de anim. 11.2. 
The context of the argument in Tertullian is important for an understanding of this text. He has arrived at the locus 1 Cor. 12.1 in his commentary on Marcion-Paul, and begins: 'Nunc de spiritalibus...' (5. 8.4). He follows the usual pattern of his argument; intending to show that the spiritalia and their giver were promised in the Old Testament, by the creating God, Tertullian cites $I s .11 .2-3$ to show that it is Christ to whom the gifts of the Spirit were promised; he then says: 'See now how the Scripture (or the Spirit) pronounces that the charismata will come from Christ, once He has been received into heaven...' and the ascendit text follows.

The context of the argument is important. We are, again, in the atmosphere of a testimonia proof text. As Quispel has very well seen, the text is not cited from Eph. 4.8, but from an Old Testament source, as such. ${ }^{1}$ While von Harnack does not take this section up in his reconstruction of Ephesians (or Laodicenses) according to the Marcionite reading of it, he does appear to attribute it to Eph. 4.8 when discussing the text as an indication that Tertullian was reading his Marcion-Paul in Latin. ${ }^{2}$ The force of von Harnack's argument does not depend on the text coming from Marcion's Ephesians; but it is well to make this clear, since the language and its gloss will not tell us anything directly of the language of the Apostolikon of Marcion.

Had Tertullian not insisted upon the expression, filiis hominum, we might have thought this an error in citing due to memory. The Eph.4.8 citation of Ps. 67.19 does not so read, in text or in the apparatus. The LXX of Ps. 67.19 also does not so read. Quispel suggests Justin, the Dialogue with Trypho, as the source of the citation. ${ }^{3}$ The Justin use of the citation is very much in the direction of Tertullian's argument. Quispel supposes that Tertullian is translating from Justin, and, under the influence of the traditional Latin translation of the Psalm, uses data, which he then explains, with donatiua, charismata.

1 G. Quispel, De Bronnen, p. 130-131.

2 A. von Harnack, Marcion, p. 119*; p. 53*.

${ }^{3}$ G. Qutspel, De Bronnen, p. 131, reference to Dialogue, 87, Otto edition, p. 318. The text occurs again in ch. 39, this time without filiis hominum, and the argument of Justin resembles that of Tertullian even more here.

4 'Ofschoon Tertullianus hier dus uit het Grieksch vertaalt, heeft hij zich gehouden aan de taal van den Latijnschen Bijbel, die steeds "datum", niet "donum" gebruikt als vertaling van $\delta \delta \mu \alpha$, ..terwijl "donativum" de kern is voor het "charisma divinum militibus Christi promissum." "Datum" en "donativum" zijn dus volstrekt geen synoniemen, zoals v. Harnack tracht te betogen. Het eene woord is een exegese van het andere.': G. Quispel, De Bronnen, p. 131.

That donatiuum was a well-known word appears from the uses of it in de resurr. 47.8, de coron. 1.3. See A. von HARNAck, Geschichte der altchristlichen Literatur bis Eusebius, II 2, p. $299-300$. 
There are no less than five glosses in the text adu. Marc. 5. 8.5. Most of them are exegetical; one is a comment on biblical style, with the characteristic eleganter. There is, however, one gloss that has to do with language; that which would equate data to donatiua-charismata. Now data, while hardly dominant, is represented in the Vetus Latina tradition of Ps. 67.19, and Eph. 4.8. ${ }^{1}$ Tertullian feels that the word is not quite clear enough for his argument, and through his gloss he arrives at a word which is understood by both Marcionites and orthodox.

If the text tells us nothing directly of the language in which Tertullian read his Marcion-Paul, it does show us that Tertullian is in contact with a traditional element of old Latin biblical translations. His gloss upon data is not simply because he feels the otherness of the word, but because it must be equated with language which the Marcionites know and understand. It is more difficult to prove that Tertullian is quoting from a Latin translation, and not, as Quispel suggests, translating himself, under the influence of a translation. It is worth insisting again upon the partial nature of such a translation, or what we know of it; we have here to do with a proof text. This text tells us far more of Tertullian's attention to clarity, and his awareness that biblical language was other, than it tells us of the existence of a Latin translation of the scriptures; it says nothing of the language in which Tertullian read his Marcion.

\section{9. adu. Marc. 5 10.16 (1 Cor. 15.55)}

Si autem tunc fiet uerbum quod scriptum est apud creatorem: ubi est, mors, 〈uictoria, ubi〉 contentio tua? Vbi est, mors, aculeus tuus?

Any discussion of his text must be preceded by a discussion of what text should be read here. Kroymann brackets uictoria $u b i$, and reads $u b i$ as preferable to Beatus Rhenanus' editio princeps, which used the Hirsaugensis, now lost. If we read the text, however, with Beatus Rhenanus, we find: '..ubi est, mors, uictoria, uel contentio tua?' There is much to be said for this. Kroymann is influenced by the citation in de resurr. 47.13: '..ubi est mors, contentio tua?'; and in de resurr. 54.5: 'Vbi est, mors, contentio tua?', where contentio in the following context makes the reading perfectly certain; de resurr. 51.6 reads potentia tua, with Pamelius reading contertio here. The two earlier examples are enough to show that Ter-

1 The mss. and the Vulg. usually have dona; Ambrose, de spiritu sancto, PL 16, col. 720, '..dedii dala...' See: Hermann Josef Frede, Epistula ad Ephesios (Vetus Latina, 24/1), Freiburg im Br., 1962-64, ad loc., p. 155, noting the reading data from Ambrose, ms. 86, and some Vulg. mss. 
tullian knows the reading contentio here in 1 Cor. 15.55 . But this is no reason to suppose that uictoria uel should be rejected. While von Hatnack agrees with Kroymann, his reason for rejecting uel, at least, is weak in the extreme: 'Ubrigens hätte Tert. schwerlich eine AlternativUbersetzung bloss durch "uel" eingefürt, sondern sich deutlicher ausgedrückt.' ${ }^{1}$ Quispel would read uictoria uel contentio, rejects von Harnack's objection on the strength of the example of the Matth. 27.9 glossing $u e l$, and sees here two translations by Tertullian, which reflect

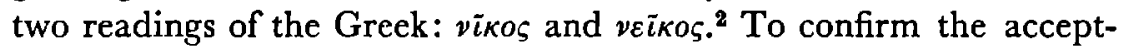
ance of uel we can add the numerous glosses which have already been seen. This is very much the style of Tertullian. If one reads the text in this way, we have a typical gloss: uictoria is explained by what Tertullian feels is the better known translation and reading: contentio. ${ }^{3}$ Quispels opts for this solution: we have here a double translation from the Greek, by Tertullian: uictoria and cortentio. ${ }^{4}$ If one supposes, however, that Tertullian read uictoria in a Latin Marcion translation, which would depend on vicos, and that he then glosses this with the better known contentio, depending on veiкos, the text is clear, consonant with the glossing technique of Tertullian, and a good argument that Tertullian did in fact read his Marcion-Paul in Latin.

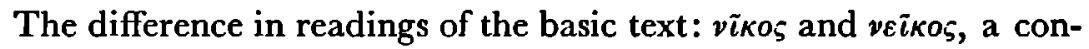
fusion which could easily have arisen from the sound of the two words as read aloud, is massively testified to in the tradition of the Vetus Latina. Quispel cites Cyprian5, and Hilary, who combines the two: '..cum absorbeatur mors a uita in contentione uictoriae....' Jerome has both uictoria and contentio ${ }^{7}$, adding to the dossier of information noted by Quispel; as does Augustine also. ${ }^{8}$

Adopting the reading uictoria uel contentio, then, we find a typical gloss of Tertullian, by which less familiar language is explained by a more familiar term. This strongly suggests that Tertullian read uictoria, and that he therefore read Marcion-Paul in Latin; and, once again, we find Tertullian to be in the tradition of his successors, testifying to differing readings and/or translations. ${ }^{\theta}$

1 A. von Harnack, Marcion ${ }^{2}$, note 1, p. 55*.

2 G. Quispel, De Bronnen, note 1, p. $134 . \quad$ Ibid., p. 133.

5 Ibid., note 2 and 3. Cyprian, test. 3. 58 (G. Hartel, CSEL 3,1 p. 159, 1. 16-17).

- Hilary, Tract. super Psalmos, Ps. 59, 14 (A. Zingerle, CSEL 22, p. 203, 1.1, see also p. $796,1.18$.

For contentio: Jerome, Comment. in Os. 13.14 (PL 25, col. 938); for uictoria: In Psalmos hom., Ps. 73 (G. Morin, CC LXXVIII, p. 238 1.109).

- Augustine, however, favors contentio much more than tictoria.

- In a private letter of June, 1967, Dr. Claudio Moreschini expressed tentative agreement with the reading defended above. 


\section{0. adu. Marc. 5. 17.1 (Eph. 1.9-10)}

Cui ergo competet secundum boni existimationem, quam proposuerit in sacramento uoluntatis suae, in dispensationem adimpletionis temporum - ut ita dixerim, sicut uerbum illud in Graeco sonat - recapitulare - id est ad initium redigere uel ab initio recensere - omnia in Christum, quae in caelis et quae in terris, nisi cuius erunt omnia ab initio, etiam ipsum initium, a quo et tempora et temporum adimpletio et adimpletionis dispensatio, ob quam omnia ad initium recensentur in Christo?

The center of interest here is the word recapitulare. Is Tertullian justify-

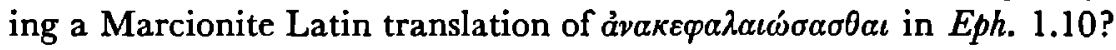
Or is he himself the translator? von Harnack reasons: it is only at first appearance that Tertullian seems to be translating from the Greek. $\mathrm{He}$ is only shrinking somewhat before the quite new and incomprehensible word "recapitulare", excuses it as a Graecism, and explains its meaning. Had he not found recapitulare in his text, he would have used "ad initium redigere" immediately or some similar expression." Von Soden agrees with this view. ${ }^{2}$ Quispel reads the text as an indication that Tertullian is translating from the Greek; that he wishes to underline the meaning of the Greek, to bring out his own argument. ${ }^{3}$

Tertullian uses recapitulare again in adu. Iud. in its rhetorical meaning, to sum up. ${ }^{4}$ His glossing explanation, '..id est ad initium redigere uel ab initio recensere..' appeals to a word which Tertullian favors, and which is characteristic of him: recensere. His hesitation in rendering the locus Eph. 1. 9-10 appears later, in the de monog.:

'..apostolus scribens ad Ephesios Deum proposuisse in semetipso ad dispensationem adimpletionis temporum ad caput, id est ad initium reciprocare uniuersa in Christo....'.5

'..Si enim secundas nuptias permittit, quae ab initio non fuerunt, quomodo affirmat omnia ad initium recolligi in Christo?

Recensere, however, is his preferred word, and it appears four times in the adu. Marc. discussion of the text from Ephesians. ${ }^{7}$ One can only hesitate here. The ut ita dixerim of Tertullian seems to apologise for the word recapitulare, as he seems to apologise for his use of edictum to describe the beatitudes. ${ }^{8}$ It does not seem possible to see anything more here than Tertullian's care for precision of language.

We find recapitulare used by Irenaeus latinus to translate Eph. 1.10,

1 A. von Harnack, Morcion", note 1, p. 53*.

2 H. von Soden, Der lateinische Paulustext, p. 238.

\& G. Quispel, De Bronnen, p. 108-109.

adu. Iud. 8.8. 5 de monog. 5.2. "de monog. 11.4.

7 adu. Marc. 5. 17.2-3.

8 adu. Marc. 4. 14.1; see supra, p. $50 \mathrm{ff}$. 


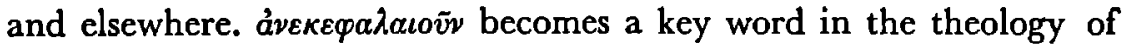
Irenaeus, of course. ${ }^{1} \mathrm{~A}$ text of Jerome is well worth quoting, where he criticises the translation which he knew: ${ }^{2}$

..pro recapitulare in Latinis codicibus scriptum est instaurare (al. restaurare). Et miror cur ipso uerbo Graeco non usi sunt translatores, cum istiusmodi licentia, dialectica et philosophica sicut in Graeco habentur, assumptae sint.

From this we may conclude that recapitulare never entered the mainstream of the tradition of the Vetus Latina, despite its use by Irenaeus latinus, just as mendicus, as translation of Luc. 6.20 never entered that tradition. ${ }^{3}$ But a conclusion as to the language in which Tertullian read his Marcion-Paul does not seem possible, from this text.

Other texts from the Apostolikon of Marcion have often been cited as indications that Tertullian read it in Latin: Gal. $3.26^{4} ; 1$ Cor. $6.20^{5}$; Eph. $1.12^{6} ;$ Col. $1.17^{7}$, for example. These texts do not offer us glosses,

1 See the Sanday, Turner, Souter edition, Novum Testamentum S. Irenaei Episcopi Lugdunensis (Old Latin biblical Texts 7), Oxford, 1923, p. 161-I62; Hermann Josef Frede, Epistula ad Ephesios (Vetus Latina 24/1), Freiburg im Br.,1962-64, ad loc., p. 21-22.

2 Comment. in Eph. I, 1 (PL 26 cols. 453-454).

- See supra, p. $50 \mathrm{ff}$.

- adu. Marc. 5. 3.11. Tertullian's citation here reads: '..omnes enim filii estis fidei..', and he goes to insist on this reading. von HarNack concludes that this is due, not to a change in the Greek text, by Marcion, but to a fault in the Latin tradition; the same fault appearing in Hilary: Marcion $^{2}$, p. $51^{*}-52^{*}$, and note 1, p. 52*. Tertullian cites the text elsewhere more exactly: '..si homines per fidem filios Dei factos...'; adu. Prax. 13.4.

s adu. Marc. 5. 7.5. Tertullian cites the text indirectly: 'Iam quomodo honorabimus, quomodo tollemus deum in corpore perituro?'. This apparently depended on a false reading of the Greek, ăocte in place of ăoa ye; (see apparatus ad loc., Nestle-Aland). Our Vulgate still testifies to this error: 'Glorificate, et portate Deum in corpore vestro.'. Cf. A. von Harnack, Marcion', p. 54*. Tertullian witnesses to the same reading in de resurr. $10.5 ; 16.14$.

- adu. Marc. 5. 17.3. Tertullian's citation: 'Nam et sequentia quam renuntiant Christum, cum dicit: ut simus in laudem gloriae (eius) nos, qui praesperauimus in Christum? Qui enim praesperasse potuerunt, id est ante sperasse in deum quam uenisset, nisi Iudaei, quibus Christus praenuntiabatur ab initio? 4. Qui ergo praenuntiabatur, ille et praesperabatur.' praesperare, which occurs once again in section 4 of this same passage, is a word which is used only here by Tertullian, and upon which he insists; he explains the word by '..ante sperate..quam..'. On this, see A. von HARNACK, op. cit., 54*; G. QuTSPEL, De Bronnen, p. 132.

? adu. Marc. 5. 19.4. Tertullian: '..et ipse est ante omnes. Quomodo enim ante omnes, si non ante omnia?'. voN HaRvack reasons: had Tertullian wished to use the expression ante omnia, he could have translated the Greek directly. Since he does not do so, but arrives at ante omnia by arguing from ante omnes, it is evident that he is not translating from the Greek, but found ante omnes in his Marcion text: op. cit., p. 54*. For another view, see G. Quispex, De Bronnen, p. 132-133. Tertullian alludes to this text in adu. Hermog. 4.2: '..nisi quod ante omnia..'. Our Vulgate has ante omnes, as do the mss. Augustine reads ante omnia: de Genes. ad litt. 8.26 (J. Zycha, CSEL 28, 1, p. 265, 1. 21). ante omnes: Coll. cum Maximino Arr. episcopo, PL 42 col. 719; Jerome, ante omnia: ep. 98.12 (I. Hilberg, CSEL 55, p. 195, 1. 30), etc. 
however, but rather seem to betray a Latinity, or a basic text which would be explained only on the assumption that Tertullian cited them from an existing Latin translation of Marcion-Paul.

\section{Conclusion}

The intent of this chapter has been to take those classic texts which have been cited as indications that Tertullian knew a Latin translation of the scriptures, and to discover from them Tertullian's attitude towards scriptural language, and to take a fresh look at them from the vantage point of Tertullian's glosses.

We first note a certain duality of language. In the same scriptural passage, we find amartia/delictum, congressus/confabulatio, stuprum/fornicatio, politeuma (politia)/municipatus, where the second word in these pairings is a traditional element, and where the first is not.

More interesting are the comments which Tertullian makes on language which is clearly not of his own devising, which he criticises, sometimes for theological reasons (spiritus, sermo, dormierit), and which continues to be witnessed to in the tradition of the Vetus Latina.

Tertullian respects usage, and conforms himself to it. If he is slightly critical of sermo, he uses it constantly, nonetheless, in references to the Johannine prologue. He would prefer to speak in terms of adulterium and stuprum, and does so, with the notable exception of the de pudic., where, typically, he adjusts himself to the language of his adversary. His use of uerbum instead of sermo in the de carn. is doubtless to be explained in this way, and not as a stage in the development of Tertullian.

$\mathrm{He}$ is conscious of the otherness of scriptural language and style; and he explains words and expressions with a covering gloss, so that they will be perfectly clear to his readers. Other words, based on Scripture, and which have a special value for Christians, are also explained. This differentiation is not only along the dividing line of Christian and nonChristian; it is also functional between differences within the church, as with ecstasis, a word which is not merely a transliteration of the Greek of Gen. 2.21, but a word laden with a special value for the Montanist Tertullian. It is therefore glossed, to make it clear. Thus far, there is no doubt but that Tertullian is in contact with Latin renderings of some parts of the scriptures. While the most probable view of these is that they were not merely oral, but written, the texts upon which Tertullian reflects are most often key texts, isolated sections of the Scripture (like the Johannine prologue), or texts frequently appealed to, like 1 Cor. 7.39. This is quite commonly accepted, of course. What 
is interesting to note is the constant attention to language, the awareness of its theological importance, and that this language and style of the Bible is other: therefore the glosses.

This constant reflection on language and on existing renderings makes for continuity between Tertullian and his successors. Just as Jerome and Augustine and others witness to variety of renderings of the same locus, and reflect upon the translations which they knew, Tertullian is already engaged in the same process. Sometimes with greater acumen than his successors showed, with independence which permits him to examine the Greek and translate it for himself, and always with an eye for clarity and precision of language.

Using the vantage point of this linguistic sensitiveness of Tertullian, and his technique of glossing, a fresh view may be taken of the loci classici from the adu. Marc. It is precisely here, in the fourth and fifth books against Marcion, that Tertullian is most the glosser of language. Taking all these texts together, and in relation to the constant covering explanations of words, we seem to see a double movement: traditional language, used in proof texts from the Old Testament, but also from the New, is explained to the Marcionites: and Marcionite language is explained to the orthodox readers of Tertullian. Both sorts of language are being glossed. Therefore, some of these texts tell us nothing directly of the language in which Tertullian was reading his Marcionite New Testament. Tertullian is arguing in the manner of the testimonies: proving the continuity between the Christ of the New Testament, even in Marcion's version, and the Old Testament, where he was prefigured and promised. But many of the glosses are of Marcionite language also. The incidence of glosses with this double movement seems inexplicable, unless Tertullian was in contact with two sets of terminologies; and this in turn indicates that Tertullian read his Marcion-Luke and -Paul in Latin. Here again he is independent, and consults the Greek. But he is also reflecting language which he must explain. The studies of von Soden, for Marcion-Paul, and Higgins, for Marcion-Luke, which indicated from lexical evidence that the scriptural language of Tertullian in these places differs from his language elsewhere, and that therefore, he knew Marcion's New Testament in Latin, seem to be supported by this glossing activity of Tertullian. 


\section{IMAGERY}

\section{INTRODUCTION}

While Heinrich Hoppe ${ }^{1}$ has dedicated two chapters of his study of Tertullian to Metapher and Gleichnisse, there remains much to say about Tertullian's imaginative language. This chapter, in its remarks on Tertullian's imagery, would do three things. The first aim is to give some idea of the unity and the function of this imagery. We know that rigare in apol. 47.2 is used metaphorically; but it is interesting to see that this takes its place in a whole complex of water imagery, where water is associated with Scripture and the Spirit, and which, needless to say, owes its inspiration to the Bible. We know that vegetation imagery is quantitatively the most important single axis, perhaps, in Tertullian; it can also be noted that given functions are served by this imagery in a regular way. It is the first intent of this chapter, therefore, to indicate some of the more important directions in the unity and the functionality of Tertullian's imagery.

Tertullian is tributary to the Bible, and also to the immense learning of the 'classical' world which is manifest on his every page; literature, science, law, rhetoric, philosophy. It is therefore interesting to see that all of the great themes of imagery in Tertullian show a remarkable crossing in sources, between the biblical and the Latin sources anterior to Tertullian. That he was also perfectly at home in Greek literature needs no reminder here; but only Latin literary sources, and the Bible will be appealed to here. What is more, it must be remembered that Tertullian is not the first to witness to this meeting of cultures, and he owes much to his predecessors. This meeting of sources has important results for the value of his imagery. Interestingly, Tertullian sometimes shows himself to be aware of the otherness of biblical imagery, just as, in the preceding chapter, his glosses showed his sensitivity to the otherness of biblical language.

Finally, we will have occasion to note some word plays which are

1 Heinrich Hoppe, Syntax und Stil des Tertullian, Leipzig, 1903; ch. 15, Metapher, p. 172-193; ch. 16, Gleichnisse, p. 193-220. 
possible precisely because they occur in the field of imagery; and also, to note how certain words are wholly, or almost wholly, caught up in a biblical field of association. Imagery is a broad category. Modern critics of literature have paid a great deal of attention to imagery, a heading which includes simile, metaphor, symbol, myth. ${ }^{1}$ Caroline Spurgeon, one of many investigators of Shakespeare's imagery, made a classic analysis of the imaginative language of Shakespeare, which, for all the criticisms which have been made of it, is a remarkable cataloguing of the complicated paths which imagery can take in an author. She uses a very broad basis as her definition:

I use the term 'image' here as the only available word to cover every kind of simile, as well as every kind of what is really compressed simile - metaphor. I suggest that we divest our minds of the hint the term carries with it of visual image only, and think of it, for the present purpose, as connoting any and every imaginative picture or other experience, drawn in every kind of way, which may have come to the poet, not only through any of his senses, but through his mind and emotions as well, and which he uses, in the form of simile and metaphor in their widest sense, for purposes of analogy.

Among other criticisms which have been made of Miss Spurgeon's book, the one which is most telling reproaches her for attempting to discern the poet's own attitude of mind, and his experience of the world, from the imagery of a particular play. ${ }^{3}$ Other critics would use imagery studies simply to show the function of imagery in a play, poem, or other composition. These studies have not been limited to modern literature. A recent bibliography of imagery studies in Latin and Greek literatures and in the Bible, ${ }^{4}$ shows how numerous are the studies which have been made of various authors, as well as synthetic studies of the phenomenon of imagery itself. A modern critic like Philip Wheelwright has examined the Oresteia from the point of view of this contemporary interest in imagery; one understands the plays better in view of the function of imagery, for example, of nets, snares, hunting. ${ }^{5}$

There have been, naturally, many theoretical studies of imagery. But, just as Hoppe admitted the difficulty of a sharp distinction between metaphor and simile, ${ }^{\circ}$ more recent critics have had difficulties

1 Rent Wellex and Austin Warren, Theory of Literature, New York, 1948; ch. 15: Image, Metaphor, Symbol, Myth, p. 190-219.

2 Garoline Spurgeon, Shakespeare's Imagety and What it Tells Us, London and New York, 1935; Paperback edition, 1965, p. 5.

- René Wellek and Austin Warren, Theory of Literatute, p. 214.

- Bibliographie zur antiken Bildersprache, unter Leitung von VIKTOR PöschL, bearbeitet von Helga Gärtner und Waltraut Heyke, Heidelberg, 1964.

- Philip Wheelwricht, The Burning Fountain, Bloomington, 1954; ch. 12, Thematic

Patterns in the Oresteia, p. 232-267.

- Symtax und Stil des Tertullian, note 1, p. 193. 
with clear distinctions. ${ }^{1}$ Metaphor is traditionally defined as the identification of one thing with another, the other being usually a sensible object, though it need not be; and simile, a comparison between the two, using like, as. As these comparisons grow more lengthy, one comes to the area of fable, allegory, myth. Symbol has been defined as something' ... which refers to another object but which demands attention also in its own right as a presentation.'2 But, if Tertullian regularly uses water in connection with the Spirit, then even the apparent simple metaphors in rigare, potare, effundere, take on symbolic character.

We will be dealing most often with metaphor and simile; however, symbol is also highly important in Tertullian, and the value of some of his axes of imagery itself approaches the symbolic. He is more often metaphorical in his language than not. He does use uelut, quasi, $u t$, and that typically Latin, hesitating, quodammodo, introducing comparisons. Usually however he is bold, and identifies. He is vivid. He is capable of infusing new life into a cliche, and he almost always can still see the image value of well worn language. $\mathrm{He}$ is extraordinarily logical in his articulation of an image, and only occasionally does he lose control of the central term of comparison. That he is always in good taste is something else again. ${ }^{3}$

Image is a psychological term as well as a category of literary criticism.4 Carl Jung has pointed out the curious parallel between patterns in mythology, and the patterns which emerge in the human unconscious. ${ }^{5}$ Images also interest the language analyst, - Ian Ramsay is an example - the biblical theologian ${ }^{6}$, as well as other specialists. Here the interest is on image as a literary category. Tertullian uses imaginative language - simile, metaphor, symbol - in a relatively consistent way, to express given values and ideas. A study of his imagery need not reveal to us his personal, immediate experience of the world. He is in an extremely complicated tradition which draws upon the 'classical' and the 'biblical' worlds. It must be clear that a sharp division here again is impossible. When Paul, in 1 Tim. 1.19, says that Alexander and Hymenaeus, with others, are shipwrecks in the faith, '..... $\pi \varepsilon \varrho i \tau \eta \nu$

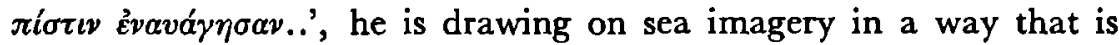

1 Cf. Rene Wellek and Austin Warren, op. cit., p. 191-193, and passim.

Ibid., p. 193.

3 A good example is found in the well-known passage, de cam. 4.5: 'Si reuera de lupa aut sue aut uacca prodire uoluisset et ferae aut pecoris corpore indutus regnum caelorum praedicaret, tha, opinor, censura praescriberet: "Turpe hoc deo..".'

4 WelLeK and WARREN, op. cit., p. 191.

s See Philip Whrelwigut, op. cit., p. 90-92.

- See the essay of MeIR Weiss, Methodologisches über die Behandlung der Metapher, Theologische Zeitschrift 23 (1967), p. 1-25. 
perfectly familiar to classical literature. It is interesting, however, to observe the change in some of these commonplaces in Tertullian. By the fact that many of them now have an added, biblical resonance, they have been deepened, transformed. Here, again, much has been written. ${ }^{1}$ A radical separation of the two traditions is not possible, and no attempt will be made to detail two different psychologies of biblical and classical worlds.

In sequence, the following axes of imagery in Tertullian will be discussed: vegetation; the sea, water and the Spirit; bestiary themes; clothing; medicine; arms and athletics; the plastic view of creation; and, in passing, other, minor themes. The general plan followed is to show, briefly, how given themes had already been employed in Latin literature before Tertullian; for Tertullian, after all, is not merely a corpus uile for philologists and theologians, but is an important Latin author. If his influence is difficult to trace, due to a certain damnatio memoriae, one suspects that it was considerable in the case of Jerome, and also, perhaps, Augustine. After a glance at the literary tradition before Tertullian, the unity, function, and biblical inspiration of these themes of imagery in his works will be shown, and this is the main emphasis of this chapter. Finally, some word plays will be noted, plays made possible by his use of imagery; then too, how some words have a predominantly, or even exclusively biblical referent.

Also of interest are the occasional comments which Tertullian makes on biblical imagery. He is well aware of its special value, and, to a certain degree, of its otherness. As with biblical language, in the first chapter, so also here with biblical imagery; it draws explanations from Tertullian, who, here as always, is intent on clarity.

This chapter, therefore, is a transitional one. The comments on imagery which we will see have an important bearing on the exegesis of Tertullian. For all his limiting of the Scripture, he is open to the deeper meaning which the things, as well as the words of Scripture have (de resurr. 28.1).

With this by way of introduction, then, we come to the first of the themes which interest us.

1 The chief works in this area are the two books of Hugo Rahner, Griechische Mythen in christlicher Deutung, Zuirich, 1945, 1966' ;ymbole der Kirche: die Ekklesiologie der Väter, Salzburg, 1964. See also: Herbert Musurillo, Symbolism and the Christian Imagination, Baltimore, 1962 ; Jean Danit́lou, Les symboles chrétiens primitifs, Paris, 1961; on imagery in Paul, Werner Straub, Die Bildersprache des Apostels Paulus, Tubingen, 1937. In the apostolic Fathers: Heinz PiesIK, Bildersprache der apostolischen Viter, (Dissertation), Bonn, 1961. 


\section{Vegetation}

Tertullian employs imagery of vegetation more than any other single category. He draws upon classical commonplaces, and also upon the Bible, and suggests many different effects through his use of it. One may begin conveniently with the image of the forest.

silua Cicero ${ }^{1}$ uses this image frequently to suggest abundance of material available to the orator; an abundance from which a selection may be made; Quintilian, to describe the undisciplined first draft of a speaker. ${ }^{2}$ The image has a fairly considerable history before Tertullian. ${ }^{3}$ He uses it, however, in a slightly different way. There is, first of all, the sense of an abundance which is good: 'Reuera quio dirigam nescio in tanta frequentia eiusmodi uocum, tamquam in silua uel in prato uel in nemore pomorum..' (adu. Marc. 4. 14.3); of scriptural texts, again: '..quia pauca sunt quae in silua inueniri possunt..' (adu. Prax. 20.3). More often, however, we find the image used with the suggestion of an abundance which is bad. Running through the complex of vegetation imagery in Tertullian is the notion that luxuriance, complication, density are somehow evil. Possibly present in de anim. 2.5; 24.11, this connotation is clear in apol. 4.7: '..totam illam ueterem et squalentem siluam legum nouis principalium rescriptorum et edictorum securibus ruspatis et caeditis..'. It is useful to contrast with this usage a more developed one, where the biblical influence upon the silua image is apparent, as is also the characteristic trait of Tertullian in his use of imagery: a full and logical development. The text is found in de pudic. 16.12:

Si uis omnem notitiam apostoli ebibere, intellege, quanta secure censurae omnem siluam libidinum caedat et eradicet et excaudicet, ne quidquam de recidiuo fruticare permittat, aspice illum a iusta fruge naturae, a matrimonii dico pomo, animas ieiunare cupientem.

As other texts show (de paenit. 4.3; adu. Marc. 1. 29.5; de exhort. cast. 6.3): the axe is no longer the simple one of apol. 4.7, but the biblical axe of Matth. 3.10 (// Luc. 3.9). Here already we touch upon aspects of Tertullian's imagery which interest us: how the classical commonplace is touched with a biblical overtone; and how Tertullian develops his imaginative language in a full, but almost always logical, way. Silua, in Tertullian, is abundance, but most often an evil abundance. He describes the growth of Gnostic ideas in this way: growth, and at the same time, a certain degeneration:

1 See: de orat. 3. 26.103: '..silua rerum.',; 3. 30.118: '..omnis uirtutum et uitionum... silua..'; orator 3, 12: '..omnis enim ubertas et quasi silua dicendi...'.

2 de inst. or. 10. 3.17.

s See, for example, the note of J. H. Waszinx, ad de anim. 2.6, De Anima, p. 11. 
Talia ingenia superfruticant apud illos ex materni seminis redundantia. Atque ita inolescentes doctrinae Valentinianorum in siluas iam exoleuerunt Gnosticorum (adu. Val. 39.2).

Another text which makes clear this connotation of 'evil abundance' in the silua complex is found in ad nat. 2.9.2 (and cf. 1. 12.13): '..humani erroris latitudo, immo silua caedenda, quae undique conceptis superstitionum seminibus uitiisque ueritatem obumbrabit..'

luxuriance It is not clear that luxuriance of vegetation was ever a commonplace in classical imagery. Vergil, in the Georgics, connects luxuriance and infecundity. ${ }^{1}$ Words like pullulare, inolescere, are prominent in Tertullian, and the late inolescere is popular with Christian authors in both a good and a bad connotation. ${ }^{2}$ In all events, this evil abundance is a dominant note in Tertullian's use of vegetation imagery. A good example is his description of the growth of fama (ad nat. 1. 7.5; (l apol. 7.12):

( fama)..exinde in traduces quodammodo linguarum et aurium serpit et modicum originum uitium rumoris obscurat, ut nemo recogitet, ne primum illud os mendacia seminauerit...

If the fecundity which pullulare evokes is neutral in de anim. 19.6, and even favorable in adu. Iud. 2.3, it is, in most cases, evil: '...ista ingenia de semine hypocritarum pullulare consuerunt..' (de paenit. 5.13); '.. his iom tune pullulantibus seminibus haereticis..' (adu. Val. 3.4). An excellent contrast of fruitful and unfruitful growth is found in an opposition in the de pudic. (6.16): '...non lasciuiae frondibus, sed sanctimoniae floribus...'.

Tertullian moves easily into biblically inspired imagery of the same sort. The Matthaean parable of the good and the bad seed fits perfectly into this larger matrix (Matth. 13.24-30). This source is already present in the text just quoted from the $a d u$. Val., 3.4. Tertullian makes much of the biblical image. Marcion and other heretics '..uenena doctrinarum disseminauerunt..', but this is explained by '..illius quoque parabolae patrocinio quae bonum semen frumenti a Domino seminatum in primore constituit, auenarum autem sterilis faeni adulteratum ab inimico diabolo postea superducit.' (de praescr. $30.2 ; 31.1) .{ }^{3}$ Briefly mentioned in de anim. 16.7 , the parable is elaborately developed, with accent on the sterile fecundity, in adu. Prax. 1.6-7:

1 Vergil, georg. 2.48: '..infecunda quidem, sed laeta et fortia surgunt..'; cf. 1. 187-192. But these usages are quite other than the value which Tertullian attaches to luxuriance.

2 ThLL VII, 1, fasc. xi, cols. 1738-39. For the usages of inolescere in Tertullian : ad nat. 2. 12.32; apol. 40.10; de patient. 13.2; de anim. 16.1; de uirg. uel. 10.4, and the text adu. Val. 39.2, quoted above. For pullulare: de paenit. 5. 13(2×); adu. Val. 3.4; and texts quoted above. See also pullulatio, which occurs once, apol. 19.1.

'Cf. Vergil, georg. 1. 154: '..et steriles dominantur auenae.', in a context of sterile fecundity. 
Fruticauerant auenae Praxeanae hic quoque superseminatae, dormientibus multis in simplicitate doctrinae; traductae dehine per quem Deus uoluit, etiam euulsae uidebantur...7...Auenae uero illae ubique tunc semen excusserant, ita aliquamdiu per hypocrisin subdola uiuacitate latitauit et nunc denuo erupit.

Tertullian details the parable in terms of his own imagery of luxuriance.

growth If luxuriance of growth is very generally suggestive of evil in Tertullian, another complex of vegetation imagery connotes a development, a growth that is good, and a unity. This complex uses the words semen and tradux most frequently. Semen is an obvious enough image to suggest origin and source; used in this metaphorical way, it is frequent in Cicero, ${ }^{1}$ for example. Ignoring the biological uses, and the special value which semen has in the Gnostic systems, ${ }^{2}$ one notes occasional suggestions of growth that is evil (as in ad nat. 1. 14.2, of the Jews as '..seminarium..infamiae nostrae..'; adu. Marc. 2. 10.5, '..delictum seminauit..'). Ordinarily, however, the complex suggests good development. The most famous use is found in the Apologeticum: 'Discipuli...sanguinem Christianum seminauerunt.' (Apol. 21.25); 'Etiam plures efficimur, quotiens metimur a uobis: semen est sanguis Christianorum!' (apol. 50.13). The metimur shows that Tertullian still is conscious of the image value of this metaphor. It is doubtful that this phrase is inspired by the Johannine figure of the vine, which, when pruned, yields more fruit. ${ }^{3}$ Tertullian is insisting upon the paradox here.

Semen represents the good origin, whence philosophers derive their ideas, but debase them: 'Etiam fructibus a semine degenerare contigit!' (apol. 19. fragm. Fuld. 6) ${ }^{4}$; philosophers in turn supply the seed for false interpretations of the New Testament (apol. 47.9). It is from apostolic churches that '..traducem fidei et semina doctrinae ceterae exinde ecclesiae mutuatae sunt..' (de praescr. 20.5). We find an elaboration of this imagery in its use to suggest unity and development in scorp. 9.3:

..cum propagine nominis, cum traduce spiritus sancti in nos quoque spectasset etiam persecutionis obeundae disciplina ut in hereditarios discipulos et apostolici seminis frutices.

In these last citations, the word tradux appears. This image, taken from viniculture, uses the vine tendril, passing from pole to pole, to suggest

1 Cicero, Catil. 1. 12.30: '...semen malorum omnium..'; de off. 2. 8.29: ‘..bellorum ciuilium semen..'; Phil. 2. 22.55: '..huius belli..semen.. fuisti..', etc.

In the adu. Val. semen is peculiarly important; it suggests, nonetheless, considerable imagery of vegetation. Some usages of semen in the adu. Val. 3.4; 4.2;4.4; 25. 1-3; 39 , etc.

3 As J. P. Waltzing suggests, in his commentary ad loc. See: Tertullien, Apologétique, Paris, 1931, p. 324-325, quoting Justin, Dial. 110, clearly influenced by John.

+ Cf. Vergil, georg. 1. 197: 'uidi lecta diu et multo speclata labore/degenerare tamen... 
development in an organic way. Tertullian is fond of the metaphor ${ }^{1}$, which should be taken in the larger context of the vegetation complex which he so much favors.

The dynamic and organic aspects of this imagery serve Tertullian to show development and unity. He departs from the biblical '..fructus paenitentiae..' (Matth. 3.8) to expand and explain the figure: '..Ita cessatio delicti radix est ueniae, ut uenia sit paenitentiae fructus..' (de pudic. 10.14). This is useful when Tertullian comes to the relation of the two testaments. Over against the radical separation made by Marcion, Tertullian claims an organic, developing unity: 'Sicut fructus separatur a semine, cum sit fructus ex semine, sic et euangelium separatur a lege, dum provehitur ex lege, aliud ab illa, sed non alienum, diuersum, sed non contrarium.' (adu. Marc. 4. 11.11); 'Ita cuius inuenio praecepta et semina praeceptorum uel augmenta, eius apostolum agnosco.' (adu. Marc. 5. 18.7). Thus the Old Testament is the root of the New (scorp. 2.2); revelation grows and develops, and in the law given Adam were present, in a mysterious way, the laws which grew to fullness in those given by Moses: '..quae postea pullulauenunt data per Moysen..' (adu. Iud. 2.3); '..quae suis temporibus edita germinauerunt.' (adu. Iud. 2.6). The growth of revelation appears to continue even beyond the two testaments, as a highly articulated figure would seem to present the Montanist view of growth, and a greater clarity in that revelation:

Aspice ipsam creaturam paulatim ad fructum promoueri. 6. Granum est primo, et de grano frutex oritur, et de frutice arbuscula enititur; deinde rami et frondes inualescunt et totum arboris nomen expanditur, inde germinis tumor et flos de germine soluitur, et de flore fructus aperitur (de uirg. uel. 1. 5-6).

We may find here vague biblical associations, from Matth. 13.31-32, and especially from Marc. 4. 26-28, 31-32. Tertullian goes on the explain the figure as meaning the development of iustitia through the two testaments to the revelation of the Montanist Paraclete. Here, as usual, Tertullian elaborates his imagery in a logical, though somewhat overfull way.

To explain the unity of the Trinity, Tertullian appeals to wellknown images of light, water, and vegetation. This latter theme, which interests us, permits him to bring out the same values of unity and development: '.. sicut radix fruticem et fons fluuium et sol radium.... Nec dubitauerim Filium dicere et radicis fruticem...Nec frutex tamen a radice nec fluuius

1 Tradux gives a name to Traducianism. See J. H. WAszink, De Anima, p. 175, note ad de anim. 9.6. Some occurrences of the many in Tertullian: ad nat. 1. 4.2; 7.5; 12.11; 16.12; apol. 7.12; 9.17; 21.12; de test. an. 3.2; de praescr. 20.5; 32.3; de patient. 5.10; adu. Marc. 1. 24.1; 4. 1.4; 35.2; adu. Val. 25.3; de anim. 9.6; 36.4; de cam. 9.3; 20.5; de resurr. 7.2 ; scorp. 9.3; etc. 
a fonte nec radius a sole discernitur, sicut nec a Deo sermo.'(adu. Prax. 8.5)1. The light metaphor, used earlier, was itself explained by vegetation imagery: 'Manet integra et indefecta materia matrix, etsi plures inde traduces qualitatis mutueris.' (apol. 21.12). Used in quite another context, the combination of figures again expresses identity: 'Nam et riuulus tenuis ex suo fonte et surculus modicus ex sua fronde qualitatem originis continet.' (de spect. 7.4).

In the tradition of the apologists ${ }^{2}$, and following Paul, Tertullian uses the seed figure to express the resurrection. Here again, the emphasis is on identity, continuity, development; but his inspiration is almost wholly biblical. Departing from a recent event in Carthage, Tertullian says that the bones, hair, and teeth of the long dead '...ut semina retinentur fruticaturi corporis in resurrectione..' (de resurr. 42.8). This complex is developed later in the treatise, and is inspired by 1 Cor. 15. 35-38; the stress in this elaboration is on identity (de resurr. 52), and this same preoccupation with the identity of the risen body with the flesh of now is found in de resurr. 56.5: 'Quale est, ut eadem anima, quae... in hac carne deum didicit et Christum induti et spem salutis seminauit, in alia nescio qua metat fructum?' Behind this we may see 1 Cor. 9.10, as also, perhaps, a hint of Ps. 124.6. This biblically inspired axis of imagery is used in exactly the same line that the classically inspired imagery of seed takes: identity in development.

When Tertullian calls God the '..uniuersitatis conditor, mundi totius gubernator, hominis plasmator, uniuersarum gentium sator..', he indulges his taste for active nouns ending in -or, and draws on both his traditions. Plasmator, as we will see, ${ }^{3}$ is a Christian invention; sator, as imaged epithet of God, is a commonplace from the time of Pacuvius. ${ }^{4}$

varia The whole complex of vegetation imagery is the most important single axis of imagery in Tertullian. He draws on both classical and biblical traditions, and uses it in a varied and ambivalent way. In closing this section, some other uses of the theme can be noted.

The Gospel comparison of the good and the bad tree, and their fruits, rules the discussion of the apparently evil world, and its creator.

1 On these comparisons, see: Joseph Monst, Theologie trinitaire de Tertullien (Théologie, nos. 68, 69, 70 and ?) Paris, 1966, III, p. 761 ; p. 781.

- See E. Evans, Q. Septimii Florentis Tettulliani De resurrectione liber, London, 1960, p. xoxiv-xoxiv, on the apologists and Irenaeus on the resurrection.

3 See infra, p. 114 and note. The text cited is from adu. Iud. 2.1.

4 As early as Pacuvius we find sator: Perib. 16: '..aeternum morum sator..'. Cicero, de nat. deor. 2. 86: '..omnium..renum..seminator et sator..'; Tusc. 2.21 ; ‘..tu. .caelestium sator..'. Vergil, Aen. 1. 254: '..hominum sator atque deorum..'; 11. 425; Statius uses similar expressions extremely frequently: Theb. 1. 178-179: '..tibi, summe deorum terranumque sator..'; $3.218 ; 488 ; 5.22$, etc. 
Marcion ${ }^{1}$ appears to have used the text (Luc. 6. 43-44;// Matth. 7.18), and Tertullian, reflecting, as he often does, the language of his opponent, takes up the phrase repeatedly. ${ }^{2}$ This image is to be seen in the whole context of the discussion of good and evil, and the polemic with dualists. Interesting is a text which shows how Tertullian still appreciates the imaginative value of the formula, and how he elaborates an image in a logical, but rather overdone way:

Agnoscat hinc primum fructum optimum, utique optimae arboris, Marcion. Imperitissimus rusticus quidem malam in bonam inseruit. Sed non ualebit blasphemiae surculus; arescet cum suo artifice et ita se bonae arboris natura testabitur. Aspice ad summam, qualia sermo fructificauerit... (adu. Marc. 2. 4.2).

This development depends on the model of grafting. A curious use of this language is found in de test. an. 5.6: '..uel Iudaeos..., in quorum oleastro insiti sumus..'. Tertullian seems to be drawing upon Rom. 11.17, 24; but he has changed the picture somewhat. For it is now the Jews that are figured in the wild olive. ${ }^{3}$ Another text which departs from the tree culture model displays that special value which sterile fecundity, unfruitful luxuriance have for Tertullian:

Etiam de oliuae nucleo mitis et opimae et necessarie asper oleaster oritur; etiam de papauere ficus gratissimae et suauissimae uentosa et uana caprificus exsurgit. 8. Ita et haereses de nostro frutice, non nostro genere, ueritatis grano sed mendacio siluestres (de praescr 36. 7-8.). ${ }^{4}$

The vegetation complex is so congenial to Tertullian that he can easily develop the biblical imagery of Is. 11. 1-2, ..Christum..in floris figura.. (adu. Marc. 5. 8.4; cf. de carn. 21. 4-7, where fructus uteri of Luc. 1.42 is related to $I s .11 .1$, and where we find the same use of vegetation imagery used to express identity and development).

In this complex of imagery, we see how Tertullian draws on classical and biblical sources, and how the one imperceptibly joins the other; how Tertullian expands upon an image in a logical, but somewhat overdeveloped way; and how he uses this imagery for certain effects. The chief accents seem to be upon the connotation of sterile fecundity, and upon identity in the midst of development. ${ }^{5}$

1 See Adolf von Harnack, Marcion: das Evangelium vom fremden Gott ${ }^{2}$, Leipzig, 1924, note ad Luc. 6.40, p. 194*-195*.

See, e.g.: adu. Hermog. 13.1; adu. Marc. 1. 2.1 ; 2.2; 2. 4.2; 24.3; 4. 17.11; de cam. 8.4, etc.

Cf. Verg., georg. 2.314: '..infelix superat foliis oleaster amaris'.

- One other, and different usage, is found in de coron. 7.4.

- The idea of the Church as God's plantation is not present in Tertullian. Related to this, perhaps, is the '..lignum passionis Christi..', contrasted with the '..illud lignum in paradiso..', adu. Iud. 13.11. But this is not clear. Cf. JEan DaniÉlou, Die Kirche: Pflanzung des Vaters. Zur Kirchenfrömmigkeit der frühen Christenheit, in: Sentire Ecclesiam 


\section{The Sea. Water and the Spirit}

It is well known that, in Roman literature generally, the sea is regarded as a unfriendly element. ${ }^{1}$ From Plautus on, it is customary to regard sea voyages as dangerous, and to be avoided. ${ }^{2}$ The invention of sea faring, symbolised by the Argo, is thought of as evil, from Ennius ${ }^{3}$ to Lucretius $^{4}$ and Vergil ${ }^{5}$. Horace is particularly distrustful. ${ }^{6}$ The peoples living about the Mediterranean could hardly fail to be deeply impressed by the sea; here, as usual, an absolute dichotomy between 'classical' and 'biblical' imagery is impossible. Tertullian draws on both, however, in different ways.

He takes examples from sea faring (ad nat. 2. 5.1; de resurr. 60. 6-7); philosophers sometimes have hit upon the truth, as ships which find harbor, '..prospero errore..' (de anim. 2.1); even the quiet, peaceful death is a shipwreck (de anim. 42.5). ${ }^{\circ}$ The theme of sea and shipwreck is a typical case where classical and biblical inspiration merge. Cicero is very fond of the shipwreck theme, and he uses it most often in political connections. ${ }^{8}$ Paul was able to use it in 1. Tim. 1.19 in a not unrelated way ${ }^{9}$; and when Tertullian then, uses the image in allusion to the Pauline passage, the shipwreck theme has a deeper significance, as in de idol. 11.1, or later in the de idol., when we find an elaborate figure:

(Festschrift Hugo Rahner) herausgegeb. von Jean Dantélou und Herbert VorGRMLER, Herder, 1961, p. 92-103.

1 There are many studies on the sea theme in Latin literature. Here may be mentioned: Mona P. Hodnetr, The Sea in Roman Poetry, The Classical Journal 15 (19191920), p. 67-82 ; Nicola I. Herescu, Un theme traditionnel de la poesie latine : le naufrage, Rivista Clasica 4 (1942-1933) p. 119-137; E. DE SALNT-Denis, Le role de la mer dans la poessie latine, (Thèse, Paris) Lyon, 1935; H. H. Huxley, The Perils and Penalties of Seafaring : a stock Theme in Latin Poetry, Proceedings of the Leeds Philosophical and Literary Society, Lit. and Hist. sect. 6, part 8 (1951), p. 576-582.

Red. 485.

3ee Mona P. Hodnett, The Sea in Roman Poetry, CJ 15 (1919-1920), p. 67-68.

- de rer. nat. 5. 1006. Lucretius also is interesting for his use of sea imagery. His famous figure of the human condition is that of a castaway: '..ut saeuitus proiectus ab undis/nauita..' (5. 222-223) ; human 'progress' is ambiguously described in terms of in altum (5. 1434); there are many other references also.

s ecl. 4. 31-35.

- M. HodNETT, art. cil., p. 73 lists some of the adjectives which the later Horace used to describe the sea: uentosus, belwosus, auarus, raucus, inquietens, improbus, ater, turgidus, furens, dissociabilis, naufragus, asperus, imperiosus, feruidus, etc.

7 See J. H. Waszink, De Anima, note ad de anim. 52.4, p. 538-539.

- Cicero, de inuent. 1.4; pro dom. 129: '..in illo rei publicae naufragio..'; ibid. 136137: '....tu procella patriae, turbo ac tempestas pacis atque otii, quod in naufragio rei publicae...'; Phil. 2. 92: '...omnia te gubemante naufragia metuebam...'; and many other examples.

- See W. Straur, Die Bildersprache des Apostels Paulus, Tübingen, 1937, p. 27 and note one, ibid. 
Inter hos scopulos et sinus, inter haec uada et freta idololatriae uelificata spiritu dei fides nauigat, tuta si cauta, secura si attonita. Ceterum inenatibile excussis profundum est, inextricabile inpactis naufragium est, inrespirabile deuoratis hypobrychium in idololatria. Quicumque fluctus eius offocant, omnis uertex eius ad inferos desorbet (de idol. 24.1).

It is typical of Tertullian that the imagery here has a deeper layer of meaning; that naufragium has been deepened, and that ad inferos affords him the opportunity for a play on words. And the same logical development of imagery we find again in de pudic. 13. 19-20: 'a fide in blasphemiam mersos. 20. Unde et naufragos eos iuxta fidem pronuntiauit, non habentes solacium nauis ecclesiae.'

In the citation here, Tertullian immediately makes the connection with the nauis ecclesiae; in de idol. 24.4, with the Ark. We will return to the ship as figure of the Church shortly.

When Tertullian chides Marcion's theology: 'Duos Ponticus deos adfert, tamquam duas Symplegadas naufragii sui..' (adu. Marc. 1. 2.1), classical source and biblical source come together again ${ }^{1}$; Tertullian never forgets that Marcion came to Rome as a ship-owner or captain, and he mocks Marcion with the title of nauclerus (de praescr. 30.1; adu. Marc. 1. $18.4 ; 3.6 .3 ; 4.9 .2 ; 5.1 .2)$. Marcion's homeland suggests imagery: 'Haesisti, Marcion, in medio Ponti tui aestu. Utrimque te fuctus ueritatis inuoluunt.' (adu. Marc. 1. 7.7). Homeland and occupation of Marcion suggest the imagery, then: '..Pontice nauclere, si numquam furtiuas merces uel inlicitas in acatos tuas recepisti, si numquam omnino onus auertisti uel adulterasti, cautior utique et fidelior in dei rebus edam uelim nobis, quo symbolo ${ }^{2}$ susceperis apostolum Paulum...' (adu. Marc. 5. 1.2). ${ }^{3}$

Just as the occupations of Marcion, and of Hermogenes ${ }^{4}$ suggest themes of imagery, so some of Tertullian's works are built about given themes. As we will see the scorpiace uses medical imagery as the very model of the work; the de idololatria, de spectaculis have recurring motifs also. Sea imagery forms the chief axis of imagery in the de paenitentia. This note is sounded in the opening lines: 'Itaque uniuersam uitae conuersationem sine gubernaculo rationis transfretantes inminentem saeculo procellam

1 Biblical source, in that 1 Tim. 1.19 is certainly meant, and not the commonplace of naufragium; classical, in Symplegadas: of. Pliny, nat. hist. 4.13 (92).

'On symbolum here see ADHÉmar D'Alk̀s, Tertullien, symbolum, Recherches de sciences religieuses 20 (1936), 468.

3 Tertullian puns on the two meanings of sinus, in a field where sea imagery is suggested: '..sinum et portum..' (adu. Marc. 4. 34.11).

4 Tertullian never neglects the opportunity to make mocking references to Hermogenes' occupation of painter. See: e.g.: adu. Hermog. 2.1 ; 36.2; 38.1; 45.6; cf. de anim. 36.3 ; de monog. 16.1. This enables him to play on the word linea: adu. Hermog. 36.2 ; $38.1,3 ; 39.1$; and color: adu. Hermog. 33.1 . 
euitare non norunt.' (de paenit. 1.3). Gubernaculum ${ }^{1}$ and procella ${ }^{2}$ belong to themes of sea imagery which we find in Roman literature; the latter, however appears here in a deepened, eschatological sense. Life as sea faring, sin as shipwreck, penitence as tabula which saves: such is the obvious metaphor throughout the de paenitentia. One of the relatively few examples of a thoroughly mixed figure occurs in this context:

..ita amplexare ut naufragus alicuius tabulae fidem. 3. Haec te peccatorum fluctibus mersum proleuabit et in portum diuinae clementiae protelabit. Rape occasionem inopinatae felicitatis, ut ille tu nihil quondam penes dominum nisi stilla situlae et areae puluis et uasculum figuli arbor exinde fias, illa arbor quae penes aquas seritur et in foliis perennat et tempore suo fructus agit, quae non ignem, non securem uidebit (de paenil. 4. 2-3).

Here Tertullian departs from his normal practice, and without logical unity, unites biblical images. We pass from the dangerous sea to the beneficial water; from the insignificant drop to the abundance of water which means living, fruitful vegetation. Highly biblical also is the example of the Red Sea, which meant destruction for the Egyptian imperator, but through which the people passed safely (de paenit. 12.8). In the earlier part of the tract, paenitentia was described as the tabula which saves the shipwreck. Expanding on this, Tertullian speaks of paenitentia and exomologesis in the same imagery, but with different terminology: 'Quid ego ultra de istis duabus humanae salutis quasi plancis...' (de paenit. 12.9)..$^{3}$ Finally, he mentions the example of the man once saved from the sea, and who bids it a symbolic farewell: 'Plerique naufragio liberati

1 Seneca philosophus likes the figure gubernaculum: ep. 16.3: '..philosophia sedet ad gubernaculum et per ancipitia fluctuantium dirigit cursum.'; ep. 107.10: '. Iouem, cuius gubernaculo moles ista derigitur..' The word is usually found in the plural, and only a few instances of the singular are found before Tertullian. After Tertullian, singular and plural are found, and the figure becomes a favorite in Christian writers.

2 Cicero, pro dom. 136: '..tu procella patriae..'; pro Mil. 2.5: '..procellas in illis fuctibus concionum..', etc. A passage from Seneca may here be quoted, for a good example of the sea-figure as applied to the human condition. Dial. 11.9.6: '.. si uelis credere altius ueritatem intuentibus, omnis uita supplicium est: in hoc profundum inquietumque proiecti mare, alternis aestibus reciprocum et modo adleuans nos subitis incrementis, modo maioribus damnis deferens adsidueque iactans, numquam stabili consistimus loco: pendemus et fluctuamur et alter in alterum inlidimur et aliquando naufragium facimus, semper timemus; in hoc tam procelloso et in omnes tempestates exposito mari nauigantibus nullus portus nisi mortis est.'.

3 Tertullian is the first to use planca. Previously he uses the more ordinary tabula; as Cicero used it in contexts similar to those already quoted. Examples: de off 3. 89: '..si tabulam de naufragio stultus arripuerit, extorquebitne eam sapiens, si potuit?' ad Att.4. 19: '..haec enim me una ex hoc naufragio tabula delectat..'. Ovid; Trist. 1.6.8: '..naufragii tabulas..'. See also: William P. Le Saint, Tertulliar: Treatises on Penance. On Penance and On Purity. Westminster, London, 1959 (ACW 28), p. 149-150, note 54; and especially, Hugo Rahner, Der Schiffbruth und die Planke des Heils, Symbole der Kirche: Ekklesiologie der Väter, Salzburg, 1964, p. 432-472 (cf. ZKTh 79 (1957), p. 129-169); Das Meer der Welt, Symbole der Kirche, p. 272-303 (cf. ZKTh 66 (1942), p. 89-118). 
exinde repudium et naui et mari dicunt et dei beneficium, salutem suam scilicet, memoria periculi honorant.' (de paenit. 7.4) - and this reminds one of a parallel in Horace. ${ }^{1}$

A theme of water imagery runs through the de paenitentia; this theme draws on images which were frequent in Roman literature. But the images have been enriched in Tertullian, by their added biblical associations.

It is obvious that water must play a great role in the de baptismo. Tertullian devotes a section to the place of water in the history of salvation (de bapt. 9); the ambivalence of water appears there, also (9.1); he returns to the subject, from another point of view in $a d u$. Marc. 4. 20.1-3. These passages typify Tertullian's ability to range through scripture, unifying it along given themes. A famous passage from the de baptismo is of special interest:

Alii plane satis coacte iniciunt tunc apostolos baptismi uicem implesse cum in nauicula fluctibus mergerentur; ipsum quoque Petrum (per) mare ingredientem satis mersum. Ut opinor autem, aliud est adspergi uel intercipi uiolentia maris aliud tingui disciplina religionis. 7. Ceterum nauicula illa figuram ecclesiae praeferebat quod in mari, id est in saeculo, fuctibus id est persecutionibus et temptationibus inquietetur domino per patientiam uelut dormiente, donec orationibus sanctorum in ultimis suscitatus compescat saeculum et tranquillitatem suis reddat (de bapt. 12. 6-7).

Even at this early date, a catechetical tract on baptism is already handling problems like this one: when were the apostles baptised? Tertullian is not happy with an exegesis of Matth. 8.23-26, with the incident Matth. 14. 28-31 added. He sees the storm tossed ship as a figure of the Church. The reading which Tertullian rejects finds iconographical confirmation in a fresco in the house church at DuraEuropos, ${ }^{2}$ and the incident of Peter sinking in the water, and being rescued by Christ is put into a baptismal context by the Latin ritual of Baptism. Tertullian, then, would seem to be testifying to a tradition which might have found its first expression in the East. To this, he opposes another exegesis: the ship as figure of the Church. While E. Peterson suggests that the figure ultimately has roots in Jewish tradition $^{3}, \mathrm{~K}$. Goldammer recommends caution in this attribution. Goldammer points out how widespread the ship figure was in a polit-

1 Horace, carm. 5. 11-16.

2 See F. van der Meer and Christine Mohrmann, Atlas of the Ancient Christian World, London and Edinburgh, 1958, p. 42 for a reproduction of the Dura fresco.

- Erik Peterson, Das Schiff als Symbol der Kirche: die Tat des Messias im eschatologischen Meeressturm in der jüdischen und allchristlichen Ueberlieferung, Theologische Zeitschrift 6 (1950), p. 77-79. 
ical meaning ${ }^{1}$; an exclusive rooting of the ship in either tradition is impossible. Yet the clear eschatological significance of the figure, as used here by Tertullian, shows a source other than the merely classical. Tertullian is, however, a man of both worlds, and something of the classical use of this imagery is always present. The Ark is exclusively biblical (de bapt. 8.4; de idol. 24.4, etc.); the ship is common to biblical and classical traditions, and its use here is clearly influenced by nonclassical significance.

Tertullian is laboriously detailed in his explanation of the figure; somewhat in contrast to his later, limiting rules (cf. de pudic. 9. 1-3).

water and the spirit Tertullian sees in the Baptism of Christ the blessing of water (adu. Iud. 8.14; cf. de bapt. 9.3; cf. de pudic. 6. 15-16), in a tradition that is as old as Ignatius of Antioch. ${ }^{3}$ Water is naturally so central in the de bapt., that the tract risks becoming a laudes aquae. (de bapt. 3.6). As we have seen, Tertullian is very much aware of the biblical role of water (de bapt. 9; adu. Marc. 4. 20.1-3, etc.). One single aspect of this imagery interests us here: water as imaging inspiration, and associated with Scripture and the Spirit. The Muses, too, were associated with springs (Castalia, Aganippe, Hippocrene), and we have to do with a natural symbol, and one which is not necessarily exclusively biblical. But Tertullian is wholly biblical here in his inspiration, and the imagery of water is, with striking frequency, associated in Tertullian's mind with Scripture and the Spirit.

Expressing the common apologetic idea that the philosophers of antiquity owed their knowledge to some contact with Scripture, Tertullian describes this in imagery of water: 'Quis poetarum, quis sophistarum, qui non de prophetarum fonte potauerit? Unde igitur et philosophi sitim ingenii sui rigauerunt..' (apol. 47.2). We find here a remarkable constant, which runs through Tertullian. The (Roman) church '..legem et prophetas cum euangelicis et apostolicis litteris miscet, inde potat fidem..' (de praescr. 36.5); catechumens '..incipiunt diuinis sermonibus aures rigare..' (de paenit. 6.1). Now, while there are parallels in earlier Roman literature for

1 Kurt Goldammer, Das Schiff der Kirche, ein antiker Symbolbegriff aus der politischen Metaphorik in eschatologischer und ekklesiologischer Umdeutung, Theologische Zeitschrift 6 (1950), p. 232-237.

2 On the ship figure, see also: F. J. Dölger, Das Schiff der Kirche, in: Sol Salutis, Münster, 1925', p. 272-279; K. Goldammer, Navis Ecclesiae. Eine unbekannte altchristliche Darstellung der Schiffsallegorie, ZNTW 40 (1941), p. 76-86; JEAN DaNiÉLou, Le navire de l'église, in: Les symboles chrétiens primitifs, Paris, 1961, p. 65-76; Hugo Rahner, Das Schiff aus Holz: das Schifflein des Petrus, in: Symbole der Kirche, Salzburg, 1964 , p. 472-503; cf. ZKTh 66 (1942) p. 196-227; 69 (1947), p. 1-35.

I To the Ephesians, 18.2 . 
this imagery - notably for rigare, in the citation from apol. $47.2^{1}$, as also for potare ${ }^{2}$ - it is the constant association that Tertullian makes between this axis of imagery and Scripture and the Spirit which is striking. Qui legeris, biberis (scorp. 1.12); this text is to be seen in the larger context of the figure sustained throughout the scorpiace, the saving potion; in any case, the passage is made immediately to Scripture: 'Si eloquia domini dulcia...' (scorp. 1.12). To come to a complete knowledge of Paul is expressed in similar imagery: 'Si uis omnem notitiam apostoli ebibere..' (de pudic. 16.12). The latter section of the adu. Iud. offers a particularly elaborate form of this imagery, applied to the knowledge of Scripture, and in the context of baptism:

Hoc enim lignum tunc in sacramento, cum Moyses aquam amaram indulcauit, unde populus, qui siti periebat in eremo, bibendo revixit, sicuti nos, qui de saeculi calamitatibus extracti, in quo commorabamur siti perientes, id est uerbo diuino 〈non〉 proluti, ligni passionis Christi per aquam baptismatis potantes fidem... (adu. Iud. 13.12) ${ }^{3}$.

Water plays an important role throughout the chapter (cf. 13.11); the author quotes $\mathrm{Fer} .2 .13$, and then interprets the imagery of the citation in the light if John 4.10,13; 'Indubitate non recipiendo Christum, fontem aquae uitae, lacus contritos coeperunt habere, id est synagogas..' (adu. Iud. 13.15, cf. 13.14). For the Spirit does not dwell in those synagogues, and the 'thirst for the divine spirit' was predicted of the dispersed Jews (adu. Iud. 13.15 ; 13.16, citing Is. 65.13-15). The imagery then continues, always based on Scripture: drought, the absence of God; water, the presence of his Spirit. The ne pluerent imbrem of Is. 5.6 is explained: '..mandatum et nubibus.... id est caelestibus beneficiis..' (adu. Iud. 13.25).

This last citation brings us to another facet of Tertullian's use of biblical imagery: his conscious reflections on its meaning. Much as he is aware of the otherness of biblical language, he is also alert to the importance of the special imaginative language of the Bible. He would explain, not only the words of the prophecies, but also the things with 1 The author of the rhetorical treatise, ad Her. has a similar use of rigare: Rhet. ad Her. 4. 6.9: 'Isti cum non modo dominos se fontium, sed se ipsos fontes esse dicunt et omnium rigare debent ingenia, non putant fore ridiculum, si cum id polliceantur, arescant ipsi siccitate?" Besides the apol. 47.2 reference, rigare is used in Tertullian always more or less in a religious connection, as in the de paenit. 6.1 reference, also noted above: adu. Marc. 1. $13.4 ; 28.4 ; 4.13 .4 ;$ adu. Iud. 13.11 .

2 See, for example, Cicero, Tusc. 5. 13: '.tamquam leuia quaedam uina nihil ualent in aqua, sic Sloicorum ista magis gustata quam potata delectant..'.

3 The 13th chapter of the adu. Iud. is generally accepted as the genuine work of Tertullian. See Gösta Särlund, De pallio und die stilistische Entwicklung Tertullians (Skrifter Utgivna av Svenska Institutet i Rom, 8 (viii), Lund, 1955, esp. p. 162-166; Hermann TränkLe, Q.S.F. Tertulliani advetsus Iudaeos, Wiesbaden, 1964; Einleitung, p. xlvii and passim. 
which they proclaim Christ: 'Totidem enim apostoli portendebantur, proinde ut fontes et amnes rigaturi aridum retro et desertum a notitia 〈dei〉 orbem nationum, sicut et per Esaiam: ponam in terra inaquosa flumina - ...' (adu. Marc. 4. 13.4). Because the Jews reject the possibility of an allegorical interpretation, they miss the deeper significance of this language of Scripture: '..ignorantes et panem de caelesti repromissum et oleum diuinae unctionis et aquam spiritus...' (de resurr. 26.10). Here, Tertullian has the central Christian sacraments in mind. In this last reflection, he makes the connection between water and the Spirit explicit. This is not remarkable; what is interesting is the constant water imagery which he uses, without conscious advertence to it, throughout his works. $\mathrm{He}$ is never far from the scriptural sources of it: '..qui unum spiritum biberunt sanctitatis..' seems to reflect 1 Cor. 10.4 (apol. 39.9).

As, in the beginning, the Spirit of God was borne above the waters (Gen. 1.1; de bapt. 4.1, et passim), so, now: '..superque baptismi aquas tanquam pristinam sedem recognoscens..' (de bapt. 8.3). Tertullian is quite aware of the important role that water played in pagan religions, also: 'Sedenim nationes extraneae ab omni intellectu spiritalium potestatem eadem efficacia idolis suis subministrant. Sed uiduis aquis sibi mentiuntur...' (de bapt. 5.1).

Tertullian, it is true, held that the Spirit is not received in the water of Baptism (de bapt. 6.1); but his imagery is profoundly true to the Bible in associating water and the Spirit constantly. The great text for Tertullian, especially in his Montanist period, becomes foel 3.1 (cited in Acts 2.17, but cited by Tertullian as Joel) : '. .in nouissimis diebus effundam de meo spiritu in omnem carnem..' (adu. Marc. 5. 4.2; cf. 5. 4.4; 5. 8.6; $11.4 ; 17.4$, etc.). The effundam of the opening words of this prophecy is still appreciated by Tertullian, and he elaborates it in terms of imagery of water. Alluding to $\mathcal{F}_{0 e l}$, he uses imagery which places the text and the grant of prophetic graces in parallel with the language of Matth. 5.45: '...liberalitas soleat et in profanos destillare, imbres etiam et soles suos peraequante deo iustis et iniustis...' (de anim. 47.2). Again, he unites Scripture along an image. The best development of the water-Spirit complex in Tertullian is found in the closing lines of the de resurrectione. Departing from the Joel text, we see the logical unity which Tertullian generally succeeds in preserving in the fullness of his imaginative powers:

Atenim deus omnipotens aduersus haec incredulitatis et peruersitatis ingenia providentissima gratia sua effundens in nouissimis diebus de suo spiritu in omnem carnem...et fidem laborantem resurrectionis carnalis animauit...

9. Sed quoniam nec dissimulare spiritum sanctum oportebat, quominus et huiusmodi eloquiis superinundaret, quae nullis haereticorum uersutiis semina subspargerent, 
immo et ueteres eorum cespites uellerent, idcirco iam omnes retro ambiguitates et quantas uolunt parabolas aperta atque perspicua totius sacramenti praedicatione discussit per nouam prophetiam de paraclito inundantem.

10. Cuius si hauseris fontem, nullam poteris sitire doctrinam, nullus te ardor exuret quaestionum: resurrectionem quoque carnis usquequaque potando refrigerabis (de resurr. 63. 7-10).

The unity of the imaginative language is apparent. This passage demonstrates Tertullian's feeling for the imagery of water and the Spirit, water and the intelligence of the Scripture. Departing from the Joel text, he continues to use the imagery in a consistent way. An unnoticed allusion to Is. 12.3 (cf. adu. Marc. 4. 14.2), 'Cuius si hauseris fontem...' occurs naturally in the context of water imagery. Haurire ${ }^{1}$, in fact, fits into this complex elsewhere, also. Effundere is almost wholly laden, in Tertullian, with allusions to Joel, or to this general axis of imagery ${ }^{2}$ : and the verb which we saw in an earlier text, destillare, is always used with reference to scriptural texts. ${ }^{3}$ This indicates how profoundly biblical this imagery and its vocabulary has become in Tertullian. Superinundare ${ }^{4}$ seems to be an invention of Tertullian.

Concluding this section, therefore: the imagery of the sea in Tertullian shows clearly how inextricably bound up with one another are biblical and classical Latin sources. A radical separation of the two sources is, of course, impossible. But the imagery of the sea has added significance for Tertullian from its biblical overtones. With the special use of the imagery of water, the case is other. Here his inspiration is massively biblical. In a quite natural way, he constantly expresses the

1 Haurire is used figuratively very frequently by Cicero: de orat. 1. 46.203: '.. fontes, unde hauriretis...'; ad fam. 6. 6.9; '..eodem fonle haurire laudes suas...', etc. For some interesting figurative uses in Tertullian, with reference to Scripture, etc., see: apol. 15.8: '..omnem hine sacramenli ordinem haurite...'; adu. Marc. 4. 5.1; de anim. 2.3; de pudic. 10.13: '..Pastoris scripturam haurio..'’

${ }^{2}$ Effundere is used in non-scriptural connections in Tertullian in: ad nat. 1.10.1; apol. 4.9 ; praescr. 14.1 ; adu. Marc. $1.5 .1 ; 23.3$ (though this is a suggestive usage); de anim. 25.2; scorp. 1.2; 9.5; de ieiun. 4.3. We find effundere in citations of Ps. 44.3 in: adu. Marc. 3. $7.5 ; 14.1 ;$ adu. Iud. $9.17 ; 14.5$. Over against these, we find effundere in citations of, or references to 70 el 3.1 : adu. Marc. $5.4 .2 ; 4.4 ; 8.6(2 \times) ; 11.4 ; 17.4$; de resurr. 10.2; 63.7; adu. Prax. 30.5; de fug. 6.4. Finally, when Tertullian says, critically: 'At tu iam et in martyras tuos effundis hanc potestatem', where the power of forgiving sins is meant, we find a particularly interesting usage.

3 We find destillare in: adu. Marc. 3. 5.3, of 7oel 3.18; 5.9.10, of Ps. 71.6; de anim. 47.2, in the text cited above, of Joel 3.1 and Matth. 5.45.

1 According to the files of the ThLL, Tertullian is the first to use superinundare. In addition to the text de resurr. 63.9, cited above, one may also note apol. 18.2: 'Viros...a primordio in saeculum emisit spiritu diuino inundatos...' Cf. Petronius, Sat. 118.3: 'Ceterum neque generosior spiritus uanitatem amal, neque concipere aut edere partum mens potest nisi ingenti flumine litteranum inundata.' 
relation of water with the Spirit ${ }^{1}$ and the understanding of the scriptures. So deeply impregnated with this association is he, that some of his words are used exclusively, or almost so, to this purpose.

For both themes is valid what was noticed with the theme of vegetation: Tertullian is quite generally logical and unified in the articulation of images; and given axes of imagery have a constant function in his works. This is especially clear for the theme of sterile fecundity, in vegetation, and for the theme of water in the context of the Spirit and Scripture.

\section{Bestiary Themes}

In that collection of science, mythology, and moralising which was the medieval bestiary, we find the expression of an ancient tradition, which goes back, through the Fathers - through Ambrose, especially - to Pliny the Elder, and to the Bible. Tertullian fits into this tradition. He appeals frequently to the animal world for illustrations, and examples, which he took from the learning available to him. Here again, the two worlds, classical and biblical, meet. If, often, these illustrations are simple enough, and very like that lore which we find in Pliny's Natural History, there is also an important element of symbolism present. We can best begin with the various examples which Tertullian takes from animals. ${ }^{2}$ They are cited with the same quasi-scientific, moralising intent which is seen in the bestiaries. ${ }^{3}$ We are hardly in the realm of metaphorical language here; yet, as will appear, we move toward it, in that animals, in both biblical and classical contexts, have the value of symbols.

examples from bestiary themes. In a context of medical imagery, Tertullian cites the example of the stag, who, when wounded, knows how to rid himself of the arrow and to be cured, by eating dictamnum; this

1 See Wolpang Bender, Die Lehre aber den Heiligen Geist, (Münchener Theologische Studien, I.18), München, 1961. Bender examines the symbolism of water in the de bapt., p. 123-126; and the various expressions of the gift of the Spirit, p. 130-135; but not water imagery, expressive of the Spirit and Scripture.

2 See Hélène PÉtré, L'exemplum chez Tertullien, Neuilly-sur-Seine, no date, ch. 2, Les exemples empruntés à la nature, p. 31-51. Mlle Pétré approaches the bestiary themes from the standpoint of the rhetorical exempla. But there is more here than simple examples, as she notes; there is also the quasi-scientific learning of the contemporaries of Tertullien, notably, of Apuleius. Here also, Mlle PEtré notes the crossing of sources; of Pliny's Natural History, and the Bible.

a A popular translation of one medieval bestiary is to be found in the entertaining book of T. H. WhITE, The Bestiary, New York, 1954; reprinted, Capricorn Books, 1960). Here, the further tradition of most of the animals cited by Tertullian can be found. 
natural knowledge is an example to the Christian, wounded by $\sin ^{1}{ }^{1}$ In the same passage, another example is found in the swallow, who heals her blinded young with the herb chelidoria ${ }^{2}$ (de paenit. 12.6). In another bestiary series, we find the stag again (de pall. 3. 1-3;2) There, we are told, the stag, when aged, eats a snake, and '..languescit in iuuentutem...'3; taken from the Bible, the stag is the simple image, the simile of agility of the former lame (Is. 35.6: adu. Marc. 4. 24.12 (cf. adu. Iud. 9.30); de resurr. 20.6). Besides the stag, the peacock, serpent, and hyena all offer examples of change (de pall. 3. 1-3).4

As with sea imagery, the homeland of Marcion and its barbarous reputation suggest parallels with various animals. One passage is interesting for the implied etymological derivations, which also play a role in the bestiaries of later. Marcion, therefore, is like the beaver, and mouse: 'Quis enim tam castrator carris castor quam qui nuptias abstulit? Quis tam comesor mus Ponticus quam qui euangelia conrosit?' (adu. Marc. 1. 1.5). ${ }^{5}$ Marcion's contempt for the lower animals of creation is answered with a whole series of admiring examples by Tertullian (adu. Marc. 1. 14.1). ${ }^{6}$

Natural knowledge of beasts is exemplified again in the lion (de anim. 24.5). Here, there is no moral drawn; we are more in the atmosphere of the scientific. Tertullian draws on a whole tradition of real and imagined facts about the lion, also popular in the bestiary of later. ${ }^{7}$

More important, in Tertullian, however, is the animal lore drawn from the Bible. He makes the quite general prohibitions of the Law on kinds of fish specific with the mention of the sepia (Leu. 11.10; Dt. 14.10: adu. Marc. 2. 20.1). Tertullian probably found the example in general bestiary lore ${ }^{8}$; he roots it in the Bible, precisely against Marcion, and makes of it the figura of the rejection of heretics. It makes a useful image; the idea of complication, of darkness which is spread upon the '..relucentem bonitatem..' of the Creator, is typical of the associations which Tertullian favors when speaking of heretics. He is also able

${ }^{1}$ See Pliny, nat. hist. 8.41 (97).

nat. hist. 8.41 (98).

- Cf. Tatian, orat. ad Graecos 18.

4 On the peacock, see nat. hist. 10. 32 (43-44); serpents, Vergil, georg. 3. 437; the hyena, nat. hist. 8.19 (48-52).

5 nat. hist. 8.47 (109). While Pliny does not make the explicit etymological connection, the suggestion is there; which, in the bestiary, does become explicit. Cf. The Bestiary, p. 29. See Vergil, georg. 1. 58-59, also.

- Cr. nat. hist. $11.1(1-4)$ for Pliny's praise of the small animals.

? Cf. Lucretius, de rer. nat. 4. 712-713; nat. hist. 8. 19 (48-52); J. H. WAszink, De Anima, note ad de anim. 24.5 , p. 311-312.

8 nat. hist. 9.45 (84); cf. also H. Hoppe, Syntax und Stil des Tertullian, p. 199 and note ibid. 
to find a place in the Bible for the phoenix, by reading the poivt $\xi$ of Ps. 91.13 to mean 'phoenix', and not 'palm tree'. ${ }^{1}$ The prima Clementis had already used the phoenix as a proof of the resurrection, but without connecting it with the Greek text of Ps. 91.13.2 Tertullian cites the example as a testimony from nature to the resurrection (de resurr. 13. 1-3). Here he draws on an ancient, and complicated tradition. $\mathrm{He}$ immediately connects the phoenix with the birds of Matth. 10. 29-31: 'Multis passeribus antistare nos dominus pronuntiauit: si non et phoenicibus, nihil magnum.' (de resurr. 13.4); and these birds are favorite examples (de resurr. 35. 9-10; de exhort. 1.5; scorp. 9. 7-8; de fug. 3.2; de monog. 9.1).

The dog is unpopular even in the non-biblical reference of ad. nat. 2. 8.19 (cf. 2. 15.1). Most of the time, Tertullian contents himself with summary references to Matth. 7.6 (de praescr. 26.1; de bapt. 18.1), or to Matth. 15.26 (de praescr. 8.13; de orat. 6.3; adu. Marc. 4. 7.5; de fug. 6.3). The reference in Apoc. 22.15 is used twice (adu. Marc. 2. 5.1; de pudic. 19.9), and Tertullian expands on this in the adu. Marc. passage: 'Iam hinc ad quaestiones omnes, o canes, quas foras apostolus expellit, latrantes in deum ueritatis. Haec sunt argumentationum ossa, quae obroditis...' Here, again, Tertullian expands on an image logically.

animals as symbols. A highly interesting text from the de anima shows Tertullian reflecting on animals as symbolic of human mores:

Nam etsi quidam homines bestiis adaequantur pro qualitatibus morum et ingeniorum et affectuum, quia et deus: assimilatus est, inquit, homo inrationabilibus iumentis, non ideo milui ex rapacibus fient et canes ex spurcis et pantherae ex acerbis aut oues ex probis et hirundines ex garrulis et columbae ex pudicis... (de anim. 32.8).

Admitting the apparent correlation between various animals, and human characters, Tertullian denies that this is any proof of metempsychosis. The scriptural citation from $P$ s. $48.13,21$ finds other, similar comments in patristic literature. ${ }^{3}$ While the animals mentioned are not at all specifically biblically oriented ${ }^{4}$, the milui, canes, hirundines, and columbae all have biblical resonances; and it is typical of Tertullian

1 On the complicated history and development of the phoenix legend, see: JeAN Hubaux and Maxime Leroy, Le mythe du phenix dons les litteratures grecque et latine (Bibliothèque de la Faculté de Philosophie et Lettres de l'Université de Liège, fasc. LXXXII), Paris, Liège, 19-39. The authors also note a confusion between the Greek and Hebrew of Job. 29. 18, where the Hebrew chol is open to two translations: 'sand', or 'phoenix'. (Hubaux and Leroy, op. cit., p. 49).

On the text from Ps. 91.13, see p. 110, note one. Cf. also P. Boschi, Un vecchio simbolo della nostra resurrezione, La Civiltà Cattolica 99, II (1948), p. 19-28.

21 Clement 25, 1-5.

See J. H. Waszink, De Anima, note ad de anim. 32.8, p. 391.

- Ibid., p. 391-392. 
in the de anima that the argument departs from a biblical text. A useful contrast to this passage is found in the de idololatria:

Uiderimus enim si secundum arcae typum et coruus et miluus et lupus et canis et serpens in ecclesia erit. Certe idololatres in arcae typo non habetur. Nullum animal in idololatren figuratum est. Quod in arca non fuit, in ecclesia non sit (de idol. 24.4). Here again, the various animals represent human types and characters. However that may be, says Tertullian, no beast is the representation of the idololater; he is, therefore, not to be tolerated in the Church. The symbolic animals are here clearly rooted in the Bible.

serpents, etc. Of all symbolic beasts, the serpent and similar creatures are the most important in Tertullian. ${ }^{1}$ The Bible had already made, abundantly, the identification of the serpent and the devil (Gen. $3.1 \mathrm{ff}$; 2 Cor. 11.3; Apoc. 12.9). Tertullian draws heavily upon this theme. He is fond of elaborating upon it, following all the characteristics of reptiles. Occasionally a simple example of the bestiary sort (de pall. 3.2), the serpent appears most often in biblical context. A good example of such elaboration is found in ad mart. 1. 4-5:

Domus quidem diaboli est et carcer, in qua familiam suam continet. Sed uos in carcerem peruenistis, ut illum etiam in domo sua conculcetis. Iam enim foris congressi conculcaueratis. ..... Fugiat conspectum uestrum, et in ima sua delitescat contractus et torpens, tamquam coluber excantatus aut effumigatus.

It is possible that, in the conculcare ${ }^{2}$, we may see an allusion to Ps.90.13, which, in the adu. Marc. 4. 24.10, is applied to Christ:

..largitum hanc potestatem priori Christo suo, sicut nonagesimus psalmus ad eum: super aspidem et basiliscum incedes et conculcabis leonem et draconem sicut etiam Esaias : illa die superducet dominus deus machaeram sanctam magnam et fortem, Christum scilicet suum, in draconem illum, colubrum magnum et tortuosum, et interficiet eum illa die.

If, in fact, we find in the ad mart. passage an allusion to Ps. 90.13, then, in Tertullian, the two streams of exegesis of the verse are both represented: that which applied it to Christ, and that which applied it to the Christian. ${ }^{3}$ The text cited from adu. Marc. is preceded by a

1 See: H. Hoppe, Syntax und Stil, p. $174 \mathrm{ff}$; Barbara Renz, Die kluge Schlange, Biblische Zeitschrift 24 (1938-39), p. 236-241.

Tertullian, it will be seen, has introduced the adu. Marc. 4. 24.10 text with calcare, in 4.24.9. It is interesting to note that the other uses of conculcare in Tertullian all have reference to biblical texts, though not elsewhere to $P s .90 .13$, with the possible exception of ad mart. 5.1. Thus, ad uxor. 2. 5.2; adu. Marc. 4. 40.5, 6; de resurr. 22.4; $22.11 ; 31.4$.

'See: Balthasar Fischer, "Conculcabis leonem et draconem." Eine deutungsgeschichtliche Studie zur Verwendung von Psalm 90 in der Quadragesima, ZKTh 80 (1958), p. 421-429; p. 422-423, noting only adu. Marc. 4. 24.10. 
comment on serpent imagery in the Bible, to which we will have to return.

Departing from the games, Tertullian again expands upon the characteristics of the serpent-devil: ' $E$ t palaestrica diaboli negotium est: primos homines diabolus elisit. Ipse gestus colubrina uis est, tenax ad occupandum, tortuosa ad obligandum, liquida ad elabendum.' (de spect. 18.3). Here again, his subject matter suggests the imagery for Tertullian. Behind this also is the idea of the devil as adversary, and the Christian combat as an athletic contest. Again, the serpent, coiled, living deep in the ground, slow moving, complicated, fleeing the light (adu. Val. 2.1): all these characteristics of serpents and heretics have bad connotations for Tertullian. This passage is interesting, for it departs from the serpents and doves of Matth. 10.16, as poles of prudence and simplicity recommended to the Christian. This gospel image embarrasses Tertullian, and finally, he virtually disavows it, appealing to other biblical givens: 'In summa: columba demonstrare Christum solita est, serpens uero temptare; illa est a primordio diuinae pacis praeco, ille a primordio diuinae imaginis praedo.' (adu. Val. 2.4). So deeply does Tertullian feel the symbolic value of the serpent.

He returns, several times, to an explicitation of the symbolic value of the serpent in Scripture. The biblical meaning is read into the serpent that, legend claimed, guarded the Vestals: '...cum gentiles satanae suo et uirginitatis et uiduitatis sacerdotia perferant! Romae quidem quae ignis illius inextinguibilis imaginem tractant, auspacia poenae suae cum ipso dracone curantes, de uirginitate censentur.' (ad uxor. 1.6.3).

As already seen, in chapter one, Tertullian glosses the biblical serpens with a covering explanation (de idol. 5.4 ; de resurr. 28. 1-2; etc.). ${ }^{1}$ Uniting several texts - Ps. 90.13, Luc. 10.19, Is. 11. 8-9, Is. 27.1 - Tertullian reflects on the meaning of serpent imagery in the Bible. This is the text which we have just seen in relation with Ps. 90.13:

Quis nunc dabit potestatem calcandi super colubros et scorpios?... Sed bene, quod creator hanc potestatem etiam paruulis pueris per Esaiam repromisit, conicere manum in cauernam aspidum et in cubile natorum aspidum nec omnino laedi. 10. Et utique scimus - salua simplicitate scripturae, nam nec et ipsae bestiae nocere potuerunt, ubi fides fuerit - figurate scorpios et colubros portendi spiritalia malitiae, quorum ipse quoque princeps in serpentis et draconis et eminentissimae cuiusque bestiae nomine deputetur penes creatorem... (adu. Marc. 4. 24.9-10). There follows the citation on the preceding page. What is of interest here is the tension in Tertullian. He is quite aware of the symbolic value of serpents in Scripture, figurate; but he would also preserve the 1 See, supra, ch. 1, p. 31 
literal sense, if he possibly might. Here, again, he unifies Scripture along the lines of an image. The Isaian imagery of 11.8 occurs again in adu. Hermog. 11.3, signifying a return to the original order of creation; this, naturally, in the context of the argument with Hermogenes. No suggestion ever appears of the strikingly similar imagery of Vergil, ecl. 4. 19-25.

Themes of imagery cross constantly in Tertullian. Thus we find serpents, and similar beasts, characterised as seeking out the dry places, unlike the pisciculi ${ }^{1}$, who can live only in life giving water (de bapt. 1 . 2-3). The opening lines of the scorpiace is a highly developed application of the scorpion as figure of the Gnostics and Valentinians; 'Familiare periculi tempus aestas..' (scorp. 1.2); 'Cum igitur fides aestuat et ecclesia exuritur .. tunc Gnostici erumpunt..' (1.5). This time of heat (ardor) '..apud Christianos persecutio est' (1.5), and this dryness and heat, congenial to the beasts which symbolise the Gnostics, is itself biblically founded in its imagery: '..in parabola seminis post cespitem arefacti persecutionum figurat ardorem.' (scorp. 11.3); here the complexes of water, vegetation, and serpents all meet, in the peculiar consistency of Tertullian's imagery. Again, while Nicander, cited by Tertullian in the beginning of the scorpiace lends the medical model of the treatise, the symbolic value of the scorpions, etc., is much more biblically inspired.

Also connected with serpents are asps, vipers, etc. The odd alliance of Jews and heretics is described in terms of the popular science of the day: 'Desinant nunc haereticus a Iudaeo, aspis, quod aiunt, a uipera, mutuari uenenum, euomat iam hinc proprii ingenii uirus...' (adu. Marc. 3. 8.1).

Very different is the healing bronze serpent of $\mathcal{N u m}$. 21.9, to which Tertullian frequently alludes. ${ }^{2}$ But even here, the serpent-devil symbolism is present: 'An et hic dominicae crucis uim intentabat, qua serpens diabolus publicabatur et laeso cuique a spiritalibus colubris, intuenti tamen et credenti in eam, sanitas morsuum peccatorum et salus exinde praedicabatur?' (adu. Marc. 3. 18.7).

Other beasts are mentioned by Tertullian, usually with symbolic value. They seem to pray, in an attractive and genial passage from the closing lines of the de oratione: '..orat omnis creatura, orant pecudes et ferae et genua declinant et egredientes de stabulis ac speluncis ad caelum non otioso ore suspiciunt uibrantes spiritum suo more. Sed et aues tunc exurgentes eriguntur ad caelum et alarum crucem pro manibus expandunt et dicunt aliquid quod oratio 1 See: F. J. DöLGER, $I X \Theta Y \Sigma$ : Das Fischsymbol in frühchristlicher Zeit, Rom, 1910 ( $I X \Theta Y \Sigma$, Band I) ; Der heilige Fisch in den antiken Religionen und im Christentum, Münster, 1922 (IX®Y $\Sigma$, Band II); JEAN Dantélou, L'eau vive et le poisson, Les symboles chrétiens primitifs, Paris, 1961, p. 49-63.

2 See: adu. Marc. 2. 22.1; de idol. 5. 3-4; adu. Iud. 10.10. 
uideatur.' (de orat. 29.4). The adversary of the de baptismo is '..illa monstrosissima..' (de bapt. 1.3). In the same line are the '..nouae bestiae..similes pristinae..' (de bapt. 17.3). Lupus was not one of those animals which is symbolic of some human deportment (de anim. 32.8, see text, supra, p. 19), but is noted in the Ark; (de idol. 24.4, see text, supra, p. 85). The biblical matrix dominates: the lupi rapaces of Matth. 7.15 (de praescr. 4. 2-3): '..oues in medio luporum..' (Matth. 10.16: scorp. 9.4); the wolf that descends on the sheep, abandoned by the hireling ( $70 h .10 .12$ : de fug. 11. 2-3). The text Gen. 49.27, 'Beniamin..lupus rapax..' is a figure of the Apostle Paul (adu. Marc. 5. 1.5; scorp. 13.1). BibJical and 'bestiary sources come together in the interpretation which Tertullian, following Justin and Irenaeus 1 , makes of the text Deut. 33.17:2

tauri decor eius, cornua unicornis cornua eius, in eis nationes uentilabit pariter ad summum usque terrae, non utique rhinoceros destinabatur unicornis nec minotaurus bicornis, sed Christus in illo significabatur, taurus ob utramque dispositionem, aliis ferus ut iudex, aliis mansuetus ut saluator, cuius cornua essent crucis extima (adu. Marc. 3. 18.3).

That Tertullian sees here the symbolism of the cross, as also in the birds' wings in flight (de orat. 29.4: see text, supra, p. 87) is not simply due to his sources. He sees the cross everywhere. ${ }^{3}$

Here again, therefore, in the bestiary themes, we see Tertullian drawing on both sources; the common appreciation of the pagan world that beasts symbolised human mores, and, in a similar text to de anim. 32.8 (supra, p. 84), Tertullian reflects the Christian version of this insight, when he dwells on the Ark, and its contents, symbolic of the vices there symbolısed: idolatry, however, excepted (de idol. 24.4, see supra, p. 85). Quite in line with this reflex awareness of symbolic value are the reflections which Tertullian makes on serpents in biblical texts (adu. Marc. 4. 24.9-10; cf. 3. 18.7; de resurr. 28.2; de idol. 5.4). Passing on from the use of animals in exempla $a^{4}$, Tertullian draws not only on the quasi-scientific lore of his time, but also upon the Bible. He uses bestiary themes of imagery in much the same way as the medieval

1 See: Adhémar D'Arès, Tertullianea. Le thinoctros et le symbolisme de la croix, RSR 26 (1936), p. 99-100; Justin, Dial. 91. 2-3; Irenaeus, adu. haer. 2. 24.4.

a On rhinoceros and 'unicorn', see: OTto Keller, Die antike Tierwelt, II Vols., Leipzig, 1909; Pliny, nat. hist. 8.29 (71) ; 11. 106 (255).

a Tertullian sees the Cross in the inner framework used by image makers to strengthen their handiwork (ad nat. 1. 12.5-9); in the human body (de idol. 12.2); the frames of military banners are in the shape of the Cross, and so it is testified to by the religio casirensis (apol. 16.8); it is symbolised by the crossed hands of Joseph, blessing his sons (Gen. 48.14: de bapt. 18.2); Moses praying, and Isaac carrying the wood of sacrifice (adu. Marc. 3. 18.2-6); the tau of Ezechiel 9.4 (adu. Marc. 3. 22.5-6), etc.

4 See Helène Pétré, L'exemplum chez Tertullien, p. 31-51. 
bestiaries, and medieval art were to do, and Tertullian therefore takes an important place in the development of this tradition. ${ }^{1}$ It 1 s the Bible, and not Pliny, that dominates the bestiary matrix. And here again we see that crossing of sources. Notably in the imagery and symbolism of serpents, the Bible has changed the imaginative value of many of these themes. In his elaboration of the bestiary themes, Tertullian shows that peculiar logic of the imagination which has already been noted in his use of others, and which is so characteristic of him.

\section{Glothing}

Although the de pallio is concerned with the symbolic value of different garbs, this is a special question, which need not occupy us here. The clothing theme in Tertullian has profound biblical resonances, which far outweigh the classical. In Latin literature, clothing imagery is used to describe nature by Cicero ${ }^{2}$, Vergil ${ }^{3}$, and $\mathrm{Livy}^{4}$, for example; and Tertullian, too, speaks in this way: '...arbores uestire post spolia..' (de resurr. 12.4) ${ }^{5}$; 'Seritur enim solummodo granum sine folliculi ueste...' (de resurr. 52.8). But the resemblance, one should note, is superficial. For the de resurrectione employs clothing as a main axis of imagery and argument, departing from 1 Cor. 15.53, 2. Cor 5.2-4, and, as we shall see, the resurrection is one of the main contexts in which clothing imagery is employed in Tertullian.

Again, clothing imagery is used of rhetorical disposition by Cicero ${ }^{6}$, Quintilian ${ }^{7}$; much in the same way, Tertullian also uses it: '..communes sententias propriis argumentationibus uestiant...' (de anim. 2.5).

It is the biblical inspiration, however, which is strongest in Tertullian in this theme of imagery; and there are three great moments: Baptism, the Incarnation, and the resurrection. Clothing is an important religious symbol and axis of imagery generally; but no attention will be given to this important aspect. The interest here is on the consistency of the theme of clothing in Tertullian, and how it finds its inspiration in biblical sources to describe the three moments just mentioned.

1 ibid., p. 50-51; cf. T. H. WHTTE, The Bestiary, passim.

2 Cicero, arat. 473: '..et uestiuit lumine terras..'; de nat. deor. 2. 132: '..montes uestiti atque siluestres..'. ibid., 2. 98: '..terra..uestita floribus, herbis, arboribus, frugibus..'.

' Vergil, ed. 4.45: '..sponte sua sandyx pascentis uestiet agnos..'; georg. 2. 38: '...atque olea magnum uestire Tabumum.'; Aen. 6. 640: '..et lumine uestit purpureo..'.

Livy, 32. 13.3.

- Tertullian here reverses the feeling of Horace, for example, in carm. 4. 7.

- Cicero, Brut. 274: '..ita reconditas exquisitasque sententias mollis et pellucens uestiebat oratio..'

7 Quintilian, de inst. or. 8. proem. 20: ‘..res, quae illo uerborum habitu uestiuntur..'. 
There are incidental uses of clothing imagery; the lilies of the field text (Matth. 6.28 // Luc. 12.27) affords Tertullian the occasion to use biblically inspired imagery applied to nature, and he returns to this frequently (de orat. 1.1; ad uxor. 1. 4.7; adu. Marc. 4. 21.1; 4. 29.1-5; de idol. 12.2, etc.). The unity of the two testaments is described in imagery of clothing: 'Quomodo abscidit euangelium a lege, tota lege uestitus, in nomine scilicet Christi?' (adu. Marc. 3. 15.5; cf. also 4. 11.10). This figure departs from a text which Marcion seems to have used, to justify his separation of the two testaments: the patch of new cloth on old garments (Luc. 5.36 // Matth. 9.16). This is worth remarking, for it shows how strongly Tertullian is led by his imagination; even this familiar text is still imaginatively alive for him.

If some biblically oriented clothing images are difficult to localise in the Bible, they become clearer, when placed in the full context of the three moments of such imagery in Tertullian: Baptism, the Incarnation and the resurrection. Such texts are: the (Roman) Church robes her faith with the Holy Spirit: '..eam .... sancto spiritu vestit...' (de praeser. $36.5)$; the flesh clothes itself with the discipline and sacraments of God: '.... sacramentis suis disciplinisque uestiuit...' (de resurr. 9.1 : here, again, this imagery is ruled by the larger theme of clothing which runs through the de resurrectione). We have here to do with an extremcly elaborate, yet consistent, axis of imagery which runs through these three great moments. It seems best to trace clothing imagery throughout them twice; first, various figures which are used to describe Baptism, the Incarnation, and the resurrection; and then, retracing these motifs, to examine the texts using induere, superinduere.

If, before the New Testament, faith was nuda, it now receives a garb in Baptism: '...obsignatio baptismi, uestimentum quoddamodo fidei..' (de bapt. 13.2). Later, Tertullian speaks of this baptismal robe in terms of the parable of the prodigal: 'Recuperabit igitur et apostata uestem priorem, indumentum spiritus sancti, et anulum denuo, signaculum lauacri,....et recumbet eo in toro, de quo indigni uestiti a tortoribus solent tolli et abici in tenebras, nedum spoliati...' (de pudic. 9.11: drawing on Luc. 15.22, conflated with Matth. 22. 12-13). In the de pudicitia, Tertullian tries to apply the parable of the prodigal to the man who does not know God; and who, when he comes to know him, 'Recordatur patris Dei, satisfacto redit, uestem pristinam recipit, statum scilicet eum, quem Adam transgressus amiserat. Anulum quoque accipit tunc primum, quo fidei pactionem interrogatus obsignat...' (de pudic. 9.16; cf. also 20.7). To be baptised is to put on Christ, of course; but this brings us to induere, which is better treated apart.

All three moments depend on a central, continued metaphor: flesh as 
clothing. 'Uestitus exim animae caro..' (scorp. 12.10). This metaphor is constant, and underlies the imagery used to describe Baptism, the Incarnation and the resurrection (cf., e.g., de resurr. 7.6; de cult. fem. 2.2 .6 , by implication; adu. Val. $24.3 ; 32.2 ; 32.5)$. As in the question of the pallium, Tertullian is aware of the symbolic value of clothing, and he devotes some attention to the question (de resurr. 57.12; de coror. 8.3; de idol. 16. 1-2, etc.). And so, when he comes to describe the Incarnation, he naturally adopts clothing imagery. As, in Baptism, Christ clothes us with himself, 'Nos autem Jesus Christus summus sacerdos et magnus Patris de suo uestiens (quia qui in Christo tinguuntur, Christum induerunt)...' (de monog. 7.8), so he clothes himself with human flesh, in the Incarnation.

A curious figure which we have already seen in the complex of vegetation (supra, p. 69: de pudic. 6.16) occupies us now from the viewpoint of clothing imagery:

At ubi sermo Dei descendit in carnem ne nuptiis quidem resignatam et sermo caro factus est ne nuptiis quidem resignanda, quae ad lignum non incontinentiae, sed tolerantiae accederet, ....

quae non lasciuiae frondibus, sed sanctimoniae floribus praecingeretur, quae munditias suas aquis traderet, exinde caro quaecumque in Christo reliquas sordes pristinas soluit... (de pudic. 6.16).

An extremely dense text. Here again appears the relation of Incarnation add Baptism; and Tertullian allusively repeats his view that the waters were cleansed in the Baptism of Christ. ${ }^{1}$ The contrast, '..lasciuiae frondibus...sanctimoniae floribus' is a crossing of themes of imagery: that of sterile luxuriance, and fruitfulness in vegetation, with clothing imagery. Tertullian here views the fig leaves of Adam and Eve as symbolic of a certain depraved life, where Irenaeus saw them as signs of penitence ${ }^{2}$; Tertullian comments, just before the passage cited above. '..de ficulneis foliis pruriginem retinens....'3 A similar idea is found in de anim. 38.2: 'Ab his autem annis et suffusior et uestitior sexus est, et concupiscentia oculis arbitris utitur et commuricat placitum et intellegit quae sint et fines suos ad instar ficulneae contagionis prurigine accingit...." Again, even in the de pallio: 'Hunc (scl. hominem) quoque primordio accipitis, nudus certe et inuestis figulo suo constitit; post demum sapientiam, haud dum licitum, praereptam potitur. Ibidem quod in nouo corpore indebitum adhuc pudori erat protegere

1 See supra, p. 78.

Irenaeus, adu. haer. 3. 23.5.

- See Hugo Koch, Tertullianisches IV. 8: Die Feigenblätter der Stammeltern bei Irenäus und bei Tertullian und die Nachwirkung ihrer Erklärungen, Theologische Studien und Kritiken 104 (1932), p. 39-50; p. 40-41 on the ms. difficulty in the de pudic. passage. 4 See: H. J. Waszink, De Anima, note ad de anim. 38.2, p. 436-437, following H. Koch. 
festinans ficulneis foliis interim circumdat; dehine cum de originis loco exterminat, quippe deliquerat, pellitus orbi ut metallo datur.' (de pall. 3.4). These three texts show how aware Tertullian is of the significance of clothing; and it is secondary to our interests here that he also dwells on the 'milk' of the fig tree, and contrasts it with the water of baptism. ${ }^{1}$ The fig leaves and their interpretation depart from Gen. 3.7; Gen. 3.21 says that God made garments of skin for Adam and Eve, and this text is important for Tertullian, confirming his view of flesh as clothing (de cult. fem. 1. 1.2 ; adu. Val. 24.30; de resurr. 7. 2-6).

This excursus on the value of the fig leaves in the imagery of Tertullian started in a text which presented the Incarnation in imagery of clothing. It is easy to multiply texts which show that this view of the Incarnation is a constant in Tertullian. He explains the priestly garment of Aaron (Ex. 28.17-21), and reads the twelve precious stones which adorned it to mean the Apostles, who, '..ut gemmae inluminaturi sacram ecclesiae uestem, quam induit Christus, pontifex patris..' (adu. Marc. 4. 13.4). This text, whlle more profound than others, is quite in line with imagery which Tertullian easily founds in the Bible. Christ in the Old Testament was '..in carnis habitu non natae adhuc, quia nondum moriturae..' (de carn. 6.8). Here, again, Tertullian reflects on biblical imagery; the great source for him is the prefiguring of Christ in prophecy. First departing from Is. 63. 1-3, Tertullian explains:

Spiritus enim propheticus, uelut iam contemplabundus dominum ad passionem uenientem, carne scilicet uestitum ut in ea passum, cruentum habitum carnis in uestimentorum rubore designat...

He then goes on to Gen. 49. 10-11:

Multo marifestius Genesis in benedictione Iudae, ex cuius tribu carnis census Christi processurus, iam tunc Christum in Iuda deliniabat: lauabit, inquit, in uino stolam suam et in sanguine uuae amictum suum, stolam et amictum carnem demonstrans et uinum sanguinem (adu. Marc. 4. 40.6).

Here again, we find Tertullian reflecting on the meaning of biblical imagery. The two comings of Christ - the first in humility, the second in glory - formed a commonplace of the polemic with the Jews, and were expressed in the figures of the stone, the scapegoat, and, what interests us here, the imagery of clothing. This last is prominent in the following text, which is based on Zach. 3. 3-5:

..duplici habitu in duos aduentus deliniatur, primo sordidis indutus, id est carnis passibilis et mortalis indignitate, ... dehinc despoliatus pristinas sordes et exornatus podere et mitra et cidari munda, id est secundi aduentus gloria et honore (adu. Marc. 3. 7.6; cf. 7.1; 7.2-3).

1 Cf. H. Косн, art. cit., p. $40 \mathrm{ff}$. 
Still in the theme of the Incarnation, we find an interesting text, ascribed to Tertullian by the Praedestinatus (part of which was long ascribed to Augustine). Here, preserving the transcendence of the divinity in the Incarnation, the author compares the Incarnation to the descent of a king into a sewer, to retrieve a golden ring set with a jewel. He puts on a seruilem tunicam, and it is this which is soiled, and not the person of the king. The continued comparison makes the gem to be the soul, set in the golden ring of the body, the whole being humanity. (The text is to be found in the Fragmenta, IV; GC edition, p. 1335.) While such a comparison is not found elsewhere in Tertullian, its imagery is more or less consistent with that used by Tertullian. The two comings, therefore, of Christ, and the Incarnation alone, are regularly portrayed in imagery of clothing which is highly biblical in its inspiration, and the whole is to be seen in the full context of this imagery in Tertullian. For this motif, again, a second examination from the vantage point of induere will be necessary.

We come, finally, to the resurrection. Here, as we will see, Tertullian follows Paul very closely. The de resurrectione used two Pauline images prominently: that of the seed, (1 Cor. 15. 36-38), and that of the garment (suggested by 1 Cor. 15.53). The basic metaphor of the body as the clothing of the soul is elaborated upon in a curiously literal and detailed way, appealıng to several biblical loci (de resurr. $7.2-6) .{ }^{1}$ Here we again find a capital text, where Tertullian reflects on the meaning of biblical images:

Habemus etiam uestimentorum in scripturis mentionem ad spem carnis allegorizare, quia et apocalypsis Iohanris: Hi sunt, ait, qui uestimenta sua non coinquinauerunt cum mulieribus, uirgines scilicet significans et qui semetipsos castrauerunt propter regna caelorum. 2. Itaque in albis erunt uestibus, id est in claritate innubae carnis. Et in euangelio indumentum nuptiale sanctitas carnis agnosci potest. 3. Itaque Esaias docens, .... Tunc, inquit, lumen tuum temporaneum erumpet et uestimenta tua citius orientur, non subsericam utique nec pallium sed carnem uolens accipi, ortum carnis resurrectae de mortis occasu praedicauit ${ }^{2}$ (de resurr. 27. 1-3).

Just as with biblical language and expressions, Tertullian glosses 1 See F. J. Dölger, $I X \Theta Y \Sigma$, Rom, 1910, p. 116 ff.; W. Straue, Die Bildetsprache des Apostels Paulus, Tübingen, 1937, p. 24-25.

2 Tertullian reflects on the imagery of the color of clothing, as here, and de resurr. 57.12; ad uxor. 1. 7.4. The '..in albo apostolorum..' of adu. Marc. 5. 1.1 is probably rooted in biblical, rather than in classical symbolism; this against the reading of H. RönsCh, Das Neue Testament Tertullian's, p. 606, who appeals to the album senatorium, album iudicum, of Roman life. See also the comments on the clothing of the Pharisees, adu. Marc. 5. 20.6; further, the comments in de coron. 1.3 ; scorp. 12.8; 9-10; de idol. 18.1-2 and ff.; de pudic. 20.7. 
biblical images with an explanation of their deeper meaning. In the preceding chapter 26 , he explained the deeper meaning of other symbols, which the literal minded Jews do not understand; and he is constantly at grips with a false allegorical explanation of scriptural texts. In the passage just quoted, Tertullian's ability to range through Scripture, uniting it along images and themes, is again apparent.

Before terminating this first phase of the investigation, another text from the de resurrectione will serve to show a certain ambivalence in the imagery of Tertullian:

Oro te, si famulum tuum libertate mutuaueris, quia eadem caro atque anima permanebunt, quae flagellis et compedibus et stigmatibus obnoxiae retro fuerant, idcircone illas eadem pati oportebit? Non opinor. Atquin et uestis albae nitore et anuli aurei honore et patroni nomine ac tribu mensaque honoratur (de resurr. 57. 12).

Here, it seems that Tertullian is simply illustrating this case with an example and imagery from daily life in Roman North Africa: the manumission of slave, with the resultant significant change in dress. But, given the fact that the entire tract de resurrectione is ruled by biblically inspired clothing imagery, and given the baptismal significance of the anulus (de pudic. 9.11, 16, e.g.; see text, supra, p. 26), the biblical character of albus (see note 91, supra), it is very probable that this passage and its images are meant to be read in a biblical light; and then '..patroni nomize ${ }^{1}$ ac tribu mensaque...' also have a new value. In this way, Tertullian plays on the meaning of words and images, reading them in both 'classical' and 'biblical' contexts. Even here in the de resurrectione, he can show that he is at home in both traditions.

We have now to cover the same ground, that of the three moments, Baptism, Incarnation, and the resurrection; this time from the point of view of induere, superinduere, and related words.

Baptism. Gal. 3.27 uses a famous figure to describe the result of Baptism: "you have put on Christ". Paul here uses a figure which is frequent in the Bible (notably in the book of $\mathcal{J} o b: 7.5 ; 8.22 ; 29.12 ; 40.5$ ), and which expresses an intimate union. Paul uses the expression with regard to Christ elsewhere, also (Rom. 13.14; Eph. 4.24, nouum hominem; cf. Col. 3.10). It is used in a strong sense of identity, not of exterior seeming. As used by Paul, the expression certainly has no reference to the new clothing of the baptised, for this part of the rite is far later. Zahn suggested that the figure is taken from the theatre, and it then would

1 nomen is a good example of a word on the varied senses of which Tertullian plays. See: Christine Mohrmann, $A$ propos de deux mots controversés de la latinité chrétienne: Tropaeum - Nomen, VC 8 (1954), p. 154-173 (= ELC III, p. 331-350; p. 345-346). 
mean that the Christian takes on the role of Christ; but this is excluded by contemporary exegetes. ${ }^{1}$ Interestingly, Tertullian knows this usage of induere, uestire, in the religious sense of putting on the personage of a god. Thus, '. famosum..caput imago cuiuslibet dei uestit...' (ad nat. 1. 10.45; I/ apol. 15.3); '..Herculen induerat...' (ad nat. 1. 10.47; // apol. 15. 4-5; cf. de arim. 33.9). While we have simple uses of the word induere with reference to dress (often in biblical contexts: adu. Marc. 5. 18.12; de resurr. 7.2 ; scorp. 12.9; de uirg. uel. 16.4, etc.; less frequently in nonbiblical contexts: de idol. 15.11 ; de pudic. 22.1), the vast majority of the uses of induere have to do with the moments of Baptism and the Incarnation; while superinduere is used exclusively of the resurrection.

If the Scripture index of the CC edition lists 5 occurrences of Gal.3.27, allusions to the text are far more numerous. Such allusions are found, for example, in the following texts: '..qui ab apostolis fidem induerant.' (de praescr. 23.6); '..baptismum Christi induerit..' (de bapt. 12.2); '..qui baptismum eius induerunt..' (de anim. 50.2). These texts all have to do with baptism, and the Gal. 3.27 text is behind them. Similar is the idea in de paenit. 6.18: '..innocentiam induimus..'2 Now the image value of induere is still alive for Tertullian: '...Quid uestiris a nudo, si Christum induisti?' (de resurr. 3.4); '..de suo uestiens (quia qui in Christo tinguuntur, Christum induuntur.)' (de monog. 7.8). If one inquires what the value of this imagery is, in Tertullian's eyes, for the unity of Christ and Christian, one finds very strong texts in adu. Marc. 3. 12.4, de fug. 10.2.

He never illustrates the text from a clothing rite accompanying baptism. ${ }^{3}$ The imagery of Gal. 3.27 is very important to him, doctrinally, and it is still capable of stimulating his imagination. The clothing imagery seen in the first approach to the Baptism moment is generally in function of this word and image, induere.

Incarnation It does not seem that there is any one Scripture text from which Tertullian departs to present the Incarnation in the terms which he uses so frequently, induere carnem, and similar language.4 In

1 On the interpretation of Gal. 3.27, see: Ernest de WITt Burton, The Epistle to the Galatians, Edinburgh, 1921 (The International Critical Commentary), p. 204206, note ad 3.27; Heinrich Schler, Der Brief an die Galater, Göttingen, 1962 (Meyers Kommentar, VIII) p. 172-174, ad 3. 27.

2 The CC Scripture register notes: adu. Marc. 3. 12.4; de resurr. 3.4; de fug. 10.2; de monog. $8.7 ; 17.5$. In addition to the texts cited above, one may note: $a d u$. Val. 26.2; de resurr. $19.5 ; 26.11 ; 56.5$; de monog. 17.5 ; de pudic. 6.18 . In the texts de resurr. 3.4 , de monog. 17.5, Rom. 13.14 may be also seen.

- The passage from Justin, Dial. 116, may have reference to a garment rite; in any case, the parallel between rite and Gal. 3.27 is clear in Cyril of Jerusalem. Cat. Myst. $2.2,3.1$.

4ee: Rene Braun, Deus Christianorum, p. 310-317. Braun feels that Phil. 2.6 played a large role in Tertullian's predilection for the Incarnational formula, induere hominem, 
his effort to find a formulation of the Incarnation which would at once preserve the reality of the Incarnation, and yet would preserve the divine transcendence, induere carnem won pride of place. The reality of this assumed flesh is always a concern (adu. Marc. 1. 24.5). The example of the angels conversing with men, and appearing in human form, is at once a solution and a difficulty for Tertullian (adu. Marc. 3.9.1 and ff.; 3. 10.4-5; de carn. 3. 6-7; cf. de resurr. 62.1). To go into this would bring us into the theology of the Incarnation in Tertullian. ${ }^{1}$ It is enough to note that the formula, induere carnem, is in continuity with the use of texts like Gal. 3.27, and other Pauline texts; and that the clothing image is often prominent, as is evident from the earlier examination of this imagery in the context of the Incarnation. The imagery, which supplies Tertullian with a theological model, and which he adopts to save the divine transcendence (adu. Prax. 27.6), causes him some difficulties, also (de carn. 3. 4-7), for it is open to a 'docetist' reading. Induere still has an image value for Tertullian, and suggests other images to his logical imagination; the exact rooting of the induere formula in Scripture remains imprecise, but of the importance of the word in an Incarnational context, there can be no doubt. ${ }^{2}$

The resurrection. Here we have to do with superinduere, superindumentum; imagery of the resurrection which is biblically inspired, and quite consistent with that entire view of salvation economy in the three moments which we have seen; further, it is curiously consistent with the continued metaphor, the flesh as clothing of the soul.

Unsurprisingly, the resurrection moment is wholly rooted in Scripture, in two Pauline texts, 1 Cor. 15.53, and 2 Cor. 5. 2-4. The second text develops the imagery; and Tertullian takes it over, elaborating it in turn in his own literal-minded and logical way. If induere is very strongly under biblical influence, superinduere is wholly so. After briefly touching upon 1 Cor. 15.53 (adu. Marc. 5. 10.14), Tertullian joins 2 Cor. 5. 2-4 to the earlier text in a quite natural way:

..siquidem et despoliati non inueniemur nudi - id est : recipiemus quod despoliati sumus, id est corpus, et rursus: etenim qui sumus in isto tabernaculo corporis ingemimus, quod grauemur nolentes exui, sed superindui.

carnem induete. See also Rantero Cantalamessa, La Cristologia di Tettulliano (Paradosis 18), Friburgo, 1962, p. 75-78.

1 See: RenÉ Braun, Deus Christianorum, p. 310-313. It will be remembered that $P$ s. 8.6, interpreted through Hebrews 2. 6-9 also plays an important role in the Incarnational formulations of Tertullian.

2 Some of the places where the formula occurs in an Incarnational sense: adu. Marc. 1.24 .5 ; 3. 7.6 ; 10. 4-5; 4. 11.7; 13.4 ; de cam. $3.4 ; 3.7 ; 4.5 ; 6.13 ; 10.1 ; 11.5-6 ; 16.1$; 16. 4-5; de resurt. 18.6; adu. Prax. 12.3; 27.6. 
2. ..Et illi enim resurgent incorrupti, recepto scilicet corpore et quidem integro, ut ex hoc sint incorrupti, et hi propter temporis ultimum iam momentum et propter merita uexationum antichristi compendium mortis, sed mutati, consequentur, superinduti magis quod de caelo est quam exuti corpus. 3. Et si hi super corpus induent caeleste illud, utique et mortui recipient corpus, super quod et ipsi induant iscorruptelam de caelo...... Illi induunt, cum receperint corpus, isti superinduunt, quia non amiserint corpus... (adu Marc. 5. 12. 1-3).

Tertullian simply takes over the imagery of Paul himself, of course. ${ }^{1}$ What is interesting is how consistently it fits in with his usual imagery complex of clothing, and how vividly he sees the image value of Paul's expressions. A similar comment on, and development of the imagery of Paul is to be found in the de resurrectione, so closely related to the fifth book Against Marcion. Other imagery of Paul - '..habemus domum non manu factam aeternam in caelis..' (2 Cor. 5.1; de resurr. 41.1) - bothers Tertullian, and he would prefer to read this as being concerned with the domicilium mundi, and not as an image of the body (de resurr. 41. 3-4). Tertullian expects that the Bible be as consistent and logical in its imagery as he is with his own. In all events, he goes on to reflect upon 1 Cor. 15. 51-52, and 2 Cor. 5.4, and he explains the imagery which is found there, much as in the adu. Marc. citation just seen:

Sic et cum infulcit: siquidem et exuti non inueniemur nudi, de eis scilicet, qui non in uita nec in carne deprehendentur a die domini, non alias negauit nudos quos praedixit exutos, risi et quia reuestitos uoluit intellegi eadem substantia, qua fuerant spoliati. 13. Vt nudi enim inueniemur carne deposita uel ex parte discissa siue detrita, - et hoc enim nuditas potest dici - (et) dehinc recipient eam, ut reinduti carne $\langle m\rangle$ fieri possint etiam superinduti inmortalitatem: superindui enim nisi uestito iam conuenire non poterit (de resurr. 42. 12-13).

This explanation of Paul's imagery is all the more in its place here, in the de resurrectione, where the complex of clothing imagery, biblically inspired, plays such an important role.

The expression (1 Cor. 15.53), '..indumentum illud incorruptibilitatis..' (de resurr. 36.5; cf. also $56.3 ; 62.3$; ad uxor. 1. 7.1), brings us to another point. The importance of the biblical sources of clothing imagery in Tertullian can be approached from another viewpoint: that of vocabulary. Indumentum, for example, with but two exceptions (de pall. $4.7,5.2$ ), is biblically inspired, and is used in all three moments of imagery: baptism (de pudic. 9.11); Incarnation (adu. Marc. 4. 40.5), and resurrection (texts cited supra). Other examples can be adduced. This is also true of other words used in the context of this imagery; notably of spoliatus, always with a biblical referent, and in function of the three

3 See Straud, op. cit., p. 24-25. 
moments mentioned (de resurr. 42.12; de pudic. 9.11 adu. Iud. 14.7); despoliare is used once in a non-biblical way: '..qui templa despoliant..' (Scap. 2.4); elsewhere it is used, with biblical inspiration, in reference to the resurrection. Superindumentum, a word which Tertullian is the first to employ in Latin, ${ }^{1}$ and which is always associated with the text 2 Cor. 5. 2-4, and the theme of the resurrection (adu. Marc. 3. 24.6; $5.12 .3 ; 12.4$; de resurr. $42.5,9)$. Superinduere is almost always used in Latin generally with reference to 2 Cor. 5. 2-4; the one exception known to the files of the ThLL is found in Suetonius. ${ }^{2}$ Tertullian uses this word also in reference to 1 Cor. 15.53: '. . hanc incorruptibilitatem habemus superinduere ad nouum domin(i)um...' (de cult. fem. 2. 6.4) ${ }^{3}$ This last example is the more interesting, as it occurs in a context occupied with dress and clothing. The allusive superinduere is found in surprising places, always with reference to the resurrection: '..superinduti substantia propria aeternitatis..' (apol. 48.13); '..ubi superindui potius quam despoliari..' (adu. Val. 32.5). ${ }^{4}$ The importance of this constancy of vocabulary must not be exaggerated. Yet it shows how firmly this terminology and this imagery is attached to a given subject in Tertullian.

This brings us the end of a brief study of imagery of clothing in Tertullian. Not without some relation to classical Latin imagery, it is far more deeply biblical in its inspiration, drawing especially on Paul. That logic of Tertullian in the articulation of his images, his literal mindedness, and his ability still to see the image value, even of wellworn words like induere, are here seen again. Through the three moment of its use, there runs a unifying and consistent thread. In this theme also one sees Tertullian reflecting on the special value of biblical imagery; and certain words, for some of which Tertullian is the first witness in Latin, are almost exclusively employed in the field of these images.

\section{Medicine}

Medicine, Tertullian tells us, is the soror philosophiae (de anim. 2.6) ${ }^{5}$, and, throughout the de anima, he makes constant appeal to the teaching of

1 Interestingly, Irenaeus latinus uses the word in a different connotation, adu. haer. proem. 2: '..ignorantes eos propter exlerius ouilis pellis superindumentum..', referring to Matth. 7.15.

a Suetonius, Nero 48.

- See: H. Rónsch, Itala und Vulgata, p. 200. The CG index cites 2 Cor. 5.2 here; but

1 Cor. 15.53 is also present.

- In addition to the texts cited and referred to above, superinduere, with reference to the resurrection, occurs in the following texts also: de resurr. $41.5(2 \times) ; 42.2(2 \times)$; 42.3.

- See comment of J. H. Waszink, De Anima, ad de anim. 2.6, p. 111-112. 
the medici, and comments upon them. Throughout his works, he likes to use medicine and its practice as points of comparison (ad nat. 2. 5.10; apol. 22.11, etc.); he describes an instrument of the physician (inter arma medicorum, de anim. 24.5), and notes how instruments are essential to his practice (adu. Marc. 2. 16.1-2). Of his familiarity with medicine, there is no doubt. ${ }^{1}$

What interests us here, however, is his use of medicine as a theme of imagery, in relation to the situation of the believer and to what extent this theme has relations with the Bible. He describes heresy as a kind of fever (de praescr. 2. 1-8); Marcion's difficulties with the problem of good and evil are a kind of illness from which he suffered (adu. Marc. 1. 2.2); sin itself, as we will see more fully, is a illness.

The remark from the de anima, supra, tells us something of the important place which medicine held. It also supplies examples and points of comparison from classical Latin, as we will note later, especially for the medicus theme itself. The axis of medical imagery in Tertullian is best approached from an analysis of some of his works, where medical imagery plays an important role. Like Christian writers from Ignatius of Antioch ${ }^{2}$ on, Tertullian makes considerable use of 1 t.

In the de baptismo, we find the waters of baptism described as 'medicinal' (de bapt. 4.5); this is also ascribed to water by pagan religions, but the water of baptism has the power of God: 'Si religione aquas medicari putant, quae potior religio quam dei uini agnitio?' (5.2). These medicinal properties find therr model in the pool at Bethsaida, (Joh. 5.2), which was the exemplum futuri: 'Figura ista medicinae corporalis spiritalem medicinam praedicabat, ex forma qua semper carnalia in figura(m) spiritalium antecedunt.' (5.5). An interesting parallel to this is the discussion in de anim. 50. 3-4, of various wonder working waters; the context is very different, but, as usual in the de anima, there is a biblical parallel at hand, and it is the '..lacus medicus..' of Bethsaida. (de anim. 50.3); the adu. Iudaeos cites the pool again for its medicinal qualities (13.26). The implicit comparison in the de baptismo, of course, is $\sin =$ disease. And so, there were waters in the Old Testament, too, which prefigured those of baptssm, with

1 See: Pierre de Labriolle, La physiologie dans l'oeute de Tettullien, in: Archives générales de médicine 83 (1906), 1317-1328.

2 Ignatius of Antioch calls Christ the one Physician: El $I_{\zeta}$ latgós Ėot Adolf Harnack, Medicinisches aus der ältesten Kirche, (Texte und Untersuchungen VIII. 4), Leipzig, 1892; J. OTT, Die Bezeichnung Christi als iat@ós in der urchristlichen Literatur, Der Katholik 90 (1910), p. 454-458; Rudolph Argesmann, The Concept of 'Christus Medicus' in St. Augustine, Traditio 10 (1954), p. 1-28; Christus medicus humilis in St. Augustine, Augustinus Magister (Congrè international Augustinien, 1954), Paris, 1954, Vol. II, p. 623-629; P. C. J. Eijkengoom, Het Christus-medicusmotief in de Preken van sint Augustinus, Assen, 1960. 
their medicinal properties: 'Lignum illud erat Christus uenenatae et amarae retro uenas in saluberrimam aquam, baptismi scilicet, ex sese remedians.' (de bapt. 9.2). We will have occasion to return to the de baptismo for a possible play of words. The use made of medical imagery is simple enough here; and all the images find their justification in biblical texts.

The de patientia has a few texts which interest us. In the opening lines, we come upon an extended figure: those who are ill, says Tertullian, never tire of singing the praises of health (1.4), and he is ill: 'Ita..eo semper aeger caloribus inpatientiae, quam non optineo patientiae sanitatem...in meae inbecillitatis contemplatione digero bonam fidei ualetudinem et dominicae disciplinae sanitatem non facile cuiquam nisi patientia adsideat prouenire.' (1.5). Later, we come the on suggestive comparison: God stands guarantee for patience. For the injury deposited with him, he is the avenger; for loss, the restorer; 'si dolorem, medicus est.' (15.1).

In the de paenitentia, again, we find the implied comparison, sickness with sin. The dose is to be repeated, as the illness returns (7.13); the man reluctant to embrace penitence is like a man who avoids the doctor, whether from shame (10.1), or from fear of the pain which he inflicts (10.10). ${ }^{1}$

It is the aduersus Marcionem, however, which will occupy us longer. Medical language takes an important place in the work, especially in the fourth book, the commentary on Luke. There are complex reasons for this. In the first place, we may mention the biblical texts which Tertullian seems to have taken over from his adversary (cf. supra, p. 8); the antinomy between the God of the world and the Law, and the God whom Christ reveals was suggested by Marcion in that text (Luc. 6. 43-44). To suggest antinornies within the Old Testament itself, and improvidence on the part of the Greator, Marcion seems to have used texts which appear conflated together in Tertullian: Deut. 32.39, and Is. 45.7. They are explicitly ascribed by Tertullian to the antitheses of Marcion: 'Quid antithesís exemplorum distorques aduersus creatorem, quas in ipsis quoque serwibus et adfectionibus eius potes recognoscere? Ego, inquit, occidam et ego reuiuificabo, condens scilicet mala et faciens pacem.' (adu. Marc. 4. 1.10). Tertullian turns the text back upon Marcion; but the two texts appear throughout the controversy with Marcion, ${ }^{2}$ and seem to go back to his own use of them. The Deut. 32.39 text, '..percutiens sed et sanans..' (adu. Marc. 2. 14.1) is the first biblical text which supplics a strand of medical terminology in the polemic. It is one of several

1 Cf. the parallels on those who would avoid the doctor; Seneca, de ben. 6. 36.2; Quintilian, de inst. or. 4. 5.5.

2 Cf., for example : adu. Marc. 3. 24.1; 4. 1.10; 5. 11.4; de fug. 3.1 ; de pudic. 2.4 . 
which might have suggested to Tertullian the figure of God and/or Christ as medicus; a figure which, while present, is not really developed. Tertullian compares the God of Marcion to a doctor who delays the cure of his patient, in order to make it seem more spectacular, and therefore to be more profitable for him (adu. Marc. I. 22.9). Very different is the God in whom Tertullian believes; in a comparison which is rich in possibilities, and which is typical of the subtle language of Tertullian, we find another use of the doctor image, and an interesting play on words: 'Qui credimus deum etiam in terris egisse et humani habitus humilitatem suscepisse ex causa humanae salutis, longe sumus a sententia eorum, qui nolunt deum curare quicquam.' (adu. Marc. 2. 16.3). The preceding context uses the comparison of a doctor; and we may see here a play on the word curare: a medical sense, and then it is read, with '...humanae salutis' as an image of Christ's activity on earth; and in the sense of the Epicurean view of God: that he has no concern with the world. This reading is made extremely probable by the constant occupation of Tertullian with Epicurus and his gods, ${ }^{1}$ and especially by remarks in the adu. Marcionem itself. Earlier, Tertullian had said: 'Si aliquem de Epicuri schola deum adfectauit Christi nomine titulare, et quod beatum et incorruptibile sit neque sibi neque alii molestias praestet - ...ut in totum inmobilem et stupentem deum concepisse debuerat - ...' (adu. Marc. 1. 25.3). And when we find Epicurus mentioned in the lines just before our citation, (2. 16.2), it becomes virtually certain that this play on curare is intended. We have anticipated a later discussion on word plays, in and about salus.

If the comparisons here are not biblically inspired, we return to a biblical base with the text Is. 53.4, which promises Christ - as Tertullian will interpret the text - as medicator:

..docentes praedicatorem interim adnuntiari Christum per Esaiam: quis enim, inquit, in uobis, qui deum metuit, (et) exaudiat uocem filii eius? Item medicatorem : ipse enim, inquit, imbecillitates nostras abstulit et languores portauit. (adu. Marc. 3. 17.5, quoting Is. 50.10, and then Is. 53.4) This is the only time that we find the unusual medicator in Tertullian, and he is the first to use the word in Latin. He returns to the Isaias text in the fourth book; 'Ipse igitur est Christus Esaiae, remediator ualetudinum: hic, inquit, imbecillitates nostras aufert et langores portat.' (adu. Marc. 4. 8.4); '..remediatore languorum et uitiorum adnuntiato Christo..' (adu. Marc.

1 The texts which show Tertullian's preoccupation with Epicurus are too numerous to list. Other adu. Marc. texts: $1.25 .3 ; 25.5 ; 4.15 .2 ; 5.19 .7$. The Epicurean view of the unconcerned God is particularly distasteful to Tertullian: '..otiosum et inercitatum, et, ut ita dixerim, neminem rebus humanis...' (apol. 47.6; // ad nat. 2. 2.8). 
4. 35.5). Here, as in the case of medicator, another curious word is used by Tertullian : remediator. ${ }^{1}$

Now what is interesting is the use that Tertullian makes of this text in the fourth book. The commentary which he makes on Marcion-Luke intends to set up his own antitheses (see, e.g., 4. 24.4), which would attach Christ to, and not separate him from the Old Testament; antitheses which would then be valid for the Marcionite Christ. It is a remarkable fact that a great deal of attention is given to the miracles of healing performed by the Christ whom Marcion proffers. This is, in fact, a chief line which Tertullian follows through Marcion-Luke; ${ }^{2}$ and so, from 4. 8.4 to 36.10 , we find a great many words having to do with healing and sickness. Tertullian roots this activity in the Old Testament, along the lines set forth by the text from Isaias 53.4, as well as by other texts. Such words as: curare, curatio, medicina, medicus, remediare, remedium, ualetudo, etc., are used of real cures performed by Christ, and how they are predicted by the Old Testament. When Christ heals, then we recognise in him the Christ of Is. 53.4; he confers the '..beneficia medicinarum..'(4. 8.4); to free from devils is to cure: '..et a daemoniis liberare curatio est ualetudinum.' (4.8.5). The particularities of the medicina used has all been foreseen (4.10.1-2; cf. 12.15; 24.12; 26.10). The text from Luc. 5.31, '..medicum sanis non esse necessarium, sed male habentibus.' (4.11.1) leads Tertullian to the formulation, medicum Christum (4. 11.3).

But this is not developed in the direction of an image. The accent is on continuity with the Old Testament; of the reality which was promised. Tertullian generally neglects the opportunities which are at hand to develop medical imagery with relation to Christ and God, to elaborate this as significant of rescue from sin. This is particularly true of the fourth book. The reason for this is not far to seek. Tertullian makes but a limited appeal to allegory in the polemic with Marcion; and so he accents the physical reality of the cures. All the material ${ }^{3}$ lies at hand for an expansion on the theme of Christus medicus; but Tertullian has other concerns. He exercises a control over his imagination; here,

1 On remediator, as also on medicator, see: RENE Braun, Deus Christianorum, p. 522.

2 The older idea that Luke shows a peculiar familiarity with medical terminology, is now generally abandoned by exegetes, following the work of HenRY J. CADBuRY; see, e.g., his The Making of Luke-Acts, New York, 1928; reprinted, London 1958, p. 118-119, 219, 273, resuming his earlier work. It remains interesting, however that Tertullian should have chosen this path through Luke.

- Luc. 10.30-37, the story of the good Samaritan does not seem to have been in Marcion-Luke; in any event, Tertullian never comments on it. Augustine will find in the Samaritan another occasion for developing the medicus figure: see R. ARbesManN, Traditio, p. 25, and note 1 ibid. 
absence of imagery is as significant as is its presence elsewhere.

In the scorpiace, we will have occasion to see the medicus figure again. First of all, however, it must be noted that medical imagery forms the basis for this little treatise. The Gnostics and the Valentinians are the scorpions who emerge when it is warn, in the heat of persecution; their deadly sting is the argument that martyrdom is unnecessary. That fullness and elaboration of imagery which we have seen in Tertullian is well exemplified here. The results of the Gnostic argumentation is that of a deadly sting: '..statim omnes pristini sensus retorpescunt, sanguis animi gelascit, caro spiritus exolescit, nausea nominis inacrescit.' (1.10). Following the example of Nicande $i$ - who wrote a 'real' medical treatise, offering antidotes for deadly stings - Tertullian offers an antidote against these argument-stings: '..aduersus nostrates bestiolas nostratem mederi theriacam stilo temperare. Qui legeris, biberis. Nec amarum potio.' (1.12). Now Tertullian is logical, and does not forget his figure; he returns, in the closing words of the scorpiace, to the model on which he built his tract: 'Sed et nunc audire debebit, quatenus multo post uenena ista suffudit, nulli infirmorum facile nocitura, nisi si qui non hanc nostram ex fide praebiberit uel etiam superbiberit potionem.' (15.7).

Within the framework of the treatise, built on the model of the saving potion, we come upon a second complex of medical images, distenct from the elaborate metaphor which forms its basis. The problem which introduces this second axis of imagery is this: how is God, who must be supposed to be good, capable of demanding the death of martyrdom? God's will must be thought to demand what is good, says Tertullian (5. 1-2); and what he clearly wills is good, as what he forbids must be evil. He forbids idolatry. The opposition between martyrdom and idolatry is that between life and death (5.4). He who leads a bad life is really dead: 'Est et haec peruersitas hominum salutaria excutere, exitiosa suscipere, periculosa conquirere, medicamina deuitare, aut mori denique citius quam curari desiderare.' (5.5). This is capable of being read on two levels; that of the medical, and that of the salvific; and this language permits Tertullian to use the comparison of medicine. Those who are stupid, or who have a misplaced modesty, avoid medicine (de paenit. 10.1, 10); the means medicine uses are, of necessity, painful (adu. Marc. 2. 16.1-2), but the patient is grateful, afterwards (de paenit. 10.10), and so it is with martyrdom (scorp. 5.6-7). 'Sic et martyria desaeuiunt, sed in salutem. Licebit et deo in uitam aeternam, per ignes et gladios et acerba quaeque curare.' (5.7). And here we come to the prolonged figure of God as physician. He uses 'homotropic' means of healing (5. 8-9). As with the means which a doctor uses, so is it with the means of God: 
'Peruersitas, quam putas, ratio est; quod saevitiam, existimas, gratia est' (5.10). Tertullian uses a familiar phrase: '....gemens et mugiens inter manus medici..' (5.7); and then, typically, plays on the meaning of a word in another formulation: '..ircidisti in manus eius, sed feliciter incidisti. Incidit et ille in aegritudines tuas.' (5.10). ${ }^{1}$ The entire comparison is prolonged, and sustained; Adam's sin was to eat of the tree, which '..ipse medicus inportunam interim nouerat.' (5.11).

Here, then, we do find a figure of God as the physician. Comparisons drawn from the doctor and his art were commonplaces in Latin literature. Cicero frequently uses them ${ }^{2}$; Seneca, also; we find texts which are like those of Tertullian: the sick man does not like the means which the doctor uses, ${ }^{3}$ and to fall into the hands of the doctor seems to have been a well worn phrase. ${ }^{4}$ As is well known, the image of the physician was very soon taken over by Christian writers, ${ }^{6}$ and the figure is highly developed in Augustine. ${ }^{\circ}$ Here Tertullian is very much the heir of his Latin predecessors, to say nothing of other possible sources.

Chapter five of the scorpiace, then, is a prolonged comparison, which is sustained with that logic of Tertullian. It affords him the opportunity to play on life and death, on sickness and health; and, while this whole axis remains separate from the model of the treatise, Tertullian is, nevertheless, able to bring it back to the original theme of the work:

Sed dominus sustentata feruura delicti, donec tempore medicina temperaretur, paulatim remedia composuit, omnes fidei disciplinas et ipsas aemulas uitio, uerbum mortis uerbo uitae rescindentes, auditum transgressionis auditu deuotionis limantes. Ita, et cum mori praecipit medicus ille, ueternum mortis excludit. 13. Quid grauatur nunc pati homo ex remedio quod non est tunc grauatus pati ex

1 On the expression, incidere in manus medici, see P. C. J. Eujkengoom, Het Christusmedicusmotief, p. 71. The play on words which Tertullian uses in the citation above is illustrated by passages from Cicero: one the one hand, to fall into the hands of (incidere in manus), as in pro Scaur. 3: '..ne in manus incideret..'; pro Caecin. 45: '.. in manus eorum incidere..'; and, on the other, to fall into illness: de senect. 67: '.. facilius in morbos incidurt adulescentes..'.

Q Cf., e.g. de fin. 5.7; Tusc. 3.23; 3.82; de nat. deor. 3.76; 3.78.

- Cf. Seneca, ep. 59.9; 52.9: ‘. .numquid aeger laudat medicum secantem?"

' ibid., 75.6: '..non tamen erit, quare gratuletur sibi, quod inciderit in medicum etiam disertum..' and cf. EijKenBoom, op. cit., p. 71.

s The best overview remains: Adolf Harnack, Medicinisches aus der älesten Kirche, (TU VIII.4), Leipzig, 1892.

- R. Arbesmann, in Traditio 10 (1954), p. I-28, emphasizes the aspect of medicus humilis; see p. 10-11; it is interesting that this is suggested by Tertullian, also, in adu. Marc. 2. 16.3 (text cited, supra, p. 101). P. C. J. Eijкenвoom, in Het Christusmedicusmotief, tracing the motifs in the sermones, broadens the value of the medicus theme to include patience, humility, and love; see p. 219-220. 
uitio? Displicet occidi in salutem cui non displicuit occidi in perditionem? Nausiabit ad anitidotum qui hiauit ad uenenum? (5.12-13).

This, therefore, is the most sustained development of the figure of God as physician which we find in Tertullian. It departs from classical commonplaces, and is applied to the Christian situation; despite biblical accomodations, the theme remains non-biblical in its inspiration.

In the de ieiurio, we find an interesting parallel to the last citation from the scorpiace. Medical terminology is used here again; the sin of Adam concerned eating; the antidote is fasting, where the poison was food:

Ostendens tamen, unde sit occisus Adam, mihi reliquerat intellegenda remedia offensae, qui offensam demonstrarat. Ultro cibum, quibus modis quibusdam temporibus potuissem, pro ueneno depularem et antidotem famem sumerem, per quam purgarem mortis a primordio causam in me... (de ieiun. 3.3 ).

If Tertullian had used several stock examples from medicine in his earlier work, de paenitentia, underlying which constantly runs the comparison sin = sickness, in the de pudicitia we find a different use of this imagery. Christ came, indeed, '...medicus languentibus magis quam sanis necessarius...' (de pudic. 9.12). But there the illness is placed elsewhere. '..quis labat de ualetudine, hisi qui Deum nescit? Quis saluus ac sanus, nisi qui Deum nouit? (9.13). Those who are ill, whose whom Christ came to cure, are not the labile sinners, globally taken, but those who do not know God. The figure of Christ as medicus for sinners is avoided by Tertullian, for it suggests a constant recourse to that cure, a constant re-taking of the medicine, as it should prove necessary (contrast this with the idea of de paenit. 7.13: '..iterandae ualitudinis iteranda medicina est.'). In the rigoristic de pudicitia, the figure of Christ as medicus for sinners is not to Tertullian's purpose. He criticises the idea that the martyres have special powers of intercession, to obtain the forgiveness of the sins of others. They themselves are frail, and they may be glad if their sufferings have obtained their own release. Tertullian expresses this frailty in a suggestive use of the medicus personage: 'Quis enim in terris et in carne sine culpa? Quis martyr saeculi incola, denariis supplex, medico obnoxius et fenatori?' (22.3). Here, the medicus becomes the sign of the frailty of the martyr himself; but it is not the salvific medicus that is meant.

It is now clear why a synthetic view of medical imagery in Tertullian, which would run through all his works with a relatively stable value, is not possible. Depending on his polemical needs, the figure etther appeats, or is conspicuously absent; it takes on different values. 
A synthetic view can be presented from the point of view of certain word plays which Tertullian makes on saluus, sanus, salus, curare. ${ }^{1}$ Some of these word plays have already been noted.

Saluus is so connected with human salvation, that Tertullian, defending a tortured exegesis of 1 Cor. 5.5, has to gloss the term: 'Superest igitur ut eum spiritum dixerit, qui in ecclesia censetur, saluum id est integrum praestandum in die Domini ab immunditiarum contagione..' (de pudic. 13.25). A play on words centered about salus and curare has already been seen (adu. Marc. 2. 16.3, supra, p. 101; cf. scorp. 5.7). Taking the principal Old Testament prediction of Christ as healer, Tertullian seems to suggest a play on the meanings of salus: '...ut livore eius sanaremur, ut dedecore eius salus nostra constaret' (adu. Marc. 4. 21.12). The first member is formed by the citation from Is. 53.5, the second an explicitation by Tertullian: sanaremur brought into accord with salus. Similarly in de paenit. 12.5: '..cur salutem tuam deseris, cur cessas adgredi quod scias mederi tibi?' The play on words depends on the constant subjacent metaphor, sin $=$ sickness. Tertullian spells out this relation when, in the de baptismo, he explains the relation of the waters of Bethsaida, and those of Baptism: '..qui uitia corporis remediabant nunc spiritum medentur, qui temporalem operabantur salutem nunc aeternam reformant..' (de bapt. 5.6). The pisciculi remain salui by remaining in the water (de bapt. 3.1), and here again, the value of saluus, healthy, saved, is played upon. Other instances of such word plays might be adduced. They are in function of the symbolism of health and sickness, symbolic of salvation and sin. This relation makes the medicus motif, and imagery from medicine, so attractive for Christian writurs. It remains true, however, that the medicus figure is developed of God only in the fifth chapter of the scorpiace; a development which is in accord with the web of medical imagery which lies at the basis of the tract itself, though independent of it. In this treatise, the logical mind of Tertullian, even in his imagery, is clearly seen. While Christ is identified in the aduersus Marcionem as the medicus, medicator, remediator, this is in function of the fulfillment of Old Testament prophecies, notably of Is. 53.3. It is not a figurative use. Tertullian intends to show that the Christ of the Marcionite Luke is in fact a healer. Marcion himself had portrayed Christ as the spiritus salutaris, ${ }^{2}$ himself scarcely embodied, and intent upon a spiritual salva-

1 See: Christine Mohrmann, Das Wortspiel in den Augustinischen Sermones, Mnemosyne III.3 (1932), p. 33-61 (= ELC ${ }^{2}$ I, p. 323-349; p. 331); P. C. J. EiJkenBoom, op. cit., passim; ReNE Braun, Deus Christianorum, on salus: p. 478-483; saluus: p. $490-495$.

2 adu. Marc. 1. 19.2. See A. von Harnack, Marcion ${ }^{2}$, p. 123. Rent Braun approaches this question from another point of view. In his Detus Christianonum, p. 494-495, he 
tion; wholly new, standing over against the Old Testament and its God. Tertullian has to prove that he is in continuity with the Old Testament, and he does this by selecting, as one of his chief threads through Marcion-Luke, the species curationum (adu. Marc. 4. 8.4; cf. 4. 35.5); these cures are really performed, on real men. The figurative use of the Christus medicus theme is not possible here, because of the exigencies of the argument. Tertullian, taking to allegory in the adu. Marc. only when he has to, and when the text of Marcion permits him, is far better served by not following a figurative development of this theme in his polemic with Marcion.

Curiously, it is precisely in the adu. Marc. that the Christus medicus figure is best rooted in Scripture. When, as in the scorpiace, and elsewhere, he uses the medicus figure of God, and medical imagery, he is much more in continuity with commonplaces of classical Latin literature. In the de baptismo, the medical power of water, and the imagery resultant, is biblically oriented, just as water itself is primarily biblical in Tertullian's imaged use of it. All the material is here for a development of medical imagery, and the Deus/Christus medicus motif, such as we find it developed in Augustine ${ }^{1}$; in Tertullian, it is sketched, but is not central.

\section{Arms ANd Athletics}

Here we come to one of the best known theme of imagery in Tertullian, one also which affords him opportunity for many word plays. Because imagery from arms shades into that taken from gladiatorial combat, and this, in turn leads into athletic figures, they will be treated under this one heading; but each has its own value in Tertullian, and to this extent, must be treated separately. It is, doubtless, a mistake to attempt to root the frequent military language of Tertullian in the autobiographical note of apol. 9.2: '...militia patris nostri.' Here again, Tertullian follows a tradition of commonplaces in Latin, and this tradition meets with a Christian theme of military language. ${ }^{2}$

suggests that the relative rarity of the words saluator ( $3 \times$ in Tertullian), and the neologism salutificalor ( $6 \times$ in T.), and periphrastic phrasings with salus $(3 \times)$ in Tertullian is due to the fact that they were pre-empted by various sects, and by the Marcionites in particular. This is an important aspect to the imagery of medicator; and, though Tertullian may wax indignant against the cult of Asclepius (ad nat. 2. 14.4 ff.), he ignores - carefully, it may be - all religious aspects of the theme.

1 Cf. R. Armesmann, Traditio 10 (1954), p. 1-28; P. C. J. Etjkendoom, Het Christusmedicusmolief, passim.

2 On the predilection of Christian authors for this language, see: Adolf Harnack, Militia Christi, Tubingen, 1905, texts, p. 93-114; Christine Mohrmann, La langue de Saint Benott, in: Sancti Benedicti Regula Monachorum, Maredsous, 1955 (= ELC II, 325-345; p. 33 -340). 
controversy as combat We may begin with an axis of imagery which is relatively little noticed. Running as a constant through the controversial works of Tertullian, we find many 'violent' words, sometimes from military parlance, sometimes from gladiatorial combat - the distinction is not always easy to make - which lend an immediacy to his polemic. A series of texts will make this clear; then some words will be examined, to show how, generally, they fit into a Latin tradition.

His proluserim quasi de gradu primo adhuc et quasi de longinquo. Sed exhinc iam ad certum et comminus dimicaturus, uideo aliquas etiamnunc lineas praeducendas, ad quas erit dimicandum, ad scripturas scilicet creatoris (adu. Marc. 3. 5.1).

..ut quod aduersarii in prima statim acie obstruunt, in ultima congressione prosterneremus, omnibus quaestionibus quasi auxiliis eius ante disiectis (de resurr. 48.1).

..nos autem de deo alibi dimicantes et de reliquo corpore haereticae cuiusque doctrinae nur.c in unam speciem congressionis certas producimus lineas.. (scorp. 4.3).

.. ad hanc iam lineam dimicabit nostra congressio.. (de pudic. 6.1).

It is not difficult to multiply instances of comparable texts. They are especially numerous in the aduersus Marcionem. Looking at some of the words which make up this line of imagery:

acies: itself a metaphor, from the cutting edge of an instrument, applied to a military front, or line, Tertullian speaks also of the '..apostolicam aciem..' (de pudic. 17.1). That this was normal language, when speaking of judicial disputes and the like, appears from instances in Cicero' ${ }^{1}$, and Livy. ${ }^{2}$ In most instances acies, as the other language illustrating controversy as combat, is in a direct line with ordinary, Latin usage. But, as in de fug. 11.2: '.. ad gradum in acie figendum..', we can find it applied to the Christian combat; here, standing firm in persecution. Later Christian writers will use acies of this Christian combat. ${ }^{\mathrm{s}}$ comminus: as seen in adu. Marc. 3.5.1, (text quoted on preceding page), this image of hand-to-hand combat occurs about five times in an imaged way in Tertullian. Here again, he is taking over language of disputation. 4

congredi : frequent in Tertullian, this word can also shade into the Chris-

1 Cicero, Scaur. 20: '..non est unus mihi quisque ex illorum acie protrahendus..' ‘..tota est acies illa..prosternanda..'

${ }^{2}$ Livy, 6. 15.3: '(Manlius) ..ad tribunal uenit. Hine senatus hinc plebs surm quisque intuentes ducem uelut in acie..'

See: ThLL I, col. 412 .

- Cicero, de diu. 2. 26: '..nunc comminus experiamurque...cornua commouere disputationis tuac..'. 
tian combat, as in ad mart. 1.4. Usually, however, it is used of controversy, and this again, is traditional. ${ }^{1}$

congressio: very generally, congressio represents a hostile meeting, congressus a more neutral one. But this is not always the case: in adu. Marc. 4. 1.2 congressus is used in the hostile sense. ${ }^{2}$ Tertullian himself seems conscious of the possible ambiguity of congressio, as appears from de idol. 21.2: '. . amica aut inimica congressione..'

cuneus : here, Tertullian seems original, or nearly so. The division made in the ThLL of the uses of Tertullian's cuneus are difficult to follow, given the fact that it always seems to be used with a more or less imaged sense, and in the context of controversy. ${ }^{3}$

dimicare: a traditional image for judicial controversy ${ }^{4}$, this also can shade into the area of Christian combat, as in adu. Marc. 3. 18.6; 4.20.4. Generally, it takes its place, however, in the controversial language of Tertullian. ${ }^{5}$

gradus: used in combinations like: gradum figere, conserere, colligere, etc., gradus seems to be taken from gladiatorial combat; Cicero and Seneca used it of the 'position' of the soul ${ }^{6}$; Quintilian ${ }^{7}$ of argumentation. Tertullian favors the word, in the sense of a position taken in combat with an adversary. ${ }^{8}$ In much the same way, he uses linea. ${ }^{9}$

This brief, and schematic presentation may be enough to outline this axis of imagery in Tertullian. To say that it is found in the controversial works of Tertullian is not overly helpful, as Tertullian is so frequently the polemicist; here again, however, we see how Tertullian is capable of still seeing the image value of well-worn words, and of elaborating imagery about them in a logical way; and that this language generally serves a given function.

arms, and military life Here we move into an area which is quite well

2 ThLL IV, col. 287.

ThLL IV, col. 297; 294. Tertullian appears here to be original.

s ThLL IV, col. 1405: the usages de resurr. 2.11 ; adu. Val. 3.5 , distinguishing these from adu. Marc. 1. 21.6, under the heading in imagine (col. 1404), as also de pudic. 5.9. But the uses are equally figurative in their use. Tertullian is here relatively original in his imaged use of cuneus.

4 ThLL V, 1.1, col. 1201 ; Cicero, pro Sest. 1 : ‘..reos pro capite dimicantes; Petron., sat. 13.4: '..plane iure ciuili dimicandum..'

- See also: adu. Marc. I. $1.7 ; 7.7 ; 3.5 .1 ; 5.1 .8$; de anim. $1.1 ; 32.8$.

- ThLL VI, 2 fasc. xi, col. 2145; Cicero, de off. 1. 80 : “. fortis.. animi..est non perturbari in rebus asperis nec tumultuantem de gradu..deici.' Seneca, dial. 2. 19.2: ', .non deiectus, ne motus quidem gradu..'

' Quintilian, de inst. or. 5. 7.11 '..uelut in gradu reponantur..'

8 de praescr. 9.1; adu. Marc. 1. 9.2; 13.1; 3. 2.1; 5.1; 4.2.3; 6.1; 9.14; 29.5; 29.16; $37.2 ; 5.1 .8 ; 10.2 ; 16.6$; de anim. $26.1 ;$ scorp. 8.1 ; de ieiun. $11.4 ; 13.1$; de uirg. uel. 11.1; de pudic. $7.13 ; 21.1 ;$ adu. Iud. $2.1 ; 7.1$, etc.

- adu. Marc. 1. 9.2;3. 5.1; 5. 1.8; de anim. 26.1; de carn. 17. scorp. 4.3; de pudic. 6.1, etc. 
known, and needs no further insistence. Words like castra were used by Cicero ${ }^{1}$ of political parties, and philosophical schools, as Horace speaks of seeking out the "..nil cupientium castra." In the same line of imagery, Tertullian speaks of the castra ecclesiae (de pudic. 14.17). To leave the Church and its discipline means to join the castris rebellium (de praescr. 41.7 ; cf. also the texts de spect. 24.4 ; de paenit. 6.7 , where what seems a simple example is much more significant in the context of this imagery's importance in Tertullian); Tertullian devotes the 1lth chapter of the de corona to an ingenious play on images which find a military and Christian resonance: sacramentum $^{3}$, gladius, statio $^{4}$, pilum, uexillum, signum, tuba, all are at once Christian and military (de coron. 11.1.-5). Typical of how Tertullian elaborates on imagery which the nature of his subject matter presents, and how this imagery permits him to play on words, - we may note, for example, the sentence: 'Ipsum de castris lucis in castra tenebrarum nomen deferre tratsgressionis est' (de coron. 11.4), where not only nomen deferre, but also transgressio plays on two values of the expression this chapter culminates in the famous, and difficult: 'Apud hurc tam miles est paganus fidelis, quam paganus est miles fidelis.'

miles and militia: the example of the soldier is very frequent. The implicit comparison of the Christian to a soldier, sometimes with 2 Tim. 2.3 behind ${ }^{i t},{ }^{\circ}$ is a favorite one of Tertullian. Sometimes simply used, but with pregnant meaning, as in de praescr. 12.2; de paenit. 6.7; sometimes drawing a parallel between the soldier and Mithra, the Christian and Christ (de praescr. 40.4; de coron. 15.3); the flesh is represented as the testimonii sui miles (de resurr. 9.2); miles appears frequently in Ter-

1 Cicero, pro Caecin. 29.83; ad fam. 9. 20.1.

2 Horace, carm. 3. 16.23.

- On this difficult word see: E. DE BAcker, Sactamentum, le mot et l'idée dans Tertullien, Louvain, 1911; J. De Ghellinck el al., Pour l'histoire du mot "sacramentum" (Spicilegium sacrum Lovaniense 3), Louvain, 1924, I: Les anténicéens; AdolF KolPING, Sacramentum Tertullianeum, Münster, 1948, p. 77-95; Christine Mohrmann, Sactamentum dans les plus anciens textes chretiens, The Harvard Theological Review 47 (1954), 141-152 (= ELC I, p. 233-244), and other literature there cited; Tomas BuRgos, Concepto de "sacramentum" en Tertuliano, Helmantica 10 (1959), p. 227-256; RENÉ Braun, Deus Christianorum, Paris, 1962, p. 435-443.

- On statio, see: Christine Mohrmann, Statio, VG 7 (1953), p. 221-245 (= ELC III, p. 307-330), and the literature there cited.

s On paganus, and the passage de coron. 11.5, see: Berthold Altaner, Paganzs. Eine bedeutungsgeschichtliche Untersuchung, Zeitschrift für Kirchengeschichte 58 (1939), p. 130-141 ; Christine Mohrmann, Encore une fois: Paganus, VC 6 (1952), p. 109-121 (= ELC III, P. 279-281); E. Demougeot, "Paganus", Milhra et Tertullien, Studio Patristica, Vol. III (Oxford Patristic Congress, 1959) Texte und Untersuchungen 78, p. 354-365.

- See: de coron. 11.5; de fug. 10.1: '..bonum militem Christo imperatori stw...'; de castit. 12.1 : 'Non enim et nos milites sumus - non et nos peregrinantes - in isto saeculo - sumus....' 
tullian, as in Christian literature. ${ }^{1}$ It is closely related to militia, of course. Not without a biblical base, in the arma militiae nostrae of 2 Cor. 10.4, militia had already been used in a variety of ways by the Latin predecessors of Tertullian. ${ }^{2}$ Tertullian reflects on the use of such language, as in the de orat. 19.5: 'Si statio de militari exemplo nomen accepit (nam et militia Dei sumus)..'; he plays on the words common to both areas; '..militiam Dei uiui iam tunc, cum in sacramenti uerba respondimus' (ad mart. 3.1).

arma: When Tertullian speaks of the arma medicorum (de anim. 25.5), he is using a stock metaphor. But here, we move into an area that is heavily biblical in its inspiration. Tertullian reflects on the meaning of biblical imagery of arms, the arma allegorica of Old Testament prophecy, where Ps. $44.3 \mathrm{ff}$. is the point of departure, whence Tertullian goes on to unite Scripture along the axis of this language (Apoc. 19.21; Eph. 6.12; Matth. 19.29; 10.34: adu. Marc. 3. 14.1-7; 4. 20.4). Prayer is the armament of the Christian: 'Oratio murus est fidei, arma et tela nostra aduersus hostem, qui nos undique obseruat. Itaque numquam inermes incedamus. Die stationis, nocte uigiliae meminerimus. Sub armis orationis signum nostri imperatoris custodiamus, tubam angeli expectemus orantes (de orat. 29.3).

Of all scriptural texts it is Eph. 6. 11-18 which most inspires Tertullian. He once refers to the arma iustitiae of Rom. 6. 12-13 (de resurr. 47.3); but the Ephesians text is more important. Here, it is interesting to note that luctatio always, and luctari with but one exception (ad nat. 2. 11.13), is bound to association with the Eph. 6.12 text. This is a hint of how heavily biblical is the inspiration of his imagery in such places. In some passages (de praescr. 39.1; adu. Marc. 5.18.12) the image is not made specific; in others (de spect. 29.5; de resurr. 22.11; de fug. 1.5; de ieiun. 17.8) luctatio and luctari evoke an athletic/gladiatorial combat. The Christian is totus de apostolo armatus, like the soldier of de coror. 1.3 (cf. also de resurr. 3.4: 'Quid alieno uteris clipeo, si ab apostolo armatus es?'; de fug. 10.1). At least thirteen clear allusions to the text Eph. 6. 11-18 are found in Tertullian, and it is clearly a watershed for this aspect of arms imagery. The entire complex of imagery is intricate; but, as it is well known, it is not necessary to details all its uses in Tertullian. As

1 See: A. Harnack, Militia Christi, Tübingen, 1905; texts, p. 93-114; ThLL VIII. 6, cols. 944-945.

2 Cicero, in Verr. 2. 5.104; Horace, carm. 4. 1.16: '..signa...militiae tuae.. (scl. Veneris; the old scholiasts comment that Horace uses militio 'allegorically' of love); Propertius, 1. 6.30: '..hane me militiam fate subire uolunt...'; and see ThLL VIII. 6, col. 958. The usage in Apuleius, met. 11.15: '..da nomen sanctae huic militiae...', is especially interesting. 
already noted (cf. p. 108, supra), these images move, almost impercestibly, into the area of athletics.

The ad mart. is an excellent example of this transition. In the opening chapters we find military words, and the brilliant figure: 'Nec illi tam bene sit in suo regno, ut uos committat, sed inueniat munitos et concordia armatos: quia pax uestra bellum est illi.' (ad mart. 1.5) ${ }^{1}$. From the militia Dei uiui (3.1) we move, through the image of training, '...ad exercitationem uirtutum animi et corporis..' (3.3), to the imagery of the agon. Tertullian presents and elaborates the picture of the martyr as athlete ${ }^{2}$ :

Bonum agonem subituri estis in quo agonothetes Deus uiuus est, xystarches Spiritus Sanctus, corona aeternitatis, brabium angelicae substantiae, politia in caelis, gloria in saecula saeculorum. 4. Itaque epistates uester Christus Iesus, qui uos Spiritu unxit, et ad hoc scamma produxit... (ad mart. 3. 3-4).

Of the Greek loan words, agonothetes (agonithetes) ${ }^{3}$ is found again in scorp. 6.5, de fug. 1.5, again in contexts of martyrdom; epistates ${ }^{4}$, scamma, xystarches do not again appear in Tertullian. The imagery of the martyr/ athlete is a constant, however. In the ad mart., the prison house of the martyrs is a palaestra, the stadium is to be found before the judge (3.4). How heavily Pauline is the inspiration of the passage cited above, is evident; the bonum agonem reflects 1 Tim. 6.12: the corona aeternitatis suggesting the contrast of earthly and corruptible crowns, 1 Cor. 9.25. Tertullian then moves naturally into exempla ${ }^{5}$, and to the athletic certamina (5.1; cf. apol. 50.7).

In the de spectaculis, the life of the Christian is presented as an athletic struggle. This is natural, in view of the subject matter of the tract, and the frequent mention of the agon throughout it (de spect. $3.2 ; 10.13$; $11.1,2$; etc.). Tertullian turns from the games and asks: 'Vis et pugilatus et luctatus? Praesto sunt, non parua, sed multa. Aspice impudicitiam deiectam a castitate....et tales sunt apud nos agones in quibus ipsi coronamur.' (de spect. 29.6). The devil is a grotesque athlete: 'Et palaestrica diaboli negotium est: primos homines diabolus elisit. Ipse gestus colubrina uis est, tenax ad occu1 See: Christine Mohrmann, Tertullianus: Apologeticum en andere geschriften uit Tertullianus' Voor-Montanistischen tijd (Monumenta Christiana, eerste reeks, deel III) Utrecht en Brussel, 1951; note $a$ ad ad mart. 1. 5, p. 188.

- See: Edward Malone, The Monk and the Martyr (Studies in Christian Antiquity 12, Washington, 1950; H. A. M. Hoppenbrouwers, Recherches sur la terminologie du martyre de Tertullien à Lactance (LCP 15), Nijmegen, 1961, p. 71-73.

a According to Vincenz Burhart, Tertullian-Studien, Osterreichische Akademie der Wissenschaften, Philosophisch-historische Klasse, Sitzungsberichte 231, Band 5, Wien, 1957 , no. 10 , p. 7 , the best mss. have agonithetes.

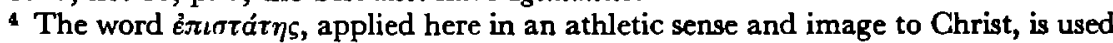
in the New Testament only by Luke, where other evangelists use $\delta_{\imath} \delta$ á $\sigma \kappa a \lambda o s$, etc. See: Lut. $5.5 ; 8.24 ; 8.45 ; 9.33 ; 9.49 ; 17.13$.

- See Hélène PÉtré, L'exemplum chez Tertullien, p. 73-82. 
pandum, tortuosa ad obligandum, liquida ad elabendum.' (de spect. 18.3; cf. adu. Marc. 2. 10.6, where the same idea appears: 'Certamini enim dedit spatium, ut et homo eadem arbitrii libertate elideret inimicum...). The closing chapter, finally, of the de spect. presents the great spectaculum if the aduentus Domini (30.1 and ff.) ${ }^{1}$; similarly, scorp. 6.6. 1 Cor. 9.24 inspires the picture in ad uxor. 1.3.6, where the Christian life is presented as a certamen.

While the imagery is broadened to Christian life, it is the martyr aspect which dominates. Again, we find Tertullian reflecting on the meaning of this imagery, and its source. The sixth chapter of the scorpiace is an implicit comparison of the Christian, the prospective martyr, and the athlete. The origin of the imagery is rooted in Scripture: 'Sed si certaminis nomine deus nobis martyria proposuisset, per quae cum aduersario experiremur, ut, a quo libenter homo elisus est, eum iam constanter elidat..' (scorp. 6.1; cf. again, de spect. 18.3; adu. Marc. 2. 10.6). Parallel to this explanation (cf. also scorp. 6.7), is the more explicit location of such language in the Apocalypse: 'Sic et agonem intellegi capit persecutionem. A quo certamen edicitur, nisi a quo corona et praemia proponuntur? Legis edictum agonis istius in Apocalypsi..' (de fug. 1.5). Here we have come back to language similar to that used in the ad martyras. Tertullian is doubtless

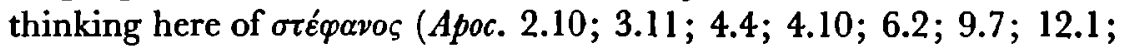

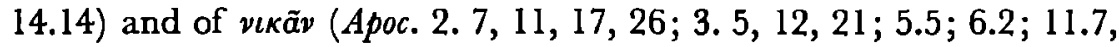
etc.) rather than of $a \gamma \omega \omega v$, which does not occur in the Apocalypse. The athlete: martyr figure, thefore, is a constant. Even the violent language of controversy points this way occasionally.

This familiar axis of imagery shows Tertullian, again, logically elaborating his imaginative language; reflecting on its biblical sourcts; using it for given purposes; of which the primary lines here are to be found in controversy, the Christian life, and the martyr, all presented in language that runs from the violent, through the military, to the athletic. Within the contexts of this imagery, Tertullian is able to indulge his taste for word plays, especially in the language drawn, through tradition, from military life. Here again the crossing of the biblical, and the 'classical' are to be seen.

\section{The Plastic View of Creation}

Here, briefly, two images are to be mentioned; the potter, and the use of plasmare. It is first of all interesting to note that Tertullian, after

1 On this figure in Western literature, see: ERnst Robert Curtrus, European Literature and the Latin Middle Ages (English translation of Europaische Literatur und lateinisches Mittelalter, Bern, 1948), New York, 1953; Harper Torchbook edition, New York, 1963, p. 138-144. 
describing the Stoic view of God and the creation in this imagery, apol. 47.7: '..qui figuli modo extrinsecus torqueat molem hanc..', comes back, and insists that this view of the world and its creation is not limited to the Christians, but has come (through Scripture) even to the pagan world: 'Ipsum certe corpus hoc nostrum, quod de limo figulatum etiam ad fabulas nationum ueritas transmisit..' (de carn. 9.2). ${ }^{1}$ It is interesting to see how literal Tertullian is in his use and interpretation of biblical imagery. The exteriority of the uas image, used by Paul in 1 Thess. 4.4 of man's body, bothers Tertullian; he goes on to speak of Paul's language elsewhere, exterior homo, and claims that this has priority (de resurr. 16.11). For, as he goes on, 'Vas enim (a) capacitatis nomine dicta est, qua animam capit et continet, homo uero de communione naturae quae eam non instrumentum in operationibus praestat, sed ministerium.' (de resurr. 16.12). To this extent, Tertullian distances himself from the Pauline image, and also from an image which we find in Cicero. ${ }^{2}$

After noting these two crossings of the biblical and the classical, one notes the simple examples taken from the potter's craft (ad nat. 1. 12.5-9 // apol. 12.3; adu. Hermog. 19.3, 4; 25.3: since, in the adu. Hermog., the argument is about creation, these examples come naturally here). In the de baptismo, the parallel between creation and working in clay is spelled out in detail (3.5). Apparently, it is the text Rom. 9. 20-21 (Is. 45.9) which impressed itself most on Tertullian: 'Nam et si scriptum est: Numquid argilla dicet figulo? id est homo deo, et si apostolus: In testaceis, ait, uasculis, tamen et argilla homo, quia limus ante, et testa caro, quia ex limo per adflatus diuini uaporem.' (de resurr. 7.5) We find the text in de paenit. 4.3, in a curiously mixed sequence of images, and in $a d u$. Marc. 2. 2.7). Figulus and figulare usually, though not always, deal with the creation; limus is wholly associated in Tertullian with the Genesis 2.7 narrative.

In connection with this, it is interesting to note the words plasmator (adu. Iud. 2.1; 2.2), plasmare (adu. Iud. 13.11) de spect. 23.7), plastica (de spect. 18.2; de cult. fem. 2. 2.6; 5.2)..$^{3}$ Tertullian sees God at work

1 See J. P. Waltzing, Tettullien: Apologétique, Paris, 1931, note ad apol. 47.7, p. 299-300.

' Cicero, Tusc. 1. 22.52: '..corpus quasi uas est, aut aliquod animi receptaculum..'

a Tertullian is the first to use the word plasmator in Latin. Irenaeus latinus uses it also, in adu. haer. 1. 14.7, e.g. Tertullian is also the first to use the verb, plasmare, in Latin.

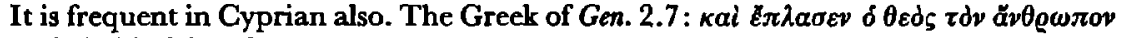
$\ldots$ is behind it, of course.

Augustine has an interesting comment on the terms used in Latin translations for create. A very subtle reading of fingere, he says, make some prefer the translation plasmare: 'Nam quidam interpretes noluerunt dicere finxerunt me sed plasmauerunt me, magis diligentes minus latine declinare de graeco, quam dicere funxerunt, quod aliquando etiam 
with his hands: '..non imperiali uerbo, sed familiari manu..' (adu. Marc. 2. 4.4; cf. the similar texts, de resurr. 6.1, 7.1).

\section{Conclusion}

There are other themes of imagery in Tertullian - light and darkness is an obvious example - but those which have been seen so briefly are the chief ones. Tertullian is a sharp observer of life (note, for example, the frequent images from the baths: adu. Marc. 3. 3.2; de idol. 5.2; de fug. 13.3), and can evoke a scene vividly (de spect. 16. 1-3); of his imaginative powers, there can be no doubt. ${ }^{1}$ Even well-worn words are still seen by him, and he can revive them to freshness. In a sketch, we have seen how two traditions of imagery, classical and biblical, meet in him; the one often passing imperceptibly into the other. In many instances, Tertullian reflects on biblical imagery and on its meaning. To some extent, he feels the importance of this imagery, and its need of explanation.

While Tertullian never limits himself to a single axis of imagery in any one work, we have seen how some works are peculiarly unified by themes of imagery. The most striking example is that of the scorpiace, where the model of the work is taken from the saving potion, and where Tertullian, in his classical manner, begins and ends with this unifying image. The controversial works use that violent language; works having to do with martyrdom, as the ad mart., de idol., de fug., use athletic imagery; the de paenit. is unified, largely, by images of the sea and shipwreck. The de resurr. uses images of seed and clothing: the de coron., military imagery.

While Tertullian is not always felicitous in the choice of his images, he is, nonetheless, remarkably controlled and logical in the elaboration of them. While occupied with an image, he is unified in its development. That development is, for our taste, too full; but it remains logical.

It is the new source, the Bible, which Tertullian draws upon that has lent new life to themes which Tertullian found upon the commonplaces of Latin literature. There is no doubt that the theoretical reader, who did not know the Bible, would miss much of the import of the imagery of Tertullian.

de simulatione dici solet.' This in comment on Ps. 118. 73, in: Enarr. in Psalmos 118, s. xviii. 2 (E. Dekkers and I. Fraipont, CC XL, P. 1724, 1. 14-17).

1 See Paul Monceaux, Histoire littéraize de l'Afrique chrétienne, Paris, 1901, impression anastatique, Bruxelles, 1963, I, p. 452-455; Christine Mohrmann, Tertullianus: Apologeticum en andere geschriften, p. Looxvi-xcv, especially p. xciv-xcv; Observations sur la langue et le style de Tertullien, Nuovo Didaskaleion 4 (1950), p. 41-54 (= ELC II, p. 235-246). 
This chapter is not without its links with the preceding, The Problem of Biblical Language, and with the following, Exegesis and its Vocabulary. We have seen how certain words are wholly, or almost wholly associated with certain biblical texts, and how they evoke these texts. This is a small indication, but a valuable one, and it tends to confirm the view that Tertullian knows his Bible extremely well, and he knows it in Latin. He is so influenced by the imagery of Genesis, Isaias, Psalms, Matthew, Paul, and the Apocalypse that these supply him with important new dimensions for his imagery. It would be curious indeed if this happened only through Greek. Remembering that these texts may not have been wholly translated, the view that Tertullian is steeped in Latin biblical texts is quite probable.

In the reflections which Tertullian made on biblical texts, we have already anticipated the problem of his attitude towards exegesis, and its rules. If, as is well known, he limits the use of allegory severely, we see quite another element in his use of, and his dependence upon, biblical imagery. That it is deeply significant for him is beyond question. When he is not concerned with limiting the portée of a biblical text against an adversary, his interpretation is far more open than his own limiting rules, in the de pudic., would permit. 


\section{EXEGESIS AND ITS VOCABULARY}

\section{INTRODUCTION}

Thus far, we have seen some aspects of biblical language and imagery in Tertullian, and his conscious reflections on them. We come now to the problem of exegesis. Basic to the problems of language and imagery is the fact that Tertullian is impregnated with the Bible; almost every page gives evidence of this.

Now however familiar biblical language and imagery is to him, Tertullian knows that the biblical manner in using them is different, and in need of explanation. And so he glosses biblical words and expressions; so he comments on the special value which biblical imagery has. To this extent, the problem of exegesis has already been touched on. Tertullian has an acute sense of the otherness of the biblical mode of expression because he is so much a man of two worlds. In the preceding two chapters, we have seen his awareness of a tension between the classical and biblical; to some degree, this crossing of sources may be observed in his technical vocabulary of exegesis.

This is not the place for a theological view of Tertullian's exegesis. Adhémar d'Alès', G. Zimmermann², Heinrich Karpp', R. P. C. Hanson', and, most recently, Otto Kuss ${ }^{5}$ have written studies on Tertullian's approach to Scripture. Others have inquired into the closely connected questions of tradition ${ }^{6}$ and the regula fidei ${ }^{7}$. An introduction

1 A. D'Alès, La theologie de Tertullien (Bibliothèque de théologie historique), Paris, $1905^{2}$; ch. 3 (Inspiration, Canon, Texte; Exégèse: p. 242-254).

2 Gottrried Zimmermans, Die hermeneutischen Prinzipien Tetillians, Würzburg, 1937.

- H. KarpP, Schrift und Geist bei Tertullian, Gütersloh, 1955.

- R. P. C. Hanson, Notes on Tertullian's Interpretation of Scripture, JTS n. s. 12 (1961), p. 273-279.

- Oтто Kuss, Zur Hermeneutik Tertullians, in: Neutestamentliche Aufsätze (Festschrift für Prof. Josef Schmid zum 70. Geburtstag), ed. by J. Blinzer et al., Regensburg, 1963; p. 138-160.

- The following may be noted: Frans De Pauw, La justification des traditions non écrites chez Tertullien, Ephemerides Theologicae Lovanienses 19 (1942), p. 5-46; S. L. GreEnszade, Scripture and other doctrinal Norms in early Theories of the Ministry, JTS 44 (1943), p. 162-176; J. Quasten, Tertullian and 'Traditio', Traditio 2 (1944), p. 481484 ; H. von Gampenhausen, Tradition und Geist im Urchristentum, Studium Generale 
to the problem will be well by way of preface, however. After a glance at some words which show how Tertullian uses his training in rhetoric to examine Bible texts, five words will be used as a guide through his technical vocabulary of exegesis: aenigma, allegoria, figura, portendere, and simplicitas. These words, which bring us into contact with the chief operative words of his analysis, may well give a better overview of Tertullian's exegesis. Better, because much attention has been paid to the well-known rules of exegesis which Tertullian occasionally enuntiates. Those rules are, however, usually found in just those controversies where Tertullian is intent on limiting the portée of scriptural texts; obviously, they do not represent his entire exegesis. The rules ${ }^{1}$ do give a reasonable picture of Tertullian's attitude, when he is consciously reflecting upon the problem of biblical interpretation. Yet, the centrality of figura, for example, shows that Tertullian is quite often a very different exegete than his own rules might permit him to be.

It is useful to begin with a view of Tertullian's attitude towards Scripture; then, briefly, to call attention to the group of words which he draws from the technical vocabulary of rhetoric; then, to examine the five central words, aenigma, allegoria, figura, portendere, and simplicitas, with their related words, and those terms which are frequently found in their context.

4 (1951), p. 351-357; E. Flessman-Van Leer, Tradition and Scriphure in the Early Church, Assen, 1954.

7. B. Haegguund, Die Bedeutung der 'regula fidei' als Grundlage theologischer Aussagen, Studia Theologica 12 (1958), p. 1-44; on the forms of the regula fidei in Tertullian: J. M. Restrepo-JaramLlo, Tertuliano y la doble formula en el simbolo apostolico, Gregorianum 15 (1934), p. 3-58 on its use in Tertullian, E. Flessman-VAN LeER, op. cit., p. $161-170$.

Other studies, dealing with various aspects of biblical problems in Tertullian: Gregory T. Armstrong, Die Genesis in der Alten Kirche: die drei Kirchenväter (Beiträge zur Geschichte der biblischen Hermeneutilk 4), Tübingen, 1962, p. 93-140; R. M. BarLow, Biblical Inspiration in Tertullian, The Theologian (Woodstock, Maryland) 13.2 (1957), p. 40-44; Germano da Farriano, La chiusura della rivelazione in Tettulliano, Studia Patavina 5 (1958), p. 171-193; G. FanonI, Tertulliano interprete delle profezie messianiche (Dissertation, Gregoriana) Roma, 1957; V. Morel, Deductor omnis ueritatis. Het vers Jo. 16,13 bij Tertulliamus, Studia Catholica 16 (1940), p. 194-206; De ontwikkeling van de christelijke overlevering volgens Tertullianus (Catholica h. 1, 1946); Disciplina: le mot et l'idée représentée par lui dans les oeuvres de Tertullien, Revue d'Histoire Ecclesiastique 40 (1944-45), p. 5-46; Denise RuveT, Tertullien et l'Ecriture (diplôme soutenu en 1958 à la Faculté des Lettres de Lyon); R. E. RoBerTs, The Theology of Tertullian, London, 1924; C. Traletrt, 11 cristiano e la Scrittura in un passo di Tertulliano, Giornale Italiano Filologico 15 (1962), p. 254-256; A. VeLLICo, La rivelazione e le sue fonti nel 'de praescriptione kaereticonum' di Tertulliano (Lateranum, Nova Serie 1.4), Roma, 1935.

1 G. G. ZimmermanN, op. cit.; H. Karpp, op. cit., p. 24-29. 
Tertullian's deep familiarity with the Bible is beyond question. ${ }^{1}$ In his vocabulary - and, one may add, in his imagery - he is under the '..tyrannie du texte sacré.' $2 \mathrm{He}$ is not yet what one may call a commentator on the Bible; the fourth book Against Marcion is, however, a kind of correcting commentary on the interpolated and edited MarcionLuke, as the fifth book is on Marcion-Paul..$^{3}$ More important, he is constantly the controversialist, confronted with the problem of arguing from biblical texts, and with the rules which should govern this argument. Tertullian insisted on seeing scriptural passages in the original context in which they were uttered, and this rule is important for interpreting Tertullian's own rules of scriptural interpretation. Throughout his works, however, certain basic attitudes are clearly discerned, independent of the controversial needs of given occasions.

\section{The Bible in the Ghurch}

The tract de praescriptione is devoted to the proposition that Scripture, its interpretation, and the constitution of the canon, are of the Church. Hence arises the very possibility of heretical arguments (de praescr. 14.14); Scripture is the property of the Church (de praescr. $37.3 \mathrm{ff}$.). The canon of scriptures already appears as a settled unity. ${ }^{4}$ Noted as missing from his Old Testament, if one judges by citations in Tertullian are Ruth, Aggaeus, Esther, Tobias; the only positive problem in this region seems to have been offered by the book of Henoch, which Tertullian is anxious to accept as canonical, even though he knows that it is not in the Jewish canon (de cult. fem. 1. 3.1). The New Testament is more interesting; Tertullian defends Matthew, Mark and John against Marcion, and the canonical Luke which Marcion used (adu. Marc. 4. $5.3 \mathrm{ff}$.); he accepts Acts, rejected by Marcion (adu. Marc. 5. 1.6); in his analysis of Marcion-Paul, he appeals to the apostolic origin of Paul's epistles as the touchstone of their canonicity ${ }^{5}$, just as the guaran-

1 See, for example, A. Harnack, Tertullians Bibliothek christlicher Schriften, Sitzungsberichte der Königlichen Preussischen Akademie der Wissenschaften, Philos.Histor. Klasse, 1914, p. 303-334; p. 308.

- Rene Braun, Deus Christianorum, Paris, 1962, p. 351.

- See: E. Evans, Tertullian's Commentary on the Marcionite Gospel, Studia Evangelica (Oxford Congress, 'The Four Gospels in 1957') (TU 73), Berlin, 1959, p. 699-705; p. 689-700.

' On the canon of Tertullian's time, see: A. D'Alès, La théologie de Tertullien, p. 224-230.

- Cf. de praescr. 36.1 : '..percurre ecclesias apostolicas apud quas ipsae adhuc cathedrae apostolorum suis locis praesident, apud quas ipsae authenticae litterae eorum recitantur sonantes uocem et repraesentantes faciem uniuscuiusque.' 
tee of faith is in the apostolic character of the churches (adu. Marc. 4. 5.3). It is interesting to note that there are gradations of authority in the New Testament, in Tertullian's estimation. He removes Hebrews to another, slightly lower level, though accepting it as canonical (de pudic. 20.2), and seems to place a step of gradation between the Gospel(s) and the apostolicum instrumentum. ${ }^{1}$ Hermas seems to be accepted as authoritative in de orat. 16.1, but is rejected in de pudic. 10.12;20.2; The Acta Pauli are attacked as being not genuine (de bapt. 17.5). One of Tertullian's complaints against the heretics is the fact that they not only misinterpret the scriptures, but also introduce 'non-canonical' scriptures (de praescr. 17.1; de resurr. 63.8); arguments here, however, as also arguments on interpretation, are to be settled by a prescriptive appeal to the original, apostolic origin of doctrine; Scripture is of the Church.

Used within the Church, Scripture is a prime source of Christian songs (apol. 39.18); the reading of Scripture is central (de cult. fem. 2. 11.3; de anim. 9.4). Scripture is to the present time, what the prophets were to the past (apol. 22.9); unlike Justin, Tertullian does not tell us much of the Christian gathering, but does mention that the Christians come together '..ad litteranum diuinarum commemorationem..' (apol. 39.3). It seems that there was an attempt to select passages, appropriate to the time and occasion, and that the lectio continua was not always practiced. ${ }^{2}$

\section{The Basis of Revelation}

Tertullian elaborated a way of looking at reason, revelation and the world which we can trace throughout his work, and which is consistent with his eventual passage to Montanism. He may rail against philosophy', but he uses it, nonetheless. When he cites Seneca, who is 'Seneca

1 While we cannot argue from Tertullian's uses of instrumentum to the existence of an instrumentum euangelicum and an instrumentum apostolicum, as R. BRAUN, with TH. ZAHN, argues against H. RöNsCH (see Deus Christianorum, p. 463-472; p. 465, note 3), it is clear nonetheless that Tertullian regards the New Testament as an articulated and differentiated whole, where the Gospel(s) take a temporal and authoritative precedence.

2 See: P. GLAuE, Die Vorlesung heiliger Schriften bei Tertullian, ZNTW 22-23 (1923-24), p. 141-152; E. Dekrers, Tertullianus en de geschiedenis der liturgie (Catholica, 6.2), Brussel en Amsterdam, 1947, p. 36-39.

- ANDré LABHARDT, in his article, Tertullien et la philosophie ou la recherche d'une position pure, Museum Helveticum 7 (1950), p. 159-180, gives the best description of Tertullian's stand on philosophy, describing it as a 'pure position' (the description of E. Gilson for the task of a thinker), of absolute rejection. See the literature cited by LABHARDT, and the comments on his article by F. REFOULE, Tertullien et la philosophie, Revue des sciences religieuses 30 (1956), p. 42-45. 
saepe noster' (de anim. 20.1), it is one indication among many of his debt to the Stoa. In that system, and even in the common philosophy of the time, a double approach to the knowledge of God was used: the macroand microcosmic. In the first, the great and orderly kosmos furnished the proof; in the second, the little universe of man. For Tertullian, God is the most known. The knowledge of God is written in the world (adu. Marc. 2. 17.1); Tertullian criticises the pagans, upon whom natural disasters had come because they had not sought out God (apol. 40.10: the thought, if not the language of Rom. $1.18 \mathrm{ff}$. is behind this). God is the first known (adu. Marc. 2. 2.1); known in his works (adu. Marc. 2. 3.1), even previous to revelation (de resurr. 2.8); his existence is something which all know, to wbich all assent, in contradistinction to other truths, like the resurrection (de resurr. $3.1 \mathrm{ff}$.).

The little work de testimonio animae $e^{1}$ develops the microcosmic view. Tertullian finds a proof of God in the untutored soul's spontaneous utterances. A pre-development of this argument comes in the apol. 17.6: ' $O$ testimonium animae naturaliter Christianae!'. It is important to note that Tertullian uses this argument precisely as one which is more certain than a long reasoning process from literary sources. ${ }^{2} \mathrm{He}$ convokes the soul to give its testimony; from its natural expressions, God is good, if God wills, etc. the soul gives evidence to the existence of God, evidence which is the more compelling for being original, and not immediately affected by learning. Tertullian returns to this argument; in the de carn. 12. 4-5, for example, he cites the de test. an. The nature argument, and that from the soul's witness are interconnected: 'Magistra natura, anima discipula est. Quicquid aut illa edocuit aut ista perdidicit, a deo traditum est, magistro scilicet ipsius magistrae.' (de test. an. 5.1). The relation of soul and nature results in a kind of sensus publicus ${ }^{3}$; and this explains why some philosophers have happily chanced upon the truth, though they then proceeded to adulterate that truth with their own ideas (de anim. 2.1). Even if the soul does answer in this way, one may argue that it has been influenced by literature. But Tertullian answers that the soul is prior

1 See: G. Qusspel, Anima naturaliter christiana, Eranos Jahrbuch 18 (1950), p. 173182; Het getuigenis der ziel bij Tertullianus, Leiden, 1952.

2 KarL Hold, in a general view of Tertullian: Tertullian als Schriftsteller, Gesammelte Aufsälze zur Kirchengeschichte, III Vols., Tübingen, 1923; Vol. III, p. 1-12, reads the sentence in de test. an. 1.4, 'Tanto abest, ut nostris litteris annuant homines, ad quas nemo uenit nisi iam Christiantu' as an indication of scepticism in Tertullian; see p. 4, and supra, ch. 1, p. 35-36.

${ }^{3}$ Cf. de anim. 2.1: '...sed et natura pleraque suggerentur quasi de publico sensu, quo animam deus dotare dignatus est.'; de coron. 6.1: 'Quaerens igitur dei legem habes communem istam in publico mundi, in naturalibus tabulis...'; see: J. H. WAszinK, De Anima, note ad de anim. 2.1 , p. 99; note ad de anim. 41.3 , p. $454-455$. 
to letters, speech prior to books, man prior to the philosopher and the poet (de test. an. 5.4). And, even if the soul be influenced, the radical source of its knowledge and that influence is to be found in the scriptures (de test. an. 5.6). What is important to note is the explicit appeal by Tertullian to a more certain topos, to a non-literary argument.

In the apologeticum, Tertullian deals with the sources of the knowledge of God. First comes the argument from his works (apol. 17.4 $\mathrm{ff}$.); then from the soul (17.4), and finally, from Scripture. Scripture comes to confirm, '..plenius et impressius..' (18.1) the silent revelation of nature, and the witness of the soul (see also de resurr. 12. 7-8; 14.1). Now, of all these arguments, it seems that Tertullian is least at ease with the literary-scriptural one. Against Marcion, he insists that God is known even without Scripture (adu. Marc. 1. 10.1-3); and, while the polemic with Marcion demanded these arguments, they fit in with a general pattern visible in Tertullian. Marcion's God is unknowable, except through the scriptures, and Tertullian holds this to be an untenable position (adu. Marc. 5. 16.3). We find evidence of Tertullian's diffidence toward the literary argument. He will back up his claim that Christians are not to wear crowns with an appeal to nature (de coron. $5.1 ; 6.1$, but here appealing explicitly to Rom. 1.25-27). Nature even testifies to the resurrection (de resurr. 12.8: 'Praemisit tibi naturam magistram, summissurus et prophetiam, quo facilius credas prophetiae discipulus ante naturae...'). Tertullian cites such arguments here, even though he has conceded that the resurrection is an exclusively Christian truth, and that the witness of the soul is useless here (de resurr. $1.1 ; 3.3$ ). Then, at the end of the de resurrectione, after buttressing Scripture with arguments from nature, Tertullian, well into his Montanism, appeals to the revelation of the Paraclete; for the argument from Scripture is not wholly clear, even when it is taken as a whole (de resurr. $10.1 \mathrm{ff}$.), even when allowance has been made for development in Scripture (22.2). Unfortunately, the scriptures can be misunderstood; otherwise, there would be no heresy (40.1 ff.); and, in this context, the final closing lines, citing the clarity of the Montanist revelation, come as no surprise. The words which appear in the closing sentences: dissimulare, ambiguitas, parabola, aperta atque perspicua praedicatıo, etc., all show what Tertullian sought: a clarity which would make further argument impossible (de resurr. $63.7 \mathrm{ff}$.).

Thus he also appeals to prescription, to the regula, to disciplina, also, to answer problems arising from Scripture. His appeal to the witness of the soul is an appeal to a non-literary argument (it is not evident that it is an appeal to a non-scriptural argument, as such); he reinforces Scripture with proofs from nature; and this scepticism towards the 
scriptural argument is consistent with his eventual Montanism, where Tertullian thought to find certainty. ${ }^{1}$

\section{SPIRIT AND ScRIPTURe}

That the Spirit is the author of Scripture is strongly expressed by Tertullian (de patient. 7.5; adu. Marc. 5. 7.2; de resurr. 13.3, etc.). The Scripture is therefore one; Peter and Paul must agree (de orat. 20.2); John cannot be thought to have conceded what Paul denied (de pudic. 19.3). Only late in his Montanist period does Tertullian insist on the action of the Spirit in understanding the scriptures. ${ }^{2}$ The authority of the scriptures is more assumed than proven by Tertullian. In the apologeticum we find the familiar idea that the scriptures are the oldest, the primordial source of wisdom, even the wisdom of the philosophers. To detail their claim to antiquity would take too long, and so he appeals to their majesty (apol. $19.5 ; 20.1$ ); the great claim of the scriptures is that they foretell the future; what they announced is now taking place, and this is the guarantee of the other prophecies.

Tertullian, especially the later, Montanist Tertullian, makes distinctions on the authority of, and in, the scriptures. In Paul, we find some opinions which are human (even if they be the opinions of an Apostle), and injunctions which are divine; and the divine is what must be followed (de castit. 3. 6; see $4.5 \mathrm{ff}$.). The claims of the Spirit are imperious, and must be followed (de idol. 4. 5). Then again, a strange passage in the adu. Prax. would seem to limit Scripture by an a priori. Tertullian would preserve the august position of the Father, while accepting the humility of the Son in the Incarnation. ${ }^{3}$ But, he comments: 'Scilicet et haec nec de Filio Dei credenda fuissent, si scripta non essent, fortasse non credenda de Patre, licet scripta...' (adu. Prax. 16. 6; cf. 16. $3 \mathrm{ff}$.). But this is Tertullian the controversialist, and the phrase cannot be pressed. In the de pudic., in keeping with his limiting rules there, he prefers to see less in Scripture, rather than exaggerate in its interpretation (de pudic. 9.22).

\section{The Unity of the Two Testaments}

The two great preoccupations of early and later patristic exegesis were the unity of the two testaments, and, closely connected with this, the

1 Cf. Paul Moncraux, Histoire littéraire de l'Afrique chreltienne, I, p. 437-438.

2 Again, see the remarkable text, de resurr. 63.7-10.

2 In the adu. Marc. 2. 27.6, we find a striking phrase which illustrates this same view of the Father: 'Igitur quaecumque exigitis deo digna, habebuntur in patre inuisibili incongressibilique et placido et, ut ita dixerim, philosophorum deo...'. 
allegorical interpretation of the scriptures. ${ }^{1}$ These concerns are already present in Tertullian. He vindicates the Old Testament as the source of all the wisdom of the ancient philosophers. Thales and Solon agree with, and were influenced by the prophets (apol. 19, fragm. Fuld. 4). This is primarily concern of the apologetic works. Running through them, and through the other works of Tertullian, is the theme of continuity between the two testaments. Jews and Christians are distinguished from one another by this: the Jews thought Christ to be simply a man like any other, even though he had come to reform the discipline which they had neglected (apol. 21.7), and they await the Messias still, while the Christians believe him already come in the person of Christ (apol. 21.15; de cult.fem. 1. 3.3; adu. Marc. 3. 16.1). There is a continuity between Jews and Christians (de test. an. 5.6), between Law and Gospels $^{2}$ (scorp. 2.2; adu. Marc. 4. 11.11; apol. 45.1; de orat. 7.3; ad uxor. 1 . 2.2), a continuity which, as we have seen, Tertullian expresses through vegetation imagery. ${ }^{3}$

'Totum, quod sciam, uetus testamentum omnis haereticus inridet..', says Tertullian (adu. Marc. 5. 5.10), and it is in his controversy with Marcion that he most applies himself to defend the unity of the two testaments. 'Separatio legis et euangelii proprium et principale opus est Marcionis...' (adu. Marc. 1. 19.4; and see 4-5). The criticism which Tertullian makes of Marcion-Luke and Marcion-Paul is to show that they are unintelligible unless they be read in the light of the Old Testament. The very newness of the Gospel is already announced by Isaias (adu. Marc. 1. 20.4-5), and Tertullian is able to exclaim: ' $O$ Christum et in nouis ueterem!' (ibid. 4. 21.5). It is important to note that it is here, in the adu. Marc., that we find a theoretic defence of allegory.

The continuity between Old and New Testaments is also seen in the presence of Christ, even in the Old Testament. He is figured in the person of Moses (adu. Marc. 2. 26.4); he acted in the Father's name, spoke with the patriarchs and prophets (ibid. 2. 27.3); the Psalms are his prayer (adu. Prax. 11.7); in the Old Testament, he was 'learning to deal with men' (adu. Marc. 3.9.6; cf. adu. Prax. 16.3), learning to address, to free, and to judge them (de cam. 6.8). Christ is everywhere announced in the Old Testament (adu. Marc. 3, passim); he is with the

1 The two great pre-occupations of later exegesis. See HENri de Lubac, Exégèse médiévale: les quatre sens de l'Écriture IV Vols., (Théologie, nos. 41, 42, 59), Paris, 19591963; partie premiere, p. 305 f.; p. 373 ff.

2 Matth. 5.17, on the fulfillment, not the destruction of the Law by Christ, is the most frequently cited single text from Scripture in Tertullian, occurring at least 29 times.

See supra, ch. 2, p. 68-73. 
three young men in the furnace (ibid. 4. 21.8). He is predicted by the prophets, and it is he who is the singer: 'Ille (scl. David) apud nos canit Christum, per quem se cecinit ipse Christus...' (de carn. 20.3; cf. de resurr. 22.3). His coming marks the division of the two testaments (adu. Iud. 8. $13 \mathrm{ff}$; adu. Marc. 5. 2.1, etc.).

Tertullian's attitude to the Old Testament changes, as his controversial aims change. In the $a d u$. Iud., his attitude towards the Law is rather negative. The Law was already given in germ to Moses ( $a d u$. Iud. 2.6).${ }^{1}$ Now this is in polemic with the Jews. Yet, it coincides with that earlier view that we have seen; revelation comes in progressing steps, and Scripture confirms what is already present in the world. At times, Tertullian regards the Old Testament with a certain disdain, as when he speaks of the 'old liberty' (ad uxor. 1. 2.3); it was the time of the letter, the New Testament of the spirit (but, paradoxically, both are of the same God (adu. Marc. 5. 11.4)). In the later works, he seems to take another view, and even comes to call the Gospel '...legem proprie nostram,..' (de monog. 8.1). ${ }^{2}$ Tertullian is impatient with those who claim that the New Testament has made obsolete all that is in the Old (de ieiun. 2. 2). The whole Law remains (de resurr. 6. 3-5) in its essentials; Tertullian can range through both testaments, uniting them along images, finding parallels; the two testaments are one, not only in his theory, but also in his imagination. They are harmonious with one another, as their revelation is also harmonious with that silent revelation of nature, and the witness of the soul.

\section{Allegory}

A better view of Tertullian's attitude towards allegory will be had from the study of the technical vocabulary of exegesis, especially from a study of the words aenigma, allegoria, and figura. The two preoccupations: the unity of the two testaments, and the application of allegory to their interpretation, are closely associated, and it is not accidental that Tertullian defends allegory against Marcion, and sharply restricts its use in the de pudic.; in the once case, it is chiefly the interpretation of the Old Testament as preparatory for the New that he would assure;

1 adu. Iud. 2.6: '...in hac generali et primordiali dei lege, quam in arboris fructu obseruari deus sanxerat, omnia praecepta legis posterioris... fuisse cognoscimus, quae suis temporibus edita germinauerunt. Cf. ibid. 2.3: 'In hac enim lege Adae data omnia praecepla condita recognoscimus, quae postea pullulauerunt date per Moysen...

Cf. R. P. C. Hanson, art. cit., JTS n.s. 12 (1961), p. 279: 'The tendency to turn Christianity into a baptised Judaism, observable in many aspects of the life ... of the third century Church, finds its earliest exponent in Tertullian.' 
in the second, it is an interpretation of the New with which he disagrees. For the Old Testament was unclear, expressed in hidden terms, containing the sacramenta obumbrata; and reuelare is of the New Testament (adu. Marc. 5. 6.1-5).

To understand Tertullian's attitude towards allegory, it is necessary to understand his attitude towards literary argument in general. That scepticism which we have already noted is frequently present in Tertullian. There is more, however. Tertullian has that Christian complex which runs through Jerome and Augustine also, in regard to literature and poetry. ${ }^{1}$ He reproaches the pagans for honoring poets, despite what they said of the gods (ad nat. 2. 7.9-10); his apologetic is often directed against those two great sources of authority among the pagans, the philosophers and the poets (apol. 47.11). Moses was a prophetic, not a pastoral poet (and therefore, to be taken seriously; de coron. 7.3). This is said parenthetically; as he remarks also in the de anim: 33:8: 'Pauum se meminit Homerus Ennio somniante; sed poetis nec uigilantibus credam... He adopts a relentlessly literal attitude towards the poets; as also, when he treats the story of Psammeticus (told by Herodotus, among others). That king endeavored to discover which language, and therefore, which people, were the oldest. The story is subjected to a pitiless analysis by Tertullian (ad nat. 1. 8.2-8). It is not wise to draw too much from this passage, as Tertullian the controversialist presses his advantage; yet, he is so often the controversialist. If he is capable, in his catechetical works, of genial, 'open' interpretations (de bapt. 8.4, e.g.), he often betrays a dialectical, either-or mentality, which does not seem wholly determined by the controversy at hand. So he attacks efforts to allegorise the story of Saturnus; 'Aut Saturnus fuit aut tempus' (ad nat. 2. 12.20, see $17 \mathrm{ff}$.); he has no patience with attempts to expose mystery cults in allegorical fashion ( $a d u$. Val. 1.3); he is irritated by the difficulty with which one comes to grips with the Valentinians: 'Si subtiliter temptes, per ambiguitates bilingues communem fidem affirmant.' (adu. Val. 1.4). The option is frequently either-or; there is no middle ground. The famous passage from de praescr. 7. 9-11, which begins: 'Quid ergo Athenis et Hierosolymis? quid academiae et ecclesiae?' is more than a rhetorical flourish. (Cf. de spect. 26.4; apol. 13.2; de anim. 16.7; de coron. 1.1; 11.4; 12.5; de idol. 19.2).

Tertullian writes, and thinks, in terms of oppositions (de cult. fem. $1.2 .5 ; 8.2$; and passim in Tertullian). In a philosophic argument he presses Hermogenes: '..omnis res aut corporalis sit necesse est aut incorporalis

1 Cf. F. W. C. L. Schulte, Het heidendom bij Tetulliarats, Nijkerk, 1923, p. 37-43, and passim. 
...Certe post corporale et incorporale nihil tertium..' (adu. Hermog. 35. 2-3). In much the same way, he urges, against Marcion: '..aut noluit condere quid aut non potuerit. Tertium cessat.' (adu. Marc. 1.11.7). Tertullian is often the 'plain man', who wants things to be simple and clear (de carn. 13. 1-3); 'Fides nominum salus est proprietatum.' (ibid. 13.2). In his later moralising, this dialectic appears strongly. The de fug. 5.1 reflects this attitude; we find the aut-aut terminology in 7.1 ; and, at the close of the de fug., he cites Matth. 19.12, and draws the conclusion: '..sed reputa Deum dixisse: "Qui capit, capiat", id est: "qui non capit, discedat".' (de fug. 14.2). The most striking form of this either-or option is to be found at the close of the de monog. (17.5): 'Redi in Adam uel priorem, si in nouissimum non potes...Exhibe tertium Adam et hunc digamum... Now all these texts may not be pressed; a psychology of Tertullian is not the intent here. ${ }^{1}$ They do, however, illuminate his use of allegory.

We haye his own reference to an explicitly allegorical work, now lost, de spe fidelium, which intended to give an allegorical interpretation of the restitution of the land of Juda (adu. Marc. 3. 24.2). ${ }^{2}$ Against Marcion, Tertullian gives a theoretical defense of the allegorical method. Marcion did not himself allegorize ${ }^{3}$; his reading of the Old Testament was a literal one, in order to present it as laughable. But Tertullian is able to show that even Marcion-Paul allows allegory (adu. Marc. 3. 14.4, etc.), he cites the texts 1 Cor. 9. 9-10; 10.4; Gal. 4. 22-25; Eph. 5. 31-32 (adu. Marc. 3. 5.4).

Previously, Tertullian had exposed two principles of the interpretation of Scripture, in the hope that the discussion with Marcion would then be conducted ad causas, with the form of the scriptures agreed upon. The first principle, a view of time and prophecy, can be discussed later. The second: 'Alia species erit, qua pleraque figurate portendentur per aenigmata et allegorias et et parabolas, aliter intelligenda quam scripta sunt.' (adu. Marc. 3. 5.3). The literal interpretation, Tertullian suggests, is impossible in these places': 'Nam et montes legimus destillaturos dulcorem, non tamen, ut sapam de petris aut defrutum de rupibus speres, et terram audimus lacte et melle manantem, 〈non tamen〉 ut de glebis credas te umquam placentas et Samias coacturum, quia nec statim aquilicem et agricolam se deus repromisit 1 Cf. the essay of G. J. DE VRIEs, Bijdrage tot de psychologie van Tertullianus (Proefschrift, Vrije Universiteit, Amsterdam), Utrecht, 1929.

-Jerome refers to this book several times as also to another, de Aaron uestibus (cf. adu. Marc. 4. 13.4), known to Jerome only through a list of Tertullian's writings. See: J. Quasten, Patrology, II, p. 318.

A. von Harnack, Marcion: das Evangelium vom fremden Gott, p. 61 ff.; 4.

- Cf. J. PÉpin, A propos de l'histoire de l'exegèse allegorique: l'absurditt, signe de l'allegorie, Studia Patristica I, p. 395-413. While Tertullian is not mentioned here, the rule which Pépin outlines has its analogue in Tertullian. 
dicens: ponam flumina in regione sitienti et in solitudine buxum et cedrum....' (adu. Marc. 3. 5.3). It is the same Tertullian here, who with a certain sarcastic literalism, shows that allegory must be applied, to save the very sense of the scriptural statement.

He returns to $\mathrm{Gal} .4 .24$ in the fifth book against Marcion, and glosses allegorica (as we have seen in Ch. 1)1 with '..id est aliud portendentia..'. The best tradition of allegorical interpretation will in fact be occupied with the prefiguring of Christ in the Old Testament: Christ, and the Church. And Tertullian is already in this tradition. ${ }^{2}$ Gal. 4. 22-25 is the great text, to which later authors will appeal to found a Christian theory of allegory. ${ }^{3}$

In the adu. Marc., Tertullian uses allegorical interpretation moderately, and only when compelled to; or, when the very text of MarcionPaul permits him to. $\mathrm{He}$ is sometimes laborious in detailing the meaning of a figura (see, e.g., adu. Marc. 3. 16.4-5), and that peculiar realism and literalism of Tertullian, already observed in his dependence on images, is visible here also. This will become clearer in an analysis of his use of figura.

There is a tension between Tertullian's theoretic acceptance of allegory, and his use of it. In his catechetical works, notably in the de bapt., de paenit., de patient., he is much more prone to 'open' interpretations; while in controversy, he is severely limiting. '..malumus in scripturis minus, si forte, sapere quam contra...' (de pudic. 9.22); significantly, the phrase comes in a controversial, late moral work. This tension is sometimes expressed as being that between a figura, which he accepts, and another reading, which views a passage simpliciter (see, e.g. ad uxor. 1. 2.2).4 More frequently, this tension appears in terminology similar to that which follows: 'Haec aut nega scripta, aut quis es ut non putes accipienda quemadmodum scripta sunt, maxime quae non in allegoriis et parabolis sed in definitionibus certis et simplicibus habent sensum.' (adu. Prax. 13.4). It is surely a paradox that Tertullian defends allegory, against Marcion, by showing the absurdity of a literal interpretation; and that it is precisely this literalism which makes him usually prefer the simple reading. Salua simplicitate scripturae, he is prepared to find deeper

1 See supra, p. $54 \mathrm{ff}$.

2 Cf. J. Daniélou, Les divers sens de l'Ecriture dans la tradition chrétienne primitive, Ephemerides Theologicae Lovanienses 24 (1948), p. 119-126.

s Cf. Henri de Lubac, Exégèse médiévale, première partie, II, p. $377 \mathrm{ff}$.

1 ad uxar. 1.2.2: 'Sed licet figura tum in synagogam et ecclesiam intercesserit, ut tamen simpliciter interpretemur, necessarium fuit instituere quae aut amputari aut temperari mererentur.'. So reads Kroymann. But Christine Mohrmann, with J. H. Waszink, reads: 'figuraliter in synagoga ecclesia'; rightly, as it seems. 
meanings in it (adu. Marc. 4. 24.10). Something of that literary scepticism which has been exposed above, makes Tertullian prefer those scriptural utterances which '..nudae et simplices et ab omni allegoriae nubilo purae defendi possunt..' (de resurr. 20.7).

If aenigma, almost always, and allegoria, frequently, is found in the context which suggests vagueness, and ambiguity, it is different with figura. Figura is not co-terminous with allegory, of course. Tertullian, as we will see, is far more at ease with this word in his technical vocabulary of exegesis. This brief introduction has already introduced us to those five central words: aenigma, allegoria, figura, portendere, and simplicitas. A study of them will give a better view of Tertullian's attitude in practice towards scriptural interpretation along their lines.

\section{The Silence of Scripture}

Tertullian prefaced the discussion of Scripture with that appeal to the silent revelation which the world offers, and with the witness of the soul. He dresses a legal prescription against the heretics, to avoid discussion on the meaning of Scripture; and he is able to range through Scripture in his catechetical works, uniting texts along the axes of images, open in his interpretation. When dealing with the heretics, however, he must meet them on scriptural grounds; and a basis for what he wants to hold is sometimes hard to find there. He is then confronted with the problem of the silence of Scripture, and he meets this in various ways. ${ }^{1}$

In the de spect., for example, his adversaries within the Church demanded scriptural proof that attendance at the games was not consistent with Christian principles (de spect. 20.1). They were even able to find scriptural texts which seemed to justify their position (ibid. 20.2). Tertullian attempts to meet them on their own ground, and reads Ps. 1.1 in a tortured way. 'Felix uir..qui non abiit in concilium impiorum et in uia peccatorum non stetit et in cathedra pestium non sedit...'; the text (de spect. 3.3) is made to serve Tertullian's controversial ends. ${ }^{2}$ Interestingly, Tertullian finds the first meaning of Ps. 1.1 and ff. to be the prediction of the plots of the Jews against the Lord. ${ }^{3}$ Yet, he says, the Scripture

1 Gr. O. Kuss, art. cit., p. 151-152 and note 58 ibid.

2 This reading of $P$ s. 1.1, applying it to the games, is also found in rabbinical exegesis, in the 'Abodah Zarah'; cf. R. LoEw, The Jewish Midrashim and Patristic and Scholastic Exegesis of the Bible, Studia Patristica, I, p. 492-514; p. 494; and in Clement of Alexandria, Paedag. 3. 11.

s The interpretation of the uir iustus as Joseph of Arimathea is already suggested in Luc. 24. 50-51. Tertullian develops this in adu. Marc. 4. 42.8. 
is wide in its possible applications, and a general prohibition may be drawn from a particular one (de spect. $3.4 ; 3.7)$. In all events, he is not wholly content with his reading of Ps. 1.1, and he retires to firmer ground, in the command against all forms of concupiscentia (ibid. 14.2-3).

If he notes that Scripture nowhere forbids marriage (ad uxor. 1. 3.2), and sometimes draws nothing at all from the silence of Scripture: '...sed nihil de hoc constat, quia scriptura nihil exhibet..' (de carn. 6.10; cf. 7.3; 20.1), Tertullian does not always remain satisfied with the position of non constat. In the face of a silence, he goes farther. In the adu. Hermog. he approaches the position that silence equals a denial $(20.5 ; 22.5)$; and, in the later, moral tracts, feeling the lack of scriptural bases for his positions, Tertullian tends to elevate silence into a principle: ' $E t$ facile est statim exigere, ubi scriptum sit, ne coronemur. At enim ubi scriptum est, ut coronemur?' (de coron. 2.4); here again, however, he finds a better position by taking refuge in the argument from tradition. 'Negat scriptura quod non notat' is the formulation which we find in the de monog. 4.4; and, significantly, at the beginning of this chapter, Tertullian appeals to the Montanist Paraclete, the restorer of discipline $(4 ; 1)$. Such an appeal, together with those made to nature and to discipline (de uirg. uel. 16. 1-2) is an index of Tertullian's growing uncertainty with scriptural proofs. His a priori is growing in this period ${ }^{2}$; and Tertullian seems to develop from a position where Scripture is thought necessary, through the stage where the silence of Scripture is interpreted as a prohibition, to the final appeal to the Paraclete, whose revelation brings the Gospel itself to maturity (de uirg. uel. 1.6-7). This complex is to be seen in parallel with the concern of Tertullian for clarity, and his scepticism towards the literary argument.

\section{The Rules of Exegesis}

Karl Holl remarked that no one of his time had formulated the norms of a good exegesis as well as Tertullian ${ }^{3}$, and it is this aspect of Tertullian the exegete that has attracted the most attention. ${ }^{4}$ The rules of

1 See Frans De Pauw, La justification des traditions non écriles chez Tettullien, Ephemerides Theologicae Lovanienses 19 (1942), p. 5-46; E. Flessman-VAN Leer, Tradition and Scripture in the Early Church, p. 145 ff.

2 A. D'Alìs, La thélogie de Tetrullien, p. 253.

- Tertullian als Schriftsteller, Gesammelte Aufsätze zur Kirchengeschichte, III, p. 5. Holl comments that, while Tertullian does not himself always use his own principles, their enunciation remains important.

- D'Ales, Zimmermann, Karpp and Hanson all dwell on the rules of exegesis formulated by Tertullian; Zimmermann and Karpp in the most systematic fashion. 
Tertullian are systematised by Heinrich Karpp ${ }^{1}$, who admits the casual, occasional nature which these rules have; quite often, they spring from the controversy of the moment. Many of his principles have already been sketched. Thus, Tertullian would view the Scripture as a whole, for it is all from the Spirit. He even appeals to the whole tenor of Paul to justify his intransigent stand in the de pudic.: 'Concede iam tot ac talibus sententiis unum illud quod tenes. Pauca multis, dubia certis, obscura manifestis adumbrantur...' (de pudic. 17.18). Similar arguments are made elsewhere (cf. e.g., de resurr. $21.1 \mathrm{ff}$; adu. Prax. 26.1, etc.). The heretics seize on texts which support their arguments, and ignore all the others (adu. Prax. 20. 1-3). This appeal to the whole of Scripture is certainly a constant in Tertullian (de resurr. 18.1), and he insists that one must take the whole of Paul, and not just one phrase (de resurr. 10.3).

The context of a scriptural statement is also an important norm for Tertullian. A good example is found in his exegesis of Matth. 7.7, 'quaerite et inuenietis.' This example is the more interesting, in that Tertullian would limit the curious perusal of the scriptures by Christians. Both heretic and Christian appealed to the text to justify their varying searches; against the Christians, Tertullian observes: 'Fides tua te saluum facit, non exercitatio scripturarum' (de praescr. 14.3). To limit the text from Matthew, Tertullian replaces it in the exact historical context in which it was uttered: it was said to the Jews, when they still might search out and find Jesus. But once he is found, in faith, this verse no longer applies. Like many of the sayings of the scriptures, it has the value for us, not of an injunction, but of an example (de praescr. 8.1; see 8.16). ${ }^{2}$ We find many similar statements; if Paul says that he baptised no one, this is to be seen in the context in which he was writing (de bapt. 14.2); to understand what Paul means in 1 Cor. 7.1214 , one must remember that the situation of those counsels on marriage was very different to the present one (ad uxor. 2. 2.1-2).

The historical context is important; so too is the stylistic one. When still accepting Hermas as a text which demands respect, at least, he explains how a text from it does not constitute a precept for prayer (de orat. 16.2). Tertullian appeals to the sentence which follows Rom. 7.2 to deprive his adversaries of their claim to freedom of marriage (de monog. 13.2); he puts a citation from 1 Joh. 1.7 into the context of the preceding and following sentences (de pudic. $19.10 \mathrm{ff}$.). But, there

1 See H. KarpP, art. cit., p. 21-29.

2 Tertullian goes on to find a stronger argument, however, showing the search must stop somewhere. As frequently in Tertullian, a scriptural argument finds a confirming support drawn from other sources. 
are tensions in Tertullian. As with the citation from Ps. 1.1, he is ready to claim a larger portée for scriptural utterances: 'Nulla enuntiatio spiritus sancti ad praesentem tantum materiam, et non ad omnem utilitatis occasionem dirigi et suscipi debet.' (de cult. fem. 2. 2.5). He follows this rule, generally, in his catechetical works; in the heat of controversy, he is much more apt to limit Scripture. Thus, he accepts the Lucan parables of mercy in the de paenit. (8.4 and ff.), and restricts them sharply in the de pudic. (11.2, and passim). There has been a considerable development in the thought of Tertullian, of course. The position taken in the de pudicitio is an extreme one: '..nihil aduersus nos praeiudicare..' he says of those texts which show the mercy of the Lord. Limiting inconvenient texts to the peculiar conditions of the earthly preaching of Christ, Tertullian has taken a long step towards making the Scripture irrelevant.

Tertullian can bring all his learning to bear on the interpretation of the Bible. He is alive to language, and the way in which people speak and write. He appeals to the ordinary way in which people talk, to explain the text: 'Et tamen Iesus non ipse tinguebat uerum discipuli eius..' (de bapt. 11. 1-2). Thus, '..ex forma simplici loquelae humanae...' he refutes the subtle reading of the heretics (adu. Marc. 5. 5.7). Subtlety is inimical to Tertullian, when he finds it in his adversaries. They are always prepared to ..simplicia torquere..' (adu. Hermog. 19.1; cf. 27.2; adu. Marc. 4. 19.6; 43.7). But Tertullian can also be subtle, and he himself does not remain on the level of simplicitas (adu. Marc. $5.10 .1 \mathrm{ff}$. ; de uirg. uel. $4.1 \mathrm{ff}$.).

The appeal to the normal rules of language brings us into the area of rhetoric. We will see some of the rhetorical language which he brings to bear on the interpretation of Scripture. He is aware that Christ was a man of his time and culture, and that he therefore used forms which were adapted to them (adu. Marc. 4. 11.12).

Tertullian generally opts for the simpler reading. This is in keeping with his limiting principle. The argument from Scripture rarely stands alone in Tertullian; he reinforces his proof text with other arguments, drawn from nature, discipline, tradition; in his intelligence of texts, and even of images, his exegesis is '..etrangement verbale..'1 His limiting principles, clearly, are most highly developed in the rules which we find in the de pudicitia $(7.1 \mathrm{ff}$.). Tertullian is faced with the problem of interpreting those Lucan parables of mercy (Luc. $15.4 \mathrm{ff}$; 15.8; 15.11). He will have it that some sins cannot be forgiven, and so he sets about

1 A. D'Alès, La théologie de Tertullien, p. 247. In de praescr. 9.2 Tertullian would explicitly avoid such verbal arguments from Scripture. 
the interpretation of these troublesome parables. In so doing, he enunciates excellent rules 1 , whose common sense would seem to recommend them. But the use that Tertullian himself makes of them is something else again. Where other schools of exegesis will seize on words, and details, he observes that some details are 'simply there' (de pudic. 9. 2-3). Why the hundred sheep? why ten drachmas? and why is the broom there? 'Huiusmodi enim curiositates et suspecta faciunt quaedam et coactarum expositionum subtilitate plerumque deducunt a ueritate. Sunt autem, quae et simpliciter posita sunt ad struendam et disponendam et texendam parabolam, ut illuc perducantur, cui exemplum procuratur.' (de pudic. 9.3).

Tertullian would limit the interpretation by the already known. The control over interpretation is offered by the regula fidei. In apol. 47.10 , where it is implied that there are differences of opinion, even among the Christians, resulting in a distressing variety of opinions, Tertullian appeals to the '...regulam ueritatis..'. The de praescr. would avoid disputes on Scripture by the appeal to received truth, and the rule of faith (de praescr. 13. 1-6). Similar appeals are made in adu. Prax. 2. 1-2; de uirg. uel. 2.1 ; de pudic. 8.12 , in different ways. This appeal is made as to something certain, which makes the doubtful clear. If Scripture itself is a regula (adu. Marc. 3. 17.5), there remains that obscuritas, ambiguitas (see de praescr. 14.1; de resurr. 63.7-8, etc.), so distasteful to Tertullian. If some inquiry into Scripture is allowed, it ought to be done within the Church (de praescr. 12.5); but too much curiosity is useless (ibid. $14.1 \mathrm{ff}$.). ${ }^{2}$

The regula is a negative, confirming norm, to which Tertullian appeals, as he also appealed to nature. The ambiguity of Scripture (de resurr. 40.1), its silences, force Tertullian to appeal to other norms. $\mathrm{He}$ demands clarity, definitions, simplicity. He assures Praxeas that the Scripture has no need of his aid to solve its apparent anomalies; it stands, and is imperious (adu. Prax. 18.1) ${ }^{3}$; nonetheless, he has to appeal to the rule of faith (ibid. $2.1 \mathrm{ff}$.), and in the context of that appeal he makes an appeal to the revelation of the Montanist Paraclete. Paradoxically, the desire of Tertullian for clarity, and his latent rationalism drive him towards a non-rational source of certitude, which he found in Montanism. ${ }^{4}$ This revelation would solve all those ambiguities

1 A. D'Alès, ibid., p. 254: 'Tertullien pose en principe que, dans l'interprétation, il faut se conduire d'après la doctrine, connue par ailleurs: mais cette doctrine lui-meme la définit arbitrairement.'

2 Tertullian does not always take so static a view of faith; cf. de bapt. 1.1, for example.

See H. KarpP, op. cit., p. 28; and the comment of O. Kuss, Zur Hermeneutik Tertullians, note 39, p. 146-147.

- Cf. O. Kuss, ibid., p. 157 and note 97 ibid. 
in Scripture which Tertullian had always felt. From his rules on taking the Scripture as a whole, from his attention to historical and stylistic context, Tertullian comes to limit the sense of the scriptures. Using the tools which his wide learning afforded him, he opts for the simpler reading. He shows a certain scepticism in his controversial works, a scepticism which tends to deprive the Scripture of its primacy. A very different attitude is found in his catechetical works; but the rationalism which wishes simple and clear statements finally drives him to take refuge increasingly in non-scriptural norms; in the rule of faith, in tradition, and finally, in the certitude which the Montanist Paraclete offered.

\section{The Background of Tertullian the Exegete}

Like any exegete, Tertullian was already within a commenting tradition. ${ }^{1}$ He cites Irenaeus and Justin, as also Miltiades, et al. (adu. Val. 5.1); he reflects exegeses which were current in his Church (de bapt. 12. 6-7). To the learning of the pagan world, Tertullian is also tributary, though he makes a conventional repudiation of the 'philosophers and poets'. In examining the words which are central in his exegesis, some attention will be paid to those words as used by his predecessors. An important element in the tradition upon which he draws may be noted here; the influence of rabbinic forms of exegesis upon Tertullian. We have already seen some possible examples of this influence. ${ }^{2}$

The $a d u$. Iud. begins with an account of a dispute between a Jewish proselyte, and a Christian. The result did not please Tertullian; his language is characteristic: '..nubilo quodam ueritas obumbratur.' (adu. Iud. 1.1). The non-Jew was able to give a good account of the Law, and Tertullian is able to use this as an argument against his Jewish adversaries. The polemic with the Jews has left many traces in the literature of the time, notably in the Testimonies. ${ }^{3}$ Tertullian makes many comments on the Jews, throughout his works. Although he does not seem to have known Hebrew ( $a d u$. Prax. $5.1 \mathrm{ff}$.), he knows much about their customs; that they salute one another '..in pacis nomine..' (adu. Marc.

1 See: A. Harnack, Tertullians Bibliothek christlicher Schriften, for the sources of Tertullian in this area.

2 Supra, ch. 1, p. 31, note 3, on uirgo; ch. 2, p. 77, exegesis of the storm at sea, with which Tertullian disagrees; ch. 3, p. 129-130, Ps. 1.1 and its interpretation.

a Rendel Harris (with assistance of Vacher Burch), Testimonies, Parts I and II, Cambridge, 1916, 1920; J.-P. AuDET, L'hypothese des testimonia. Remarques autour d'un livre récent, Revue Biblique 70 (1960), p. 381-405. 
5. 5.1), as they did in the Old Testament; characteristic of them is the sapientia scripturarum (ibid. 5. 5.7). Possibly there is evidence of an indirect knowledge of the Hebrew root, when Tertullian comments: 'Iustitiae opus est, quod inter lucem et tenebras separatio pronuntiato est..' (adu. Marc. 2. 12.2). That justice and separation, division are connected here is interesting. As the great dividing point between Jews and Christians, as we have seen, is the Christian belief that the Messias is already come, in that first, humble coming, while the Jews still await him, unaware of the mode of that first coming (apol. 21.15; adu. Marc. 3. 7.1, etc.), so the Christians believe that Christ was speaking through the prophets (adu. Marc. 3. 6.7), and the Jews believe that the prophets were speaking of him (ibid. 3. 5.3).

In the adu. Marc., Tertullian links the teaching of Marcion and that of the Jews (3. 6.2), and accuses the Jews of an overly literal interpretation or their own literature, which misses the deeper significance of it (ibid. 3. 5.2; cf. de resurr. $26.10 \mathrm{ff}$.). The Jewish interpretation of Is. 7. 14, '..ecce uirgo concipiet in utero et pariet flium..' is mentioned, and Tertullian disagrees with the interpretation, iuuencula (adu. Marc. 3. 12.4-5); the chiliastic ideas reflected in adu. Marc. 3. 24.3-6 may reflect Jewish expectations. ${ }^{1}$

It is in the adu. Marc. that we find striking parallels with rabbinic exegeses of difficult scriptural loci. If Marcion used literal Jewish exegesis to show the anomalies within the Old Testament, Tertullian, with his predecessors, used the rabbinical solutions to some of those famous cruces. A recent book has accented the influence of the rabbinic schools on the exegesis of Justin ${ }^{2}$, and Tertullian, dependent on Justin, especially in the third book against Marcion ${ }^{3}$, may have taken some of these rabbinic solutions from him. We are however, in the presence of a widespread source of arguments here.

The apparent ignorance of God, in his question: 'Adam, ubi es' (Gen. 3.9) is a problem to which Tertullian frequently returns. He explains it as a threatening voice (de ieiun. 6.7); it is the voice of the Son, '..quasi nesciens..', taking upon himself all human weakness; Tertullian thus protects the august position of the Father (adu. Prax. 16.4); it is used to explain Luc. 8. 43-48, an affected ignorance which would elicit confession ( $a d u$. Marc. 4. 20.8). The most elaborate treatment of the

$1 \mathrm{~J}$. Dantelou, Les divers sens de l'Écriture dans la tradition chrétienne primitive, ETL 24 (1948), p. 125.

2 Willis Shotwell, The Biblical Exegesis of Fustin Martyr, London, 1965.

3 See G. Qusspel, De Bronnen van Tertullianus' Adversus Marcionem, Leiden, 1943, ch. 4, p. 56-79. Theophilus of Antioch is the probable chief source of the second book of Tertullian adu. Marc.; ibid., p. $34 \mathrm{ff}$. 
problem, however, occurs in adu. Marc. 2. 25.1-3.1 There we find the explanation: 'Nec enim simplici modo, id est interrogatorio sono legendum est: Adam, ubi es? Sed impresso et incusso et imputatiuo: Adam, ubi es! Id est in perditione es, id est iam hic non es, ut et increpandi et dolendi exitus uox sit.'.

The rabbis felt the same difficulty with the text. One explanation plays upon a root in the Hebrew, and reads: 'And the Lord God called unto the man, and said: where art thou? ...how thou hast fallen..'2. Another exegesis reads the text thus: '..i.e., whither is thy heart turned?'3

Another classic problem is the apparent violation of the Sabbath in fosue 6. 3-4. Marcion urged the problem also, and Tertullian answers: 'Arcam uero circumferre neque cotidianum opus uideri potest neque humanum, sed et rarum et sacrosanctum et ex ipso tunc dei praecepto utique diuinum.' (adu. Marc. 2. 21.2). The rabbinic answer is similar: 'If a man should say to you: "how is that Joshua desecrated the Sabbath?" tell him that he did it at the bidding of the Holy One, Blessed is He..'4.

The law against images might seem to have been violated by the order to make the brazen serpent, but Tertullian answers that this was not idolatry, but was intended as a cure for those whom the serpents had bitten (adu. Marc. 2. 22.1 ff.). ${ }^{5}$

Whatever his sources, Justin, Theophilus, and others, Tertullian shows the evidence of certain passing contacts with rabbinical exegesis. ${ }^{6}$ One last, interesting point may be mentioned.

1 G. QuisPeL points out that Tertullian first gives an explanation which is found also in Theophilus, ad Autolycum 2.26; that God was ignorant, uncertain of Adam's whereabouts, is the exposition of Marcion. Tertullian's first answer agrees with that found in Theophilus; this was to give Adam the opportunity to confess (cf. adu. Marc. 4. 20.8). Tertullian follows with a second solution which, found in the rabbis, as noted above, is also in Philo, leg. alleg. 3. 51. Cf. QuisPel, De Bronnen, P. 41-42. These explanations were probably widespread.

2 See: Midrash Rabba, translated under the editorship of Rabbi Dr. J. H. Freedman and Maurige Simon, X Vols., London. 1951; Vol. I, Genesis I (translated by Rabbi Dr. Freedman), London and Bournemouth, 1951 ; Bereshith Genesis XIX. 9 ad Ger. 3.9, p. 155. Cf. also Willis Shotwell, The Biblical Exegesis of Justin Martyr, p. 79.

- See: Babylonian Talmud, translated under the editorship of Rabbi Dr. I. Epstein; Sanhedrin (Nezikin V) (translated by Jacob Shachter and H. Freedman), II Vols., London, 1935, I, p. 244.

- Midrash Rabbah: Vol. VI, Numbers (translated by Judah L. Slotki), II, p. 565-566.

- Cr. Willis Shotwell, op. cit., p. 78.

- Tertullian interprets the sleep of Adam as a prophetic state, ecstasis; The Midrash Rabba, however, (17.5), would have it that this was the sleep of torpor, and not of prophecy.

In many of his exegeses, Tertullian was doubtless dependent on Justin, and we cannot control his dependance on Theophilus' book against Marcion. But these were probably a general possession at the time. 
As has been said ${ }^{1}$, Tertullian vindicates two peculiar features of prophetic utterance. The second of these has been seen, in the theoretic defense of allegory (adu. Marc. 3. 5.3); the first, a view of prophetic time: '..qua futura interdum pro iam transactis enuntiantur. Nam et diuinitati competit quaecumque decreuerit ut perfecta reputare, quia non sit apud illam differentia temporis... (adu. Marc. 3. 5.2). We find this view also in apologeticum: 'Unum tempus est diuinationi futura praefanti...' (apol. 20. 5: cf. also 19. 9, fragm. Fuld.). Citing the prophecy of Is.63.1-3, Tertullian implicitly refers to this view of prophetic time: 'Spiritus enim propheticus, uelut iam contemplabundus dominum ad passionem uenientem...' (adu. Marc. 4. 40.6).

The theory is cited by predecessors of Tertullian. Justin knows of $\mathrm{it}^{2}$, as does Tatian ${ }^{3}$, and a later text cites Tertullian, and the explanation from the adu. Marc. which has just been seen". The teaching would seem to be rooted in Jewish sources. ${ }^{5}$

This brief introduction to the broad lines of Tertullian's exegesis is intended as prelimary to the examination of some of the chief words in his technical vocabulary of exegesis. Tertullian comes to his task of exegete with all the considerable learning which marks him. One can begin, therefore, by noting his frequent use of vocabulary taken from rhetoric.

\section{SOME WORDS FROM RHETORIC}

Tertullian's training is clear in the tight organization of his every treatise. He is most often explained from the juridical vocabulary and approach which is manifest in him. ${ }^{\circ}$ However, legal and rhetorical training covered much the same ground, and his rhetorical training enabled Tertullian to analyse difficult passages from that point of view. An excellent example is found in adu. Marc. 4. 12.5:

1 supra, p. 127.

2 Justin, apol. 42 ; dial. 114, where Justin poses two principles, the one appealing to Rom. 5. 14, the type of the future, the other to 'prophetic' time. Tertullian is more systematic in his enuntiation of the two principles.

3 See: R. M. Grant, Tation and the Bible, Studia Patristica I, p. 297-306, p. 298.

- ecl. ex prophetis, PG-L 5 col. 1330, no. 9, quoting Pantaenus, then Tertullian.

- Cf., in general, ThorleIf Boman, Das Hebräische Denken im Vergleich mit dem Griechischen, Göttingen, 1954, p. 122-123; also, DAvid DAUBE, Two Haggadic Principles and the Gospels, JTS 44 (1943), p. 149-155; explaining a principle which is very much like that invoked by the writer of the ecl. ex prophetis cited supra.

- Cf. A. BECK, Der Einfluss der römischen Rechtslehre auf die Formulierung des Katholischen Dogmas bei Tertullian, Heidelberg, 1923; Römisches Recht bei Tertullian und Cyprian. Eine Studie zur frühen Kirchenrechtsgeschichte (Schriften der Königsberger gelehrten Gesellschaft 7. 2), Halle, 1930. 
Esurierant discipuli ea die, spicas decerptas manibus effrixerant, cibum operati ferias ruperant. Excusat illos Christus et reus est sabbati laesi; accusant Pharisaei. Marcion captat statum controuersiae quasi - ut aliquid ludam cum mei domini ueritate - 'scripti et uoluntatis'. De scriptura enim sumitur creatoris et de Christi uoluntate color, quasi...de exemplo David, introgressi sabbatis templum et operati cibum audenter fractis panibus propositionis.

This passage has been cited by F. C. Colson ${ }^{1}$ as an example of rhetorical criticism. There are many interesting features to it. Marcion cited the case of Luc. 6. 1-5 as a clear example of Christ's teaching breaking with that of the Old Testament. Tertullian represents Marcion as taking his stand on the rhetorical division of questions, citing as status controuersiae a case of written law and the will of the legislator, scriptum et uoluntas. ${ }^{2}$ Against the clear law and will of the Creator, Marcion would adduce the opposed will of Christ; hence an antithesis between the scriptures of the creator, and his own teaching. Tertullian shows that the will of the creator is in accord with that of Christ, because even in the Old Testament, fasting on the sabbath was not permitted (adu. Marc. 4. 12.6-8). Indeed, had Christ ordered the disciples to fast on the Sabbath he would then have been in conflict with the will of the Old Testament legislator (ibid. 7).

One may not be wholly satisfied with the solution of Tertullian. In all events, what is interesting is to see how he turns to his own training in rhetoric-law ${ }^{3}$ to solve the anomaly, where, previously, he appealed, with his predecessors, to rabbinic exegesis to escape apparent anomalies within the Old Testament itself. The rabbis can offer him no help here. Tertullian deprecates his appeal to rhetoric with the phrase: '..ut aliquid ludam cum mei domini ueritate..' (ibid. 5), much as he excuses himself in de resurr. 5.1 : 'Ita nos rhetoricari quoque prouocant haeretici, sicut etiam philosophari philosophi.' There, in the de resurr. it is a question of persuasion. That Christian complex towards the learning of the pagan world, noticed above 4 , is present in these disclaimers. Tertullian attacks the problem ex professo in the de idol., and he concedes that pagan studies are necessary; the Christians may learn, but not teach ${ }^{5}$ : 'Quomodo repudiamus saecularia studia, sine quibus diuina non possunt?' (de idol.10.4).

1 F. C. Colson, Two Examples of Literary and Rhetorical Criticism in the Fathers, JTS 25 (1924), p. 364-377.

' In adu. Marc. 4. 16.5, we find the terminology reflected: 'voluntas legis' (Note also voluntas et factum in adu. Marc. 4. 16.13-15; de paenit. 3. 9).

- Cf. F. C. Colson, art. cit., p. $375 \mathrm{ff}$.

4 supra. p. 126.

- See C. N. Cochrane, Christianity and Classical Culture, Oxford, 1940; New York, 1957, ch. 6, p. $213 \mathrm{ff}$, and passim. 
It is evident that Tertullian brought all his considerable learning to bear on the interpretation of Scripture. In the passage which we have just seen, we find the word color. A difficulty in the text tradition here in the adu. Marc. citation makes the coherence of the sentence difficult to grasp. The word is clear enough. Color ${ }^{1}$ is that artful disposition of evidence which presents a specious case. So Tertullian uses it of the argument of Marcion. We find the word a few times elsewhere; against the arguments from Scripture, nature, and discipline, Tertullian asks: 'Cui ex his consuetudo opinionis prodest, uel qui diuersae sententiae color?' (de uirg. uel. 16.1). The verb in this sense is found: '...mentitis argumentationibus colorare.' (ad nat. 2. 12.22), as also: 'Hanc primam umbram, plane sine lumine, pessimis pictor ille argumentationibus colorauit.' (adu. Hermog. 2.1). Tertullian amuses himself here with a pun, which finds its base in the constant references to Hermogenes as painter, and in the rhetorical use of the words. Thus, later in the tract: '..Hermogenes inter colores suos ...'2 Still using the text from adu. Marc. 4. 12.5 as a departure point, we find the terminology statum controuersiae. Controuersia is a quite general term; but we do find, as preliminary to that discussion of the two special qualities of Scripture, allegory, and prophetic time, what is clearly presented as a definition of terms (adu. Marc. 3. 5.1 ff.), and when he has finished exposing the two points which he wished to make, Tertullian reminds the reader: '..non retractetur de forma scripturae, sed de statu causae.' (ibid. 3. 5.6). One may also observe here that that language which presents controversy as combat, ${ }^{3}$ and of which an excellent example is found in the opening lines of 3.5.1, belongs also to a rhetorical tradition. Such terminology abounds in Tertullian, who composes his treatises tautly, and in closely reasoned fashion; his rhetorical training is everywhere evident. What interests us here, however, is how he applies this literary and rhetorical training to the interpretation of Scripture. It is interesting to note, for example that clausula, which may have a rhetorical, or a legal resonance - the rhetorical seems the more likely in the uses here noted - is used in function of Tertullian's concern for the stylistic context of scriptural utterances (de orat. 8.6; ad uxor. 2. 2.3; adu. Marc. 5. 7.14; 5. 11.11; 11.12; 14.14; de resurr. 30.10; 43.9; 44.10 ; de idol. 4.4 ; de pudic. $8.8 ; 14.13 ; 19.27$ ). The same purpose is served with the constantly recurring cohaerentia, which, while not a

1 Cf. Quintilian, de inst. or. 4.2.88: 'Sunt quaedam et falsae expositiones....alterum, quad est tuendum dicentis ingenio, id interim ad solam uerecundiam pertinet, inde etiam mihi uidetur dici color, interim ad quaestionem.' See also 6.5 .5 ; etc.

2 ThLL III, col. 1713-1722; J. H. Waszink, Tertullian: The Treatise against Hermogenes (ACW no. 24), Westminster, London, 1956, note 286, p. 154.

supra, ch. 2, p. 108-109. 
technical term, is almost always applied, in this participial form, to the stylistic context of Scripture (adu. Marc. 3. 12.2; 4. 34.10; 5.16.1; 17.12; de resurr. 46.1; adu. Iud. 9.2).

Eleganter is applied to the scriptures, and their way of speaking, in all but one use (ad nat. 2. 12.17). It is usually employed to explain, and praise expressions which are peculiarly scriptural ${ }^{1}$; so far is Tertullian, one must repeat, from criticising the style of the Bible (see: de orat. 6.1 ; adu. Marc. 4. 11.8; adu. Marc. 4. 18.7; 5. 8.5; de resurr. 41.3). The word hyperbaton is used once: '..quasi turbate enim per hyperbaton struxit..' (de resurr. 43.7), says Tertullian of 2 Cor. 5.10, and he then asks his adversary how he reads the sentence. ${ }^{2}$ Interpretatio, interpretari, central words, naturally, in Tertullian's exegesis, are made specific by the context. At times, it is clearly a question of translation (ad nat. 1. 8.3; adu. Marc. 4. 14.1; de idol. 3.4); occasionally, it is a question of an etymological explanation (apol. 3.5; adu. Marc. 3. 12.2) most of the time, obviously, the words are used in a hermeneutical sense.

Tertullian is alive to the subtleties of language. He appeals to the ordinary way in which people speak (adu. Marc. 5. 5.7) to explain a passage; he insists on the way in which a passage is read, on how it is stressed (ad uxor. 2. 2.5; adu. Marc. 2. 25.2). This stress in reading is important for interpretation, and Tertullian disputes over the reading of two curiously similar sentences, from Luc. 20. 35 (adu. Marc. 4. 38.79), and 2. Cor. 4. 4 (adu. Marc. 5. 11.9-10). In the last mentioned passage, Tertullian is characteristically troubled by the ambiguity to which Scripture is sometimes open by the manner in which it is enuntiated; and, after a tortured reading, he retires, again characteristically, to a firmer argument: 'Simpliciori responsu prae manu erit...' (ibid., 11).

Other examples might easily be added; Tertullian comes to his task of interpreting the Scripture with excellent equipment. He rightly saw the necessity of pagan studies for the proper understanding of the Bible, and his own use of them is always evident. This glance at some of the traces of his rhetorical-literary formation in his approach to the Bible is intended as preface to the study of five key words in his exegesis, variations in them, and words constantly used in context with them. There are traces of that same formation to be seen there also; but, in at least some words, the biblical origin and field of meaning is dominant. Here again, we will see that meeting of the two sources, the classical and the biblical.

1 supra, ch. 1, p. 28.

2 Cf. Irenaeus, adu. haer. 3. 7.1, of 2 Cor. 4. 4; Quintilian, de inst. or. 8. 6.62; 9. 1.6; 9. 3.91. 
In treating aenigma, allegoria, figura, portendere, and simplicitas, each word will be examined, with a view of its history before Tertullian, and its use by him in certain contexts, and accompanied by other words.

In treating these words, and those associated with them, the primary interest is on their use in Tertullian. Some repetitions from one group to another are unavoidable.

\section{Aenigma}

While hardly central in Tertullian, it is useful to see how he uses aenigma, a word which belongs to the vocabulary of exegesis. ${ }^{1}$ Occurring in classical Greek from the time of Pindar and Aeschylus in the sense of riddle, aivı $\mu a$ is later used for the incomprehensible element in religious expression, and is applied to the oracular and prophetic utterances. $^{2}$

We find it also in the language of grammar and rhetoric. Trypho, a Greek grammarian says of it: '...a form of expression arranged with the wrongful purpose of concealing the meaning in unclarity, or setting forth something impossible or impracticable.' 3 In Latin rhetorical writing, Cicero mentions aenigma in the sense of riddle ${ }^{4}$; more interestinly, when speaking of metaphor and other figured language, he stresses the element of obscurity in the word. ${ }^{5}$ And so Quintilian, too; usually with a certain disapproval, he associates it with allegory, and generally speaks of aenigma disparagingly, as being obscure. ${ }^{6}$ The grammarians speak of it also with disapproval. ${ }^{7}$

In the Bible: Num. 12.8, of God's promise to speak to Moses directly:

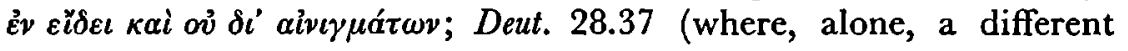
Hebrew word is found in the original text), of the maledictions of Moses on the people; if they disobeyed the Law, they would become

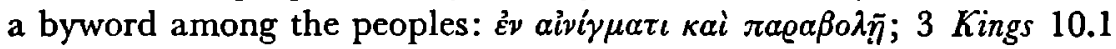
(// 2 Chron. (Paral.) 9.1), of the Queen of Saba, come to try Solomon in riddles. In the Wisdom literature, Prov. 1.6, Wisdom 8.8, in the sense of solving puzzles; Sirach associates it with $\pi \alpha \varrho \alpha \beta o \lambda \eta^{\prime}$ : Sir. 39.3:

1 Cf. R. M. Grant, The Letter and the Spirit, London, 1957, Appendix II, 'Greek Exegetical Vocabulary', p. 120-142; p. 120-121.

2 Gerhard Krttel, TWzNT I, 177 (Kittel).

3rypho, quoted by R. M. Grant, op. cit., p. 120, from Rhet. graec. 3. 193.14.

- ad Att. 7. 13.5-6.

5 de orat. 3 (42) 167.

- de inst. or. 6. 3.50-51;98-99; 8.6.14: (continuous use of figured language '...in allegorias et aenigmata exit.') ; 8. 6.52-53: 'Sed allegoria, quae est obscurior, aenigma dicitur; uitium meo quidem iudicio..'.

7 ThLL I, cols. 985-986. 


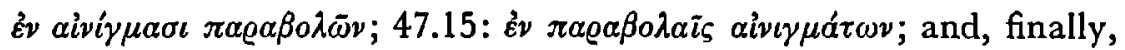
in Dan. 8.23 (LXX), again in the sense of to solve riddles. In the New

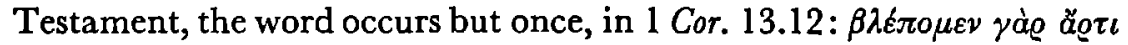

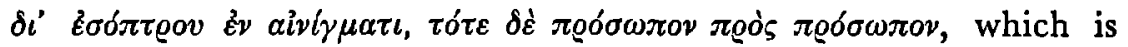
much like the usage in $\mathrm{Num}$. 12.8.1

Not used in the Apostolic Fathers, ${ }^{2}$ Irenaeus uses the word with fair frequency. He denies the ambiguity of the scriptures, against heretics who urged that parabolae, quaestiones, aenigmata were present there ${ }^{3}$; for Irenaeus, Scripture is '..in aperto, et sine ambiguitate..'; some have though to seek out God '...per tenebrosas parabolarum absolutiones...' .4 They have separated God, and the Father. Jesus preached the Father secretly, to those able to understand, they allege, expressing his teaching '..per argumenta, et aenigmata, et parabolas... ${ }^{5}$ Irenaeus, therefore, associates parabola and aenigma, and they connote obscurity. ${ }^{\circ}$ Once, aenigmata et ambiguitates is used of prophecy, which remains so to men, until its realization. ${ }^{7}$ Irenaeus cites 1 Cor. 13.12 once, using the word, to describe the present situation of the orthodox believer. ${ }^{8}$

Looking at Tertullian's uses of aenigma ${ }^{9}$, one may conveniently begin with his constant use of the word in the adu. Prax., departing from 1 Cor. 13.12, and, especially, from Num. 12.8. This is a non-exegetical use, therefore; yet, not without relation to its use applied to the interpretation of the Bible.

In $a d u$. Prax. 14.6 we find typically glossing explanations by Tertullian:

..non quomodo Moysi: Os ad os loquar illi, in specie, id est in ueritate, et non in aenigmate, id est non in imagine, sicut et apostolus: Nunc uidemus tanquam per speculum in aenigmate, tunc autem facie ad faciem.

Tertullian here puts 1 Cor. 13.12 in parallel with $\mathrm{Num}$. 12.8. His dense argument is that God is invisible, and yet was seen by the men of the Old Testament; hence, the Father is invisible, and it is the Son who spoke to the patriarchs, albeit '..in speculo et aenigmate et uisione et somnio... (adu. Prax. 14.7 and passim). The promise made to Moses was fulfilled on Tabor. The repeated use of aenigma, in parallel with uisio, somnium, speculum, up to chapter 16 depends on these texts, and is used

1 Cf. TWzNT I, 177 (Kittel).

2 Among the Apologists, only Justin, who uses the verb: Dial. 5. 4; 76. 1.

adu. haer. 2.9.1.

ibid. 2. 40.2. s ibid. 2. 40.3. 'ibid. 3.5.1.

7ibid. 4. 40.1. B ibid. 4. 19.1.

- For convenience, the complete occurrences of aenigma in Tertullian: adu. Marc. 3. 5.3 ; 4. 22.15; 4. 25.1; 4. 35.14; 5. 6.1; 5. 6.5; 5. 18.14; de resurr. 18.1 ; 20.6; scorp. 11.4 ; adu. Prax. $14.6(2 \times) ; 14.7 ; 14.8 ; 14.9 ; 15.4 ; 16.3 ; 16.6$. 
by Tertullian to show the (dim) presence of the visible Son in the Old Testament, thus providing him with an argument in this Trinitarian discussion. The element of obscurity in the word is clear; yet, here, it is not an unfavorably regarded obscurity; and the biblical word is used to explain biblical texts. In adu. Marc. 4. 22.15, Num. 12.8 is cited, with use of aenigma by Tertullian, in a non-exegetical way, where again, the presence of the Son in the Old Testament is drawn from it, though in a slightly different way.

When used in the explanation of Scripture, or of scriptural ways of expressions, aenigma is used only once alone, and without insistence by Tertullian on the element of obscurity. Explaining the Stone which imaged the two comings of Christ, the first in rejection, the second in glory, Tertullian uses aenigma simply: '.. in lapidis aenigmate...' (adu. Mar. 4. 35.14, referring to Ps. 117.22-23). In all other uses of aenigma, Tertullian puts it in parallel with other words; and, while he is by no means contemptuous of it, the connotation of obscurity is always present. In his theoretical defense of the prophetic mode of speech, he explains, after prophetic time, the special nature of biblical utterances, that is, their deeper meaning. 'Alia species erit, qua pleraque figurate portenduntur per aenigmata et allegorias et parabolas, aliter intelligenda quam scripta sunt.' (adu. Marc. 3. 5.3). In this dense text, Tertullian uses five words to express the deeper sense of Scripture; we miss only simplicitas of the five words which form the line of inquiry of this chapter.

Aenigma, with the exception noted above (adu. Marc. 4. 35.14) never stands alone, as a technical word of exegesis; and, with that same exception, it is not really operative through Tertullian's work. When we find a dense text, which seems to distinguish various forms of revelations in the Old Testament, it is rather likely that Tertullian intends no real distinctions in his terms: '..non prophetias, non parabolas, non uisiones, non ulla rerum uel uerborum aut nominum argumenta per allegorias et figuras uel aenigmatum nebulas obumbrata?' (adu. Marc. 4. 25.1). Here, Tertullian is urging as a difficulty against Marcion: how can Marcion's Christ thank the god of Marcion, who never put anything forward in which the hidden was present; this may account for the obumbrata. Yet this note of obscurity, as will be seen, returns repeatedly in the contexts of aenigma and allegoria. We find the grouping of aenigma, allegoria, and figura in adu. Marc. 5. 6.1; 5. 6.5; a different combination in 5. 18.14, where we find: '...Et quale erit, ut ambiguitatibus et per aenigmata nescio quae creatorem taxaret.....'.This is meant of thelanguage of Eph.6.12, where, according to Marcion, Paul refers covertly to the creator of the world. Tertullian opposes to this the directness of Paul's own speech generally. 
A second group of texts with aenigma is found in the de resurr. As we will see, when treating of allegoria and related words, the problematic here is different. But we find similar texts: figura and aenigma together in de resurr. 19.1; in de resurr. 20.6: 'Quae hic figurae apud Esaiam, quae imagines apud David, quae aenigmata apud Hieremiam, ne uirtutes quidem eius per parabolas profatos?"

Finally, we find a text in scorp. 11.4, which, while using a familiar group, is interesting in that it is said of New Testament texts: 'Haec si non ita accipiuntur, quemadmodum pronuntiantur, sine dubio praeter quam sonant sapiunt, et aliud in uocibus erit, aliud in sensibus, ut allegoriae, ut parabolae, $u t$ aenigmata.' Tertullian rejects such a reading of the New Testament texts, dealing with martyrdom, which he cited just previous to this; for these texts are verified by the actual happenings of the present. This is an implicit appeal to an interpretation principle which has already been announced in adu. Marc. 3. 5.3, and to which we will have to return.

The first remark to make, then, on aenigma in Tertullian, is that it appears only once alone, as a term of exegesis; elsewhere it is put in parallel with figura, allegoria, parabola, imago, uisio. Secondly, one may note that all these texts occur in the adu. Marc., and the de resurr. - the scorp. text alone excepted. It is just in the first two works that Tertullian is concerned with the defense of allegory (in the adu. Marc.); with its defense, and its proper usage (in the de resurr.). The element of obscurity which the texts suggest is to be seen in the context of the controversies with which Tertullian is occupied.

Tertullian seems to be the first to use all these terms together. As has been seen, Irenaeus, doubtless influenced by the Old Testament texts cited above, uses the pairing parabola and aenigma ${ }^{1}$, usually in a pejorative sense. He also uses parabola and allegoria, again, with disapproval. Tertullian does not seem to intend to make a clear distinction between all these words, and it may have been natural for him to add figura and allegoria from rhetorical associations. But the radical inspiration of aenigma, figura, and parabola is biblical. Finally, these uses of parabola, in context with aenigma, allegoria, figura, etc. are very different from the normal use, which is elsewhere related to New Testament parables.

Aenigma, then, appears almost always with other, virtually synonymous terms; refers generally to the latent revelation of the Old Testament, and therefore has an element of obscurity. This obscurity, however, is much less than that which we find attached to aenigma in Irenaeus. It is significant that it is found just in those places when 1 See texts cited, supra, p. 142. 
Tertullian is at pains to defend 'allegorical' interpretation; justifying it against the literalist Marcion, justifying it, and limiting its use against the adversaries of the de resurr. For all its rhetorical resonances, it is probable that Tertullian uses it, through Irenaeus, under biblical inspiration. ${ }^{1}$

\section{Allegoria}

The literature on the problem of allegorical interpretation, its Hellenistic roots, Jewish use of it, and finally, the use made of it by Christians, is extremely abundant. ${ }^{2}$ While remaining outside of this debate, notably the question of the origin and inspiration of Christian allegorical interpretation, this study of the word allegoria, its derivatives, and related words in Tertullian is of interest for the discussion. Tertullian, for all his reserve towards allegory, is certainly a linguistic innovator, and, to a lesser extent, an innovator in the application of allegory to the scriptures.

The Greek verb, $\dot{a} \lambda \lambda \eta \gamma$ ogeiv, is found in Philo and Josephus; the substantive, $a \lambda \lambda \eta \gamma o g i a$ is found in Greek rhetorical writing from the first century B.C. ${ }^{3}$, and we find it, for the first time, in Cicero ${ }^{4}$, still written in Greek, and in his Greek contemporary, Philodemus ${ }^{5}$. Adjectival and adverbial forms are found later, in the first century A.D. In Latin, allegoria is found frequently in Quintilian. As noted above, he links allegoria with aenigma; as continuous use of figurative language, he says, '..in allegorias et aenigmata exit. ${ }^{\prime 8}$; aenigma is an obscurer form of allegoria. ${ }^{7}$

In the Bible, we find only $2 \lambda \lambda \eta \gamma o \varrho \varepsilon i v$, and that but once: in Gal. 4.24. No form of the word is found in the Apostolic Fathers; in the Apolo-

1 Tertullian does not seem to quote any of the Old Testament texts where denigma occurs, with the exception of Num. 12.8.

2 See: W. DEN Boer, De allegorese in het werk van Clemens Alexandrinus, Leiden, 1940; J. C. Joosen and J. H. WAszink, Allegorese, in: Reallexikon fur Antike und Christentum I (1950), 283-293; HeNr De LuBAc, Histoire et l'Esprit. L'intelligence de l'Ecriture d'apress Origène (Théologie 16), Paris, 1950; JEAN PÉPIN, Mythe et allegorie. Lesorigines grecques et les contestations judéo-chrétiennes, Paris, 1958; R. P. C. Hanson, Allegory and Event, London, 1959; HeNRI DE LUBAC, Exégese médiévale: les quatre sens de l'Écriture (Théologie, 41, 42, 59), Paris, 1959-1963.

TWzNT I, 260-264 (Büchsel); R. M. GraNt, The Letter and the Spirit, p. 122-123.

- de orat. 94: '..iam cum fluxerunt continuae plures tralationes, alia plane fit oratio; itaque

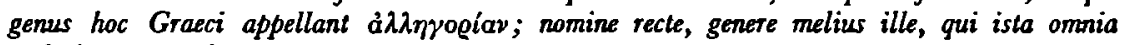
tralationes uocat.'

- See R. M. Grant, op. cit., p. 122.

de inst. or. 8. 6.14 (see note, supra, p. 25).

7 ibid. 8. 5.62-53. 
gists, we find the verb and substantive in Tatian, oratio ad Graecos 21.2, 3 , where it used of the interpretation of Homer by the Greeks; in Aristides, apol. 13.7, the adjective, describing the Greek treatment of myths.

Justin is problematic. In his works as we have them, no form of the word is to be found. But Irenaeus quotes Justin, in adu. haer. 5. 26.3 as using the word. The Latin version: 'Bene Justinus dixit, quoniam ante Domini aduentum nunquam ausus est Satanas blasphemare Deum, quippe nondum sciens suam damnationem: quoniam et in parabolis, et allegoriss, a prophetis de eo sic dictum est.' The text in Greek, then, offers the pairing ' .... $\pi \alpha \varrho \alpha \beta 0 \lambda \tilde{\omega} \nu$ $\kappa \alpha i$ a $\lambda \lambda \eta \gamma \circ \varrho \iota \tilde{\omega} \nu$, as being the words of Justin, from a work of which we know nothing. But this citation may be regarded with some doubt. ${ }^{1}$

Irenaeus uses allegoria (one may assume that the Latin version reflects the Greek $\alpha \lambda \lambda \eta \gamma$ oi $\alpha$, where we no longer have the Greek) and related forms. For allegoria; we find it paired with parabola, explaining the nature of the Old Testament. He says once that the fact that the Old Testament so speaks gives the Gnostics opportunities for their interpretations; (adu. haer. 1. 1.6); later, reacting against a peculiarly literal form of interpretation of Old Testament prophecy, Irenaeus comments on the allegorical nature of prophecies: 'Quna entm prophetae in parabolis et allegorns, et non secundum sonum ipsarum dictionum plurima dixerunt, et ipsi confitentur.' (adu. haer. 2. 32.6). He uses the verb form (where, again, a $\lambda \lambda \eta$ yoeєiv may be supposed to have been in the Greek) three times with disapproval of an interpretation which would not respect the biblical text: adu. haer. 3. 12.14, of Paul's text; 5. 35.1, of the mutually inconsistent efforts of some to allegorise away the promises of earthly goods. They will come after the restitution of the new Jerusalem, and Irenaeus then uses the verb form for the second time, in a remarkable context: 'Et hulus tabernacult typum accepit Moyses in monte, et nihl allegornzari potest' (adu. haer. 5. 35.2). Finally, the adverb, used in a context where the resurrection is being discussed: '...sic et uere resurgit homo a mortuns, et non allegorice, quemadmodum per tanta ostendimus...' (adu. haer. 5. 26.2).

Allegorical interpretation was practiced before the word itself was used $;^{2}$ and similarly, nothing of the interpretation of the Bible ${ }^{3}$ by Tertullian's predecessors is proven by the minor role which allegoria

1 See R. M. Grant, op. cut., p. 122-123.

a Cf. TWzNT I, 162 (Buchsel).

3 For a brief review of exegesis, see G. Bardy, Exégèse palrzshque (section 2 of article, Histoure de l'znterprétatzon), Dictoonnaire de la Bible, Supplément 4 (1949), $569 \mathrm{ff}$; R M Grant, The Letter and the Spirtt, cf. also W. Den Boer, Hermeneutic Problems in Early Christian Literahure, VC 1 (1947), P 150-167. 
and related words play in them. ${ }^{1}$ Coming to Tertullian, we may first note the forms which he uses, and then treat his use of them, proceeding by works. This method has its advantages; Tertullian's concerns vary, from work to work, with important results for his use of words. Tertullian, then uses allegoria, and in its use he is preceded, in Latin, by Quintilian, as far as the word itself is concerned; he is the first to use the adjectival form, allegoricus, etc. ${ }^{2}$; he is also the first to use the adverb, allegorice $^{3}$; and, finally, taking Irenaeus latinus as being later than Tertullian, he is the first also to use the verb: allegorizare. ${ }^{4}$

In his use of these words, we may note, first of all, the two uses where Tertullian comments on the pagan use of allegorical interpretation. The first is found in ad nat. 2. 12.17, where, as we have seen, Tertullian criticises the allegorical explanation of the Saturnus myth: 'Sed eleganter quidam sibi uidentur physiologice per allegoricam argumentationem de Saturno interpretari tempus esse......$^{5}$ Again, in adu. Val. 1.3, we find: 'Sed naturae uenerandum nomen allegorica dispositio praetendens patrocinio coactae figurae sacrilegium obscurat et conuiuium falsis simulacris excusat.' It is of note that Tertullian goes on to complain: 'Si subtiliter temptes, per ambiguitates bilingues communem fidem adfirmant.' (1.4). These texts, showing a certain relationship, show Tertullian's knowledge and disapproval of allegorical interpretation, applied to myths, and used in the syncretistic explanations of the Valentinians. A third, non-scriptural usage is found in the de pudic. 8.11: 'Meminimus enim et histriones, cum allegoricos getus adcommodant canticis, alia longe a praesenti et fabula et scaena et persona et tamen congruentissime exprimentes. Sed uiderit ingenium extraordinarium. Nihil enim ad Andromacham.' This text, however, has a closer relation to the interpretation of the Bible; Tertullian has just finished demonstrating that the parable of the prodigal has nothing to do with the forgiveness of sins; with this comparison with miming actors, he admires the ingenuity of other interpretations, but claims that they are not ad rem.

It is in the adu. Marc. and the de resurr. that Tertullian is most occu-

1 See Paul Heintsch, Der Einfluss Philos auf die älteste christliche Exegese (Barnabas, Justin und Clemens von Alexandria), Münster i. W. 1908 (Alttestamentliche Abhandlungen, Heft $1 / 2$ ), esp. p. $30-41$.

2 ThLL I, 1671-1672. For convenience, the complete occurrences of allegoricus in Tertullian: ad nat. 2. 12.17; adu. Marc. 3. 14.5; 3.14 .7 (// adu. Iud. 9.20); 3. 17.2; 3. 24.2 ; 5. 4.8; 5. 7.11 ; adu. Val. 1.3 ; de resurr. 19.2 ; 20.9; $26.1 ; 29.1$; de pudic. 8.11 . 3 ThLL I, 1672. In Tertullian, allegorice is found: adu. Marc. 3. 5.4; 4. 20.4; de resurr. 27.4 (where Gelenius reads allegorica); de resurr. 31.1 .

- ThLL I, 1672. In Tertullian, allegorizare appears: adu. Marc. 4. 17.12; de resurr. $27.1 ; 30.2$. Irenaeus: adu. haer. $3.12 .14 ; 5.35 .1,2$.

allegoria in Tertullian: adu. Marc. $3.5 .3 ; 4.25 .1 ; 5.4 .8 ; 5.6 .1 ; 5.6 .5 ; 5.18 .5$; de anim. 35.2 ; de resurr. $20.7 ; 28.5 ; 30.1 ; 37.4$; scorp. 11.4 ; adu. Prax. 13.4.

5 See the comment of J. PÉPIN, Mythe et allegorie, p. 365-367. 
pied with allegorical interpretation, and the principles which should govern its use. These works should be examined, then, and finally, the few other, casual uses of allegoria and related words.

At the risk of repetition, a central text from the adu. Marc. may be again cited. Tertullian posits two principles of interpretation, as we have seen; that of prophetic time, by which the future is announced as if present, and that of the deeper sense which lies in prophecy, demanding an interpretation that goes farther than the literal meaning. He is preparing the ground of the discussion with Marcion, and whatever his debt to Justin here', Tertullian's language is original, and his explanation more subtle than those of his predecessors. The text (adu. Marc. 3. 5.3-4):

Siue enim Christus iam tunc in semetipsum, secundum nos, siue prophetes de semetipso, secundum Iudaeos, pronuntiabat, nondum tamen factum pro iam transacto sonabat. Alia species erit, qua pleraque figurate portenduntur per aenigmata et allegorias et parabolas, aliter intellegenda quam scripta sunt. Nam et montes legimus destillaturos dulcorem, non tamen, ut sapam de petris aut defrutum de rupibus speres, et terram audimus lacte et melle manantem, 〈non tamen,〉 ut de glebis credas te umquam placentas et Samias coacturum, .....

4. Et quid ego de isto genere amplius? Cum etiam haereticorum apostolus ipsam legem indulgentem bobus terentibus os liberum non de bobus, sed de nobis interpretetur, et petram, potui subministrando comitem, Christum adleget fuisse, docens proinde et Galatas duo argumenta fliorum Abrahae allegorice cucurrisse, et suggerens Ephesiis, quod in primordio de homine praedicatum est, relicturo patrem et matrem et futuris duobus in unam carnem, id se in Christum et ecclesiam agnoscere.

There are many things to say about this text. One notes first that all the words which are central in Tertullian's exegesis are found here, simplicitas and its related words alone excepted. Given the nature of Tertullian's concerns here, all these words are bent on the future fulfilment, and on the relation of the two testaments. Tertullian enuntiates the principle that this sort of interpretation (and he suggests a multitude of words for it, allegorical terminology among them) is to be applied there where what we would call the literal meaning is not possible. Now while the word does not appear, the idea seems to be the same: the absurd is the sign of allegory. ${ }^{2}$ The logical manner of Tertullian is his treatises appears here; he will return to this basic principle many times.

1 Dial. 114, etc.

- See: J. PépIN, $A$ propos de l'histoire de l'exégèse allégorique : l'absurdite, signe de l'allegorie, Studia Patristica I, p. 395-413. 
For the originality of Tertullian here, one may quote Père de Lubac: 'Il suffit.. de lire un certain nombre de textes des deux initiateurs que sont ici Tertullien et Origène pour obtenir la certitude que, mot et idée, l'allégorie chrétienne vient de saint Paul. Si elle a été mise en valeur avec les ressources de la culture héritée des Grecs, nul autre que lui, quant à l'essentiel, ne l'a accréditée.' 1 De Lubac is of the opinion that Jean Pépin ${ }^{2}$ does not fully acknowledge Paul as source of the Christian use of allegorical interpretation. It is not the intention here to enter in on this debate. It does seem a mistake, however, to cite the text from adu. Val. 1.3 as illuminative of Tertullian's uses in the adu. Marc. His intentions in the two works are quite different. ${ }^{3}$ Secondly, we may note that it is precisely the text of Marcion-Paul which permits Tertullian to make his claim to allegorical interpretation. This takes nothing away from Tertullian's linguistic innovations, which are of themselves significant. But it is to be noted that Tertullian appeals to the text of Paul as Marcion himself accepted it, to found the allegorical method. Another aspect is the constant appeal to the principle that allegory is there to be applied where the 'literal' text results in clear 'absurdities'. Tertullian, in the text which has just been cited, notes that Marcion-Paul admits a kind of allegory, in his interpretations: in 1 Cor. 9. 9-10, interpreting Deut. 25.4 as necessarily having a relation to the present; 1 Cor. 10.4, the legend of the stone which accompanied the Israelites through the desert is interpreted as Christ; Gal. 4. 21-31, the Pauline interpretation of Gen. 21. 2-9 as being allegorical of the two testaments, supplies Tertullian with a base in Marcion-Paul for the word; and, finally, Eph. 31-32, interpreting Gen. 2.24 as mysteriously prefiguring the union of Christ with the Church. Tertullian, therefore, does find his immediate inspiration in Paul; but it is just the text of Marcion-Paul upon which he seizes, and which permits him to use this terminology and this interpretation to affirm what Marcion denied: the unity of the two testaments. As always in Tertullian, the context of the argument at hand is necessary for an evaluation of his expressions.

To establish the antinomy between the two testaments, Marcion interpreted the promises of the Old Testament literally. Tertullian quotes him: 'Christus Esaiae Emmanuhel uocari habebit. Dehinc uirtutem sumere Damasci et spolia Samariae aduersus regem Assyrionum.' (adu. Marc. 3. 12.1). But, continues Tertullian, exposing the argument of Marcion,

1 Henri de Lubac, Exégèse médievale, I.2, p. 377.

H. De Lubac, A propos de l'allégorie chrétienne, RSR 47 (1959), p. 5-43; Exégèse médiévale, I. 2, p. 374-396.

S Cf. H. de Lubac, op. cit., I. 2, p. 377. 
he who came was not called by the name Emmanuel, nor did he come armed, as was promised of him. Appealing first of all to the full context, Tertullian comments that Marcion concentrates only on words, and not on their meaning: 'At ego te admonebo, uti cohaerentia quoque utriusque capituli recognoscas. Subiuncta est enim et interpretatio Emmanuhelis: nobiscum deus, uti non solum sonum... spectes sed et sensum.' (ibid. 2). ${ }^{1}$ The appeal which Tertullian makes to the context, containing the explanation of Emmanuel, is not Matth. 1.23 (as the scriptural apparatus of the CC edition suggests), but Is. 8.10, read in the light of Matth. 1. 23-24: $\delta \tau \iota \mu \varepsilon \theta^{\prime} \dot{\eta} \mu \tilde{\omega} \nu$

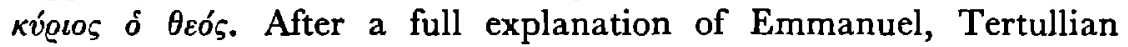
refers to the second Isaian passage used by Marcion, Is. 8.4. 'Aeque sono nominum duceris, cum uirtutem Damasci et spolia Samariae et regem Assyriorum sic accipis, quasi bellatorem portendant Christum creatoris, non animaduertens quid scriptura praemittat: quoniam priusquam cognoscat 〈puer〉 uocare patrem et matrem, accipiet uirtutem Damasci et spolia Samariae aduersus regem Assyriorum.' (adu. Marc. 3. 13.1). First then, the appeal to the full context; then, the clever demonstration by Tertullian that the literal reading, the one pressed by Marcion to show discontinuity between the testaments, itself results in nonsense; how should an infant do all these things? He concludes then: '... sequitur, ut figurata pronuntiatio uideatur.' (ibid. 3).

This, by way of preface to the uses of allegoricus by Tertullian in adu. Marc. 3. 14.5, 7. He cites Ps. 44.4, and puts it in context with the preceding verse; the one announcing the sword of the promised Christ, the other, 'Tempestiuus decore praeter filios hominum, effusa est gratia in labiis tuis.' (3. 14.1). Tertullian again shows the inappropriateness of this, and concludes, from a comparison of this locus with similar imagery in the Apocalypse (19.21), and in Paul, the common master (ibid. 3. 14.4) to a dilemma for Marcion, from out his own Pauline text: 'Si tuus Christus est, ergo et ipse bellator est. Si bellator non est, machaeram intentans allegoricam, licuit ergo et Christo creatoris in psalmo sine bellicis rebus ense sermonis praecingi figurato,..... (adu. Marc. 3. 14.5). The argument is the same; the literal interpretation, both of Old Testament prophecy, and of the text of Paul which Marcion accepts, is impossible; if Marcion must be supposed to admit a certain allegorical interpretation for his own texts, why cannot this also be applied to the Old Testament? Tertullian presses his point: 'Agnosce et spolia figurata, cuius et arma allegorica didicisti. Figurate itaque et domino eiusmodi loquente et apostolo scribente, non temere interpretationibus eius utimur, quarum exempla etiam aduersarii admittunt, atque ita in tantum Esaiae erit Christus qui uenit, in quantum non fuit bellator, ' Cf. scorp. 7.5: 'Verba non sono solo sapiunt, sed et sensu...' 
quia non talis ab Esaia praedicatur.' (ibid. 7). Tertullian returns to Is. 8.4, the text urged by Marcion in so literal a reading, later, using allegoricus: 'Age nunc, qui militarem et armatum bellatorem praedicari putas, non figurate nec allegorice, qui bellum spiritale aduersus spiritales hostes spiritali militia et spiritalibus armis spiritaliter debellaturus esset,..' (adu. Marc. 4. 20.4). Here, Tertullian departs from Luc. $8.26 \mathrm{ff}$, to show that Christ did in fact do battle with 'spiritual' enemies, and this reinforces the interpretation of Is. 8.4. In passing, one may note two layers of meaning in Tertullian's repeated use of spiritalis, spiritaliter. Ps. 44.3-4, important to Tertullian as illustrative of, and confirming his reading of $I s .8 .4$, is found again with allegoricus: '...sed in allegorico illo statu gratiae spiritalis...' (adu. Marc. 3. 17.2; and finally, both texts are cited, to comment upon Marcion's own text of Eph. 4.8, '..captiuam, inquit, duxit captiuitatem.':

Volo nunc et ego tibi de allegoriis apostoli controuersiam nectere, quas non uis in prophetis habursse formas: captiuam, inquit, duxit captiuitatem. Quibus armis? Quibus proeliis?....Nam et cum apud Dauid Christus canitur 'succinctus gladio super femur' aut apud Esaiam 'spolia accipiens Samariae et uirtutem Damasci', uere eum et uisibilem extundis proeliatorem (adu. Marc. 5. 18.5). The lines of the argument are the same. From the Pauline texts which Marcion admits, Tertullian draws the necessity of allegorical interpretation; whence the passage to Old Testament texts is made. If Marcion was a literalist when interpreting the Old Testament, Tertullian obliquely accuses him of using allegory himself, notably in his use of the Lucan text on the good and bad tree and their fruits: which, as has been seen, was a central text for Marcion to mirror the separation between the creator and the God whom Christ revealed; a text also which Tertullian continually alludes to in this context. After citing the text allusively, Tertullian says: 'Mutto enim haec congruentius in ipsos interpretabimur, quae Christus in homines allegorizauit, non in duos deos secundum scandalum Marcionis.' (adu. Marc. 4. 17.12). One may paraphrase the text: We may more properly apply the text of the good tree and ats fruit, the bad tree and its bad fruit to Marcion and Appelles, his follower; a text which Christ used in allegory of men, and which Marcion interprets as meaning two gods. This is the first time that Tertullian uses the verb form, and it is the only time in the adu. Marc. that he does so. Its use here is worthy of comment; for Tertullian applies it to the imaged language of Christ in the New Testament. This is unusual. Largely due to his polemic with Marcion, Tertullian is constantly concerned with the relation of the two testaments; and the great majority of his uses of the terminology allegoria, allegoricus, allegorice in the adu. Marc. is occupied with establishing the relation of the two testaments. In this connection, it is inter- 
esting to note what he says of his now lost work, de spe fidelium: 'Sed de sinu Abrahae suo tempore. De restitutione uero Iudaeae, quam et ipsi Iudaei ita ut describitur sperant ${ }^{1}$, locorum et regionum nominibus inducti, quomodo allegorica interpretatio in Christum et eccleszam et habitum et fructum elus spiritalter competat, et longum est persequi et in alio opere digestum, quod inscribimus 'de spe fidelium'...' (adu. Marc. 3. 24.2). The phrasing with which Tertullian describes his work can be applied to his development of allegory, against Marcion: in Christum et ecclesiam.

As Tertullian insisted in the fourth book, the exclamation of thanks by Christ, even in Marcion-Luke (10.21), 'Gratias enim, inquit, ago et confiteor, domine caeli, quod ea, quae erant abscondita sapientibus et prudentibus, reuelaueris paruulis.' (adu. Marc. 4. 25.1) is unintelligible, unless it be understood of the creator; for the God of Marcion was, ex hypothesi, inactive, a god '..qui omnino nihil praemiserat, in quo aliquid absconditum esse potuisset, non prophetias, non parabolas, non uisiones, non ulla rerum aut uerborum aut nominum argumenta, per allegorias et figuras uel aenigmatum nebulas obumbrata?' (adu. Marc. 4. 25.1). We find here three members, consisting each of three categories of significant, prophetic announcements in the Old Testament, and allegoria is among them. Tertullian does argue from words, from names, and from things; but it would be a mistake to suppose, as has already been noted when dealing with aenigma, that he regards each of these as a clearly defined category. What he is insisting upon is the fact that the Old Testament did in fact contain a shadowy message, which is made clear in the New. Very similar to this argument of Tertullian is the text in adu. Marc. 5.6.1 ff. Departing from 1 Cor. 2. 6-7, he uses terminology which is very like that used in the text noted above, from 4.25.1. 'Hanc sapientiam in occulto fuisse, quae fuerit in stultis et in pusillis et (in) inhonestis, quae latuerit etiam sub figuris, allegoriis et aenigmatibus, reuelanda postmodum in Christo, posito in lumen gentium a creatore promittente per Esaiae uocem....' (5.6.1). Tertullian goes on: 'Non enim eius est festinasse in proponendo, cuius est retardasse in reuelando. Creatori autem competit utrumque: et ante saecula proposuisse et in fine saeculorum reuelasse, quia et quod proposuit et reuelauit medio spatio saeculorum in figuris et aenigmatibus et allegoriis praeministrauit.' (5. 6.5). One may note that reuelare, in $4.25 .1 ; 5.6 .1,5$ is used of the New Testament, over against the suggestions of the Old Testament. Here, Tertullian insists on the continuity between the two; the New Testament texts of Marcion are themselves indicative of a previous, obscure promise of revelation.

1 Cf. de resum. 26.10: 'Sic Iudaei terrena solummodo sperando caelestia amittunt...' Tertullian associated the exegesis of Marcion with that of the Jews in adu. Marc. 3. 8.1. 
We began with theory. The central text from adu. Marc. 4. 5.3 departed from Marcion's own texts of Paul; as also from the impossibility of a literal interpretation of the Old Testament. This notion of impossibility is suggested by Paul himself in his comment on Deut. 25.4, in 1 Cor. 9. 9-10. Just as he appealed to this text, kept by Marcion, when, in 3. 5.4 he partially based his claim to allegorical interpretation on the text of Marcion-Paul, Tertullian comments on the text 1 Cor. 9. 9-10, when he comes to it, in his analysis of the Apostolikon: 'Ergo et legem allegoricam secundum nos probauit et de euangelio uiuentibus patrocinantem, ac propter hoc non alterius esse euangelizatores quam cuius lex, quae prospexit illis, cum dicit : propter nos enim scriptum est.' (adu. Marc. 5. 7.11). Without using the terminology of allegory, he makes a remark here in the fifth book, also, on the interpretation of Marcion's text in 1 Cor. 10.4 (adu. Marc. 5. 7.12). Here we find figura, sacramentum, figurare. Eph. 5. 31-32 appears in adu. Marc. 5. 18.9-10, and, as anticipated in 3. 5.4, is a text which proves the unity of the two testaments for Tertullian: '...in Christum et ecclesiam. Habes interpretationem, non separationem sacramenti. Ostendit figuram 〈sacra〉menti ab eo praeministratam, cuius erat utique sacramentum.' (5.18.10). But it is Gal. 4.24 which, as in his theoretic defense in 3.5.3-4, so also in his commentary on the Marcionite text appears as the central text from the edition of MarcionPaul which seems to have justified Tertullian in the use of the word, and certainly of the method, of allegory in the scriptures. This text has already been seen in the first chapter, as will be remembered. ${ }^{1}$ Marcion changed the text here drastically, interpolating into it a section from Eph. 1. 21, and other, extraneous material. In all events, Tertullian quotes the Marcionite text of Gal. 4. 24, glossing allegorica with portendentia, and then going on to say: '..utique manifestauit et Christianismi generositatem in flio Abrahae ex libera nato allegoriae habere sacramentum, sicut et Iudaismi seruitutem legalem in filio ancillae, atque ita eius dei esse utramque dispositionem, apud quem inuenimus utriusque dispositionis deliniationem.' (5.4.8).

The translation problem here is the more interesting, when one reflects on Tertullian's originality in Latin in the use of allegoricus, as well as other forms. From the text it appears certain that here, at least, Marcion was prepared to accept the text Gal.4. 24, with its allegorical implications, which he thought to turn to the benefit of his argument, by changing the wording of the following sentences.

This analysis of allegoria, and its related words in the adu. Marc. shows that the concerns of Tertullian in his use of allegory, are precisely the concerns of his polemic with Marcion: the unity of the two testa1 supra, p. $55 \mathrm{ff}$. 
ments. They must, therefore, be interpreted in this light. The good controversialist Tertullian bases his claim for allegory in texts of Paul which Marcion, too, accepted. Basic to many of the applications is the principle that allegory is there to be applied where the text itself is otherwise unintelligible; a principle which Tertullian, by appealing to the full context, is able to urge even against the proof texts of Marcion. Allegorical interpretation, one may note, is wider than the use of the words; Tertullian simply takes over, from the tradition of his predecessors, many of the readings of Old Testament texts. What is original is the explicit rooting of allegory in Paul; yet, as has been seen, this must be seen in the context of the adu. Marc.; and Tertullian is the first witness to allegoricus, allegorice, allegorizare. Tertullian does not regard allegory as a category of interpretation sharply distinguished from figura, etc. In the de resurr., we find the second tract where Tertullian makes intensive use of allegoria and its related words. Here, the concerns of Tertullian are very different. An evaluation of the texts here can best be made with Tertullian's problematic clearly in mind. Tertullian has to deal with adversaries who, on the one hand, overdo allegorical interpretation, and yet, whose interpretation is sometimes all too literal. A first group of texts deals with the first problem, that of over-allegorising. Of them, he says: 'Nacti enim quidam solemnissimam eloquii prophetici formam, allegorici et figurati plerumque, non tamen semper, resurrectionem quoque mortuorum manifeste adnuntiatam in imaginariam signifcationem distorquent, adserentes etiam ipsam mortem spiritaliter intelligendam.' (19.2). From the following context, it appears that the adversaries with whom Tertullian here is dealing with Gnostic-tinged Christians (cf. de resurr. 19.6 and adu. Val. 1.4). But everything is not a figura, says Tertullian; otherwise, where is the thing to be found of which they are figures? (20.2). He comments on texts which we have seen, in the adu. Mare., in another light: ' $N a m$ et uirgo concipiet in utero non figurate, et peperit Emmanuelem, nobiscum deum, (Iesum) non oblique, etsi oblique 'accepturum uirtutem Damasci et spolia Samariae', sed manifeste (deum) 'uenturum in iudicium cum presbyteris et archontibus populi'.' (20.3). The figures of the Old Testament are figures, because their reality is found in the New; what else are the figurae, imagines, the aenigmata of Isaias, David and Jeremias, unless the miracles of Jesus, '. .per parabolas profatos?' (20.6). Tertullian goes on: 'Quae et si spiritaliter quoque interpretari solemus secundum conparationem animalium uitiorum a domino remediatorum, cum tamen et carnaliter adimpleta sunt, ostendunt prophetas in utramque speciem praedicasse, saluo eo, quod plures uoces eorum nudae et simplices et ab omni allegoriae nubilo purae defendi possunt...' (20.7). 
We find then the reverse side of the principle enunciated by Tertullian in the $a d u$. Marc., as elsewhere, that allegory is to be applied, when the literal reading results in nonsense. Here, we find Tertullian saying: 'Res in litteris tenentur, litterae in rebus leguntur. Ita non semper nec in omnibus allegorica forma est prophetici eloquii, sed interdum et in quibusdam.' (20.9). A further appeal is made to the whole tenor of the scriptures, judging the uncertain by the certain.

In chs. 26-27, Tertullian comes to the other level of the problem; the over-literalness of his adversaries in certain texts. 'Vnum adhuc respondebo ad propositionem priorem allegoricarum scripturarum, licere et nobis corporalem resurrectionem de patrocinio figurati proinde eloquii prophetici uindicare.' (26.1). The discussion which follows, when Tertullian takes the very weapon of his adversaries, and turns it on them, is interesting only for the application of the familiar principle; if we take Ps. 96. 4-5 (and other texts dealing with terra) literally, it cannot be understood: '.. si simpliciter de terrae elemento utrumque existimabitur pronuntiatum quomodo congruet et concuti et liquefieri eam a facie domini...' (26.4). This argument is appealed to throughout the chapter; in 26.10 , we find an interesting text which criticises the scriptural interpretation of the Jews; it is too literal $(26.10 \mathrm{ff}$.). Whatever the source of Tertullian's own interpretation here ${ }^{1}$, it is certainly very free. The second allegorical development which Tertullian uses against his adversaries is that which appeals to imagery of clothing, throughout Old and New Testaments: 'Habemus etiam uestimentorum in scripturis mentionem ad spem carnis allegorizare...' $(27.1) .^{2}$

Appealing then to things, as well as to words, Tertullian adds other proofs: 'Scimus autem sicut et uocibus ita et rebus prophetatum; tam dictis quam et factis praedicatur resurrectio.' (28.1). Though the terms of allegory do not appear here, it appears that Tertullian regards the argument made from events and facts in the Bible, as well as that from words, as being related to the allegorical ${ }^{3}$; with a clear division, he moves on another category: 'Sunt et quaedam ita pronuntiata, ut allegoriae quidem nubilo careant, nihilominus tamen ipsius simplicitatis suae sitiant interpretationem..' (28.5). Summing up, he says: 'Igitur si et allegoricae scripturae et argumenta rerum et simplices uoces resurrectionem carnis, quamquam sine nominatione ipsius substantiae, obradiant...' (29.1).

Tertullian now cites Ezech. 37. 1-14, and refuses to accept an allegorical interpretation of it (30.1-2), which would make of the vision in the valley of bones nothing more than an image of the reunion of

1 Cf. R. P. C. Hanson, art. cit., JTS n.s. 12 (1961), p. 273.

2 Cf. supra, ch. 2, p. $93 \mathrm{ff}$. $\quad$ Cf. adu. Marc. 4. 25.1 . 
the tribes of Israel. Tertullian's strong sense of realism is nowhere more apparent than in the reading of the vision of Ezechiel. To be a sign, the vision must itself have consistency and reality. If the bones are the image of the reunion of Israel, then they must actually have risen; '..necesse est esse prius sibi id quod alii configuretur.' (30.5). The historical reality of the event is important for Tertullian.

Once last occurrence of allegoria in the de resurr. is found in 37.4. Here it is used of a New Testament saying of Christ: 'Nam et paulo ante carnem suam panem quoque caelestem pronuntiarat, urgens usquequaque per allegoriam necessariorum pabulorum memoriam patrum..' As in adu. Marc. 4. 17.12, Christ is described as having used allegory.

The de resurr. ends (63.7-10) with Tertullian's appeal to the certainty which is brought by the Montanist Paraclete; a certainty which affirms the resurrection clearly, confirming the Scripture: '...et pristina instrumenta manifestis uerborum et sensuum luminibus ab omni ambiguitatis obscuritate purgauit.' (63.7)..$^{1}$ This entire passage illuminates the difficulty which Tertullian sense throughout his scriptural argument in the de resurr., and his feeling towards allegory in this tract. He uses nubilum ${ }^{2}$ twice in the de resurr. of allegory $(20.7 ; 28.5)$; doubtless, it is an index of his uncertainty with allegory here in the de resurr. but not of his 'contempt' for allegory in general. ${ }^{3}$ Ambiguitas, used twice in the closing lines of the de resurr., is frequently used in contexts of scriptural interpretation. ${ }^{4}$

The de resurr., therefore, presents a different view of Tertullian's use of, and attitude towards allegory. His concerns in this tract are very different; in the adu. Marc., he departs from the text of Marcion-Paul, to justify allegory. While obscurity marks allegory in the Old Testament, this is in contrast with the revelation of the New Testament.

1 On the meaning of pristina instrumenta scripturarum (cf. de monog. 4. 1), there are various opinions. Karpp reads such expressions (explicitly of the de monog. text) of the Old Testament; Harnack, of the whole Bible. In this citation from de resurr. 63.7 , it seems clear from the previous arguments of Tertullian that he means the entire Bible, to which then the revelation of the Paraclete comes as explanation and confirmation. See de monog. 14. 3, however, where the Paraclete seems to correct Paul. Cf. O. Kuss, art. cit., note 57, p. 151.

${ }^{2}$ Cf. adu. Iud. 1.1; de anim. 3.3, enubilare. Cf. Apuleius, met. 10.28: '..repente mentis nubilo turbine correpta...' apol. 50 : '..repentino mentis nubilo..'; the successors of Tertullian, notably Jerome, follow him in speaking of the nubilum allegorice. Of many references in Jerome, note: in Hezech. 9. 29.349 (CC LXXV (F. Glorie), p. 412, l. 1).

3 Cf. R. P. C. Hanson, Notes on Tertullian's Interpretation of Scripture, JTS n.s. 12 (1961) p. 275.

de praescr. 14.1; 17.3; adu. Hermog. 37.2; adu. Marc. 2. 14.2; 5. 11.10; 5. 18.14. The frequent use of ambigue, ambiguitas, in adu. Val. is interesting: $1.4 ; 6.1 ; 6.2 ; 12.4$. Cf. ambigue in de resurr. 21.3. 
The de resurr. presents a situation where Tertullian criticises overallegorisation, and uses allegory against his opponents. The problematic is not merely the relation of the two testaments, but the interpretation of the Bible itself. That latent scepticism of Tertullian becomes more evident, and he takes refuge in the non-scriptural argument found in Montanist prophecy.

The adu. Marc. and de resurr. then, with their different problems and attitudes, are the two tracts where the terminology of allegory is most intensively used. In closing, some other, casual uses of the words may be noted.

In de anim. 35.2 allegoria is used of a parable of the New Testament: 'Huc enim temperat totam illam allegoriam domini certis interpretationibus reiucentem et primo quidem simpliciter intelligendam.' Tertullian's characteristic words, connoting clarity, the literal interpretation (though Tertullian's own interpretation, perhaps, is hardly literal) appear here again. Where Irenaeus, handling a similar problem (adu. haer. 1. 20.2)1, used parabola, Tertullian uses allegoria.

In scorp. 11.4, Tertullian has just cited numerous texts from the New Testament commanding the duty of martyrdom (Luc. 14.26; Matth. $10.39 ; 10.19 ; 25.36 ;$ Luc. 18.7). He then comments, citing a principle of interpretation: 'Haec si non ita accipiuntur, quemadmodum pronuntiantur, sine dubio praeter quam sonant sapiunt, et aliud in uocibus erit, aliud in sensibus, ut allegoriae, ut parabolae, ut aenigmata.' Tertullian appeals again to the principle: what the scriptures seem to predict is in fact coming to pass; therefore, such scriptures are to be taken literally (11.4-8). Tertullian disagrees, not with the possibility of an allegorical interpretation of scripture, but with its application to these New Testament texts.

Similar to this is a text from adu. Prax. 13.4. Citing scriptural texts which indicate plurality of persons in the statements dealing with God's actions in the Old Testament, Tertullian confronts his opponent with the choice: 'Haec aut nega scripta, aut quis es ut non putes accipienda quemadmodum scripta sunt, maxime quae non in allegoriis et parabolis sed in definitionibus certis et simplicibus habent sensum?'

This completes a brief vicw of allegorical terminology in Tertullian. He knows that this sort of interpretation is used of myths (ad nat. 2. 12. 17), it was also used in religious interpretation by Gnostic Christians (adu. Val. 1.3 ; de resurr. passim). Tertullian employs it with most confidence in his polemic with Marcion, and in that controversy, he justifies its use from the text of Marcion-Paul, to show the unity of the two testaments. To appreciate his use of allegorical terminology, this ${ }^{2}$ Cf. J. H. WAszrnK, De Anima, p. 410-411. 
distinction should be made; the application of, and attitude to allegory is very different from the one work to the other. His principle, that allegory obtains when the 'literal sense' results in nonsense, has its reverse side: allegory is not present where the Scripture is confirmed by actual events.

\section{Figura}

It is clear that Tertullian's use of aenigma is slight; only once is it used absolutely, without synonyms. Allegoria and related words are found chiefly in the adu. Marc., and de resurr. Figura, and similar words, however, run through the entire work of Tertullian, and it is around this word that his exegesis is built. Here again, he is a linguistic innovator. Both the ThLL article on figura ${ }^{1}$, and an article by E. Auerbach ${ }^{2}$ observe the shift in meaning which occurs, under biblical influence and Christian use, in figura, and its related words. A detailed treatment of figura, etc. is impossible here. It is of interest, however, to note various meanings, and backgrounds of the words. As often in Tertullian's works, we find Christian and non-Christian meanings coexisting. These other meanings are not employed, naturally, in his technical vocabulary of exegesis. A glance at some of them will show the extreme complexity of this word in Tertullian. Beginning then, with figura ${ }^{3}$, we note first some uses of this word in a rhetorical sense, as also of the verb, figurare. Originally used in the sense of a likeness wrought by art, (and the word is closely associated with fingere $)^{4}$, figura developed in Latin under the influence of Greek words like $\sigma \chi \tilde{\eta} \mu \alpha$ and $\tau \dot{v} \pi \varsigma_{\text {s, }}$ as well as

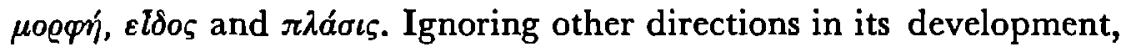
Cicero used figura in a rhetorical way (reflecting the Greek $\sigma \chi \tilde{\eta} \mu \alpha$ ), notably of the three manners in oratory; figura grauis, mediocris, and attenuata. ${ }^{5}$ Between Cicero and Quintilian, a further development

1 ThLL VI. 1, 732; on figurare, ibid. 734.

2 Ertch Aueraach, Figuta, Archivum Romanicum 22 (1938), p. 436-489, p. 450 ff.

3 Figura occurs much too frequently in Tertullian to list all occurrences. Justin and

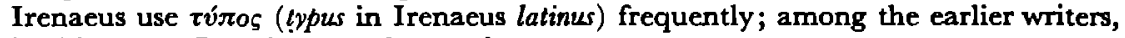
in this sense, Barnabas uses the word.

Tertullian uses exemplum and documentum in a similar way, though far less frequently. Cf. de resurr. 38.5: At ego deum malo decipere non posse, de fallacia solummodo infirmum, ne aliter documenta praemisisse quam rem disposuisse uideatur. Immo si nec exemplum resurrectionis sine carne...ualuit inducere, multo magis plenitudinem exempli sine eadem substantia exhibere non poterit. Cf. 38.2; 58. 9-10: '..cuinam fidei testimonium signant, nisi qua credi oportet haec futurae integritatis esse documenta? 10. Figurae enim nostrae fuerunt apostolo auctore...'; ct. de bapt. 5.5 ; '...exemplum futuri praecucurrit..'. But these words cannot be regarded as exact substitutes for figura.

- E. Auerbach, art. cit., p. 436-437.

b de orat. 3. 199. 
occurred in figura, which made it a technical word for what we also still call figures. And so we find the word often in the eighth and ninth books of Quintilian', although he distinguished between tropoi and figurae. The distinction did not endure long; all figures were soon called figurae. A speech was to be figuratus. Some traces of rhetorical uses of figura and figurare are visible in Tertullian. Like aenigma, and allegoria, figura too has certain relations with rhetoric. But, anticipating, the transformation of this word is far more profound than in the case of the previous two words.

We find typically rhetorical terms in ad nat. 1. 3.8: 'Haec uocabulorum aut nominum crimina, sicuti uerborum atque sermonum barbarismus est uitium et soloecismus et insulsior figura.' Of the joking remark made to Thales: 'Itaque casus eius per figuram philosophos notat....' (ad nat. 2. 4.19). That we should find figura so used (and never in the deeper, biblical meaning) in the ad nat. is unsurprising. But we find rhetorical uses elsewhere. Speaking of the charges made by John the Baptist, against Herod, Tertullian interprets Luc. 16.18 as charges made by Christ against Herod: 'Facta igitur mentione Iohannis dominus, eo utique succensus exitu eius, inlicitorum matrimoniorum et adulterii figuras iaculatus est in Herodem...' (adu. Marc. 4. 34.9). ${ }^{2}$ Figura here appears in the sense of argument, or charge. We may find figura used in a rhetorical sense, that of a 'forced figure', in adu. Val. 1.3: 'Sed naturae uenerandum nomen allegorica dispositio praetendens patrocinio coactae figurae sacrilegium obscurat...' Another doubtful case is found in scorp. 12.1. Referring to the privileged position of the apostles, Tertullian says: 'Cui potius figuram uocis suae declarasset, ...' What seems to be meant here is the technical expression for timbre, quality of voice used in speaking. ${ }^{3}$

In the de pudic. 14.4, Tertullian criticises the interpretation of certain texts of Paul. He urges, against the reading of Paul made by his adversaries, the whole tone of the first letter to the Corinthians: 'Animaduertamus autem totam epistolam primam, ut ita dixerim, non atramento, sed felle conscriptam, tumentem, indignantem, comminantem, inuidiosam et per singulas causas in quosdam quasi mancipes earum figuratam.'4

Moving away from this area, a second element in the figura complex in Tertullian attracts interest. We find figura reflected as translation of

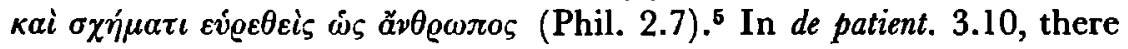
appears to be a reflection of Phil. 2.7, to some extent: '...qui in hominis figura proposuerat latere...' Again, allusive of Phil. 2.7 is the terminology

1 E. Aueraach, art. cit., p. 447-449.

2 Noted in ThLL VI. 1, 731. s Cr. Rhet. ad Her. 3. 15.25.

- Cf. ThLL VI. 1, 742 . B Cf. supra, ch. 1, p. 49 and notes. 
which Tertullian uses to describe the fact that the Marcionites also admit an Incarnation: '..et ipsi deum in figura et in reliquo ordine humanae condicionis deuersatum iam credidistis...' (adu. Marc. 2. 27.2). Closer to the text of Marcion-Paul is the comment of Tertullian on Phil. 2. 6-7: '....putant et hic Marcionitae suffragari sibi apostolum, quod phantasma carnis fuerit in Christo, cum dicit quod in effigie de $\mathrm{i}^{1}$ constitutus non rapinam existimauit pariari deo, sed exhausit semetipsum accepta effigie serui, non uerizate, et in similitudine hominis, non in homine, et figura inuentus homo, non substantia, id est non carne' (adu. Marc. 5. 20.3). Tertullian does not quote Phil. 2. 7 sufficiently to give a view of other renderings; he seems to prefer other formulas for the Incarnation.

Turning now to figurare $^{2}$ alone, in addition to the rhetorical meaning of this verb noted above, we see that the old sense of figurare, related to fingere, is still felt by Tertullian. ${ }^{3}$ A good translation of the term in English would be wrought; it is used of the work of creation. Thus, of the human nature of Christ, '..caro figuratus...' (apol. 21.14); '..deus noster, qui figurauit hominem...' (de coron. 5.1); ‘..qui eos de limo terrae...figurauerat...' (adu. Iud. 2.5)."

Thus far, we have seen some non-exegetical uses of figura and figurare, with some small attention to their previous history in Latin. For the other, related words, the case is different; they begin their history with Tertullian. Figuraliter, used once certainly (de test. an. 2.2), read by some editors in ad uxor. 1. 2.25, is read first in Tertullian, and then,frequently in ecclesiastical writers ${ }^{\mathbf{\theta}}$; figurate is much more frequent in Tertullian ${ }^{7}$, especially in the adu. Marcionem. That these two adverbs make their appearance for the first in Tertullian suggests linguistic innovation, naturally, and this is due to the shift of meaning in figura. ${ }^{8}$

Here, Tertullian is the first witness of a meaning in Latin, but he is

1 Cf. also de resurr. 6.4; adu. Prax. 7.8.

- Figurare, in all senses, occurs in Tertullian: ad nat. 1. 10.27; 2. 13.18; apol. 21.14; de praescr. 31.2 ; de orat. 4.1 ; de bapt. 4.1 ; adu. Marc. 1. 13.4; 2. 19.1 ; 2. 22.1 ; 2. 26.4; 3. 7.7 ; 3. 13.3 ; 3. 14.5 ; 3. 14.7 ; 3. 18.2 ; 3. 18.3 ; 3. 19.4 ; 4. 9.3;4.9.9; 4. 29.1; 4. 31.2 ; 4. 40.1; 4. 40.6; 5. 7.12; 5. 13.15; de cam. 43.10; de carn. 17.3 ; de resurr. 13.1 ; $19.2 ; 21.1 ; 26.1 ; 30.1 ; 31.1 ; 30.4 ; 31.8 ; 32.4 ; 33.8 ; 52.12 ;$ de castit. 6.1 ; de coron. 5.1 ; de idol. 24.4 ; de pudic. $9.13 ; 14.4$; adu. Iud. $9.13 ; 14.4$.

- See Rene Braun, Deus Christianorum, p. 402-403 on the development of figurare. - adu. Marc. 4. 29.1 is doubtless to be added to these texts, as Braun does, op. cit. note 2, p. 402.

Figuratio seems to occur only once in Tertullian: adu. Hermog. 33.2.

- See apparatus criticus ad loc, CC I, p. 374 (Kroymann), and note 4, p. 128, supra.

- ThLL VI. 1, 738.

7 Figurate in Tertullian : adu. Marc. 3. 5.3; 3. 13.9 (// adu. Iud. 9. 13); 3. 14.7; 4. 1.8; 4. 20.4; 4. 24.10; 4. 27.3; 5. 13.15; de resurr. 20.3; 42.15; de coron. 9.2; de idol. 5.4; adu. Iud. 9.6; 9.19 .

B Cf. E. Auerbach, art. cit., p. 450-454. 
unquestionably drawing on a tradition. If Tertullian reflected on the nature of prophetic utterance in the Old Testament, using aenigma, allegoria, figura, figurare, figurate, figuraliter, portendere, we not that aenigma, allegoria are localised to two tracts, for the most part. Figura and its related words are, on the other hand, distributed through the works of Tertullian (The decline in their use in the later works is doubtless due to the concerns of those works, and not alone to an increasing distrust of Scripture and the proofs drawn from it). And these words are used naturally, without reflection, often enough. Again, if Tertullian is innovating when he uses aenigma, allegoria, and parabola as a complex of terms to describe prophetic language, he is not original in his use of the idea behind figura. Two texts of Paul had shown the way to his pre-

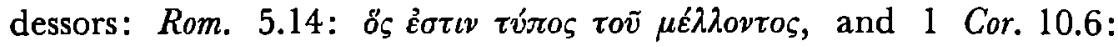
$\tau \alpha \bar{v} \tau \alpha \delta \dot{\varepsilon} \tau \dot{\varepsilon} \pi 0 \iota \dot{\eta} \mu \bar{\omega} \nu \dot{\varepsilon}^{\gamma} \gamma \varepsilon v \dot{\eta} \theta \eta \sigma \alpha \nu .{ }^{1}$ One can well begin, therefore, with an examination of these texts in Tertullian. ${ }^{2}$ The direct citations of these texts are not helpful. We do find 1 Cor. 10.6, from Marcion-Paul: 'Nam et reliquum exitum populi decursurus praemittit: haec autem exempla nobis sunt facta.' (adu. Marc. 5. 7.12). What we do find are echoes of these texts; prefacing the very frequent use of figura, etc. in the de bapt., we find: 'Angelum aquis interuenire si nouum uidetur, exemplum futuri praecucurrit...'; similarly, before the intensive use of figura in the adu. Marc., we find: Hanc prius dicimus figuram futuri fuisse.' (3. 16.4: cf. 5: 'Petra enim Christus - ideo is uir, qui in huius sacramenti imagines parabatur, etram nominis dominici inauguratus est figura, Iesus cognominatus........ Iesum autem ob nominis sui futuri sacramentum'). Reminiscent of Rom. 5.14 is the phrase is de resurr. 6.5: 'Ita limus ille iam tune imaginem induens Christi futuri in carne...'. Very unusual, in Tertullian, is the terminology used in de castit. 6.1 : '..si qui adhuc typi futuri alicuius sacramenti supersunt, quod nuptiae tuae figurent...' This seems to be an allusion to the significance of Abraham's children by Sara and Agar, interpreted by Paul in Gal. 4. 22-26.

We seem to see in these texts reflections of both Rom. 5.14, and 1 Cor. 10.6. Without entering in upon the extremely complicated history of sacramentum $^{4}$, the intimate connection of this word, reflecting the Pauline 1 Justin uses $\tau$ túzos in a clear allusion to Rom. 5. 14, in Dial. 114. 1; whence speaking of prophetic forms; in the nature of his argument with Trypho, he has to claim Old Testament texts as a basis.

2 As will appear, other Pauline texts are essential for Tertullian; the interest here, however, is on túros.

s Typus, a word found in Irenaeus latinus, also, seems to occur only here (de castit. 6.1), and twice in de idol. 24.4 (with which contrast terminology in de bapt. 8.4). Note also typicus in de patient. 6.1.

- On sactamentum, see Rene Braun, Deus Christianotum, p. 435-443. 
$\mu v \sigma \tau$ noto $^{1}$, with the entire complex of exegetical terms in Tertullian is to be underlined. In the texts cited above, we have already seen how sacramentum and figura occur together. One good illustration, among many, of the importance of sacramentum- $\mu v \sigma \tau$ ino complex is to be found in adu. Marc. 5. 6.1 ff.:

Hanc dicit sapientiam in occulto fuisse, quae fuerit in stultis et in pusillis et (in) inhonestis, quae latuerit etiam sub figuris, allegoriis et aenigmatibus, reuelanda postmodum in Christo.....

Nam ut absconderit aliquid is deus, qui nihil egit omnino, in quod aliquid abscondisse existimaretur, satis incredibile. Ipse si esset, latere non posset, nedum aliqua eius sacramenta. Creator autem tam ipse notus quam et sacramenta eius, palam scilicet decurrentia apud Israhel, sed de significantiis obumbrata...

This text departs from the Marcionite 1 Cor. 2.7. Eph. 5. 31-32 is also a central text, as we saw in adu. Marc. 3. 5.4, in Tertullian's theoretic defense of the deeper sense of Scripture, where '..pleraque figurate portenduntur per aenigmata et allegonas et parabolas, aliter intellegenda quam scripta sunt.' (3.5.3). Other striking texts where sacramentum and figura are closely associated: $a d u$. Marc. 3. 18.2; 5. 4.8; 5. 7.12; 5. 18.10. If Tertullian then, seizes on the word allegorica, allegorice, as used by MarcionPaul, that terminology is not so central in his entire exegesis. The terminology which revolves about figura is a far more important axis for his biblical interpretation. In this, he had several Christian predecessors; The Epistle of Barnabas, Justin, in his Dialogue with Trypho', Irenaeus, adu. haer. ${ }^{3}$, employ the language and the method which we call typology. ${ }^{4}$

It is impossible to trace figura, figurate, figurare, through the entire opus of Tertullian. Three remarks may be made, however. On figura: E. Auerbach has noted how Tertullian insists upon the historical existence of the figura as 'Realprophetie'. ${ }^{5}$ This is nowhere more evident than in the well-known commentary which Tertullian makes upon

1 We find only the plural, mysteria, in Tertullian: ad nat. 1.7 .13 (// apol. 7.6) 1. 7.25; apol. 6. 7; 29. 15; de praescr.40.2. Interesting is the single use of mystice, adu. Marc. 5.9.8. 2 Bamabas, ep. ch. 7. 1, 7. 10; 12. 5, etc.; Justin, Dial. 22. 3; 40. 1; 41. 1; 114. 1, etc. s Highly important in the adu. haer. Typus, as already noted, is the usual apparent translation in Irenaeus latinus.

- No effort has been made to define typology; Tertullian uses figura terminology with far less reflection than the other words of his exegesis. For a modern, Catholic view see P. Grelot, L'interpretation Catholique des livres saints in: Introduction à la Bible, (ed. par A. Robert et A. Feuillet), Tournai, 1959, esp. 203-210. See also the working definition offered by R. P. C. Hanson, Allegory and Event, p. 7. See also G. ZmmmermanN, op. cit., p. 9-10. In Tertullian, both figura and allegoria/aenigma, etc. have primary bearing on the relation of the testaments. But this is not exclusively the case.

E. Auerbach, art. cil., p. 150; and 150-154. 
Ezechiel 37. 1-14 (de resurr. $29.2 \mathrm{ff}$. quotes the text; $30.1 \mathrm{ff}$. comments). ${ }^{1}$ Tertullian's argument, which sounds strange to us, is: unless the bones in the valley were really re-united, and unless they really rose again, the vision of Ezechiel could not itself be revelatory of the resurrection, or of the restoration of Israel. The theme, that the figurae have their own consistency, and are rooted in history, if they are to have the force of revelation runs through Tertullian. A good text is found, for example, in adu. Hermog. 34.3: 'Quae omnia et si aliter putauerit (spiritaliter) interpretanda, non tamen poterit auferre ueritatem ita futurorum, quomodo scripta sunt. Si quae enim figurae sunt, ex rebus consistentibus fiant necesse est, non ex uacantibus, quia nihil potest ad similitudinem de suo praestare, nisi sit ipsum, quod tali similitudini praestet.' The same basic reasoning is found in adu. Marc. 4.40.3 ff., etc. ${ }^{2}$ This concern of Tertullian, to found the figura in the history of salvation is, perhaps, related to his appreciation of the rhetorical sense of figura, and its fictitious connotation.

On figurare: Tertullian is original in the meaning in which he uses this word in Latin. ${ }^{3}$ We have already seen how he uses the word in the sense of create, and how he is conscious of the original meaning of the Latin word. In an interesting text ${ }^{4}$, we see the two meanings come together: figurare, to shape-create, figurare, to figure forth: 'Si enim Adam de Christo figuram dabat, somnus Adae erat Christi dormituri in mortem, ut de iniuria perinde lateris eius uera mater uiuentium figuraretur ecclesia.' (de anim. 43.10). It is Christ who figures forth in the Old Testament (adu. Marc. 4. 40.6; cf. 3. 19.4. Finally, we find praefigurare once, in de praescr. 26.3, interpreting a New Testament parable.

Lastly, while figura and its related words occur throughout most of Tertullian's works, there are two works in which it is found very frequently: the de bapt., and the adu. Marc. The latter, following Justin and Irenaeus, and then appealing to this terminology in the fourth and fifth books, establishes the continuity between the Christ of MarcionLuke, Marcion-Paul, and the Old Testament. The de bapt. is not concerned with this, typically anti-Jewish, argument, but is concerned to show how Baptism was prefigured, not only in the Old Testament (4.1; cf. 8.3; 8.4; $9.1 \mathrm{ff} . ; 20.4)$, but also in the New Testament (5.5; 6.1; $12.7 ; 19.1)$.

Tertullian, then, following in the tradition of his Christian predecessors, and inspired by the example of Pauline terms, interprets both

1 Cf. Jerome, in Hezech. 11. 37.1/14 (CC LXXV (F. Glorie), p. 512-516).

See E. Auzrbach, art. cit., p. 150-154 for other examples.

- ThLL VI. 1, $743 \mathrm{ff}$.

- Noted by E. Auerbach, art. cit., note 20, p. 451. 
Old and New Testament through figures. Here, the great axis is the relation of the two testaments; but it is accompanied also by a line which interprets Old and New Testament for Christian life. In so doing, he appears as witness of linguistic innovation: for the very words, figurate, figuraliter; and for the new meaning which figura and figurare take on. Here again, he is doubtless in a tradition of Latin-speaking Christians. The older meanings of these words are occasionally visible. But they are used almost always for the interpretation of the Bible.

\section{Portendere}

Tertullian, it will be remembered, glossed allegorica with '...id est aliud portendentia...' (adu. Marc. 5. 4.8). ${ }^{1}$ In that dense text of adu. Marc. 3. 5.3, we find: '. .pleraque figurate portenduntur per aenigmata et allegorias et parabolas...' Again, we find the word in a context with figurate: '.. figurate scorpios et colubros portendi spiritalia malitiae..(scl. scimus)' (adu. Marc. 4. 24.10). A brief glance at this word is in order. The verb portendere is read from Ennius on, and is usually employed in the meaning: a sign which indicates a future evil. ${ }^{2}$ It also indicated future good, occasionally. Tertullian uses the word with fair frequency, to indicate the future meaning of the Scriptures. ${ }^{3}$

If we find the substantive, portentum in its normal, classical meaning (apol. 20.3, though associated with Scripture; de spect. 9.3), the verb is almost always used in the context of the interpretation of Scripture. It can have the simple signification, to mean (thus, of Hermogenes' interpretation of Gen. 1.2, adu. Hermog. 30.1; 37.3; adu. Marc. 4. 8.10; 4. 24.8; adu. Marc. 4. 26.10;4 . 29.8; 4. 30.3; de resurr. 39.7; 48.11; de fug. 4.1; adu. Prax. 28.9; de uirg. uel. 7.3; de monog. 8.3; de pudic. 7.13). Other texts, however, are more interesting.

In the de bapt. 8.2, Tertullian cites the crossed hands of Jacob, blessing the sons of Joseph (Gen. 48. 13-14), and sees a deeper meaning there, aimed at the future: '..de ueteri sacramento....et intermutatis manibus benedixit et quidem ita transuersim obliquatis in se ut Christum deformantes iam tunc portenderent benedictionem in Christo futuram.' (de bapt. 8.2). In the adu. Marc., Tertullian disputes the literalist interpretation which Marcion

I See R. P. C. HANson, art. cit., JTS n.s. 12 (1961), p. 273, who sees in the gloss, '..id est aliud portendentia..' a reminiscence of Heraclitus, quaest. Hom. 22.

2 Livy uses portendere very frequently, usually of omens of future outcomes; Seneca, nat. quaest., 2. 32.1: '..quod futura portendunt..' Pliny, ep. 1.18.2, for the sense of a favorable promise of the future.

a Portendere would seem to correspond to the Greek regaroגoyeiv, 'to tell of marvels, of strange phenomena.' But in Tertullian, portendere is very nearly always associated with the meaning of the Scripture, and generally, towards its future fulfillment. 
made of Is. 8.4: 'Aeque sono nominum duceris, ....quasi bellatorem portendant Christum creatoris...' (adu. Marc. 3. 13.1). So of the mysterious Tau in Ezech. 9.4: '..Tau,...species crucis, quam portendebat futuram in frontibus nostris...' (ibid. 3. 22.6), of twelve in the Old Testament, signs by which '..totidem enim apostoli portendebantur...' (adu. Marc. 4. 13.4). A New Testament locus has a possible future interpretation: '..et sublectionem loco eorum...de futuro portendit. (ibid. 4. 31.8). Portendere is used to indicate the familiar image of the stone, significant of Christ: 'Vanum enim, si credimus deum de contumelia aut gloria silicis alicuius praedicasse, ut non eum portenderet et in lapidibus, quem et in petrae et in montis figura portenderat.' (ibid. 4. 35.15). Saul against David is a portent of Saul (later Paul) against Jesus; and Tertullian follows this use of portendere with familiar terms: 'Haec figurarum sacramenta...' (ibid. 5. 1.6).

Scripture, says Tertullian, is prophetic in its events, as well as in its words; and when Moses thrust his hand into his bosom, and brought it out whole, 'nonne hoc de toto homine portendit?' (de resurr. 28.1).

We find the word again associated with figura in de coron. 9.2. Tertullian has just cited the examples of Old Testament men and institutions, all without crowns. Alluding to the text 1 Cor. 10.6, important for the figura idea, he proceeds: 'Atquin si figurae nostrae fuerunt - nos enim sumus et templa dei...... -, hoc quoque figurate portendebant, homines dei coronari non oportere. Imagini ueritas respondere debebit.'

Since this overview of portendere began with the gloss which Tertullian made, in he fifth book Against Marcion, on allegorica, where the text Gal. 4. 24 was being commented on, it is convenient to conclude with a text from de monog. 6.3, where this same text is reflected, in the same terminology with which Tertullian had made his earlier gloss. His adversaries urged the polygamy of the patriarchs against Tertullian, and he answers, appealing to Paul's interpretation of the children of Abraham's wives: 'Aliud sunt figurae, aliud formae. Aliud imagines, aliud definitiones. Imagines transeunt adimpletae, definitiones permanent adimplendae. Imagines prophetant, definitiones gubernant. Quid digamia illa Abrahae portendat idem apostolus docet interpretator utriusque testamenti...'

Portendere $^{1}$ is a familiar term for Tertullian. He uses it often in contexts with the other exegetical words which we have seen, and as a gloss for allegorica. The word is almost always used in Tertullian of the interpretation of Scripture; sometimes with the simple idea of the meaning, more often with the idea of the signification, the promise of the Old Testament for the future.

:To the citations noted in the text, supra, need only be added the following other occurrences of portendere: adu. Marc. 5 . 10.4; de anim. 18.3; 46.5; adu. Iud., 9.4. 
As seen in the first chapter, ${ }^{1}$ Augustine mentions that the translations which he knows render Gal. 4.24 by a circumlocution, 'quae sunt aliud ex alio significantia.' Now, we find significare ${ }^{2}$ very frequently in Tertullian, often enough in exegetical contexts. While some of these texts have to do with the deeper meaning of the scriptures (adu. Marc. 2. 19.1; 5. 6.2; de resurr. 21.1 ; scorp. 11.7), significare does not have the close association with figura, sacramentum, etc., which portendere does have.

\section{Simplicitas}

Dom P. Antin ${ }^{3}$ has dedicated a notice to the ideas of simple, simplicity in St. Jerome, used in his approach to the Bible, in his moral theology, and in polemic. Simplicitas, simpliciter, etc. form, in Tertullian also, an interesting complex. In studying these words in Tertullian, with the main attention to their use in exegetical connections, we will have occasion to return to almost all the words of Tertullian's exegetical vocabulary which we have already seen. If figura was one central axis of Tertullian's exegesis, simplicitas, simpliciter, etc. form another, which is also interesting, if less important.

Simplicitas is found for the first time in Latin in Lucretius. ${ }^{4}$ While Livy uses the word in describing style, ${ }^{5}$ in the sense of simple, unadorned, unsophisticated, simplicitas is not frequently found until Silver Age Latin and later. Simplex is found in the meanings of unmixed, as Cicero uses it, speaking of the life principle $;^{6}$ describing an unsophisticated person, we find the comparative in Horace. ${ }^{7}$ The adverb simpliciter is found often in rhetorical contexts, of unadorned composition. ${ }^{8}$

This complex of words forms an interesting theme in Tertullian which is larger than immediately exegetical connections. For Tertullian, the truth is simple: 'Quid isto opere manifestius?...Simplicitas ueritatis in medio est,.... 8. Quid..inici potest aduersus id, quod ostenditur nuda sinceritate?' (apol. 23. 7-8). Similar to this is the idea that philosophers, although they drew on the scriptures, alloyed the truth of them with other opinions: 'Nam et si qua simplicitas erat ueritatis eo magis scrupulositas humana fidem aspernata nutabat, per quod in incertum miscuerunt etiam quod inuenerant certum.' (apol. 47.4 ; cf. // ad nat. 2. 2.5). These texts are interesting 1 supra, p. 55.

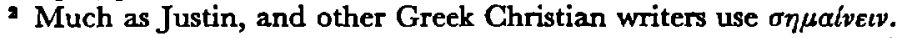

'P. Antris, 'Simple' et 'Simplicité' chez saint Jłrôme, Revue Bénédictine 71 (1961), p. $371-381$.

'de rer. nat. 1. 548: 'Sunt igitur solida primordia simplicitate..' It is used in Lucretius about four times.

- Livy, 40.47.3: '..quonum sermo antiquae simplicitatis fuit..'

- de nat. deor. 3. 14.34. ${ }^{7}$ serm. 1. 3.63.

B Cf. Rhet. ad Her. 3. 4.8; 4. 32.43; 4. 43.56. 
because of the association of simplicity with the scriptures; an idea which returns in Tertullian. Rather than explain by an appeal to figures, Tertullian would solve the problem of the violation of the Sabbath in the Old Testament simply, '..simplicitate ueritatis...' (adu. Marc. 2. 21.2).

The simplicity of the truth is urged against the philosophers; we find an opposition between pagan literature, and Christian truth; 'Hac simplicitate ueritatis contraria subtililoquentiae et philosophiae, nihil peruersi possumus sapere.' (adu. Marc. 5. 19.8; cf. 7. 20.5). The simplicity of the truth, over against the subtlety and complicated arguments of philosophers is an important element in the anti-philosophical polemic of Tertullian (cf. de anim. 2.5; 18.7: 'Unde ista tormenta cruciandae simplicitatis et suspendendae ueritatis?').

God is to be sought in simplicitate cordis (de praescr. 7. 10, reflecting Wisd. 1.1 ; cf. the same expression, used of the sacrifice of Abel, adu. Iud. 2.12) ${ }^{1} \mathrm{He}$ appeared to Elias, in the last of the signs, apertus et simplex (de patient. 15.6) being simple, he would not have deceived men in a merely docetist Incarnation (de carn. 5. 10). The simplicity of his sacraments, and the splendor of their effects is a puzzle to men (de bapt. 2. 1-2).

The whole range of meanings of the complex, simplicitas, is found in Tertullian. Before coming to the exegetical uses of these words, some others may be noted. Tertullian describes the soul as simple (de anim. $10.1 ; 11.1 ; 11.6 ; 12.2 ; 21.3 ; 22.2$, etc.); the words simplicitas is used often in the de cult. fem., naturally $(1.2 .4 ; 2.7 .1 ; 2.9 .1 ; 2.13 .7)$, as is simplex (2. 4.2; note 2. 5.1: '...simplices et sufficientes munditiae....') ${ }^{2}$.

Tertullian deals with simplicity in persons, and in literary texts. Between the two, there is a tension. The admonition of the gospel (Matth. 10.16), '..estote...simplices ut columbae..' (de bapt. 8.4) is interpreted, following upon the figura of the dove, as a moral state of innocence. The dove is later appealed to as an argument for monogamy (de monog. 8.7), and the text is alluded to in adu. Marc. 3. 24.11. If simplicity is a virtue (de paenit. 1.4), it is not always so.

The intellectual quality which is suggested by simplicitas, simplex, is not highly regarded by Tertullian. He mentions the puzzlement of those whose fides is simplicior, when they find no clear scriptural authority for the avoidance of the games (de spect. 3.1).$^{3} \mathrm{~A}$ growing awareness, and a certain contempt is visible in Tertullian, with regard to the

1 Cf. adu. Marc. 2. 22.3; adu. Val. 2.2.

2 Cf. Horace, carm. 1. 5.5: '...simplex munditiis..',

3 Cf. also adu. Iud. 9.8; de cult. fem. 1. 2.2. 
intellectually unsophisticated. In the de praescr., he disagrees with the heretical idea of simplicity, which does away with all disciplina (41.3), and this affected simplicity is found again in adu. Val. 1.4: '...fatua simplicitate suam caedem dispergunt.'. The opening chapters of the adu. Val. mark the beginning of an attitude which we find in the later Tertullian: a certain contempt for the unsubtle many. He is first of all irritated that the orthodox are regarded by the Gnostics as simplices (2.1), and Tertullian defends the proper idea of simplicity, quoting Matth. 10.16. As we have seen, he sees the serpent so completely as symbol of evil, that he virtually disavows the first member of the gospel logion, 'Estote prudentes ut serpentes...., although this is also due to his eagerness to defend the evangelical, intellectual idea of simplicity (2. 1-4). The dove, then, is the sign of that simplicity which the Christians claim; 'Et tamen simplices nos omnia scimus.' (3.5; see 3. 1-5). Later, however, and usually in anti-Gnostic works, we see that certain disdain of Tertullian for the simplices and the rudes.

In the de resurr., Tertullian explains that the aim of his tract is not merely to refute heretical ideas on the resurrection, but also to confirm the faith of his less astute fellow believers: '..nam et multi rudes et plerique sua fide dubii et simplices plures, quos instrui dirigi muniri oportebit...' (de resurr. 2.11). For them, Tertullian must play the rhetor, as he must play the philosopher against the heretics $(5.1)$; for, '..et rudes quique..de communibus adhuc sensibus sapiunt et dubii et simplices per eosdem sensus denuo inquietantur...' (ibid.). He is quick to correct the assumption of somewhat naive believer, that the body also will appear at judgment, else how would the soul be capable of suffering (..Simplicior..fautor sententiae nostrae..' 17.1).

In the scotp. the same note is found. The Gnostics know that many of the orthodox are uncertain in their attitude towards martyrdom: 'Nam quod sciant multos simplices ac rudes tum infirmos....' (scorp. 1.5). The simple do not know how to answer to objections, and think it stupidity to die for God, who saved them: '...nesciunt simplices animae, quid quomodo scriptum sit, ubi et quando et coram quibus confitendum, nisi quod nec simplicitas ista, sed uanitas, immo dementia pro deo mori, ut qui me saluum faciat.' (ibid. 1.7).

Defending his doctrine on the Trinity, Tertullian says that the heretical seeds have been sown, while many were sleeping '...in simplicitate doctrinae...' (adu. Prax. 1.6), and Tertullian's attitude is plain, when he says: 'Simplices enim quique, ne dixerim imprudentes et idiotae, quae maior semper credentium pars est...expauescunt ad oikonomiam.' (ibid. 3.1).

This growing attitude of Tertullian, especially in his later works, 
stands in contrast to his use of simplicitas, etc., when interpreting biblical texts. Tertullian had appealed to the witness of the soul, precisely as a non-literary argument; '..te simplicem et rudem et impolitam et idioticam compello...' (de test. an. 1.6), and its evidence is simple, therefore divine (ibid. 5.1). When appealing to, or interpreting Scripture, Tertullian uses the simplicitas group in several ways. Against those who would see too much in a text, as some did in the case of Hermas, Tertullian comments that there is no deeper meaning there; it is simpliciter there, for the purposes of narration (de orat. 16.2); he is careful not to draw too much from a text (de orat. 25.5), and he explains the significance of some scriptural statements: 'Non utique sic intelligendum est sed simpliciter dictum more communi...' (de bapt. 11.2). Marcion draws too much from the '...simplici capitulo dominicae pronuntiationis..' of the good and bad tree and their fruits (adu. Marc. 1. 2.1). He also prefers the simpler explanation at times ( $a d u$. Marc. 5. 9.10; 5. 11.11, after a first, elaborate reading of a difficult text, Tertullian says: 'Simpliciori responsu prae manu erit...; de carn. 18.1 : Nunc et simplicius respondeamus...'; etc.). The preference for the simpler reading is seen also in de orat. 4. 1-2. Tertullian first suggests the interpretation: 'Ex interpretatione enim figurata carnis et spiritus nos sumus caelum et terra. 2. Quamquam et si simpliciter intellegendum est, idem tamen est sensus petitionis, ut in nobis fat uoluntas Dei in terris,...'. Similarly, Tertullian knows of the figure of synagogue/Church, but has a simpler interpretation prepared for the polygamy of the patriarchs: '..ut tamen simpliciter interpretemur, necessarium fuit instituere quae postea aut amputari mererentur.' (ad uxor. 1. 2.2). Instead of an appeal to the figurae of the Old Testament, which he knows that Marcion will reject, Tertullian turns to the simplicity of truth, and the rabbinical answer to the problem of the Sabbath (adu. Marc. 2. 21.2); the pronouncements of the Spirit in prophecy must be consistent with the simplicity of clear utterances (de carn. 23.6); simple pronouncements of Scripture, being more obvious than allegory, parables, must either be accepted, or simply rejected (adu. Prax. 13.4).

Tertullian has to prove against Marcion, on the other hand, that Scripture has a deeper meaning. The question of God, in the garden, is not to be read '...simplici modo...', but as a question (adu. Marc. 2. 25.2); the fact that the first apostles were called from the fishing boat must have a deeper significance, and is not to be read simply (ibid. 4. 9.1); similarly of the number twelve, for which Tertullian can find an earlier promise in the Old Testament: 'Quid tale de numeri defensione competit Christo Marcionis? Non potest simpliciter factum ab illo quid uideri, quod potest uideri non simpliciter factum a meo.' (ibid. 4. 13.5). But this 
concern to find the deeper meaning has its prudent moments: 'Et utique scimus - salua simplicitate scripturae, nam nec et ipsae bestiae nocere poterunt, ubi fides fuerit - figurate scorpios et colubros portendi spiritalia malitiae...' (adu. Marc. 4. 24.10). Even in the midst of his search for the deeper significance, Tertullian is nonetheless careful to preserve the directness, the simplicity of the Scripture. If he sometimes disagrees with an interpretation as being not subtle enough to do justice to the scriptural text (ad uxor. 2. 2.2; adu. Prax. 5.3, of the current translation of foh. 1.1; de monog. 11.11), Tertullian often insists on the clarity and simplicity of the scriptures, and criticizes the intricate arguments of heretics in the face of scriptural clarity. On the interpretation of the opening lines of Genesis, which Hermogenes and others made, Tertullian says: 'Itaque occasiones sibi sumpsit quorundam uerborum, ut haereticis fere mos est simplicia quaeque torquere.' (adu. Hermog. 19.1). Again, of their reading of erat, indicating the prior existence of matter, Tertullian observes: 'Haec sunt argutiae et subtilitates haereticorum, simplicitatem communium uerborum torquentes in quaestionem.' (ibid. 27.2). If Marcion read the Old Testament too simply and literally, in order to show a radical discontinuity between Old and New Testaments, Tertullian often criticises his overly subtle interpretation of the New: '..semper haeretici aut nudas et simplices uoces coniecturis quo uolut rapiunt aut rursus condicionales et rationales simplicitatis condicione dissoluunt, ut hoc in loco.' (adu. Marc. 4. 19.6) : '... quae ratio tortuositatis istius, cum simpliciter pronuntiare potuisset...' (ibid. 4. 43.7).

Tertullian's view that the meaning of the scriptures is clear appears more frequently in works like the de carne, and de resurrectione. 'In Christo uero inuenimus animam et carnem simplicibus et nudis uocabulis editas....' (de carn. 13.4); the simplicity of Scripture is asserted, in a passage which shows how Tertullian labors to preserve both the historical consistency of prophecy, and its realization, and yet the deeper meaning in both; the passage is worth quoting more fully:

Quae et si spiritaliter quoque interpretari solemus secundum conparationem animalium uitiorum a domino remediatorum, cum tamen et carnaliter adimpleta sunt, ostendunt prophetas in utramque speciem praedicasse, saluo eo, quod plures uoces eorum nudae et simplices et ab omni allegoriae nubilo purae defendi possunt... (de resurr. 20.7)

In another passage which we have already seen, simplices has very nearly the meaning of 'literal', as elsewhere, also: 'Igitur si et allegoricae scripturae et argumenta rerum et simplices uoces resurrectionem carnis..obradiant..' (de resurr. 29.1), but Tertullian had noted of those simplices uoces another element: 'Sunt et quaedam ita pronuntiata, ut allegorae quidem nubilo 
careant, nihilominus....simplicitatis... sitiant interpretationem.' (de resurr. 28.5).

As appears from the last passages quoted, Tertullian has to admit a certain obscurity in Scripture. But simplex, simplicitas more often assert the clarity of Scripture. From claiming clarity, it is but a step to the limiting of the meaning of parables which we find in the de pudic., and where many of the exegetical rules of Tertullian are formulated. 'Huiusmodi enim curiositates et suspecta faciunt quaedam et coactarum expositionum subtilitate plerumque deducunt a ueritate. Sunt autem, quae et simpliciter posita sunt ad struendam et disponendam...parabolam...' (de pudic. 9.3): this against the readings of the Lucan parables of mercy (Luc. 15. 4-11), with which Tertullian must disagree, if he is to hold his present position. For his limiting interpretation of Luc. $15.11 \mathrm{ff}$., he attempts to appeal to an explanation based on a view of the purpose of Christ's activity: 'Quod si nec in Iudaeum integre filii imago concurrit, ad propositum Domini simpliciter gubernabitur.' (ibid. 9.12).

One last text may be cited. Tertullian suggests where the Christians ought to find their entertainment: 'Si scaenicae doctrinae delectant, satis nobis litterarum est, satis uersuum est, satis sententiarum, satis etiam canticorum, satis uocum, nec fabulae, sed ueritates, nec strophae, sed simplicitates.' (de spect. 29.4). There is a suggestion here of the stylistic simplicity of the Bible, in contrast with pagan literature.

There are many elements in the complex, simplicitas. Singling out rhetorical, moral, and intellectual aspects, the following comments can be made. Tertullian has made of simplicitas a word of praise, when he uses it to describe the scriptures. Even before him, simplicitas was by no means always a reproach; but Tertullian is far from the feeling of later times that the Scripture was simple, in the sense that its style was rude. In his praise, however, and in his claim that the scriptures are simple, direct, clear, there is visible a felt need on his part. It is natural that he tends to limit the portée of Scripture. And, in the effort to limit Scripture, he is even more subtle than the adversaries whom he criticised.

Simplicitas, simplex cause Tertullian difficulties, because he does not seem to distinguish a moral simplicity, and an intellectual one; the one a virtue, the other a defect. He clings to the word, especially in the $a d u$. Val.; Tertullian is piqued at being called simple by the heterodox, yet the biblical simplicity is enjoined on the Christian. There is then a visible movement in Tertullian towards a growing disdain for the intellectually unsophisticated.

Applied to the Bible, simplicitas, simplex, simpliciter are almost always said in praise. The Scripture is direct, open, limpid. There is only a 
suggestion that this simplicitas has something of the disapproving critic, when, in the de spect. 29.4, Tertullian contrasts the Bible with the stories and plays of the pagans. As was seen in the first chapter, Tertullian can even assert that the Scripture speaks 'elegantly'. Aware of the obscurity in biblical language, he glosses the occasional word which might be unclear. But his use of simplicitas is a wish, rather than an observation. The closing lines of the de resurrectione show what Tertullian sought in the simplicity of the Scripture, and which he was compelled to find outside Scripture.

This brings us to the end of a brief view of the five words, and groups of words, about which Tertullian's exegesis revolves. Of the five, aenig$m a$, clearly, is the least important, figura the most central. It is interesting to note that aenigma, allegoria, figura, and simplicitas, all have relations with the language of rhetoric. But the origin of the terms is not to be sought there. This is most evident for figura, which, following his predecessors, Tertullian roots in Paul. It may be that he insists so much upon the historical reality and consistency of figurae, not only against Gnosticising tendencies, which would make of them myths, but also to distinguish them from the figurae of the rhetoricians.

Tertullian is able to find the word, allegorica, in the text of his adversary, and thus to justify his use of the method in showing the relation of the two testaments. How occasional this was, however, appears from the limited use which he makes of allegory terminology. Figura, figurate, are far nore central. And, in the two works where he does employ allegory, Tertullian's attitude is nuanced according to the arguments of his adversaries.

Portendere is interesting in that a considerable change has been wrought in the word, when Tertullian uses it in his biblical exegesis. With a certain history of religious use, Tertullian nonetheless seizes on it, and uses it to bring out what significare did not do so well: the bent of the Scripture towards the future. The simplicitas complex, finally, is far less technical than allegoria and figura. The complex has values so in tension with one another that the meaning of the words is elusive in Tertullian. He notes the simplicitas of the Scripture with approval; we are not yet into Jerome's problematic. But this simplicitas, which Tertullian would see in the Bible, in not a stylistic quality, but one of evidence. 


\section{CONCLUSION}

The ambitions implicit in the title of this study are at once tempered by the subtitle, and its three clarifying words, which also indicate the subjects of the three chapters: language, imagery, exegesis. To speak of Tertullian and the Bible, without limiting modifiers, would take many more volumes.

It will be apparent by now that a synthetic, unifying view of Tertullian is difficult; he is very largely determined by the subject matter, and the adversary of the moment. What is true of one work is not always true of another. Therefore, many of the observations made in the preceding remain discrete fragments. But some attempt should be made to bring some unity to this assemblage of facts, texts, and remarks.

A first tour d'horizon is possible for all three chapters, following the idea of otherness. Tertullian is conscious of the otherness of biblical language, imagery, and of the nature of the biblical message, and the manner of its expression. Of biblical language: Tertullian, alive to language, accomodates his style and his vocabulary to the readers of his various tracts. There is an evident development in his own mentality, and in his style; but there is also this attention to his public, and to the language which would be suitable to them. The apologeticum, the Greek edition of the de spectaculis, the de pallio, and that remarkable adaptation of language in the de pudicitia, where, abandoning his ordinary terminology of adulterium and stuprum, he takes over what seems to have been the vocabulary of the edictum, moechia and formicatio: all these adaptations testify to Tertullian's awareness of language.

In the light of this sensitivity, his glosses on biblical and Christian words are readily understood. He is quite aware of the otherness of biblical words: of sophia, sermo, moechia, fornicatio, caro et sanguis, cor, adpretiatus, problemata, and so many others. He explains these words with glosses, giving their meaning with other, more ordinary Latin words. So, too, of Christian words; paenitentia is different, because it 
has a new and deeper meaning, and this must be explained; exomologesis is really a Greek word, but is currently used by the Christians.

Now, this otherness is not simply limited to biblical language in contrast with good classical Latin. Tertullian indicates that certain words have a special resonance for groups within the Christians: ecstasis is the best example, and effundere may also be mentioned. These words have special associations for Montanists, and Tertullian glosses ecstasis (with amentia and other expressions) more frequently than any other word; and we may suppose that moechia/fornicatio, contrasted with adulterium/ stuprum, also represent differences in Christian usage. Tertullian then, is aware of the otherness of biblical, and Christian, language, and this leads him to glosses; always with an eye towards clarity, always with an eye to his varying classes of readers.

This sense of otherness is also found in the chapter on imagery. Tertullian often reflects on the special meaning of biblical imagery, and the deeper meaning which it has; where he glossed language, he explains the imagery of the Bible, notably in the case of water, of clothing, of arms, and athletics. Sensitive to language, the imaginative Tertullian is also sensitive to imagery; he explains it, and draws attention to its otherness.

Finally, in exegesis: as Tertullian begins his great commentary on Marcion-Luke, Marcion-Paul, he calls attention (as Justin had done before him) to the special nature of prophetic utterance, and how it announces the future as if present, and speaks in terms which are be understood in a deeper sense than the apparent, literal (but impossible) one.

Secondly: we may also unify the three chapters along the opposite line: that of continuity between the biblical and the classical, circumambient world. There are only a few indications of this in the case of language. He mentions that the pagan world, also, uses mulier as an expression for 'wife'; and he decides that this is due to the remote influence of Scripture.

For imagery, the continuity is much more evident. Tertullian uses imagery which, as we have seen, always has a certain root in the classical world and literature. All of the great axes of his imagery are used in the classical Latin manner; but, imperceptibly, they are quickened and transformed by the biblical associations which they have. An interesting illustration of this may be pointed out in the de coron. 8. 2-5. In this passage, Tertullian seems to be citing the argument of his fellow Christians that all things are good, for they all have their justification in the Bible. But the striking thing in the text is the presentation of 
'progress', from the invention of language and song, of medicine, of sea-faring of clothing; just as Lucretius and Vergil had traced them. And for every classical, symbolic presentation, Mercury, Asclepius, Minerva, there is a biblical parallel. This text can be used as illustrative of the continuity between the classical and biblical sources of his imagery.

And so it is, too, with exegesis. Tertullian comes to his task of exegete with his considerable powers as literary analyst, and with his training as rhetor. Where Old Testament problems might be solved with rabbinical solutions, New Testament difficulties require other solutions; and Tertullian sometimes finds these in the literary analysis which he had learned in those pagan studies, whose necessity for scriptural studies he defends.

With these two threads, then, it is possible to unify the material of the three chapters. But, just as each work of Tertullian must be treated apart, so it is with each of these chapters.

In handling the problem of biblical language, the express intent was to make the base of the study broader than a simple re-examination of the classic texts; those texts which have been cited so often to prove, or to disprove that Tertullian knew translation(s) of the scriptures into Latin. These texts were examined also from another point of view: Tertullian is aware, not only of the impreciseness of the versions of some biblical texts current at his time, but he is also aware of the otherness of biblical language, and expressions. And this glossing technique of Tertullian provides us with a new perspective on the so often quoted classical texts. Of the many comments made in chapter one, four striking things seem to emerge.

Tertullian is already occupied with remarks on the impreciseness, or strangeness of biblical language, in much the same way that Augustine and Jerome later will be. As they cite varying translations current at their time, Tertullian, too, comments on sermo, dormierit, spiritus, parabola, data, uictoria/contentio, and others. This is the purpose of the citations made from Jerome, Augustine, and others; to show how they are following in a tradition which is as old as Tertullian.

The special problematic of the aduersus Marcionem was approached from the viewpoint of Tertullian's glossing technique. In this optic, we seem to see Tertullian in the presence of two terminologies. The one is orthodox, highly biblical in tone, in need of explanation. Many of these texts resemble testimonia; proof texts from the Old Testament which indicate that the full meaning of the Old Testament is to be found in Christ, and in the New Testament. The many glosses of the 
terminology of these texts shows that Tertullian, feeling their strangeness, attempts to bring them closer to ordinary language. And so he comments on portare, parabola, problemata, adpretiati, fliis hominum, ascendit in sublimitatem, data, etc.

But there is also another movement, which seems to attempt to explain Marcionite terminology to the orthodox. The Marcionite term antithesis is explained; perhaps uictoria, and not the more usual contentio, was the Marcionite reading of 1 Cor. 15. 45.

Although there remains a great element of uncertainty, the striking numer of glosses in the aduersus Marcionem, when seen in the light of this technique elsewhere in Tertullian, seems to indicate that he is balancing between two terminologies, and attempts to harmonise the one with the other for the purpose of his argument, the unity of the two testaments.

In the de pudicitia we see Tertullian suddenly conforming to terminology which is at once that of scriptural versions, and that of moral theology. It is not (as the usual translation would have it) that Tertullian sophistically equates moechia and fornicatio, and solves the moral problem with an appeal to the ipsissima uerba of Scripture. Rather, he uses these words in place of his own, constant terminology elsewhere (adulterium and stuprum), and, at the same time, he makes a distinction between the two sins, as his adversaries did. Left to his own, Montanist inclinations, such distinctions appeared unnecessary; but the good polemicist meets his adversary on the adversary's own ground, and he treats them separately; first, moechia, then fornicatio. Tertullian suddenly comes into contact with structured, heavily scriptural vocabulary, which was in usu. Before the de pudicitia, there is hardly a trace of this terminology; this raises questions, one may observe, about the identity of the 'Pontifex maximus.... episcopus episcoporum....' (de pudic. 1.6).

Finally: a correlation of similitudo with Luke is noted. When similitudo is used in the sense of 'New Testament parable', in every case but one, the word refers to a Lucan parable. This correlation extends beyond the adu. Marc.; and seen also in the light of that special profile which Luke seems to present in Tertullian, where Lucan stories are introduced with ille, etc., suggests that Luke already has its own, structured, characteristic language.

Moving on to chapter two, we note that Tertullian uses about eight prominent axes of imagery. All of these themes are rooted in the classical Latin tradition, and also in the Bible. We move imperceptibly from the one to the other, and it is always the biblical which dominates.In his use of imagery, Tertullian is logical, consistent, controlled. If his 
articulation of some images seems overfull to us, it rarely lapse, into mixed figures. In the mixture of biblical and classical in some figures, Tertullian is seen as an important link in the development of a literary tradition; in different ways, this is true of medicine and bestiary themes in particular. Tertullian is capable of seeing the image value of words which we should expect to be clichés; throughout his works, he appeals to images in a consistent way. This is notably true of clothing, and of water imagery, which always serve given functions in his treatises. Finally, a linguistic note on his imagery: certain words are wholly, or almost so, associated with given biblical texts. Typical examples are found in effundere, potare, rigare, inundare, in water imagery; in induere, superinduere, superindumentum, in clothing imagery.

In the third chapter, the centrality of figura and its related words stands out. Tertullian is the first witness in Latin to figurate, figuraliter; he is also the first to witness to the important change of meaning which has occurred in figura itself. Here we may suppose that he is not completely original; that in his church, and in his time, figura was already an ordinary word. While he comments on many other words, figura is used without self-consciousness; it is not glossed as such. The crossing of figura with the rhetorical term is accidental; as a term of exegesis, figura is wholly rooted in Paul, and is used to express the relation of the Old to the New Testament, and of the Bible to Christian life.

Tertullian's originality in the use of allegoria is something else again. Here again, he is the first witness of allegoricus, allegorice, allegorizare. But, in his use of allegory for the interpretation of the Bible, it is important to see that he is able to justify this by finding the word not in Paul, in general, but precisely in Marcion-Paul. He clearly does not feel able to allegorise generally, simply because Paul uses the word in Gal. 4. 24.

Aenigma is always used, with but one exception, in parallel with other terms, like parabola, allegoria, when it is used as a term of exegesis. Portendere has undergone a considerable change, and is used to indicate the future bent of the meaning of the scriptures.

The simplicitas complex is difficult to synthesize. Jerome was to feel the problem of the 'simplicity' of the scriptural style as an aesthetic term. Not so Tertullian. The times in which he lived were vastly different, of course, and Tertullian is not the man to concede the roughness of Scripture. Rather, he asserts that the curious turns of phrase, the difficult figures of Scripture are eleganter put; for him the simplicitas Scripturae is not a fault of style, but the directness of the truth.

Perhaps this is not so much a conviction, as it is a wish. Tertullian 
plays philosopher and rhetor, because he is forced to; because he was so well trained in literature, he could see all the difficulties of the literary argument. That scepticism, already present in the de testimonio animae, and always latent in scriptural discussions, attempted finally to find its certitude in the Montanist revelation. Incapable himself of simplicitas, Tertullian nonetheless insisted on the simplicitas of the Scripture; and he finally takes his refuge in a non-scriptural, simple solution to the problem of interpretation. 



\section{INDICES}

\section{IMPORTANT BIBLICAL TEXTS}

$\begin{array}{ll}\text { Genesis: } & \\ 1.1 & 9,80 \\ 1.2 & 12 \\ 1.26 & 49 \\ 2.7 & 11-13 \\ 2.21 & 62 \\ 2.21-24 & 33 \\ 2.24 & 149 \\ 3.7 & 92 \\ 3.9 & 135-136 \\ 3.21 & 92 \\ 21.2-9 & 149\end{array}$

Exodus:

20.3

49

Numeri :

12.8

$141,142,143,145$

Deuteronomium:

$25.4 \quad 149$

$28.37 \quad 141$

$32.39 \quad 100$

Iosue :

6.3-4 136

III Regum:

$10.1 \quad 141$

Psalmi:

$1.1 \quad 129-130,132$

$8.6 \quad 96$

$44.3 \mathrm{ff} . \quad 11$

$44.4150,15 \mathrm{I}$

$48.13,21 \quad 84$

$67.19 \quad 56-58$

$77.2 \quad 46-50$

$90.13 \quad 85$

$91.13 \quad 84$

117.22-23 143

$124.6 \quad 72$

Prouerbia:

$1.6 \quad 141$

$9.2 \quad 14-16,141$
Isaias:

$8.10 \quad 150$

11.1-2 73

$12.2 \quad 81$

$45.7 \quad 100$

$53.3 \quad 106$

53.3-5 10I-102

$53.4 \quad 45-46,101$

53.5106

Ezechiel:

37.1-14 155-156, 163

Ioel:

$3.1 \quad 80$

Matthaeus:

$5.17 \quad 124$

$7.7 \quad 131$

$7.18 \quad 73$

$8.17 \quad 45-46$

8.23-26 77

$10.16 \quad 86,167,168$

10.29-31 84

$13.24-30 \quad 69,70$

13.31-32 71

14.28-31 77

$27.9 \quad 53-54$

Marcus:

$4.3 \quad 48$

Lucas:

$5.36 \quad 46$

6.1-5 138

$6.20 \quad 50-52$

$6.43-44 \quad 73,100$

10.30-37 103

Iohannes:

$1.1,14 \quad 17 \mathrm{ff}$.

$5.2 \quad 99$

Actus Apostolorum:

2.17

80 
ad Romanos:
5.14
137,161
6.12-13
111
8.3
49

I ad Corinthios:

$1.27 \quad 9$

2.6-7 152

$5.5 \quad 106$

$6.20 \quad 61$

$7.39 \quad 13-14,62$

9.9-10 $\quad 149$

$10.4 \quad 80$

$10.6 \quad 161$

$13.12 \quad 142$

$15.33 \quad 9-11$

$15.35-38 \quad 72$

$15.36-38 \quad 93$

$15.53 \quad 93,96-97$

$15.55 \quad 59$

II ad Corinthios:

5.1

5.2-4 96-97

ad Galatas:

$\begin{array}{ll}3.27 & 94,95,96 \\ 4.21-31 & 149 \\ 4.22-26 & 161 \\ 4.23-24 & 54-56\end{array}$

4.24

$32-33,128,153,165,166$, 177

ad Ephesios:

$\begin{array}{ll}1.9-10 & 60-61 \\ 1.12 & 61 \\ 2.7 & 49 \\ 4.8 & 56-58 \\ 4.24 & 94 \\ 5.31-32 & 33,149 \\ 6.11-18 & 111 \\ 6.12 & 143\end{array}$

ad Philippenses:

$2.6 \quad 95$

$2.7 \quad 159,160$

$3.20 \quad 42-44$

ad Colossenses:

$1.17 \quad 61$

$3.10 \quad 94$

I ad Timotheum:

$1.1966,74$

$5.22 \quad 8-9$

II ad Timotheum:

$2.3 \quad 110$

ad Hebraeos:

2.6-9 96

\section{IMPORTANT TEXTS OF TERTULLIAN}

ad martyras:

1.4-5 85

apologeticum :

$18.2 \quad 81$

$21.10 \quad 18,27$

$21.12 \quad 72$

$21.17 \quad 18$

$47.2 \quad 64,78$

de testimonio animae:

$1.4 \quad 35-36,121$

de praescriptione haereticorum:

$13.2,3 \quad 18$

36.7-8 73 de spectaculis:

$3.3 \quad 129$

$18.3 \quad 86$

$20.1 \quad 129$

$29.4 \quad 171$

de oratione:

4.1-2 169

$11.2 \quad 32$

$29.4 \quad 88$

de baptismo:

$2.3 \quad 9$

3.29

$3.6 \quad 78$

$5.6 \quad 106$

$6.1 \quad 80$ 


$\begin{array}{ll}8.2 & 164 \\ 8.4 & 78 \\ 9.3 & 78 \\ 10.6 & 9 \\ 12.6-7 & 77-78 \\ 13.3 & 9 \\ 18.1 & 8-9\end{array}$

de paenitentia :

$12.5 \quad 106$

ad uxorem:

$\begin{array}{ll}1.6 .3 & 86 \\ 1.8 .4 & 9-11 \\ 2.3 .3 & 10\end{array}$

adu. Hermogenem:

$19.1 \quad 170$

$27.2 \quad 170$

$34.3 \quad 163$

adu. Marcionem:

1. 1.583

2. $4.2 \quad 73$

2. 9.1-2 11-13

2. $16.3 \quad 101$

2. $25.2 \quad 169$

2. $27.6 \quad 123$

3. $5.3 \quad 38,127,137,143,164$

3. 5.3-4 148

3. $7.6 \quad 92$

3. $8.1 \quad 87$

3. 12.495

3. $18.3 \quad 88$

3. $18.7 \quad 87$

3. $24.2 \quad 152$

3. $24.3 \quad 42-44$

4. $1.1 \quad 44-45$

4. $8.4 \quad 45-46$

4. $10.1 \quad 27$

4. 11.1171

4. $11.12 \quad 46-50$

4. $12.5 \quad 138$

4. $13.4 \quad 92$

4. $13.5 \quad 169$

4. $14.1 \quad 50-52$

4. $19.6 \quad 170$

4. 20.1-3 77, 78

4. 24.9-10 86

4. $24.10 \quad 28,164$

4. $24.11 \quad 32$

4. $25.1 \quad 143$

4. $35.14 \quad 143$

4. $40.2 \quad 53-54$

4. $40.6 \quad 92$
4. $42.8 \quad 129$

4. $43.7 \quad 170$

5. $1.2 \quad 75$

5. $3.11 \quad 61$

5. $4.8 \quad 54-56$

5. $6.1 \mathrm{ff} . \quad 162$

5. $7.5 \quad 61$

5. $8.5 \quad 56-58$

5. $10.16 \quad 58-59$

5. 12.1-3 96-97

5. $17.1 \quad 59-60$

5. $17.3 \quad 61$

5. 19.461

adu. Valentinianos:

$1.4 \quad 168$

$2.4 \quad 86,168$

3.1-5 168

$3.4 \quad 69$

de anima:

$2.6 \quad 89,99$

11.1-2 11

$32.8 \quad 84,88$

$47.2 \quad 80$

de came Christi :

$4.5 \quad 66$

13.1-4 27

de resurrectione mortuorum:

$2.11 \quad 168$

$20.7 \quad 170$

$26.10 \quad 80,94$

27.1-3 93

$28.1 \quad 67$

$28.5 \quad 171$

$29.1 \mathrm{ff} . \quad 155-156,163,170$

$30.1 \mathrm{ff} . \quad 163$

$42.12-13 \quad 97$

$56.5 \quad 72$

$57.12 \quad 94$

63.7-10 80-81, 122, 123, 156, 172

de corona :

8.2-5 174-175

$11.1-5 \quad 110$

scorpiace:

$1.5 \quad 168$

$1.8 \quad 15$

$6.11 \quad 15$

$7.1 \mathrm{ff} . \quad 14-16$

$7.5 \quad 16,150$

$11.4 \quad 144$ 


$$
11.4-7 \quad 28,157
$$

de idololatria:

$7.3 \quad 49$

$24.1 \quad 75$

$24.4 \quad 75,78,85,87-88$

de fuga :

10.2

95

adu. Praxean:

1.6-7 69

$5.1 \quad 134$

5.2-3 17-20

$5.4 \quad 17$

$8.5 \quad 72$

$13.4 \quad 157$

$14.6,7 \quad 142$

de uirginibus uelandis:

$1.5-6 \quad 71$

$1.6-7 \quad 130$

de monogamia:

11.10-11 13-14
$11.11 \quad 170$

de ieiunio:

$3.3 \quad 105$

de pudicitia:

4.1-2 20-26

$6.6 \quad 21$

$6.15-16 \quad 78$

$6.16 \quad 91$

$9.1 \quad 26$

9.1-3 78

$9.3 \quad 171$

$9.12 \quad 171$

9.12-13 105

$\begin{array}{ll}9.22 & 123\end{array}$

$13.19-20 \quad 75$

$16.12 \quad 68$

$16.17 \quad 21$

$18.7 \quad 21$

19.1-2 22

$19.5 \quad 26$

adu. Iudaeos:

$1.1 \quad 134$

$5.14 \quad 78$

\section{LATIN WORDS}

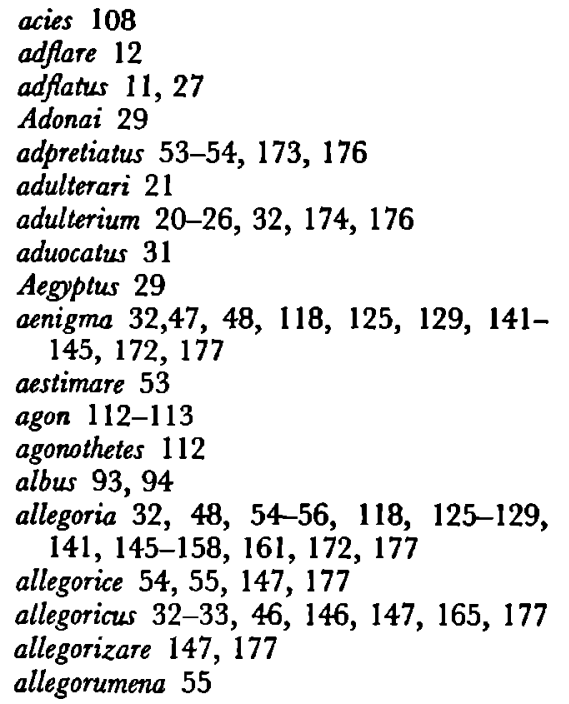

alleluia 28

amartia 8-9, 62

ambiguitas 122, 132, 142

amen 28

amentia 33

angelus 29, 31

antithesis 44

anulus 90, 94

apostolus 29

aqua $78-81$

argilla 114

arma 111-112

Babylon 29

bibere 79

cadauer 33

calcare 85

canis 84

caro et sanguis 29,173

carnalia 33 
castra 110

certamen 112-113

ceruus 83

charismata 56-58

chelidonia 83

chrisma 30

Christianus 29, 33

Chrislus 29, 30, 33

clausula 139

cohaerentia 139

colloquia 9-10

color 138, 139

conculcare 85

confessio 35

confiteri 35

confabulatio 9-11, 62

congressio 108, 109

congressus 9-11, 62, 109

conloquia 10

contentio $58-59,175,136$

controuersia 139

conuersatio 43

cor 30,173

corona 112,113

corporalia 33

cuneus 109

curare 101, 106

curatio 107

datum 56-58, 175, 176

debitum 30

delinquentia 9

delictum 8-9, 11, 21, 22, 29, 30, 62

despoliare 98

destillare 80,81

dictamnum 82

dimicare 108, 109

disciplina 32

dissimulare 122

documentum 158

domus 28, 97

donatiuum $56-58$

donum 57,58

dormire $13-14,62,177$

dormitio 14

drachma 28

ebibere 79

ecstasis $33,62,136,174$

edictum 20, 21, 50

edissere 47

effundere $66,80 \mathrm{ff} ., 174,177$

egenus 51-52

eleganter 28, 36, 56, 58, 140, 177

elementa 30 elogium 20, 24, 29

eloqui 47

enubilare 156

episcopus episcoporum 176

epistates 112

euersio $13 \mathrm{ff}$.

exemplum 158

exolescere 103

exomologesis 27, 34, 174

femine 30

figulare 114

figulus 114

figura $29,30,32,83,116,125,129,144$, $158-164,165,172,177$

figuraliter 158-164, 177

figurare 163

figurate 86, 158-164, 172

figuratio 160

filius 14-16

flii hominum $56,57,176$

fingere 114,158

falus 11-12

fons 72, 79, 80

fornicarius 22

fornicatio $20-26,32,62,173,174,176$

fornicator 21-22

fructus 71

gloria 14-15

gradus 108, 109

gratia 27

gubernaculum 75, 76

haeresis 33

haurire 81

honorare 53

hostia 15

hyperbaton 140

ille 49, 176

imago 144

incidere 104

induere 93, 94-96, 177

in initio 17

inolescere 69

instaurare 61

instrumentum 33, 44-45, 120

interpretari $54,56,140$

interpretatio 51, 140

inundare 81,177

iugulare 14-15

linea 108, 109

luctari 111 
luctatio 111

lupues 88

lux 30

mactare 15

mammona 29

medicator 101, 106

medicina 102

medicus 15, 99-107

mendicus 50-52, 61

miles 110-11

militia 107, 110, 111

mna 28

moecha 22

moechari 21,22

moechia 20-26, 32, 173, 174, 176

moechus 22

mulier 30-31, 174

municipatus 42-44, 62

mysteria 162

mystice 162

\section{nauclerus 75}

naufragium 74, 75

naufragus $74,75,76$

nauicula $77-78$

nauis (ecclesiae) $75,77-78$

nomen $94,110,111$

nubilum 129, 154, 155, 156

nuntius 29

obsauritas 132

oikonomia 34

oleaster 73

opusculum 20, 23

ostensiones 55

paenitentia 34,173

paenitere 34

paganus 110

palaestra 112

parabola 32, 46-50, 122, 142, 144, 175,

176,177

paracletus 31

paratura 44

pauper 51

pax 27

peccatum 9

phoenix 84

pisciculi 87

planca 76

plasmare 113, 114

plasmator 72, 114

plastica 115

politeuma 42-44, 62 politia 42,62

pompa 35

portare 45-46, 176

portendere $33,54,55,118,129,164-166$, 172, 177

portus 75

potare 66, 78-79, 80, 177

praesperare 61

in primordio 17

in principio 17

problemata $47,50,173,176$

procella 74,76

propositio 47

proselytus 31

pullulare 69

quadrans 28

quaestio $47,50,142$

radius 72

radix 71

ratio 17

recapitulare 60-61

recensere $60-61$

reciprocare 60

recolligere 60

redigere 60

regula 122, 133

remediator 100, 101, 106

restaurare 61

reuclare 152

rigare $64,65,66,78-79$

sacramentum $110,111,161,162$

salus $27,106-107$

salutificator 107

saluator 107

saluus 106-107

Samaria 29

sanare 106

sanus 106

sapientia 14-17

Satanas 29

sator 72

scamma 112

scriplum et uoluntas 138

semen 70, 71, 72

sensus publicus 121

sermo $17-20,26,27,62,173,175$

serpens $31,85-87$

significare 55, 166, 172

silua $68-69$

similitudo 46-50, 176

simplex 32, 129, 166-171

simplicitas $28,118,128,129,148,162-$ 


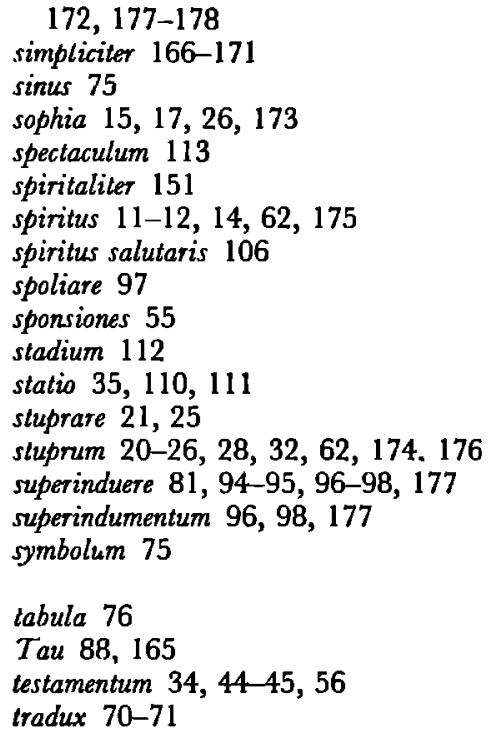

transgressio 110

typicus 161

typus 146, 158, 161, 162

unetio 30

uniuira 35

usus $3,13,20,22,37$

uxor 30

uae 29

uas 31,114

uel $37,58-59$

uerbum 17-20, 62

uestire 89, 90, 95

uestis 90

uia 31-32

uictima 16

uicloria 58-59, 175, 176

uirgo 30

uzsio 144

uita 14-15

xyslarches 112 




\section{STELLINGEN}

Het is zeer waarschijnlijk dat Tertullianus aanzienlijke gedeelten van de Schrift in latijnse vertaling(en) kende.

\section{II}

Wil men zich rekenschap geven van Tertullianus' gebruik van verbum in plaats van sermo in apol., de praescr., adv. Iud. en de carn., dan dient men rekening te houden, niet alleen met de ontwikkeling van Tertullianus, maar ook met de karakteristieke aanpassing van zijn taal aan die van zijn tegenstander of lezers. Dit geldt in het bijzonder voor de carn., waarin René Braun het gebruik van verbum ten onrechte wilde verantwoorden door een vroegere datering (zie Deus Christianorum, p. 268-269).

\section{III}

Het is veelzeggend, dat Tertullianus de Christus medicus-beeldspraak in adv. Marc. niet uitwerkt, hoewel alle elementen voor zulk een uitwerking aanwezig zijn.

\section{IV}

Het gebruik van de tegenstelling terrena - caelestia, die bij Tertullianus dikwijls voorkomt, werpt licht op de latere liturgische formule.

\section{V}

Het citaat Luc. 10.21, 'Gratias enim, inquit, ago et confiteor, domine caeli...', dat wij aantreffen in adv. Marc. 4. 25.1 houdt geen glosse van Tertullianus in, waarin deze confiteor met gratias ago zou willen verklaren. Het onafhankelijke getuigenis van Epiphanius, Panarion haer. 42. 11.6, schol. 22 (K. Holl, GCS 31, p. 110, 1. 9-11), toont aan, dat in de tekst van Marcion $\varepsilon \dot{\chi} \chi \alpha \varrho \iota \tau \tau \bar{\omega}$ voorkwam. Men zou dit dientengevolge in de apparatus criticus van Luc. 10.21 moeten noteren. 


\section{VI}

Tertullianus' gebruik van allegorese en het gebruik dat hij maakt van Gal. 4.24 dient men te zien tegen de achtergrond van gnostische en marcionitische stromingen.

\section{VII}

Evenzeer als een kritische uitgave zou een geannoteerde vertaling van adv. Marcionem van Tertullianus nuttig zijn, gezien het belang van dit werk voor onze kennis, niet alleen van het Nieuwe Testament en zijn ontwikkeling en exegese, maar ook van de godsdienstige en filosofische stromingen van de latere tweede eeuw.

\section{VIII}

Een register van plaatsen uit de $\mathrm{H}$. Schrift dat alleen aandacht besteedt aan de directe citaten geeft een inadequaat beeld van het Schriftgebruik bij Tertullianus.

\section{IX}

Het gebruik van beeldspraak bij Ignatius van Antiochië en Tertullianus staat in scherpe onderlinge tegenstelling, hoewel beiden vertegenwoordigers zijn van de 'asianistische' stijl.

\section{$\mathrm{X}$}

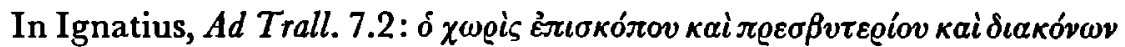
$\pi \varrho a ́ \sigma \sigma \omega v \tau \iota$ sluit Th. Gamelot O.P. zich terecht aan bij de lezing van Lightfoot en Funk ( $\delta \iota \alpha \kappa o ́ v \omega \nu)$, en verkiest deze boven die van Zahn en Bauer ( $\left.\delta_{\iota} \alpha \kappa o ́ v o v\right)$, welke door Bihlmeyer in zijn uitgave overgenomen is. Cf. Th. Camelot, Sources chrétiennes no. 10, p. 116; K. Bihlmeyer, Die apostolischen Väter, p. 94.

\section{XI}

De opvatting dat Lucretius in de twee passages de rer. nat. 5. 1430-1435, 1448-1457 'has committed himself to the whole theory of progress', zoals Tenney Frank (Life and Literature in the Roman Republic, p. 241), Dean Inge en anderen hebben gedacht, is onwaarschijnlijk, gezien het hele wereldbeeld van Lucretius en vroegere passages van de rer. nat., die licht werpen op deze twee gedeelten. 


\section{XII}

De oraties in de $\mathbf{H}$. Mis vervullen elk hun eigen functionele rol in de opbouw van de liturgische handeling. Ze zijn onderling niet uitwisselbaar.

\section{XIII}

Voor het opstellen van instrumenta studiorum en voor taal- en stijlanalyses lijkt de computertechniek voortaan onontbeerlijk geworden. 
Stellingen behorende bij T. P. O'Malley,

Tertullian and the Bible

Nijmegen, 1967 

